\title{
The Birthday Letters Myth
}

\author{
By
}

Andrew Derek Armitage

\begin{abstract}
A thesis
submitted to the Victoria University of Wellington in fulfilment of the requirements for the degree of Doctor of Philosophy in English
\end{abstract}

Victoria University of Wellington

2010 


\begin{abstract}
Ted Hughes's Birthday Letters (1998) has, for the most part, been judged in terms of its autobiographical content rather than for its poetic achievement. The poems are addressed to Hughes's first wife Sylvia Plath, who committed suicide in 1963 shortly after they separated. The poems describe their relationship and deal with the aftermath of her suicide and Hughes's role in managing and promoting her writings, in many of which he was characterised as a villain. Hughes has been criticised for his subjective treatment of these events in Birthday Letters. Furthermore, the drama of the poems takes place in an apparently fatalistic universe which has led to accusations that Hughes uses fatalism in order to create a deterministic explanation for Plath's suicide and absolve himself.
\end{abstract}

In The Birthday Letters Myth I will be arguing that Hughes's mythopoeia in Birthday Letters is part of his overtly subjective challenge to the discourses that have hitherto provided the "story" of his life. In Birthday Letters, there are two versions of Hughes: the younger Hughes who is character involved in the drama, and the older Hughes, looking back on his life, interpreting 'omens' and 'portents' and creating a meaningful narrative from the chaos. By his own method, Hughes highlights the subjectivity and retrospective determinism of those narratives (or 'myths') about his life that often uncritically adopt the dramatic dialectic of 'victim' and 'villain' in Plath's poems.

In Birthday Letters, Hughes adopts the symbols and drama from Plath's writings in order to create his own dramatic "myth" that resists contamination from the other discourses that have perpetuated the drama within her poems. The underlying myth of Birthday Letters is the shamanic myth of Orpheus and Eurydice. Hughes believed the role of the poet and that of the shaman were analogous and in Birthday Letters, as Orpheus, he goes on an imaginary journey to recover his private assumptions and conclusions about his relationship with Plath. In doing so, he achieves a redemptive, cathartic healing image for himself and the reader. 


\section{Acknowledgements}

I am extremely grateful for the support, criticism and encouragement from my supervisors Anna Jackson and Harry Ricketts throughout the writing of this thesis. They have been a great help in helping me to develop and formulate my ideas coherently.

Thank you to Victoria University of Wellington for providing me with funding towards my trip to the Ted Hughes literary archives in Emory, Atlanta in 2005, and more recently, in providing me with a completion scholarship in the last months of writing.

I am also grateful for assistance from a large number of scholars who have provided me with encouragement and support, helped me locate articles, radio broadcasts and books, and so on, during the completion of this thesis. I am particularly indebted to Claas Kazzer, Ann Skea, and the late Diane Middlebrook.

Thanks to the staff at Emory University for their assistance in my research, and to Mrs Carol Hughes and Seamus Heaney for permissions to copy materials from the archives.

Thanks also to Greg Martin and my partner Bec Edwards who read earlier drafts of this thesis and provided helpful feedback and advice. 


\section{Contents}

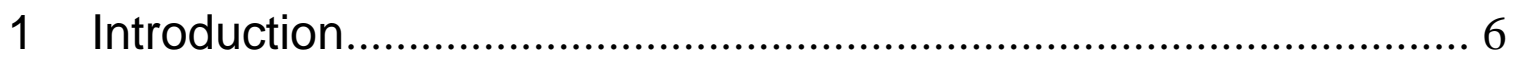

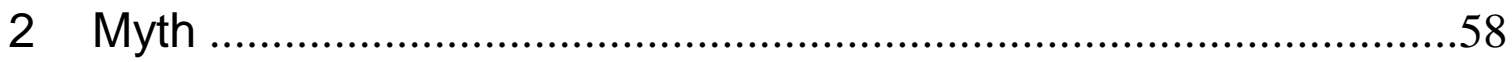

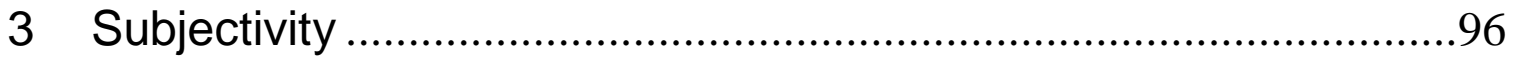

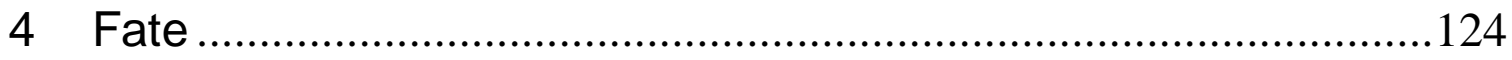

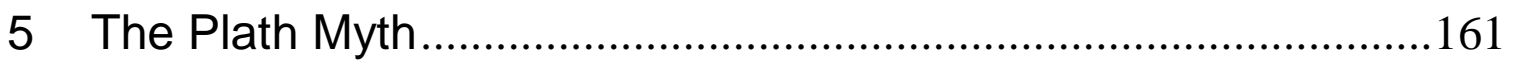

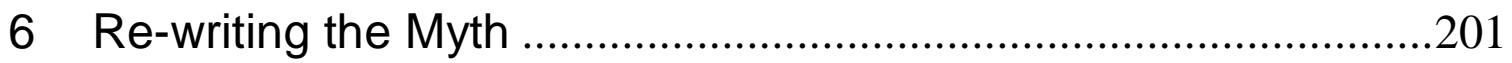

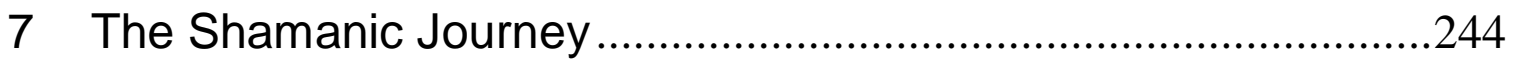

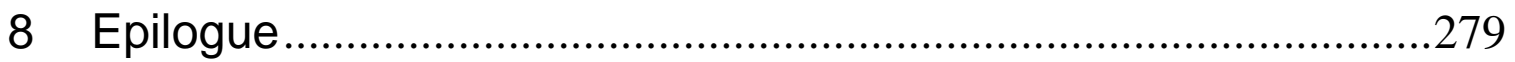

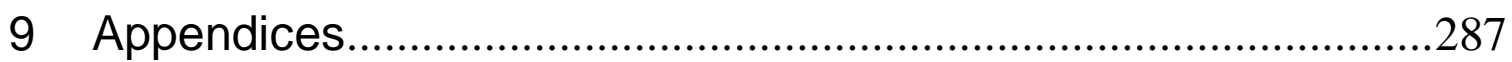

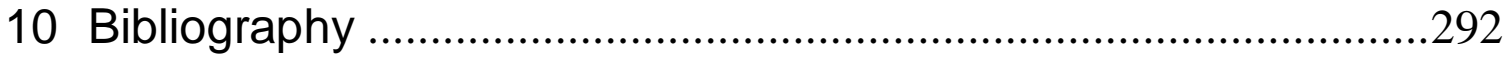




\section{Introduction}

When Birthday Letters first appeared in 1998, the majority of the book's reviewers focussed on the autobiographical aspect of the poems. ${ }^{1}$ This is not surprising, given Hughes's silence about his marriage in the preceding years. However, it has also meant that Birthday Letters has often been judged in terms of its autobiographical content rather than its poetic achievement. Katha Pollitt was one of Birthday Letters' most forceful critics. In her New York Times review, she suggested that getting to the 'truth' of the Birthday Letters story was the reader's objective:

Inevitably, given the claims that these poems set the record straight, the question of truth arises. Plath's letters and journals present her as struggling hard to be a dutiful literary wife - typing her husband's poems, promoting his work, rejoicing in his success and also resenting it. The difficulties - practical, social and, most of all, psychological - of being a woman of burning literary ambition preoccupied her from earliest childhood. None of this struggle is reflected in Birthday Letters. Nor does Hughes engage with the fury that suffuses Plath's late poems - and with which many women have identified - about being stuck at home with the babies and the housework and the boring neighbours. ${ }^{2}$

\footnotetext{
${ }^{1}$ For reviews of Birthday Letters see: Alvarez, Al. The New Yorker. 7 February 1998; Blakely, Dianne. 'The Birthday Letters by Ted Hughes'. Antioch Review (Yellow Springs, OH). Winter 1999. 57:1. 117; Churchill, Sarah. 'Secrets and Lies: Plath, Privacy, Publication and Ted Hughes' Birthday Letters'. Contemporary Literature. Vol. 42, 1. 102; Fenton, James. New York Review of Books. 5 March 1998; Glover, Michael. New Statesman. 30 January 1998; Grossman, Judith. 'Broken Silence'. New England Review. Fall 1998. 154-60; McManus, James. 'Black Magic'. The American Poetry Review. Oct/Nov. 1998; 27. 6; Morgan, Robyn. Newsweek. 2 February 1998; Motion, Andrew. The Times. 17 January 1998; Pollitt, Katha. 'Peering Into the Bell Jar'. The New York Times. 1 March 1998; Sen, Sudeep. 'Birthday Letters'. World Literature Today. Summer 1998. 72-3; Warn, Emily. Seattle Weekly. 5 March 1998; Whittington-Egan, Richard. The Life After Death of Sylvia Plath. Contemporary Review. May 1998; 272, 1588; Williamson, Alan. 'A Marriage Between Writers: Birthday Letters as Memoir and as Poetry.' The American Poetry Review. Sept/Oct 1998; 27, 5; Wood, James. 'Muck Funnel: Birthday Letters by Ted Hughes'. The New Republic. Mar 30, 199; Wright, Carolyne. 'The Poet's Inquest' The American Scholar. Summer 1998; 67. 3.

${ }^{2}$ Pollitt, Katha. 'Peering Into the Bell Jar'. The New York Times. 1 March 1998. Hereafter referred to as 'Peering into the Bell Jar'.
} 
In her analysis, Pollitt overlooks poems such as 'The God' and 'Suttee', in which Hughes depicts Plath as "a woman of burning literary ambition", because these poems do not contribute to her reading of Hughes as "the most notorious literary spouse in history". In Pollitt's view, Birthday Letters is a public relations exercise and an attempt to divert attention from Hughes's responsibility for Plath's suicide:

Here, we are to believe is the Truth About Sylvia, which can be summarised as: she was beautiful, brilliant, violent, crazy, doomed; I loved her, I did my best to make her happy but she was obsessed with her dead father, and it killed her... Incident after incident makes the same point: she was the sick one, I was the “nurse and protector”. I didn't kill her - poetry, Fate, her obsession with her dead father killed her. The more Hughes insists on his own good intentions and the inevitability of Plath's suicide, the less convincing he becomes. One starts to wonder what it means to blame a suicide on Fate, on a father who died, after all, when Plath was 8 years old, or on "fixed stars". Inadequate as it is to see Plath's life in wholly sociological, political terms - the plight of a young female genius in the pre-feminist era - it makes more sense than astrology. ${ }^{3}$

For Pollitt, the "astrology" and "Fate" in Birthday Letters are ways for Hughes to depict himself and Plath in a universe in which human will is subjected to, and overwhelmed by, some cosmic force, which enables him to avoid the accusations of those who have suggested his actions drove Plath to suicide. Pollitt's reading indicates how the story in Birthday Letters exists within a number of discourses that each vie for status as the 'true version'. For Pollitt, Hughes's subjectivity and his intimate access to Plath do not make him a valuable witness who can tell us 'what really happened' because his need to exonerate himself damages the veracity of his account.

Against Birthday Letters, Pollitt offers another account of Hughes's and Plath's lives that she believes is crucially missing from Birthday Letters but can be constructed from "Plath's letters and journals". However, Pollitt does not acknowledge the

\footnotetext{
3 'Peering into the Bell Jar'.
} 
problematic subjectivity of Plath's writings, their internal contradictions or their inconsistencies. Although Pollitt acknowledges the "inadequacy" of her own version of Plath's story as "the plight of a young female genius in the pre-feminist era", she appeals to the reader's reason to suggest that her version of this story "makes more sense than astrology".

James Wood was another reviewer concerned with the 'truth' of the Birthday Letters story. Like Pollitt, he criticises Hughes's use of Fate and astrology in the poems, but on aesthetic, rather than ethical, grounds. For Wood, the problem with Hughes's mythopoeia in Birthday Letters is that it denies readers access to the 'real' and 'particular' Hughes and Plath:

The aura of pre-destination is certainly this book's strongest texture. The poems find different ways to accuse destiny... Certain readers, noting Hughes's fond marriage to Fate, to bravuras of pre-destination, have charged him with selfabsolution. But Hughes was not responsible for Plath's death, and so he has no need to absolve himself. That is not the problem here. His pagan doom, the suckling gods and bloody crypts, do not absolve, but dissolve. A real particular Plath disappears, and a real, particular Hughes disappears too, drowned in a sud of images that are borrowed from their own poetry, or borrowed from the most familiar dirty magics. Particularity is secular, and these dark poems show us why. ${ }^{4}$

Wood suggests that a "secular" poetic would have more closely resembled the 'truth' of Birthday Letters story than the mythic drama that frames the narrative. Wood points out that "it is not Fate that stages these bitter dramas, but the poet, who chooses to write them up", 5 as though he feels it is necessary to highlight to the book's readers that Hughes is imposing an imaginative order on the story.

\footnotetext{
${ }^{4}$ Wood, James. 'Muck Funnel: Birthday Letters by Ted Hughes'. The New Republic. Mar 30, 1998; 218 , 13. 30. Hereafter referred to as 'Muck Funnel'.

5 'Muck Funnel'. 30.
} 
Pollitt's and Wood's objections to the mythopoeic treatment of biographical events in Birthday Letters are characteristic of contemporary critical responses to the sequence, and it is this form of response I will be addressing in the chapters that follow. I will be arguing that the mythopoeia in Birthday Letters is part of the sequence's subject matter, rather than simply a formal aspect of the poems. Hughes's overt mythopoeia in Birthday Letters should be seen as an advertisement of the subjective and imaginative nature of the poems rather than a strategy to avoid or conceal 'truth'. Birthday Letters should be approached, understood and judged as a subjective work of art rather than as an objective autobiographical record. The poems are subjective in that they involve a selection and presentation of events by a single author and are driven towards personal assumptions and conclusions. In this sense, Birthday Letters is no different to Plath's writings, or the secondary interpretations of these writings by her readers. However, in acknowledging this aspect of the Birthday Letters story, Hughes highlights the impossibility of writing objectively about himself and Plath. He also draws attention to the subjective nature of Plath's own writings and of the discourses, or 'myths', that surround and give meaning and context to her (and his) life and writings.

From the opening poem of Birthday Letters, Hughes foregrounds the fallibility of his vision in the poems. These are not so much an historical record as a loose collection of subjectively and imaginatively ordered experiences. These poems are usually provoked by, or refer back to, events described in Plath's writings. Hughes engages directly with Plath's words, symbols and drama in order to contend for the 'truth' of the events (both real and imaginary) that Plath describes. In Birthday Letters, Hughes has been prompted into dialogue by the voice of Plath's writings, and the two poets struggle for possession of the meaning and significances of their shared experiences. In this sense, Birthday Letters can be seen as an interpretation, or reading, of Plath's writings in dramatic terms. But Hughes also extends the vision of a relationship in Plath's subjective drama to include his own experiences by introducing new symbols, or describing other events, that do not appear in Plath's writings, and do not rely upon her writings for their meaning and significance. 
In Poetry in the Making (1967), a guide Hughes wrote for aspiring young writers, he spoke of the subjective nature of human experience and the problem of autobiographical writing:

Most of us just retain a vague impression of an event, with one or two details that affected us directly, and when we ask someone else to give their account of the same event it is highly probable that their memory will contradict ours. This could mean we both saw different aspects of the event and are both, in our way, right. But it is certain that we both saw almost nothing and made our judgement of all the facts after only seeing one or two of them. How would you like to be condemned by a jury who when they go into the jury room remember about as much of your case as you do of the lessons you had last week ${ }^{6}$

In this courtroom analogy, Hughes anticipates the way in which he would be judged in the Plath biographies that began to emerge in the early 70s when feminists interpreted the archetypal drama in Plath's poems (based around a dialectic of victim and aggressor) as a description of the suffering of women in patriarchal society. In this feminist reading of Plath's work and life, Hughes is reduced to a caricature of all that is wrong with patriarchal society and his struggle in Birthday Letters, to free himself from the narratives of the feminist movement, mirrors this reading of Plath's poems as her struggle to free herself from the narratives of patriarchy. In an autobiographical sense, both Ariel and Birthday Letters offer partisan visions of a marriage in which the speaker is trapped and limited by his or her spouse. However, the subjective manner of these writings means that if they contradict one another, this is not to say that one version of events is false, but, as Hughes wrote in Poetry in the Making, that the authors "both saw different aspects of the event and are both, in [their own] way, right."7

In the chapters that follow, I will be arguing that, in Birthday Letters, Hughes revisits a story that has become a 'myth' in the sense that the symbols and drama within

\footnotetext{
${ }^{6}$ Hughes, Ted. Poetry in the Making. London: Faber and Faber. 1967. 88. Hereafter referred to as 'Poetry in the Making'.

7 'Poetry in the Making'. 88.
} 
the story have become more significant, in cultural terms, than the private historical individuals within it. There is much at stake, culturally, politically, and ethically, in the way we interpret the significance of the characters' actions in this story because this is one of the stories we have chosen to help us explain and make sense of our relationships in the twentieth century. Over the years, many accounts appeared that crudely reduced the complexity of Hughes's and Plath's identities and their relationship in order to fit those stories. Hughes dismissed these crude interpretations of his life as "fantasies" and suggested that in such readings the readers' inner needs were being projected onto the symbols and drama of Plath's writings. ${ }^{8}$ Nevertheless, he was distressed by the way these narratives initiated erroneous statements about his and Plath's historical lives which, once printed and multiplied, obtained the status of objective fact. Hughes felt his life was being repeatedly misrepresented, sometimes wilfully or sometimes because a writer's assumptions and opinions had become confused with the facts. He believed 'the facts of his life' were being distorted, or controlled and manipulated by an external agency that he could not challenge or engage with in any meaningful way without exposing his private life to further scrutiny. Rather than 'owning' his story, Hughes felt he and Plath were 'owned' by the story that dramatically represented the struggle of the feminist movement. With this in mind, we can see his mythopoeia in Birthday Letters as an ironic form of address in which he contends with the "fantasies" that have taken control of his life. In re-framing this drama and symbolism, Hughes unsettles the reader's confidence in determining fact from fiction, and forces the reader to accept the subjectivity of any 'truths' relating to his or Plath's life. However, it would be wrong to understand the mythopoeia of Birthday Letters as wholly ironic. Hughes saw Plath's poems as an interpretation of her private experiences and personal history in mythic terms. He believed that Plath's poems were typical of all great works of art in that their drama and symbols constellated around universally understood archetypal experiences that healed the artist and his or her audience.

\footnotetext{
${ }^{8}$ Letter from Ted Hughes to Al Alvarez quoted in: Malcolm, Janet. The Silent Woman: Sylvia Plath and Ted Hughes. New York: Alfred A. Knopf, 1994. 128. Hereafter referred to as 'The Silent Woman'.
} 
In addition to contending with the characterisation of Hughes in the drama of Plath's poems, Birthday Letters tells the story of Hughes's relationship with Plath's writings, and the reception of Plath's writings following her suicide. As Plath's literary executor and editor, Hughes faced a difficult role in promoting the poems that criticised him. To understand the complications Hughes faced in this role and responded to in Birthday Letters, some biographical background is necessary. What follows is a summary of Hughes's relationship with Plath and her writings and a survey of the relevant literary history, as a contextual basis for the consideration of Birthday Letters in the following chapters.

Hughes met Plath met on 25 February 1956, at a party to launch St Boltoph's Review, a Cambridge literary magazine that he printed with friends to publish their poems. He had graduated from Cambridge University in July 1954 and was staying in a borrowed flat in London during the week, returning to Cambridge to visit friends at weekends. Plath had recently arrived in Cambridge from America as an undergraduate on a Fulbright Scholarship. She had already published short stories and poems in a number of literary journals, and several months prior to meeting Hughes at the party, she had read a scathing review of her poems by Hughes and his friends in the Cambridge journal Broadsheet (January 1956). As Dianne Middlebrook explains:

To Plath's immense surprise, her poetry was immediately singled out for a sneering review in [a] student publication called Broadsheet. Plath had unknowingly wandered onto a battlefield in a collegiate poetry war and turned out to be on the wrong side; the reviewer dismissed Plath's style as "quaint and eclectic artfulness", then added, "My better half tells me 'Fraud, fraud', but I will not say so; who am I to know how beautiful she may be." The mimeographed pages of Broadsheet looked amateurish, but they were widely read and discussed. As Plath wrote to her mother, "there are 10 critics to each poem ... using clever 
devastating turns of phrase to show off their own brilliance...[But] the deep parts of me are not affected, and I cheerfully go on writing." 9

Plath wanted to meet her reviewers face-to-face at the St Boltoph's party. She had also read and memorised several poems in the St Boltoph's magazine by Hughes and their mutual friend Lucas Myers. Plath's interest in and attraction to Hughes was due, in part, to her admiration for his poetry and after meeting him at the party she described him in her journals as "The one man in the room who was as big as his poems". ${ }^{10}$ Within a few months of their first meeting, Hughes and Plath were married, on 16 June - Bloomsday 1956, and like their courtship, their marriage was characterised by a firm commitment to their writing, which would prove stronger than their commitment to each other.

Hughes was the first to find literary success with his first collection of poems, The Hawk in the Rain, which received considerable critical acclaim and won a Harper publication prize. After Plath finished her degree in the summer of 1957, he and Plath spent an unsettled year teaching in America, before returning to England and, after borrowing money from their parents, buying a house at Court Green, in North Tawton, Devon. After their teaching experiences in America, they had both decided to try and make a living from their writing. In 1959, Hughes won the Galbraith Prize, which netted \$5000, and in 1960, his second book Lupercal also met with critical acclaim, winning the Somerset Maugham prize and the Hawthornden Prize. That year, Plath published her first book of poems The Colossus which received modest critical approval but which did not have the same impact as Hughes's books. As a figure on the literary landscape Plath remained, for now, in his shadow. That same year, their first child, a daughter, Frieda Rebecca was born. In January 1962, Hughes and Plath had a second child, Nicholas. Shortly after the birth of their son, Hughes embarked on an affair with Assia Wevill, a woman the Hugheses had met and befriended when she and her husband, the poet David Wevill, had taken over the lease on their London flat. Learning of the affair in July 1962,

\footnotetext{
${ }^{9}$ Middlebrook, Diane. 'Hughes, Plath, and the Three Caryatids'. Fixed Stars Govern a Life: Transforming Poetics and Memory with Emory's Ted Hughes Archive. Atlanta GA. The Academic Exchange. 2006. 49.

${ }^{10}$ Kukil, Karen. Ed. The Journals of Sylvia Plath 1950-1962. London: Faber and Faber, 2000. 212. Hereafter referred to as 'The Journals'.
} 
Plath insisted he move out of their Devon home and he stayed with various friends in London. Over the next seven months, during this period of their separation, Plath wrote most of the poems that would become Ariel, the collection of poems that would 'make her name' as she said in a letter to her mother. On 12 December, feeling isolated with her two young children in rural Devonshire, Plath left Court Green and also moved to London, renting a flat at 23 Fitzroy Road, which bore a blue heritage plaque to inform that Yeats had previously lived there.

The London winter of 1962-63, known as 'The Big Freeze', was the coldest winter in the United Kingdom for two hundred years, and one of the coldest ever on record. Rivers, such as the Thames, froze, as did the water pipes in people's homes. Electricity was rationed and there was heavy snowfall all over the country. During this bitter cold-spell Plath was suffering from a cold, insomnia, and depression as she struggled to care for herself and two young children while she dealt with the aftermath of her separation from Hughes. Although Plath had arranged for a telephone to be installed in her flat, the severity of the winter conditions meant it was delayed and she was forced to rely on a public telephone to make any calls, adding to her isolation. In January 1963, her semi-autobiographical novel The Bell Jar was published under the pseudonym 'Victoria Lucas'. The novel provided a fictionalised account of Plath's nervous breakdown and suicide attempt of 1953, and the electro-convulsive treatment she underwent subsequently. On the early morning of Monday 11 February 1963, suffering from depression, fearing the return of her earlier mental illness and having to undergo further electro-convulsive treatment, she sealed the bedroom doors of her children and committed suicide by gassing herself in the kitchen.

At the time of Plath's suicide, although she and Hughes had separated, they were still married. Because she had left no will, in addition to taking over the care of their children, Frieda and Nicholas, Hughes became Plath's literary executor. Among her papers, private journals, and letters, Hughes found a black folder containing a typescript of poems entitled Ariel. He also found a second smaller bundle of later poems written in 1963, some composed only a few days before her death. Hughes was startled by the 
poems, many of which Plath had not shown him. He would, no doubt, have felt the stings in the poems he discovered, many of which attacked him, but he also recognised their originality and importance, and felt an obligation to Plath to publish the poems. As Diane Middlebrook explains:

Though Ariel was dedicated to her children, it was aimed at Hughes... Hughes apparently did not resent the militant rivalry he found in Ariel. He was astonished by the artistic mastery in these and the handful of other poems he found among her papers, written since she moved to London, most of which he had never seen before. Poets who visited him recall that he kept the typescripts lying on a table, and would read them aloud to guests. He spoke passionately about his conviction that Plath's poetry had achieved a true greatness: "no other woman poet except Emily Dickinson can begin to be compared with her." His admiration never abated. $^{11}$

Although Hughes felt an obligation to Plath to publish Ariel, he re-arranged the sequence by removing several poems (that had not already been published) in which he felt himself or others were attacked too openly, and by replacing these with other poems Plath had not selected for Ariel. In his 1971 essay 'Publishing Sylvia Plath', he described the process:

I was anxious that the collection should not falter in any way, and that her work should be recognised, yet I saw quite plainly that very few knew what to make of it. And I know what a person becomes in writing a review. So I had already started rearranging the collection, cutting out some pieces that looked as if they might let in some facile attacker, cutting out one or two of the more openly vicious ones, and a couple of others that I thought might conceivably seem repetitive in tone and form. Two or three I simply lost for a while in the general fog of those days. I would have cut out 'Daddy' if I'd been in time (there are

\footnotetext{
${ }^{11}$ Middlebrook, Diane. Her Husband: Ted Hughes and Sylvia Plath: A Marriage. London: Little Brown, 2004. 218. Hereafter referred to as 'Her Husband'.
} 
quite a few things more important than giving the world great poems). I would have cut out others if I'd thought they would ever be decoded. I also kept out one or two that were aimed too nakedly (I kept them out in vain as it happened. They were known and their work is now done. $)^{12}$

As well as adding Plath's last poems to the sequence, Hughes inserted "two preAriel poems", 'Little Fugue' and 'The Hanging Man', which he felt 'belonged” in Ariel. 'Little Fugue' is a poem in which Plath appears to address her father, Otto Plath, who died when she was eight-years-old. In Hughes's view, Plath's unresolved grief for her father was the psychological crisis that Ariel had been created to heal. The other preAriel poem, 'The Hanging Man', according to Hughes, “describes with only thin disguise the experience that made Ariel possible" ${ }^{\prime 13}$ which was Plath's electro-convulsive treatment after her earlier suicide attempt of 1953. As we will see, Hughes's rearrangement of Ariel is the earliest indication of his reading of Plath's life and writings ${ }^{14}$ in his critical writings about Plath, and in the dramatic reading he gives of her life and writings in Birthday Letters.

On 11 March 1965, Hughes published this re-arranged selection of Ariel. ${ }^{15}$ The book was instantly an overwhelming critical and commercial success and before long Plath's literary fame would eclipse his own. Al Alvarez, the poetry editor at The Observer, an early promoter of both Hughes's and Plath's poetry, was the most influential critic in terms of the early reception of Plath's poetry. Alvarez was also a close friend of Hughes and Plath and following her suicide he accompanied Hughes to identify her body at the undertakers and to the coroner's inquest. In his Observer review of Ariel, 'Poetry in Extremis' (1965), Alvarez argued that Plath's poems were too original to be linked to the "fad" of confessional poetry. He described the poems as a risky "balancing act" between "colloquial sanity" and "images that open up the depths" and pointed out that the autobiographical elements in the poems were not crudely

\footnotetext{
${ }^{12}$ Hughes, Ted. 'Publishing Sylvia Plath'. [1971] Winter Pollen: Occasional Prose. London: Faber, 1994. 166-7. Hereafter referred to as 'Winter Pollen'.

13 'Winter Pollen'. 167.

${ }^{14}$ Hughes' and Plath's selections for Ariel are listed together for comparison in Appendix 5

${ }^{15}$ Ariel was published in the U.K. in 1965 and in the U.S. in 1966.
} 
exploited for sympathy, but operated in the service of Plath's art, through which she discovers "her own speaking voice" and "her own identity". 16

In this 1965 review, Alvarez also spoke of the "myth" that had been gathering around Plath's work, which he linked to the "extraordinary outburst of creative energy in the months before her death, culminating in the last few weeks when, as she herself wrote, she was at work every morning between four and seven, producing two, sometimes three, poems a day." 17 Although Alvarez argued against a confessional reading of Plath's poems, by focussing on the circumstances surrounding the composition of the poems, he placed Ariel within a historical context that is not provided by the poems themselves. Furthermore, in suggesting the poems of Ariel explained the suicide of their author, he conflated the mythopoeic drama in Plath's poems with her life and death:

All this last verse was intensely personal, nearly all was about dying. So when her death finally came it was prepared for and, in some degree, understood. However wanton it seemed, it was also, in a way, inevitable, even justified, like some final unwritten poem. ${ }^{18}$

Alvarez's review helped establish the understanding of Plath throughout the 1960s as a poet whose life and fate were contained within her art. Plath's suicide was ultimately linked to, and seen as a result of, the daring psychological horrors she braved in her poems. The unsigned 1965 review of Ariel in the Times Literary Supplement is typical in describing the "slangy bravado" that creates "mocking caricatures" of "the horrors" the author faces "at the very moment they appear to threaten to suffocate her". The reviewer, clearly aware of Plath's suicide, focuses on the idyllic images of the "stillness" and "purity" of death as a "riposte" against the horror of "being a creature that

\footnotetext{
${ }^{16}$ Alvarez, Al. 'Poetry in Extremis'. Observer. 19 March 1965. 26. In: Wagner-Martin, Linda W. ed. Sylvia Plath: The Critical Heritage. London: Routledge, 1988. 56. Hereafter referred to as 'The Critical Heritage'. 17 'The Critical Heritage'.55.

18 'The Critical Heritage'.55.
} 
dies". ${ }^{19}$ From the moment of Ariel's publication, it became impossible to read the poems outside the historical context of their composition. Plath's suicide seemed to authenticate the suffering described in her poems, which, as Alvarez said, seemed to 'justify' their author's suicide. Plath's readers' fascination with the autobiographical story 'hidden' in her poems was not simply morbid curiosity. It was generally believed (and still is with some justification) that a greater understanding of the biographical circumstances in the poems would give a greater understanding of their meaning. In 'Poets of the Dangerous Way' (1965), for example, M.L. Rosenthal describes the poems as "hard to penetrate in their morbid black secretiveness". And Rosenthal suggests that the poems "make a weirdly incantatory black magic against unspecified persons and situations", which often call for "biographical rather than poetic explanation". ${ }^{20}$ Plath's use of autobiographical events in her dramatic narratives meant that the poet's life and art were perpetually confused.

In 1965, Ariel was named the 'Spring Choice' by the influential Poetry Book Society and Hughes wrote an article for the occasion, which is his earliest published commentary on Plath's poems. This was his first of many prose attempts to describe Plath's life and writings as they finally appear in Birthday Letters:

Behind these poems there is a fierce and uncompromising nature. There is also a child desperately infatuated with the world. And there is a strange muse, bald, white and wild, in her 'hood of bone', floating over a landscape like that of the Primitive Painters a burningly luminous vision of a paradise. A Paradise which is at the same time, eerily frightening, an unalterably spot-lit vision of death ... But the truly miraculous thing about her will remain the fact that in two years, while she was almost fully occupied with children and house-keeping, she underwent a poetic development that has hardly any equal on record, for suddenness and

\footnotetext{
${ }^{19}$ Unsigned Review. 'Along the Edge'. Times Literary Supplement. 25 November 1965, 701. In: WagnerMartin, Linda W. ed. Sylvia Plath: The Critical Heritage. London: Routledge, 1988. 56. Hereafter referred to as 'The Critical Heritage'.

${ }^{20}$ Rosenthal, M.L. 'Poets of the Dangerous Way'. Spectator. 19 March 1965. 367. In: Wagner-Martin, Linda W. ed. Sylvia Plath: The Critical Heritage. London: Routledge, 1988. 60. Hereafter 'The Critical Heritage'.
} 
completeness. The birth of her first child seemed to start the process. All at once she could compose at full speed and with her full weight. The second child brought things a giant step forward. All the various voices of her gift came together ... Ariel is not easy to criticise. It is not like any other poetry. It is like her. Everything she did was just like this, and this is just like her - but permanent. ${ }^{21}$

In this essay, Hughes describes Plath's poems as arriving suddenly, as being inspired by a moon Muse, and he links the poems to Plath's biological creativity. He also links Plath's "uncompromising nature" with the "child desperately infatuated with the world," in order to describe Plath's authentic self, that he believed had gone 'underground' at the time of her father's death, only to re-emerge during the writing of the Ariel poems. Like Alvarez, Hughes speaks of Plath's extraordinary creative development during 1962 and conflates the author with the poems in suggesting that Ariel "is just like her - but permanent". Hughes believed that Plath was able to release her true self by filtering her subjective understanding of her personal history through the mythopoeic archetypal drama within her poems. However, in connecting Plath's true self with the voice of her poems, like Alvarez, Hughes encouraged readers to confuse the subjective psycho-drama he was attempting to describe in Plath's poems with her historical life. Hughes was not blinkered to the autobiographical elements in Plath's poems and once wrote to Anne Stevenson, "[Plath] never did anything that I held against her. The only thing I found hard to understand was her sudden discovery of our bad moments ("Event," Rabbit Catcher") as subjects for poems."22 However, Hughes saw that in Plath's poems these autobiographical elements were subjected to an archetypal dramatic logic. Hughes argued that rather than approaching Plath's poems as incidental pieces responding to objective events, they should be taken as a whole as "chapters in a mythology",23 in which these historical particulars are subsumed by the mythological

\footnotetext{
${ }^{21}$ Hughes, Ted. 'Sylvia Plath: Ariel'. [1965] Winter Pollen: Occasional Prose. London: Faber, 1994. 161-2. Hereafter referred to as 'Winter Pollen'.

${ }^{22}$ Ted Hughes letter to Anne Stevenson. November 1989 quoted in: 'The Silent Woman'. 141-43.

${ }^{23}$ Hughes, Ted. 'Notes on the Chronological Order of Sylvia Plath's Poems.' [1966]. In: Newman, Charles. The Art of Sylvia Plath. USA: Indiana University Press, 1971. 48. Hereafter referred to as 'The Art of Sylvia Plath'.
} 
system. Shortly after writing his 1965 commentary for the Poetry Book Society, Hughes wrote to Sylvia's mother, Aurelia Plath, to explain his intentions in this essay:

I wanted the notes to set an order to the poems - it's an important clue to their unity. And I wanted to set just enough factual notes to the more obscure poems to make a strong close link evident between her poems and her real world. At the same time I wanted to set in the forefront, at as early [a] stage in the great inevitable exegesis as possible, the claim that Sylvia was not a poet of the Robert Lowell/Sexton self-therapy school, but a mystical poet of an altogether higher - in fact of the very highest tradition. I didn't want to press this claim too hard, though I think I have a right to say what I think about it, and I think my claim, even if it raises some temporary would be debunkers, will eventually stand. There is simply nobody like her. I have just finished re-reading all of Emily Dickinson for a small selection and my final feeling is that she comes a long way behind Sylvia. As for Lowell etc, if he is a fine doctor, she is a miracle healer. There is no comparison. But I want to avoid seeming to set myself up as the high priest of her mysteries - and so I've limited myself in these notes to the lowest order of editor's facts. ${ }^{24}$

It is also worth noting here that while Hughes believed that setting an order to Plath's poems by emphasising their mythopoeic unity was important, he was also sensitive, even at this early stage, to any perception that he may be attempting to direct the way the poems would be interpreted.

In 1966, Ariel was published in the United States and was, again, a critical and commercial success. In Robert Lowell's foreword to the American edition, as in the commentaries we have already seen, Lowell conflated Plath with the speakers of her poems. Lowell also describes the way the voice of Plath's poems appeared to assume her identity and speak for her beyond her historical death, particularly in poems in which the

\footnotetext{
${ }^{24}$ Emory University Special Collection Archives (hereafter referred to as 'Emory'). Ted Hughes Collection. Box 55. FF2. [Letter from Ted Hughes to Aurelia Plath, 1965].
} 
drama depicts the speaker undergoing death in order to be reborn, such as 'Lady Lazarus'. Lowell points out that in Plath's poems there is an act of self-transformation taking place, in which the author, like the speaker of the poems, becomes 'something else':

In these poems, written in the last months of her life and often rushed out at the rate of two or three a day, Sylvia Plath becomes herself, becomes something imaginary, newly, wildly and subtly created - hardly a person at all, or a woman, certainly not a 'poetess', but one of those super-real, hypnotic, great classical heroines. This character is feminine, rather than female, though almost everything we customarily think of as feminine is turned on its head. The voice is now coolly amused, witty, now sour, now fanciful, girlish, charming, now sinking to the strident rasp of the vampire - a Dido, Phaedra, or Medea, who can laugh at herself as 'cow-heavy and floral in my Victorian nightgown'... Everything in these poems is personal, confessional, felt, but the manner of feeling is controlled hallucination, the autobiography of a fever. She burns to be on the move, a walk, a ride, a journey, the flight of the queen bee... nothing is too much for the macabre gaiety of her control. Yet it is too much; her art's immortality is life's disintegration. $^{25}$

Lowell describes Ariel as "the autobiography of a fever". It is the record of Plath's harrowing but triumphant transformation through her art. In these poems, Plath's historical identity, phoenix-like, becomes something else, immortal and outside history, becomes something new and "super-real". In attempting to describe what Plath becomes, Lowell reaches for the names of the mythic personae that haunt her poems: "Dido, Phaedra, Medea".

However, because the self-transformation Plath achieves in her poems often relied on revising the nature of her relationships with others in dramatic form, this meant that those closest to her were transformed into characters performing roles in the same mythic

${ }^{25}$ Lowell, Robert. 'Foreword'. Ariel. New York: Harper \& Row. 1966. 
drama. Hughes and Plath had separated because of Hughes's affair at the time she composed Ariel and so he was given particularly scathing depictions in Ariel. The particular historical life of Hughes was thus translated, through the terms of Plath's dramatic dialectic of victim and aggressor so that his historical identity became confused with the role he performed in her myth. The biographical studies that attempted to explain Plath's poems in terms of her life often adopted the dialectic of victim and aggressor in her dramatic poems. Consequently, Hughes found himself depicted as the villain in both the drama of Plath's poems and in the discourses that attempted to make sense of her life.

In managing Plath's literary estate, Hughes found himself in the difficult position of promoting and profiting from these writings in which he was attacked. He also faced the difficult task of being an impartial editor and promoter of Plath's work while trying to maintain his personal privacy and protect his and Plath's children. Over the years that followed Ariel's publication, Hughes was subjected to continual harassment over the way he managed and edited her writings. He responded to his critics by refusing permission to quote from Plath's poems. His actions were seen as a confirmation of his role as the controlling tyrant in Plath's poems, now extending his control over her posthumous life. Eventually Hughes attempted to distance himself from the control of Plath's literary estate, by asking his sister, Olwyn Hughes, to take on the role. In this capacity, and in her connection to Hughes, Olwyn was also criticised on the same terms.

By 1966, following the success of Ariel, it was widely known that Plath was the author of The Bell Jar, and so the novel was re-released in Plath's name in England. The re-release of this semi-autobiographical novel increased the biographical interest and further confused the distinction between life and fiction among Plath's growing following in the late 1960s. The Bell Jar's protagonist Esther Greenwood undergoes a mental breakdown. In the 1970s, The Bell Jar would help direct readings of Plath's suicide attempt of 1953 as a reaction against patriarchal society, and Plath became an iconic martyr for the second wave of feminism. At this stage, The Bell Jar had not yet appeared in the United States. Hughes did not intend to publish the novel in America, as he 
wanted to protect the people negatively portrayed in the book, which was based on Plath's experiences prior to coming to England and meeting Hughes. Aurelia Plath, in particular, was anxious about the repercussions of publishing the novel in America because of the unflattering portrayal she received as the protagonist's mother. In a 1968 letter, Hughes reassured Aurelia that this would not happen:

As for publishing [The Bell Jar] over there simply as a book - again, I think not. I imagine you seeing it on the bookshelf of everybody you know, as it would be, and it seems to me I should ask you not to think about whatever the book might earn for the children - the money is as likely to do them harm as do them good. It's true that copies of the English edition are sold over there, but they're not easy to get - it's not really on the market, and nobody you know is likely to see a copy. You aren't going to see it displayed in bookshops, with foolish advertising phrases. $^{26}$

Despite his assurance, Hughes reneged on this promise to Aurelia Plath three years later. In 1971, he learned that US copyright laws dictated that works by a US citizen who was only published abroad, and who subsequently died, went out of copyright after seven years. Hughes was forced to explain to a dismayed Aurelia Plath that if he did not publish The Bell Jar in the U.S., he would lose ownership of the copyright, leaving anyone else free to then publish the book without Plath's children receiving any money from the proceeds. ${ }^{27}$ In 1971, The Bell Jar duly appeared in America and was hugely successful, introducing Plath to a larger audience than her poems ever would.

1971 also saw the appearance of a memoir of Plath by Al Alvarez in The Observer. When the first of the planned two-part memoir appeared, Hughes quickly dispatched an angry letter to Alvarez, complaining of the intrusion into his family's privacy and pointing out that Plath's children did not yet know that their mother had committed suicide. In his letter, Hughes demonstrates an uncanny insight into the way

\footnotetext{
26 'Emory'. Ted Hughes Collection. Box 55 FF2. [Letter from Ted Hughes to Aurelia Plath 1 July 1968].

${ }^{27}$ Wagner, Erica. Ariel's Gift: Ted Hughes, Sylvia Plath and the Story of the Birthday Letters. London: Faber, 2000. 176. Hereafter referred to as 'Ariel's Gift'.
} 
1 Introduction

the personal details in Alvarez's account would be used in subsequent narratives about Plath:

Before this, the fantasies were hot air, blowing each other away as fast as they were invented, all of them perfectly weightless... All that nonsense is just rumour eating rumour. But now you have provided what seems to be substance, real fact and foundation - the story from one who was in the room. Between her writings and your article is a whole new world of hypothesis. And the commercial and career need for articles and theses and class material will make sure that the world gets overpopulated, and your facts get turned into literary historic monuments. Nobody knows better than you that your article will be read with more interest than the poems ever were, and will be used more by the wretched millions who have to find something to say in their papers. The only difference in the fantasies now will be that they will be ten times as confident in their outrageousness. ${ }^{28}$

Alvarez withheld the second part of his memoir from the Observer after Hughes's letter. Nevertheless, the full article was published later that year as the first chapter of his Alvarez's book, The Savage God: A Study of Suicide (1971). This memoir, like the biographies that followed, although substantially about Plath, contained a vivid description of Hughes:

There was always a sense of his being in touch with some primitive area, some dark side of the self which had nothing to do with the young literary man. This, after all, was what his poems were about: an immediate, physical apprehension of the violence both of animal life and of the self - of the animality of the self. It was also a part of his physical presence, a quality of threat beneath his shrewd, laconic manner. It was almost as though, despite all the reading and polish and craftsmanship, he had never been properly civilised - or had, at least, never

\footnotetext{
${ }^{28}$ Letter from Ted Hughes to Al Alvarez reprinted in: 'The Silent Woman'. 128.
} 
properly believed in his civilisation. It was simply a shell he sardonically put up with for the sake of convenience. ${ }^{29}$

It is interesting to note how Alvarez's portrayal of Hughes and Plath is linked to the impressions he draws from their writings. Hughes, like the predators in his poems, is powerful and dangerous. He is also the "man in black" ${ }^{30}$ (SPC.224) that Plath describes in 'Daddy'. In his description of Plath, Alvarez depicts her, prior to writing the Ariel poems, as sitting anonymously in the background behind Hughes, as though awaiting the liberation she describes in her later poems:

He was a tall, strong-looking man in a black corduroy jacket, black trousers, black shoes; his dark hair hung untidily forward; he had a long, witty mouth. He was in command. In those days Sylvia seemed effaced, the poet taking a back seat to the young mother and housewife. ${ }^{31}$

Alvarez's description of Plath takes its cue from the drama in her poems in suggesting her new poetry allowed her to establish her independence and escape from her husband's powerful presence. Like Lowell, Alvarez suggests Plath achieved some kind of metamorphosis through her poetry as "the poet and the poems became one." 32 Retrospectively, he describes the first evidence of this transformation as being an apparent shift of power between herself and her husband:

Sylvia had changed. No longer quiet and withheld, a housewifely appendage to a powerful husband, she seemed made solid and complete, her own woman again. Perhaps the birth of a son had something to do with this new, confident air. But there was a sharpness and clarity about her that seemed to go beyond that... The balance of power had shifted for the time being to Sylvia. I understood why as I

\footnotetext{
${ }^{29}$ Alvarez, Al. The Savage God: A Study of Suicide. New York: Random House, 1971. 28-9. Hereafter referred to as 'The Savage God'.

${ }^{30}$ Plath, Sylvia. Collected Poems. London: Faber and Faber. 1981. 224. Hereafter referred to in parentheses within the text": e.g. (SPC.224)

31 'The Savage God'. 6.

32 'The Savage God'. 22.
} 
1 Introduction

was leaving. "I'm writing again," she said. "Really writing. I'd like you to see some of the new poems." Her manner was warm and open, as though she had decided I could be trusted. ${ }^{33}$

Alvarez's memoir is a biographical accompaniment to his review of Ariel in suggesting that Plath was a risk taker, both in her everyday life and in her writings. According to this memoir, Plath conjures her deepest fears and faces them over and over again in order to demonstrate her omnipotence, her invulnerability and her ability to defeat and overcome them. Alvarez connects the death in her poems to her earlier suicide attempt and her near death experience on a runaway horse:

She seemed to view death as a physical challenge she had, once again, overcome. It was an experience of much the same quality as riding [her horse] Ariel or mastering a bolting horse - which she had done as a Cambridge undergraduate or careering down a dangerous snow slope without properly knowing how to ski an incident also from life, which is one of the best things in The Bell Jar. ${ }^{34}$

Although Hughes objected to Alvarez's memoir, this account of Plath, and of the situation that led to her suicide, is very close to Hughes's account in Birthday Letters and one must assume that Alvarez's and Hughes's interpretations of Plath's writings were, at least initially, somewhat collusive. Like Hughes, Alvarez believed that Plath experienced her separation from Hughes as a recurrence of her separation from her father who died when she was eight-years-old and that "when she and her husband separated, however mutual the arrangement, she again went through the same piercing grief and bereavement she had felt as a child when her father, by his death, seemed to abandon her." 35 Plath's imaginative connection of these two events explains the reappearance of her father in her poems, and her conflation of Hughes and her father, Otto Plath, in poems such as 'Daddy'. According to Alvarez, Plath was finally unable to manage the psychological material she conjured into her poems. Her suicide was both a cry for help and an attempt

\footnotetext{
33 'The Savage God'. 13.

34 'The Savage God'. 19.

35 'The Savage God'. 38.
} 
to end the despair she had evoked through the creation of the poems she believed would save her.

Alvarez's memoir closes with a description of his final meeting with Plath, when he visited her apartment on Christmas Eve 1962. He portrays her in almost feral terms, connecting her physical presence with the primitive ritual of rebirth celebrated in her dramatic poems:

She seemed different. Her hair, which she usually wore in a tight, schoolmistressy bun, was loose. It hung straight to her waist like a tent, giving her pale face and gaunt figure a curiously desolate, rapt air, like a priestess emptied out by the rites of her cult. When she walked in front of me down the hall passage and up the stairs to her apartment - she had the top two floors of her house - her hair gave off a strong smell, sharp as an animal's. ${ }^{36}$

Alvarez also describes Plath's apartment in such a way as to reflect the loneliness he retrospectively learned she was experiencing following her separation from her husband:

It was rather beautiful, in its chaste, stripped-down way, but cold, very cold, and the oddments of flimsy Christmas decoration made it seem doubly forlorn, each seeming to repeat that she and the children would be alone for Christmas. For the unhappy, Christmas is always a bad time: the terrible false jollity that comes at you from every side, braying about good will and peace and family fun, makes loneliness and depression particularly hard to bear. I had never seen her so strained. $^{37}$

Although, in the same essay, Alvarez claimed that "the myth of Sylvia as a passive victim is a total perversion of the woman she was", 38 his portrayal of the 'powerful' Hughes and

\footnotetext{
36 'The Savage God'. 30.

37 'The Savage God'. 31.

38 'The Savage God'. 40.
} 
the lonely, abandoned Plath, left alone in her apartment that Christmas, were taken up in the subsequent biographical narratives. As Janet Malcolm states in The Silent Woman:

Alvarez's memoir set the tone for the writing about Plath and Hughes that was to follow; it erected the structure on which the narrative of Plath as an abandoned and mistreated woman and Hughes as a heartless betrayer was to be strung... the ordeal of Ted Hughes could be said to date from the publication of Alvarez's memoir in The Savage God and its serialisation in the Observer... Once the plot of the suicidal poetess and her abandonment by the man with the witty mouth was released into the world, there would be no end to the variations played on it or to Hughes's burial alive in each of its retellings. ${ }^{39}$

Hughes's objection to Alvarez's memoir was based on one general complaint that is particularly relevant in terms of our understanding of Birthday Letters. Hughes complained about the way that Alvarez's memoir depicts subjective interpretation as fact:

You didn't distinguish between two completely different kinds of writing... between a subjective work that was trying to reach an artistic form using a real event as its basis, and a documentary work that professes to present anything except errors - everything very purely told and impersonal - of some event that did really happen and is still an active part of some lives. ${ }^{40}$

Hughes's complaint about Alvarez's memoir suggests how might have intended Birthday Letters to be understood: as "a subjective work trying to reach an artistic form" rather than as an objective historical account. At this very early date, he had recognised that the 'story' of his marriage could only ever be understood in these terms. In advertising this subjectivity in Birthday Letters, Hughes can contradict Plath's accounts of the same events while neither of them dispossesses the other of the facts of their lives.

\footnotetext{
39 'The Silent Woman'. 23.

40 ‘The Silent Woman'. 129.
} 
In the same year that Alvarez's memoir appeared, Hughes published two further collections of Plath's poetry. The first of these, Winter Trees, included Plath's long poem for voices 'Three Women', and collected eighteen poems “out of the batch from which the Ariel poems were more or less arbitrarily chosen" that were "all composed in the last nine months of Sylvia Plath's life". 41 These included eight of the fourteen poems Hughes had removed from Plath's selection for Ariel ('The Rabbit Catcher', 'The Swarm', 'Lesbos', 'The Other', 'Stopped Dead', 'The Courage of Shutting-Up', 'Purdah', and 'Thalidomide'). The second book, Crossing the Water, was comprised of a group of Plath's earlier uncollected poems written during 1960-1961 between The Colossus and Ariel. Crossing the Water included two further poems that Hughes had removed from Plath's selection for Ariel ('Magi' and 'Amnesiac'), which left only four poems unpublished from Plath's original selection for Ariel. These poems ('The Detective', 'A Secret', 'The Jailer' and 'Barren Woman') finally appeared in 1981, in Plath's Collected Poems.

Following publication of Winter Trees and Crossing the Water, Alvarez questioned the way Plath's corpus was being handled in an Observer article, in which he criticised Hughes for attempting to create additional revenue by publishing Plath's poems in small editions. Hughes responded to Alvarez in an open letter to the newspaper, explaining that the two selections had been published separately because they represented two distinct periods, and had two distinctly different types of inspiration (as did The Colossus and Ariel). Hughes also explained publicly for the first time that the version of Ariel he had published in 1965 had been a compromise between Plath's manuscript selection, the need to protect the people thinly-disguised in the more aggressive poems, and his wish to publish a range of poems that best demonstrated the range of Plath's talent. Hughes's comments about his re-ordering of the Ariel manuscript went unnoticed at this time. It was not until ten years later when he repeated his disclosure in the notes to Plath's Collected Poems that he was accused of interfering with Plath's intentions. Nevertheless, it is around this time that we can begin to detect the way that Hughes was becoming trapped in the mythic role Plath had assigned him in her mythopoeic reading of

${ }^{41}$ Hughes, Ted. 'Note' In: Plath, Sylvia. Winter Trees. London: Faber, 1971.7. 
her life. The controlling tyrant within Plath's poems was now in control of the poems themselves. Janet Malcolm has pointed out that once a particular narrative becomes established it is very difficult to dislodge:

The narratives of journalism (significantly called "stories"), like those of mythology and folklore, derive their power from their firm, undeviating sympathies and antipathies. Cinderella must remain good and the stepsisters bad. "Second stepsister not so bad after all" is not a good story. ${ }^{42}$

The articles and biographical studies that took their cue from Plath's late poems fixed Hughes firmly in his role as the villain in the Plath story. This resulted in extreme vehemence being directed at Hughes by Plath's most fervent supporters. The feminist poet Robin Morgan's poem 'Arraignment' (printed in her 1972 book of poems, Monster), for example, suggested that he was responsible for Plath's suicide and called for his castration and lynching. When Hughes threatened to sue the publisher, Random House agreed to withdraw all copies of the book from any markets in the Commonwealth. Nevertheless, pirated copies were still published (often with Morgan's consent) in Canada, Australia, New Zealand and England. Throughout the 1970s feminists picketed Hughes's poetry readings, and reading tours were cancelled in Canada, Australia, New Zealand, and the United States because of threats of protest and disorder.

In 1976, five years after Alvarez's memoir, Edward Butscher published the first biographical attempt to map Plath's life from her birth: Sylvia Plath: Method and Madness. Like Alvarez, Butscher established clear links between Plath's writing, life and suicide. Method and Madness exemplified the power of paraphrase that would characterise the studies of Plath that followed. Because Butscher did not analyse large sections of Plath's poetry in any great detail, he did not require permission from the Plath Estate. Furthermore, Butscher did not quote his sources directly and when the book

\footnotetext{
42 'The Silent Woman'. 69.
} 
appeared several of his sources complained that they had been misrepresented in the book. $^{43}$

1976 also saw the publication of Letters Home, a selection of Plath's letters to her mother. Aurelia Plath had requested Hughes's permission to publish a selection of letters that she hoped would act as a corrective to Plath's portrayal of her as Esther's shallow and emotionally-cold mother in The Bell Jar. Aurelia explained her reasons for wanting to publish the correspondence in a 1973 letter to Hughes:

I feel an intense obligation to do this to dispel many of the incorrect statements that have been in the press about her relationship to members of her family (where she was loved, wanted, and well served and knew it all her life long!) So few people are endowed with a lively imagination (it would seem) that they cannot conceive of a creative artist's blending of truth and imagination; and, in Sylvia's case where her memory had been tampered with, the picture and the understanding is made all the more difficult. ${ }^{44}$

Letters Home offers an invaluable record of Plath's intimate relationship with her mother. For the purposes of this study, Letters Home is useful in demonstrating the protean complexity of Plath's projected self-image, particularly when her letters are considered alongside poems and private journal entries she wrote on the same day. The disparities and contradictions between these writings illustrate the difficulty of determining exactly

\footnotetext{
${ }^{43}$ See: Hughes, Olwyn. 'Reviewing Sylvia Plath' [In response to 'Sylvia Plath's Apotheosis' (24 June 1976)] The New York Review of Books. 30 September 1976. Vol. 23. 15. Olwyn's letter to the editor of The New York Review of Books along with other letters held at Emory University indicate that Hughes was deeply upset by the appearance Butscher's book. Hughes mistakenly refers to Beutscher rather than (Dr) Beuscher [Plath's psychoanalyst] in the Birthday Letters poem 'Night Ride on Ariel', conflating Beuscher with the biographer Butscher. Hughes had been equally upset by Dr Beuscher's advice in her letters to Plath during their separation, which he found after Plath's death. Dr Beuscher had written to Plath: "I would advise going the whole hog and getting a divorce...Y You can certainly get the goods on him now while he is in such a reckless mood... If this seems to final to you, just remember, you can always marry him again if you want to... Keep him out of your bed... Have NOTHING to do with his family... All of the above I tell you not only out of common sense, but out of very bitter experience in my own first marriage." Grolier Club Exhibition. New York. 'No Other Appetite: Ted Hughes, Sylvia Plath and the Blood Jet of Poetry'. 14 September - 19 November 2005. Exhibit 123. Letter from Ruth Beuscher to Sylvia Plath, 26 September 1962.

${ }^{44}$ 'Emory'. Ted Hughes Collection. Box 5 FF 18 (MSS 644). [Letter from Aurelia Plath to Ted Hughes of 11 March 1973]
} 
who Sylvia Plath was, what she thought, how she felt, and what exactly happened in her life, even when we have her first-hand accounts. In 1976, although the readers of Letters Home did not yet have Plath's journals, they had her poems and novel. On the strength of these, many readers interpreted her breezy optimism and repeated expressions of gratitude for support and assistance in her letters to her mother as her way of coping with the demands of a suffocating mother who lived vicariously through her daughter's achievements. The dramatic image of Esther Greenwood's mother in The Bell Jar proved a more difficult a role for Aurelia Plath to dismantle than she had imagined and, like Hughes, Aurelia was consigned to the dramatic role Plath allotted her in her poems.

1976 also saw the first book-length critical study of Plath's poetry. Judith Kroll's Chapters in a Mythology interprets Plath's poems as a mythopoeic drama rather than confessional pieces. Like Hughes, Kroll argues that we should approach Plath's poetry as art, and not "as one might see the bloodstains at the site of a murder": ${ }^{45}$

It is important to separate the aesthetic success of her poems from the biography, on which it does not depend. One can certainly read the poems just for biography or 'confession', simply to 'get the story' and 'find out what happened to her'; but if one does this - as is fairly common among her readers - one has in a sense predetermined the scope of one's reading, prejudiced what one is reading for ('the life of a suicidal, male exploited genius' - the source and nature of whose genius is, however, oddly taken for granted; or not enquired into; or by some peculiar logic ascribed to her suffering). One therefore misses other meanings, not relevant to a focus on sensationalistic confessional aspects, by a priori screening them out. ${ }^{46}$

Kroll's main thesis is that Plath uses events and characters from her life to furnish a personal mythology and transcend the limits of her situation and identity. The characters in Plath's poems are not realistic or particular; they do not exist as untidy individuals, but

\footnotetext{
${ }^{45}$ Kroll, Judith. Chapters in a Mythology: The Poetry of Sylvia Plath. London: Harper \& Row, 1976. 1. Hereafter referred to as 'Chapters in a Mythology'.

46 'Chapters in a Mythology'. 49.
} 
perform archetypal roles. Furthermore, Kroll points out that Plath has a tendency to amend her personal history to fit the myths she constructs. In 'Daddy', for example, the speaker says "I was ten when they buried you" when Plath had, in fact, been eight years old when her father died. Autobiographical accuracy is therefore subordinate to dramatic effect. Ten years fits better into the cyclical pattern of death and rebirth described in Plath's poem 'Lady Lazarus', for example, in which the speaker dies “One year in every ten" (SPC.244). Chapters in a Mythology is particularly useful for the present study because it offers a close reading of Plath's mythology (her imagery, symbols and drama), that reflects Hughes's reading of Plath's poems. We will look at this reading in detail in Chapter 5 ('The Plath Myth'). However, when Chapters in a Mythology appeared, Hughes's support of Kroll's thesis (he allowed his letters to Kroll to be reproduced in her book) resulted in the book being tainted it by its 'authorised' status. Some of the book's detractors claimed it was a 'sanitised' interpretation of Plath's poems that directed attention from the biographical circumstances in which the poems were written. In a 1977 letter to the New York Review of Books, Kroll responded to these criticisms by arguing that she had reached her own conclusions about Plath while studying at Smith College, and only wrote to Hughes in the later stages of her thesis to request permission to view Plath's manuscripts. Kroll claimed that Hughes's only editorial suggestion was that she should remove the analysis of a particular poem; a suggestion that she had considered and rejected. ${ }^{47}$

Hughes published Plath's Collected Poems, which won a Pulitzer Prize. The book included the remainder of Plath's known unpublished poems and a selection of her juvenilia. Hughes arranged the poems chronologically, dating the poems where dates of composition where known, and provided a comprehensive set of notes about the circumstances of the poems' composition and appearance. In one of these notes, Hughes explained, for the second time, that prior to publishing Ariel in 1965, he had re-arranged the selection of poems:

\footnotetext{
${ }^{47}$ Kroll, Judith 'Not a Conspiracy'. The New York Review of Books. Volume 24, No.8. 12 May 1977.
} 
1 Introduction

The Ariel eventually published in 1965 was a somewhat different volume from the one she had planned. It incorporated most of the dozen or so poems she had gone on to write in 1963, though she herself, recognising the different inspiration of these new pieces, regarded them as the beginnings of a third book. It omitted some of the more personally aggressive poems from 1962, and might have omitted one or two more if she had not already published them herself in magazines - so that by 1965 they were widely known. The collection that appeared was my eventual compromise between publishing a large bulk of her work - including most of the post-Colossus but pre-Ariel verse - and introducing her late work more cautiously, printing perhaps only twenty poems to begin with. $^{48}$

What Hughes was saying here was not new; he had already described rearranging Plath's selection for Ariel in his 1971 letter to The Observer, in defence of his publication of the two volumes Crossing the Water and Winter Trees. Furthermore, Collected Poems contained the remaining unpublished poems from Plath's Ariel selection. Nevertheless, his disclosure suddenly became controversial. Perhaps, in providing a list of Plath's original Ariel sequence (in the notes to Plath's Collected Poems), and in printing the final four unpublished poems from Plath's selection ('The Detective', 'A Secret', 'The Jailer' and 'Barren Woman'), the nature of Hughes's interference with Plath's intentions became more evident. However, it seems more likely that the controversy related to the fact that, by 1981, Hughes was firmly established as the 'villain' in the Plath myth that served her feminist readers.

In Marjorie Perloff's article, The Two Ariels: The (Re) Making of the Sylvia Plath Canon (1986), she argued that the narrative in Plath's original Ariel sequence had told the story of the breakdown of her marriage following her betrayal by her husband, the reestablishment of her independence and the transcendence of her suffering. According to Perloff, Hughes's interference with Plath's Ariel poems was designed to remove himself as the cause of Plath's suffering and link her suicide to the re-experience of the trauma of

${ }^{48}$ Hughes, Ted. (ed.) 'Introduction'. (SPC.15). 
her father's death. Perloff argued that Hughes removed the poems in Ariel that were critical of him and replaced these with a number of Plath's late "death poems" in order to remove Plath's criticism of himself, emphasise her obsession with her dead father, and suggest to readers that she had a death wish, making her death appear inevitable. The story that Perloff describes Hughes promoting in his re-arrangement of Ariel is similar to the story he tells in Birthday Letters and, in this sense, we can see Birthday Letters as a continuation of his management of Plath's literary estate. Throughout Birthday Letters, Plath's preoccupation with her father is represented dramatically by Otto Plath's haunting of her. However, Perloff's suggestion that Hughes was attempting to distract Plath's readers away from the mythic theme of transcendence and rebirth in Plath's poems is harder to sustain within the Birthday Letters narrative which, as the title Birthday Letters suggests, features Plath's rebirth symbol prominently (as do Hughes's other critical writings about Plath).

The suggestions that Hughes was censoring, suppressing and directing how Plath's writings were being read led him to take the bold step of deciding to publish a selection from her private journals. Hughes believed that if readers could have this unmediated access to how Plath explained her life and writing privately to herself this would dispel some of the 'myths' about their marriage and show readers what he had always argued: that Plath, as a mythopoeic poet, made sense of her life in mythic terms. In 1982, Hughes published The Journals of Sylvia Plath, which consisted of a selection from Plath's journal notes from 1950 and 1962. As Diane Middlebrook explains, these journals show the way that Plath experimented with her writing in her journals, creating and recreating her self-image, and attempting to make her experiences more universally relevant:

Ostensibly, the journal-keeper is making notes about daily life. But the journal of the writer is often more like the barre of the ballerina: she works out in front of a mirror, watching an ideal version of herself attempting difficult moves, trying to get them right. Trying to sketch a character. Compose a scene. Describe her surroundings: food, clothing, noise, furnishings, weather. Or, turning inward, 
anatomize a grandiose fantasy. Grope around in the muddle of her conflicts. Encourage herself. ${ }^{49}$

In the 'Foreword' to The Journals, Hughes made an even more controversial disclosure concerning his management of Plath's literary estate. He confessed that, shortly after Plath's suicide, he had destroyed her final journal, and had misplaced one of the journals that covered the period of 1962, thereby removing the journal record during her composition of the Ariel poems and in the final months of her life prior to her suicide:

These journals exist as an assortment of notebooks and bunches of loose sheets. This selection contains about a third of the whole bulk, which is now in the Neilson Library at Smith College. Two more notebooks survived for a while, maroon-backed ledgers like the '57-'59 volume, and continued the record from late ' 59 to within three days of her death. The last of these contained entries for several months, and I destroyed it because I did not want her children to have to read it (in those days I regarded forgetfulness as an essential part of survival). The other disappeared. ${ }^{50}$

Hughes's confession about his destruction and loss of Plath's late journals, as one would expect, was taken as further evidence of his interference and censorship of her. The ledgers Hughes described as having misplaced have not re-surfaced to date, and we can only hope that one day they will. The Journals did not encourage a radical re-evaluation of Plath (or of Hughes) and were used, as one might expect, to bolster pre-existing notions. Hughes, and co-editor Frances McCullough, had removed sections of Plath's private criticisms concerning people around her, along with other less interesting sections, in order to protect people and make the volume stronger. The withheld sections of The Journals were marked in the published version by ellipses. These ellipses were seen by Hughes's critics as further evidence of his censorship of Plath's writings and his

\footnotetext{
49 'Her Husband'. 15

${ }^{50}$ Hughes, Ted. (ed.) 'Foreword'. The Journals of Sylvia Plath. New York: The Dial Press, 1982. xiii.
} 
manipulation of the way she was understood. Consequently, many critics concentrated on what The Journals left out rather than what they revealed about Plath.

Over the years, Hughes's critics complained that he suppressed Plath's criticism of him in order to protect his own image. However, he believed that, on the contrary, in suppressing Plath's "more difficult side", he had encouraged the notion that Plath was a 'martyr' and that he was the 'devil' of her poems. As he explained in a 1988 letter to Lucas Myers, he felt he had been accused, found guilty, and condemned by the reading public, particularly in America:

I think, by suppressing, or trying to suppress for the children's sake all accounts etc of Sylvia's more difficult side, I have done everybody an ill-service. Myself especially, perhaps. Colluding at every stage with Aurelia's attempt to exonerate herself and sustain her dream of the perfect daughter, I have known all along that I was in fact incriminating myself - but I'm needing all my philosophy now to tolerate the sentence which has, I see, been passed on me and which several generations of U.S. students now accept as history, insofar as they're aware of Sylvia and myself. It was certainly the end of, gradually arrived at, but now pretty well irreversible I imagine - the fortunes of my verses and reputation in the U.S. Though I'm not sure any other course of action would have made any difference there. ${ }^{51}$

Although Hughes believed he had colluded with Aurelia Plath's "to exonerate herself and sustain her dream of the perfect daughter", this collusion with Plath's mother was certainly over by the time he published The Journals. Aurelia Plath is one of the most frequent victims of Plath's criticisms in The Journals, and these private comments about her mother dispelled the image of a close-knit mother-daughter bond Aurelia had encouraged in Letters Home. Aurelia's letters to Hughes following the publication of The Journals indicate the extraordinary pain and feelings of betrayal their publication caused.

51 'Emory'. Ted Hughes Collection. Box 1 FF20 MSS 865 [Letter from Ted Hughes to Lucas Myers 1988]. 
In one letter, she expresses a belief that, in order to make such inaccurate comments, Plath's electro-convulsive treatment must have affected her memory:

Perhaps you can sense the tragedy that The Journals have spelled for me. Sylvia must have been deeply and emotionally disturbed ever to doubt my love for her. After all, my whole life was dedicated to my two children whom I loved above all else. "It rings so absolutely true" states one review of The Journals, repeated by others. The phrase obscures a host of errors, for as is often the case after her electric shock treatment, memory is permanently distorted in places. And Sylvia's memories are horribly distorted. ${ }^{52}$

Aurelia also complained about how reviewers treated Plath's journal entries as an objective record of actual events, despite the fact that Plath had often used her journals to map out conflicts, and had often written while angry or suffering from depression:

It is cruel that for all I thought, all the love, all the work, I am pictured as an antagonistic figure. It is tragic enough to lose my only daughter, but that her private papers written as she states "when I am at my wit's end, I write in my Journal" (the reviewers never note that); nor is note taken of the deep depression she was suffering at the time and had been hospitalised for... Since I had not read any books about Sylvia, the entire contents of The Journals were a complete shock to me. She kept one part of her "double" experience completely private, and neither Warren nor I had an intimation regarding it. Naturally, I suffer for her pain, understand her rebellion at the circumscribed period of time, sense her confusion and agonise over the unwarranted misinterpretation of her mental illness as fact and reality in our family experience. ${ }^{53}$

\footnotetext{
52 'Emory'. Ted Hughes Collection. Box 5 FF 18 (MSS 644). [Letter from Aurelia Plath to Carol Hughes 5 July 1982]

53 'Emory'. Ted Hughes Collection. Box 5 FF 18 (MSS 644). [Letter from Aurelia Plath to Carol Hughes 5 July 1982]
} 
In a 1982 letter to Ted's second wife, Carol Hughes, Aurelia points out that Plath's portrayals of relationships and of those around her were often written in an unmeasured state because Plath used her journals as a cathartic way of purging negative emotions. Aurelia also pointed out that her daughter's suicide meant that Plath had no opportunity to revise her often rash criticisms and comments:

Sylvia, who would be 50 years old next October 27 would certainly be mature enough not to want the whole world to learn of her indiscretions, her chosen poses of martyrdom, which when written down during periods of depression and frustration, her self-doubt as to her ability to "live on her writing" which frightened her - it was an outlet for these negative emotions - once down they were out and she felt freed to take up the daily tasks, to see life again more "whole". By choosing, on these pages, justly and unjustly - more often the latter her "whipping boy" as victim, she purged herself as another might do by chopping wood furiously in a time of anger to rid himself of the emotion. There is no exercise toward attaining perfection but a very private method of ridding oneself of one's demons. I do believe that Sylvia's "agitation" at the time of the publication of The Bell Jar in England was largely due to her dawning realization of the grave injustices she had committed in caricaturing many of whom had served and loved her best. At 50, she would, I am sure, not have wished to repeat that grave mistake. In fact, when she spoke to me - and read part - of the sequel she was working on and told me it was "seeing life through the eyes of health", (which she burned in my presence) I now understand she had second thoughts about her first novel. ${ }^{54}$

Like Hughes, Aurelia felt she was trapped in a role sketched in Plath's writings that had become confused with fact. Aurelia too would have to perpetually play this role in the many biographies that organised their descriptions of Plath's relationships through the sympathies and antipathies described in Plath's writings. And there were still many more

\footnotetext{
54 'Emory'. Ted Hughes Collection. Box 5 FF 18 (MSS 644) [Letter from Aurelia Plath to Carol Hughes 2 September 1982]
} 
biographies to come. Retrospectively, Hughes believed that he left in too much in The Journals. Although he never expressed any remorse relating to Plath's comments about Aurelia, having some sympathies with Plath's privately expressed comments based on his own observations, he regretted leaving in several comments Plath had made privately about others. In a 1994 letter to Seamus Heaney, he explained why he had published The Journals and his subsequent regrets:

I somehow succumbed in my somnambulist preface ${ }^{55}$ - that if readers could meet Sylvia talking to herself, could overhear just how she explained everything to herself, they would see the light, and understand the whole complication. All the biographical fantasies and politicised puppet substitutes would be miraculously dispelled. Everybody would thereafter understand her perfectly etc. All I had to do, I thought, in the general trimming of the whole journal to about a third of its length... was make sure Sylvia's onslaughts on people were cut out, together with the coincidental swatches of my own life that I wanted to keep for myself... I convinced myself that in such a context such things would be recognised as Sylvia's foibles, genuine features of the living person, inseparable from the photographic authenticity of the self-portrait... So it's been quite a shock. Plain as day to me now, as I suppose everyone else from the moment the book appeared: only one person is responsible for every phrase in it. Not Fran McC who was working for a book that would not just die, and certainly not Sylvia pouring her heart out (least of all her) - but me. Me all on my own. I re-aimed all those little darts and planted them in their targets where they remain waggling away, well in past the barbs. I published all her admirations of me. Nobody can feel she's to blame - she had the grace to realise it was private and hid it away in notebooks. So there it is. Absolutely unforgivable. ${ }^{56}$

Hughes's letter to Heaney was written twelve years after the release of The Journals following an apparent retrospective realisation about publishing criticisms Plath had

\footnotetext{
${ }^{55}$ In depicting his younger self in Birthday Letters, Hughes repeatedly describes himself as 'sleepwalking'. 56 'Emory'. Ted Hughes Collection. Box 54. FF2. [Letter from Ted Hughes to Seamus Heaney 24 January 1994]
} 
made about some of their mutual friends. On the same day as his letter to Heaney (24 January 1994), drafts in the Emory archives indicate he sent several letters of apology to friends whom he felt had suffered public criticism from Plath in the published version of her Journals.

In 1987, Linda Wagner-Martin's Sylvia Plath: A Biography provided another portrait of Plath that described her as the victim of her husband Hughes. In her preface Wagner-Martin issues a litany of complaints about Hughes's control of Plath's literary estate: he did not publish all of Plath's juvenilia in Collected Poems; he sealed a group of Plath's papers at Smith College until 2013; he sealed another group of papers until the death of Aurelia and Warren Plath (Sylvia's brother); he destroyed Plath's final journal, misplaced (or destroyed) another journal, and misplaced or destroyed 130 pages of Plath's second novel Double Exposure; he would not agree to an interview. Despite repeated provocation from his critics, Hughes steadfastly refused to speak of his relationship with Plath, and restricted his written comments about Plath to commentary on her writings. However, in April 1989, he broke this silence spectacularly, in a letter to The Independent. Hughes was responding to an article by the biographer Ronald Hayman, who, noting that Plath's headstone was missing, accused Hughes of failing to maintain the upkeep of Plath's grave. Hughes angrily responded that the headstone had been removed temporarily for repair after the name 'Hughes' had been chiselled from the inscription 'Sylvia Plath-Hughes' for the third time (he eventually replaced it with a headstone that had embossed letters which could be more easily replaced). Hughes also pointed out a number of factual errors in Hayman's article, such as Hayman's assertion that Plath had lived in Cornwall rather than Devon. Speaking about the inaccuracies and speculations that appeared in the biographies that continually intruded upon his private history, he complained: "I hope each of us owns the facts of her or his own life." ${ }^{57}$ This inability of Hughes to 'own' the facts of his life appears to have been one of the major torments of his life, and it was an ordeal that he finally addresses in Birthday Letters.

57 'The Silent Woman'. 8. 
In 1989, another biography appeared, but this time with the approval of the Plath estate. Anne Stevenson's biography Bitter Fame: A Life of Sylvia Plath appears to have been an attempt by the Plath estate to correct the partisan image of Plath as a longsuffering, passive victim of her brutal philandering husband. The biography came about when Stevenson contacted Hughes's sister, Olwyn, in relation to a small biography she had been commissioned to write for the 'Writers and their Work' series. Olwyn Hughes offered Stevenson the opportunity to write a fuller biography with the estate's full cooperation, and Stevenson, recognising the value of such a work, agreed. However, as the project proceeded Stevenson became unhappy with Olwyn's intrusive editorial control, which gave Stevenson the feeling that she was being used as a pawn in a public relations exercise. After much wrangling between the two, Stevenson insisted upon Olwyn Hughes's 'co-authorship' being recorded as an 'Author's Note' prior to the book's preface:

In writing this biography, I have received a great deal of help from Olwyn Hughes, literary agent to the Estate of Sylvia Plath. Ms. Hughes's contributions to the text have made it almost a work of dual authorship. I am particularly grateful for the work she did on the last four chapters and on the Ariel poems of the autumn of $1962 .^{58}$

Olwyn's insistence on editing everything in Bitter Fame meant that the book was widely seen as part of the estate's wider conspiracy to protect Hughes's image, on this occasion, by attacking Plath. Certainly, in Bitter Fame, Plath is portrayed as demanding, uncompromising and obstinate. Many of the episodes recorded in the biography depict Plath as ambitious, as being jealous of any attention Hughes gave to other women, and as having a pathological temperament. According to Bitter Fame, Plath's foibles, and her inability to compromise, alienated many of the people around her. To reaffirm the negative portrayal of Plath in the biography's main narrative, Bitter Fame also featured appendices in which several friends provided unsympathetic portraits of Plath.

\footnotetext{
${ }^{58}$ Stevenson, Anne. Bitter Fame: A Life of Sylvia Plath. Boston: Houghton Mifflin Co, 1989. x. Hereafter referred to as 'Bitter Fame'.
} 
Particularly scathing is Dido Merwin's memoir: 'Vessel of Wrath: A Memoir of Sylvia Plath', which Merwin defends as a necessary counterbalance to the inaccuracies offered in other biographical accounts:

There aren't, of course, all that many people in possession of the facts; and among those of us who are, there must be one or two who can't afford to fall foul of feminist apartheid or risk a boycott by the Lib Lobby. Moreover, nobody I know was prepared to say a word as long as Sylvia's children were growing up, with the result that her hagiographers got a head start of two decades plus in which to shape their apotheosis, which snowballed onward and upward virtually unchallenged. ${ }^{59}$

Critics of Bitter Fame suggested that Hughes was behind its negative portrayal of Plath. However, Hughes's private correspondence with Stevenson suggests that he did not believe the book represented his views of Sylvia. In one illuminating letter to Stevenson of 1988 , he explained his decision to remain silent about his marriage:

I have never attempted to give my account of Sylvia because I saw quite clearly from the first day that I am the only person in this business who cannot be believed by all who need to find me guilty. I know too that the alternative remaining silent - makes me a projection post for every worst suspicion. That my silence seems to confirm every accusation and fantasy. I preferred it, on the whole, to allowing myself to be dragged out into the bull-ring and teased and pricked and goaded into vomiting up every detail of my life with Sylvia for the higher entertainment of the hundred thousand Eng Lit Profs and graduates who as you know - feel very little in this case beyond curiosity of a quite low order, the ordinary village kind, popular bloodsport kind, no matter how they robe their attentions in Lit Crit Theology and ethical sanctity. If they do feel anything more

59 'Bitter Fame'. 336. 
vigorous, it is generally something even lower: status anxiety, their professional angst on the promotion scramble. ${ }^{60}$

In 1991, Jacqueline Rose's The Haunting of Sylvia Plath provided a feminist poststructuralist and psychoanalytical reading of Plath's writings. In her introduction, Rose claimed that Hughes was offended by her reading of 'The Rabbit Catcher' as a critique of the innate violence in heterosexual relationships, and had threatened to take legal action to prevent the book being published. Rose defended her readings along poststructuralist lines:

Interpretation of a literary work is endless. There is no one true place where it can be halted. It cannot be arrested at the point where it comes into conflict with how a writer sees their own depiction of others or of themselves. Once a piece of writing is put into circulation, it ceases - except in the most material sense - to be the property of its author. Nor can it be controlled and limited by the views of any one individual, no matter how close to the subject they may have been, or still feel themselves to be. In writing this book I have faced what I believe to be an attempt to exercise such control and to impose limits on what may be said about the writings of Sylvia Plath. This attempt has been made in the name of protection of privacy, of 'factual' accuracy and of the ethics of scholarship. It has been reinforced by the threat, overt and implied, of legal action... On the points over which we have failed to agree, it appears that for Ted and Olwyn Hughes there is only one version of reality, one version - their version - of the truth. ${ }^{61}$

With Rose, as with the earlier writings about Plath, the dispute between Plath's critics and the Plath estate revolved around possession of, and perceived distortions of, 'the truth'. For critics such as Rose, the freedom to interpret Plath's writings is a political and cultural right; for Ted Hughes, it is about the right to 'own the facts of one's life'.

\footnotetext{
${ }^{60}$ Letter from Ted Hughes to Anne Stevenson quoted in: 'Ariel's Gift'. 10.

${ }^{61}$ Rose, Jacqueline. The Haunting of Sylvia Plath. London: Virago Press, 1991. xi-xiv. Hereafter referred to as 'The Haunting of Sylvia Plath'.
} 
More scandalous revelations about Hughes featured in two new biographies that same year. Ronald Hayman's The Death and Life of Sylvia Plath (1991) revealed in print for the first time the 'open-secret' of Assia Wevill's suicide. Wevill's relationship with Hughes, which had led to his separation from Plath in 1962, had continued after Plath's suicide. Assia left her husband David Wevill, and continued a relatioship with Hughes until 1969, when, in a tragic gesture that recalled Plath's suicide; she gassed herself and their daughter, Shura. Paul Alexander claimed in Rough Magic: A Biography of Sylvia Plath (1991) that Plath had undergone a secret abortion in 1956. Alexander never disclosed the source of this scenario, and subsequent biographical enquiries suggest that a number of Alexander's claims are demonstrably false. Nevertheless, spurious claims such as these helped to sustain the dramatic scenario in which Plath was a victim of the tyrannical Hughes.

In 1994, Janet Malcolm's The Silent Woman appeared. This offered a sobering analysis of the biographical studies of Plath by examining the motivations and assumptions of the biographers themselves. Malcolm exposed the inaccuracies and biases in a number of the biographies and illustrated how they, like all 'factual' investigations, are limited by their focus and intent. The Silent Woman provides a useful overview of the Plath biographies that is sensitive to Hughes's "ordeal" throughout his 'silent' years. Malcolm finally determined that it was Hughes's 'bitter fate to be perpetually struggling with Plath over the ownership of his life, trying to wrest it back from her."62 In addition to challenging the notion of Hughes's perceived role in his marriage to Plath, Malcolm disputes the notion that he is a suppresser of Plath's writings. Having read through Plath's complete uncensored journals at Smith College, Malcolm concluded that "The cuts that concern Hughes seem pathetically modest: excisions of encomiums of his "banging virility" or of an occasional wifely complaint about the state of his nails."63 Malcolm's challenge to the Plath story was the first wavering in the feminist myth that surrounded Plath's life and writings. However, among the general throng of voices, Malcolm's opinion was somewhat anomalous. Hughes eventually

${ }^{62}$ 'The Silent Woman'. 140.

63 'The Silent Woman'. 98. 
accepted that the only way to dispel the myths surrounding his elisions in The Journals was to publish an unexpurgated version. He died before the project was completed and new unabridged version of The Journals was finally edited and published by Karen Kukil in 2000 .

In 1994, Hughes's New Selected Poems was published and included unpublished poems that would finally appear as part of the narrative in Birthday Letters: 'Chaucer', 'You Hated Spain', 'The Earthenware Head', 'The Tender Place', 'Black Coat', 'Being Christlike', 'The God', and 'The Dogs Are Eating Your Mother'. Reviews of New Selected Poems suggest that critics did not recognise the poems' biographical relevance, or even link the poems with Sylvia Plath. Certainly, nobody imagined at this point that a larger sequence existed that would eventually be published as Birthday Letters. In a 1998 letter to Seamus Heaney, Hughes explained that he had wanted to publish "30 or 40" of the poems in 1994, but had "stuffed them back in the sack" and had "hidden them like the family idiot" because his wife Carol's sister was dying and he did not want Carol to have to endure the publicity the poems would generate at that time. ${ }^{64}$

That same year, eight essays Hughes had written over the years about Plath's writings were collected in Winter Pollen: Occasional Prose ('Sylvia Plath: Ariel', 'Publishing Sylvia Plath', 'Collecting Sylvia Plath', 'Sylvia Plath and Her Journals', 'Sylvia Plath: The Evolution of Sheep in Fog', and 'Sylvia Plath's Collected Poems and The Bell Jar ${ }^{65}$ ). Otherwise Hughes's comments about Plath are confined to his notes and introductions to her works, or remain in private letters, such as in the collection held at Emory University in Atlanta and in the British Library in London.

In 1998, after requesting permission from his children, Hughes finally decided the time was right to publish Birthday Letters. The book was kept secret until 17 January 1998 (twelve days before the book's publication) when the first of twelve poems were

\footnotetext{
64 'Emory'. Seamus Heaney Collection: Box 40 FF16. Letter from Ted Hughes to Seamus Heaney dated 1 January 1998. [Restricted]

${ }^{65}$ The essay 'Sylvia Plath's Collected Poems and The Bell Jar' was only published in the U.S. edition of Winter Pollen: Scammell, William. (ed.) Hughes, Ted: Winter Pollen. New York: Picador. 1995. Hereafter referred to as 'Winter Pollen: U.S. edition'.
} 
serialised in The Times. According to Erica Wagner, who selected the poems and wrote the accompanying commentary, Hughes had insisted that the date of Birthday Letters' publication - 29 January - be printed alongside the publication details because of its astrological significance: being "the day the planet Neptune, the ruler of poetry, enters Aquarius, a constellation considered by astrologers to have much to do with the collective awareness." $" 66$ The appearance of Birthday Letters sent shockwaves through the literary world. Hughes had remained silent about Plath for over thirty years; his poetry had been impersonal and had fought to keep his personal life private, and yet suddenly, without warning, here was a large collection of deeply personal poems about their relationship. When Hughes died from cancer several months later, his decision to 'publish and be damned' was perhaps better understood as a final attempt to exert an influence on the way his and Plath's lives were 'read'. On hearing of Hughes's death, the critic Germaine Greer said, somewhat repentantly:

Feminists never had any intention of dealing with Ted Hughes. Ted Hughes existed to be punished - we had lost a heroine and we needed to blame someone and there was Ted. ${ }^{67}$

Birthday Letters won the 1998 Forward Prize and the Whitbread Prize for poetry and was widely applauded for its poetic as well as biographical value. Nevertheless, as we have seen, it was not without its critics and there remain an unsettling number of scholars and critics who refuse to engage with Hughes or Birthday Letters in any meaningful way. Feminist readers of Birthday Letters were not its only detractors. One of Hughes's most long-standing supporters, the critic Keith Sagar (author of The Achievement of Ted Hughes (1978), Ted Hughes (1981) for the 'Writers and their Works' series, The Art of Ted Hughes (1983), and editor of The Challenge of Ted Hughes (1994)) has said that Birthday Letters should be considered a minor work within Hughes's oeuvre. In the second edition of The Laughter of Foxes (2000), Sagar complains that "the general impression built up by the media over many years... [is] that Hughes's greatest

\footnotetext{
66 'Ariel's Gift'. 10

${ }^{67}$ Germaine Greer on Close Up, BBC TV. December 1998, quoted in: ‘Ariel's Gift'. 11.
} 
claim to fame was as the husband of Sylvia Plath."68 Sagar also claims that Birthday Letters and Hughes's translation Tales of Ovid are both artistically limited because they revisited existing narratives that did not allow Hughes full creative freedom:

Ironically, the two works that have received most of [Hughes's] belated acclaim, Birthday Letters and Tales of Ovid, are not part of the main body of Hughes's achievement, since, splendid as they are of their kind, neither allowed Hughes the total imaginative freedom his greatest work needed, each being Hughes's treatment of already existing material, whether Ovid's tales or the already welldocumented factual record of his relationship with Sylvia Plath. In both works the plot was predetermined. ${ }^{69}$

Sagar suggests that Hughes's earlier sequences Cave Birds (1975) and Remains of Elmet (1979) were more successful poetic sequences because in these Hughes enjoyed complete imaginative freedom. This view is unlikely to have been shared by Hughes, however, who suggested to a student correspondent, Jennifer Habel, that Cave Birds and Remains of Elmet were among his least accomplished works and had distracted him from more "serious endeavours":

After a while, of course, it dawns on you that those collaborations [with artist Leonard Baskin in Cave Birds and photographer Fay Godwin in Remains of Elmet], like anything else, have taken up their years, and whether you like it or not other people read them as your serious endeavours... I think I might have written [Cave Birds] differently. At one point I did set up a whole workshop of notes etc to rewrite it entirely but - time, other projects etc, interfered. Andvarious critics wrote at considerable length about the book - I felt reluctant (idiotic, I admit) to make all their efforts redundant. So finally I let it lie. ${ }^{70}$

\footnotetext{
68 Sagar, Keith. The Laughter of Foxes: A Study of Ted Hughes. $2^{\text {nd }}$ revised edition. Liverpool: Liverpool University Press, 2006.. ix-x. Hereafter referred to as 'The Laughter of Foxes'.

69 'The Laughter of Foxes'. $\mathrm{x}$.

70 'Emory'. Ted Hughes Collection. Box 54. FF1. [Letter from Ted Hughes to Jennifer Habel on 1 November 1993]
} 
Hughes wrote this letter to Habel in 1993, when he had, presumably, written many of the Birthday Letters poems. His comments suggest a re-evaluation of the heavily symbolic poetic in his earlier work such as Cave Birds, following his more open first-person address in the Birthday Letters poems. Hughes's comment that "various critics wrote at considerable length" about his earlier books also suggests a motive for Sagar's hesitancy in disturbing the established hierarchy in the Hughes canon. For it is difficult to accept Sagar's claim that a "well documented factual record" of his relationship to Sylvia Plath already existed prior to Birthday Letters, or that Birthday Letters itself should be seen as a "factual record" of that relationship. Sagar's dismissal of the volume ignores Hughes's battle over the years for the possession of 'the facts of his life'. In his private letters, Hughes repeatedly complained of the "fantasies" in this "record" of his relationship to Plath. Moreover, the very idea that a subjective narrative could offer a "factual record" goes against the Romantic vision Sagar attributes to Hughes elsewhere in The Laughter of Foxes. Like many of Hughes's detractors, the usually admiring Sagar appears to have judged Birthday Letters on autobiographical rather than aesthetic grounds. His low opinion of Birthday Letters may relate to the trivial way the book has been popularly consumed, as Alvarez complained in 2005:

Ted Hughes's Birthday Letters probably became a best-seller not because of the beauty and power of his language, but because people wanted the low-down on his marriage to Plath. ${ }^{71}$

Since the publication of Birthday Letters, and Hughes's death, interest in the story behind the book has continued unabated and new interpretations of the lives therein, must now contend with the subjective drama of Hughes's Birthday Letters, along with the subjective drama in Plath's poetry, for possession of the story they tell.

Emma Tennant's controversial memoir Burnt Diaries (1999) re-ignited interest in Hughes's story with an exposé 'kiss and tell' account of her affair with Hughes in the 1970s. In 2001, Elaine Feinstein published Ted Hughes: The Life of a Poet, an

\footnotetext{
${ }^{71}$ Alvarez, Al. The Writer's Voice. London: Bloomsbury Publishing. 2005. 114.
} 
unauthorised but sympathetic biography of Hughes. That same year, the accusation that Hughes suppressed Plath's intentions in Ariel was revisited in Lynda Bundtzen's book The Other Ariel. Not surprisingly, the Plath estate refused Bundtzen permission to reproduce Plath's poems in her book, which prompted the obligatory notice of defiance via the book's foreword:

In writing this preface I become part of a tradition in Plath scholarship, a member of a group of scholars, biographers, and critics who have been discouraged by the executors of the estate of Sylvia Plath (and now the estate of Ted Hughes) from pursuing their research, scholarship, and interpretations. It is a distinguished company, including Jacqueline Rose, Linda Wagner-Martin, and Anne Stevenson among others... The expectation is that one's interpretations are open to disagreement, that there is a 'free marketplace' of ideas, and that not everyone will want to "buy" a single scholar's work as definitive. My understanding of the thinking of the unidentified 'we' at Faber and Faber and the collective estates is that I should not have access to the marketplace of ideas because they disagree with me. ${ }^{72}$

It is interesting to note that since the publication of Birthday Letters the tendency to fictionalise Plath's and Hughes's historical life has become more pronounced. It is as though with Birthday Letters Hughes has established that if any attempt at autobiographical record is a subjective and fallible exercise, then a fictional account must be equally valid. In 2001, Emma Tenant's Sylvia and Ted: A Novel provided readers with another fictional 'interpretation' of the marriage. The year 2003 saw the publication of Kate Moses's fictional account of Plath's last months in Wintering: A Novel of Sylvia Plath, and the British motion picture Sylvia was released, starring Gwyneth Paltrow and Daniel Craig. When interviewed about making the film, director Christine Jeffs said that she felt as though she had permission to tell the story after Hughes had finally addressed it in Birthday Letters. ${ }^{73}$ Indeed, Sylvia appears to thread together a cautious narrative that

\footnotetext{
${ }^{72}$ Bundtzen, Lynda K. The Other Ariel. Massachusetts: University of Massachusetts Press, 2001. vii-viii

${ }^{73}$ Interview with Alison Owen. "A Hard Act to Follow", BBC Radio 4, 09.09.1999.
} 
contradicts neither Hughes's nor Plath's accounts and, in its pedestrian objectivity, fails to offer any insight into its central characters.

In 2002, Jillian Becker published her memoir of Plath and Hughes Giving up: The Last Days of Sylvia Plath, in order to dispel some of the myths that had arisen:

I'd better set down my memories of Sylvia Plath while I still have them. I gave some to biographers, but they suppressed the information or distorted it, not only with inaccuracies but also by tailoring it to make a point. ${ }^{74}$

Despite Becker's assurance that her memoir provides the true unmediated story, Giving $U p$ amounts to little more than a collection of trivial anecdotes and strong opinions. Her comments on Hughes's and Plath's poetry betray a shallow appreciation of both writers' work. Becker criticises Birthday Letters for its fatalism and is critical of Plath's mythmaking too. Plath, she points out, was quite different from her self-portrayal in her writings:

Perhaps Sylvia Plath the feminist will fade away as intellectual fashions change. But another myth has been growing since Hughes died in 1999 [sic], or perhaps since he published his Birthday Letters. It is the Ted Hughes - Sylvia Plath myth, of two great poets locked together in a Wagnerian clinch that is at once an embrace of passionate love and an anguished struggle to the death. ${ }^{75}$

Becker condemns Hughes's mythopoeia in Birthday Letters as propagandistic, and, on the same grounds, suggests that Plath's suicide was an act of violence "dedicated to posterity":

She left no last-minute scribbled note to Hughes, but she left him her poetry, knowing he would understand those last poems as suicide notes, not apologetic

\footnotetext{
${ }^{74}$ Becker, Jillian. Giving Up: The Last Days of Sylvia Plath. New York: Ferrington, 2002. 1. Hereafter referred to as 'Giving Up'.

75 'Giving Up'. 72-3.
} 
but accusatory. Her death itself was addressed to him, and through him to the world... She probably saw that she could accomplish recognition as a contributor to English literature better by dying than living - once the poems were written and neatly typed on clean paper...Fame was her last desire as it had been her first. Her Letters Home are as much addressed to posterity as are Birthday Letters. $^{76}$

Despite her formidably opinionated tone, Becker's approach to Hughes's and Plath's lives is interesting in that she refuses to accept the 'myths' that have grown up around the two. She portrays the couple as ordinary and fallible and her criticisms are delivered at both poets on a personal, rather than an artistic, level. Hughes is criticised for his infidelity (which she sees as a biologically driven male trait) and Plath is criticised for leaving her children orphans in order to authenticate the suffering described in her poems. It is perhaps due to the author's intimacy with Hughes and Plath that she is able to consider the poets in their most quotidian aspect, a perspective unavailable to the readers of their poetry.

In 2004, Frieda Hughes released Ariel: The Restored Edition, restating her mother's original selection for the Ariel sequence. The book included a facsimile of Plath's manuscript including typing errors, corrections, and a number of drafts for several of the poems. In a poignant foreword Frieda questions the almost religious martyrdom that had been awarded to her mother because of her suicide, which had at times made her question the nature of her mother's celebrity: "I did not want my mother's death to be commemorated as if she had won an award. I wanted her life to be celebrated..."77 Frieda emphasises the artistic value of her mother's work and insists on the need for readers to separate the speakers of Ariel and Sylvia Plath the author, who was much more than the personae of the poems she wrote in the last months of her life:

When she died leaving Ariel as her last book, she was caught in the act of revenge, in a voice that had been honed and practiced for years, latterly with the

\footnotetext{
76 'Giving Up'. 73.

${ }^{77}$ Hughes, Frieda. 'Foreword'. In: Plath, Sylvia. Ariel: The Restored Edition. New York: Harper Collins, 2004. xx. Hereafter referred to as 'Ariel: The Restored Edition'.
} 
help of my father. Though he became a victim of it, ultimately he did not shy away from its mastery. ${ }^{78}$

Frieda's introduction is useful in the same way as Becker's Giving Up in that it pleads for a sober reconsideration of her parents' lives and their work. Such an approach was taken in Diane Middlebrook's Her Husband (2004) a study of Hughes's and Plath's lives that foregrounds both of their mythmaking tendencies. Her Husband takes its title from the third-person pronoun Hughes adopted when he attempted to write about Plath in his essays as an impartial objective critic. Middlebrook suggests that Hughes adopted a mythic persona, as a means to protect his personal story from others. Middlebrook, like Becker, sees Hughes's mythopoeic framing of his life as being motivated by Plath's death and as being aimed at posterity but suggests that Plath's inventions and reinventions of self in her writings are creative and self-therapeutic rather than deceptive. Her Husband is useful for the present study because Middlebrook surveys the way that Hughes's and Plath's historical identities have been consumed by the mythic personae they selfconsciously created in their writings. However, in the final chapter of this study I will be arguing that Hughes's mythopoeia in Birthday Letters was also a cathartic act of healing, through which he recovered his private impressions and experiences of his marriage to Plath.

Ann Skea has recently completed a detailed study entitled Birthday Letters: Poetry and Magic which is, at present, only available electronically online. ${ }^{79}$ Skea argues that Birthday Letters is structured according to traditional mythopoeic and archetypal symbols. As in the present study, Skea argues for a mythopoeic understanding of the drama in Birthday Letters drama and symbols of mythology to unlock meaning from Hughes's text. However, Skea argues that the overarching structure of Birthday Letters follows a cabbalistic pattern that she explains with reference to the correlation of the Cabbalistic Tree of Life and the traditional Tarot pack. Although Skea provides fascinating readings of much of Hughes's symbolism, her suggestion that the Birthday

\footnotetext{
78 'Ariel: The Restored Edition'. xviii.

${ }^{79}$ Ann Skea's Poetry and Magic can be found at: http://ann.skea.com/BLCabala.htm.
} 
Letters sequence is ordered according to a cabbalistic pattern is unsettled by the existence of an early typescript of Birthday Letters among Seamus Heaney's papers at the Emory University archives in Atlanta. This typescript indicates that Hughes's original sequence was different to the one finally presented in Birthday Letters. Hughes's editor at the time of Birthday Letters, Christopher Reid, has confirmed that the typescript at Emory was the version of Birthday Letters originally submitted to Faber by Hughes in $1997 .^{80}$ This earlier sequence of Birthday Letters included two other poems, 'The Laburnum Tree' (which later became 'Night Ride on Ariel') and 'The Leopard Skin' (which was removed from the Birthday Letters sequence). According to Erica Wagner, these two poems were also included in the typescript originally sent to The Times for serialisation prior to the publication of Birthday Letters.

The only book-length study of Birthday Letters is Erica Wagner's Ariel's Gift: The Story of Birthday Letters (2000), a book that, as the title suggests, is a biographical exploration of the sequence. Wagner's analysis is informed and comprehensive but offers itself primarily as an introduction for the general reader. Given that Ariel's Gift was authorised by the Hughes estate it has, somewhat predictably, been described as a 'sanitised' companion to Birthday Letters. For some critics, Wagner is simply too accommodating of Hughes in the way she uncritically accepts his version of the Birthday Letters story. Nevertheless, despite the biographical focus of Wagner's project, she makes a clear distinction between Birthday Letters and the biographical events it describes:

There is nothing final about Birthday Letters. In the first place it is not a memoir, that most fallible of endeavours, but a work of art, and the nature of art is infinite. Poems - by Ted Hughes, by Sylvia Plath, by any poet - may be linked to events, but they are not those events; they are themselves. Nearly drowning out the

\footnotetext{
${ }^{80}$ Conversation with Christopher Reid, Wellington, 2009. [The Birthday Letters typescript at Emory contains Mr Reid's annotations made while he was Hughes's editor.]
} 
voices of these two poets are the many voices of those who knew these two poets, who have their perceptions, too, of what was 'really' going on at this moment. ${ }^{81}$

Wagner's distinction between art and autobiography, between events and the apprehension of and representation of events, is crucial for any meaningful approach to Birthday Letters and it appears that critics have already begun to wrestle with the imaginative terms of Hughes's mythopoeia in the sequence. These readings help introduce the area to be explored within this thesis. In Lynda Bundtzen's "Mourning Eurydice: Ted Hughes as Orpheus in Birthday Letters' (2000), she complains that Birthday Letters has "received very little interpretation based primarily on literary values" 82 and suggests a different critics approach the sequence differently:

An alternative critical strategy begins by simply acknowledging the fictive means of such assertions and then looks for a consistent patterning of poetic statements that offers an invented truth about what happened in their marriage. Hughes's Birthday Letters are embedded with myth, folklore, with references to other poems, many of them by Plath, and they display an inordinate degree of literary self-consciousness... he is engaging his wife's pre-occupations with honeybees and Otto Plath, with the figure of Ariel and the other dramatis personae from Shakespeare's Tempest, and with Plath's overarching themes of death and rebirth, mourning and melancholia. Birthday Letters are both companion poems and adversarial poems, in conversation and argument with Plath as a fellow poet of grief and as the irretrievable wife, Eurydice, to Hughes's Orpheus. ${ }^{83}$

Bundtzen illustrates an insightful parallel between the story of Birthday Letters and the myth of Orpheus and Eurydice. She identifies "an implicit analogy between Hughes and Orpheus" ${ }^{\prime 84}$ and point out that, in 'A Picture of Otto', Hughes goes into the underworld to ask Otto Plath for her daughter. A similar approach to Bundtzen's is provides in Jon

\footnotetext{
81 'Ariel's Gift'. 13.

${ }^{82}$ Bundtzen, Lynda. "Mourning Eurydice: Ted Hughes as Orpheus in Birthday Letters." Journal of Modern Literature 23.3 (2000): 457. Hereafter referred to as 'Mourning Eurydice'.

83 'Mourning Eurydice'. 458.

84 'Mourning Eurydice'. 458.
} 
Stallworthy's essay, 'With Sorrow Doubled'(1999). Stallworthy argues that the myth of Echo and Narcissus works as a structural principle in Birthday Letters. Plath is Narcissus, and Hughes is Echo her mourning lover. Birthday Letters, Stallworthy argues, echoes the utterances of Plath in order to challenge, re-contextualise, and simply celebrate her words. ${ }^{85}$ Hughes's echoing of Plath has also been the focus of Susan Bassnett's chapter on Birthday Letters in her introductory book to Plath's poetry. Bassnett suggests that in revisiting and re-contextualising Plath's words, Birthday Letters can be seen as a 'translation' and thus resurrection of Plath's words:

Translation ... offers a continuation of life to an original text, enabling that text to reach a new generation of readers in another place and another time. The idea of translation as after-life, as continuation, perhaps even resurrection is a powerful one, and one that sees the activity as essentially life-enhancing. Hughes, in Birthday Letters, gives us a version of Plath's life and writing that can truly be described as life enhancing, for he gives new life to her reputation, as a poet and as a human being. ${ }^{86}$

This idea of Birthday Letters as translation, as 'after life' or 'resurrection', fits very well with Hughes's notion that poetry was a primitive kind of magic, and he often compared the role of the poet to that of the shaman; both undertook imaginative cathartic journeys in order to heal themselves and their tribe. Accepting Hughes's unusual notion of poetry, we will find that Birthday Letters is an imaginative journey in which Hughes

\footnotetext{
${ }^{85}$ Hughes's mythic strategies have already been explored in a number of books that, being published before Birthday Letters, do not account for the sequence such as Stuart Hirschberg's Myth in the Poetry of Ted Hughes (1981), Terry Gifford and Neil Roberts' Ted Hughes: A Critical Study (1981), Ann Skea's The Poetic Quest (1994), and Paul Bentley's The Poetry of Ted Hughes: Language, Illusion and Beyond (1998). These studies uncover and examine in detail a frequency of instances where Hughes has used mythical patterns to structure both individual poems, and entire sequences throughout his oeuvre. They also examine Hughes' mythopoeia in relation to belief in the correlation between shaman and poet, and view of poetry as offering shapes for psychic catharsis.

${ }^{86}$ Bassnett, Susan. 'Plath Translated: Ted Hughes's Birthday Letters'. Sylvia Plath: An Introduction to the Poetry. Hampshire: Palgrave Macmillan, 2005. 163. Hereafter referred to as 'Plath Translated'.
} 
1 Introduction

attempts to recover himself and Plath from the roles imposed upon them by the myth, as he says in 'Suttee', "That sucked the oxygen out of both of us" (BL.149). ${ }^{87}$

${ }^{87}$ Hughes, Ted. Birthday Letters. London. Faber and Faber. 1998. 149. Hereafter referred to in parentheses in the text: e.g. (BL.149) 


\section{Myth}

Throughout this study I will be analysing the way Hughes uses myth in Birthday Letters to record and make sense of his and Sylvia Plath's experiences. Therefore it is important to clarify exactly what I mean when I talk of 'myth'. These days the term is most commonly understood as a synonym for falsehood, a widely-held false belief, a fiction, a delusion. We are often faced with newspaper articles and television programmes that purport to 'explode' myths through rational explanation. This notion of myth as a falsehood helps us to understand the attitudes of those reviewers of Birthday Letters, such as Pollitt and Wood, who strongly object to Hughes's mythopoeia ('myth making') because they feel that such elements damage the veracity of the narrative and its value as 'truth'. However, as I stated in the introduction, we should not simply judge Birthday Letters in terms of its autobiographical content. It is a work of art in which myth is used as a means of exploring the subjective, 'inner' element of the characters' experiences, as Hughes attempts to make sense of, and come to terms with, these experiences, by creating a story from them.

Hughes's lifelong interest in myths and folktales is well documented and is evident in his writings prior to Birthday Letters and in the translations published after his death. Having studied English, anthropology and archaeology at Cambridge, Hughes would have known that the word 'myth' is derived from the ancient Greek mythos and that, for the ancient Greeks, mythos performed many vital functions in society. Mythos offered the ancient Greeks dramatic depictions of subjective human experience and coherent explanations for mechanisms of the outer world. It provided a dramatic imaginative form to make sense of the inner-world of instinct, desire and emotion, and was an imaginative stage to celebrate or to challenge traditional values. Mythos also explained the mystery of origins, birth and death, and illustrated why all things had come to be this way.

For Homer and the early Greek poets, mythos meant literally 'words' and signified 'a pleasing arrangement of words' in a literary sense; it meant a particular register. Plato considered mythos to be an art of language alongside, and including, poetry. $\mathrm{He}$ 
understood mythos as a persuasive type of discourse that contained its own particular kind of intuitive 'truth'. In the Republic, he argued that poets were dangerous and should be regulated. The persuasive power mythos wielded upon its audiences meant it could be used or misused as a political tool. ${ }^{88}$ Nevertheless, as Hughes points out in his essay 'Myth and Education' (1976), Plato still believed that children should be taught myths at school because, according to Hughes, Plato recognised that myths are 'units of imagination' and that, in imaginatively reconciling the elements in the story, the child would be initiated into the beginnings of imagination and mental control. ${ }^{89}$

Plato's pupil, Aristotle, in his Poetics, offered another useful definition of myth. He made a distinction between two Greek terms that both meant 'words': mythos and logos. He associated logos with the 'story' - the facts and history that are treated by a play, and associated mythos with the dramatic treatment of the story - the artistry, plot, and the revealed truth. Aristotle believed that the poet's role was to unveil the 'higher', 'universal' truths of experience that objective, historical accounts could not provide:

The poet's function is not to report things that have happened, but rather to tell of such things as might happen, things that are possibilities by virtue of being in themselves inevitable or probable... Poetry, therefore, is a more philosophical and a higher thing than history, for poetry tends to express the universal, history the particular. $^{90}$

For Aristotle, the poet's role is not the reporting of an event as it happened in objective reality, but to make sense of the event, or a series of events (i.e., a story), and to provide the events with meaning and significance. Aristotle's distinction is helpful when considering Hughes's use of myth generally and particularly in Birthday Letters. As an autobiography, Birthday Letters is logos in that it contains historical facts and events

\footnotetext{
${ }^{88}$ Despite this, Plato still resorted to myths when his rational discourse needed to be amplified emotionally or aesthetically, or when his logical discourse exhausted rather than elucidated his ideas. A collection of Plato's myths is available in: Partenie, Catalin. Ed. Plato: Selected Myths. Oxford: Oxford World's Classics, 2004.

${ }^{89}$ Hughes, Ted. 'Myth and Education'. [1976] Winter Pollen: Occasional Prose. London: Faber, 1994. 138-9. Hereafter referred to as 'Winter Pollen'.

${ }^{90}$ Hutton, James. Trans. Aristotle's Poetics. New York: W.W. Norton, 1982. 54.
} 
about Hughes's and Plath's lives. On these grounds, the value of Birthday Letters can be judged in terms of the accuracy, veracity, and objectivity of the events related. However, Hughes's treatment of these facts, his re-visioning of events within a subjective poeticdrama, means that the poems are clearly better understood as mythos. In Birthday Letters, Hughes is not attempting an autobiography in a historical sense; he is attempting to come to terms with, and make sense of, the tragic events he relates. To read Birthday Letters as mythos we need to abandon any prejudicial notion of myth as false-belief, as a 'primitive' explanation for human experience and nature. This is arguably a notion we have inherited from the early Christian church, which privileged its monotheistic singular Logos (with a capital 'L') over the pagan mythoi it contended with for the truth. The Church dismissed the pagan myths as misguided fictions that were at odds with, and inferior to, its singular Truth. Following centuries of theosophical struggle to reconcile Biblical interpretations and theosophical assertions with the emerging demonstrable scientific evidence, the Church lost much of its credibility as our instrument of Truth. The objective scientists are our modern high priests of Truth, our contemporary agents of Logos.

But Hughes is not attempting an objective record in Birthday Letters. He should be understood as a late Romantic poet whose writings offer a critique of the 'objective ideal' as an inadequate model to cater for the truth of experience. In 'Myth and Education' (1976), he argued that reality is the simultaneous experience of our inner and outer worlds. The outer world is the individual's wakeful, conscious, observing self, and the inner world is the world of the subject's unconscious, instinctual and emotional life. Human experience, Hughes argues, is a complex and simultaneous mixture of signals from both the inner and outer world; indeed, the individual is nothing more than the locus where these two worlds meet. In 'Myth and Education', Hughes complained that the powerful scientific objective ideal of the past 300 years has caused us to identify wholly with our outer 'objective' world and ignore the signals from our inner world. He believed that this over-identification with the objective outer world has resulted in a narrow mode of perception that has alienated the individual from his inner world, impoverishing our understanding of ourselves and our 'true' relationship with the outer 
world. Having ignored these subjective experiences for so long, we have become deaf to many of the signals from the inner world, or, if we do hear them, we do not know how to interpret them. For Hughes, this amounts to a denial of the essential aspect of our humanity:

The word 'subjective' was invented for a good reason - but under that vaguest of general terms lies the most important part of our experience. ${ }^{91}$

In 'Myth and Education', Hughes argued that the 'human spirit' is not a "mechanical business of nuts and bolts" and cannot evolve into such "just because a political or intellectual ideology requires it to". ${ }^{92}$ He suggested that the objective ideal of the modern world has become so powerful that it has materialised into a machine of scrupulous observation - the camera, which, passively records everything it beholds, all things being equally important and equally unimportant. Characteristically, Hughes uses a story to illustrate his ideas and issue a warning about this kind of inattentiveness to the inner world:

Some years ago in an American picture magazine I saw a collection of photographs which showed the progress of a tiger killing a woman. The story behind this was as follows. The tiger, a tame tiger, belonged to the woman. A professional photographer had wanted to take photographs of her strolling with the tiger. Something - maybe his incessant camera - had upset the tiger, the woman tried to pacify it, whereupon it attacked her and started to kill her. So what did the hero of the story do then? ... Whatever his thoughts were he went on taking photographs of the whole procedure while the tiger killed the woman, because the pictures were there in the magazine. And the story was told as if the photographer had indeed been absent. As if the camera had simply gone on doing

\footnotetext{
91 'Winter Pollen'. 149.

92 'Winter Pollen'. 149.
} 
what any camera would be expected to do, being a mere mechanical device for registering appearances. ${ }^{93}$

Through this story, Hughes argues that an objective model of reality is inadequate to cater for human experience because its prevailing morality "is utterly devoid of any awareness of the requirements of the inner world."94 For Hughes, the outer world does not exist beyond our participation, and even though it is difficult to observe our inner world, which has resulted in it being deemed "untrustworthy", it still contains the closest, most insistent part of our sense of reality - the vitally authentic and human element of our experiences. Hughes argued that science cannot get us any closer to our true self, because our inner world is not available for objective observation. However, there is another, older machine available that can tell us about our inner-world, and that is the 'story'.

For Hughes, the imagination is the faculty that embraces both the inner and outer worlds simultaneously, and stories are "little factories of understanding" that provide a landscape for the human imagination to live in, navigate, and explore ideas and the nature meaning and significance of experience. When a person learns a story and becomes familiar with its patterns, characters, and its drama, he can re-enter the story and reconsider its implications at leisure. This is the beginning of mental control, the beginning of imagination, and the beginning of contemplation. The imagination, he points out, is not an instrument exclusively for poets and artists but "the toolbox for everything we do", including science. He suggests that when a story is learned well, its whole pattern and images can be reduced to a word through which the individual can reexperience the pattern of the entire story:

If the story is learned well, so that all its parts can be seen at a glance, as if we looked through a window into it, then the story has become like the complicated hinterland of a single word. Any fragment of the story serves as the 'word' by

\footnotetext{
93 'Winter Pollen'. 146-7

94 'Winter Pollen'. 146
} 
which the entire story's electrical circuit has been switched into consciousness, and all its light and power brought to bear. As a rather extreme example, take the story of Christ. No matter what part of the story we touch, the whole story hits us. If we mention the Nativity, or the miracle of the loaves and fishes, or Lazarus, or the Crucifixion, the voltage and inner brightness of the whole story is instantly there. A single line is enough - just as you only need to touch a power-line with only the tip of a finger... A word of that sort has magnetised our life into a special pattern. $^{95}$

Stories are full of wisdom in the way they help us make sense of our inner experiences and provide an imaginative frame for the situations we encounter in the outer objective world, or the events we look back on. As we learn more stories, their narratives combine and increase the "complicated hinterland" of our imaginative space, our sense of self and our understanding of our relationships with others. Hughes argues that stories are magically cathartic in the sense that they can reconcile the needs of the hidden inner self and of the conscious ego-driven self, by uniting these two worlds through imaginative drama:

A simple tale, told at the right moment, transforms a person's life with the order its pattern brings to incoherent energies. ${ }^{96}$

Knowing a story, or being preoccupied with a story, provides the imagination with a limited scope of options to map out possible resolutions to problems. When the individual knows several stories, this imaginative space becomes more complicated and the possible resolutions multiply. Hughes argues that when a word like "crucifixion" is combined with another word, such as "Hitler", (for example in the phrase "the crucifixion of Hitler") the two stories we associate with these words collide in the imagination and must reconcile their differences in some way:

\footnotetext{
95 'Winter Pollen'. 139.

96 'Winter Pollen'. 153.
} 
For some temperaments, these two words twinned in that way may well point to wholly fresh appraisals of good and evil and the underground psychological or even actual connections between them. Yet the visible combatants here are two stories. $^{97}$

Although the stories of 'Christ' and 'Hitler' are extreme examples in their associations with our cultural values of 'good' and 'evil', they are also an interesting parallel in terms of the contending figures in Hughes and Plath's myth. In Plath's poems we encounter Hughes as "a man in black with a Meinkampf look" (SPC.224) and Plath as "a Jew" (SPC.223), the victim martyr who suffers at the hands of the tyrant.

Hughes called stories "units of imagination" which, by combining with experiences, and other stories, help us to make sense of our experiences and emotions. What Hughes believed is most impressive about stories is that they do not require our wakeful intervention in order to reconcile themselves to one another, and work out conclusions. Through their inter-connections and metaphorical correlations, the stories appear to create meaning autonomously, without our conscious intervention. Returning to the stories of 'Christ' and 'Hitler', Hughes argues:

What these two stories show very clearly is how stories think for themselves, once we know them. They not only attract and light up everything relevant in our own experience, they are also in continual private meditation, as it were, on their own implications. They are little factories of understanding. New revelations of meaning open out of their images and patterns continually, stirred into reach by our own growth and changing circumstances. ${ }^{98}$

In 'Myth and Education', Hughes goes so far as to argue that the sudden achievements of classical Athens emerged from an unprecedented clash of stories, as the mythologies of neighbouring tribes and countries attempted to reconcile their differences.

\footnotetext{
97 'Winter Pollen'. 140.

98 'Winter Pollen'. 141.
} 
At the beginning of the first millennium $\mathrm{BC}$, he advises, the myths from neighbouring lands began to converge on Greece, "from Africa via Egypt, from Asia via Persia and the Middle East, from Europe and from all the shores of the Mediterranean", 99 creating "the battleground of the religious and mythological inspirations of much of the archaic world":

The conflict was severe, and the effort to find solutions and make peace among all those contradictory elements was correspondingly great. And the heroes of the struggle were those early philosophers. The struggle created them, it opened the depths of spirit and imagination to them, and they made sense of it. What was religious passion in the religions became in them a special sense of the holiness and seriousness of existence. What was obscure symbolic mystery in the mythologies became in them a bright, manifold perception of universal and human truths. In their works we see the transformation from one to the other taking place. And the great age which immediately followed them, in the fifth century $\mathrm{BC}$, was the culmination of the activity. ${ }^{100}$

The sudden flourishing of civilisation in Athens was, in Hughes's view, the result of the imaginative effort required to reconcile the clash of these opposing mythologies. He also believed that these imaginative epiphanies could occur within the mind of an individual, and suggested that "the head that holds many stories becomes a small early Greece". ${ }^{101}$

In Birthday Letters we encounter just such a clash of stories in which Hughes contends with a compendium of dramatic events and images drawn from Plath's writings, from her biographers, and from folklore and myth. By fusing these stories together, Hughes asks the stories themselves to divine the truth of his experiences, and in Birthday Letters he offers the reader a vision of how he has personally interpreted his history through stories in this way. In fusing stories together in Birthday Letters, Hughes is not attempting to reveal some objective truth about Plath and her writings. His interpretation

\footnotetext{
99 'Winter Pollen'. 137.

100 'Winter Pollen'. 138.

101 'Winter Pollen'. 141.
} 
of her writings and behaviour is subjective, provisional and fallible as are his readings of other poets. Birthday Letters contains interpretations rather than explanations of what happened.

So much for stories, but when does a story qualify as a myth? In 'Myth and Education', Hughes argues that a myth is a special kind of story that has cathartic psychic properties because it provides an image, a symbol, or a drama, of our inner world's chaotic energies reconciled with our outer world:

A story that engages, say, earth and the underworld... contains not merely the space and in some form or other, the contents of these two places; it reconciles their contradictions in a workable fashion and holds open the way between them. $^{102}$

Myths are simply stories or poems that provide an image or dramatic account of our inner and outer worlds in balance, myths are the narrative equivalent of the mandala, and through them we can discern the significance of our experience, of our actions and our place in the world. The visions contained in myths have been called divine, religious, mystical or, as Hughes commonly calls them, visionary. According to Hughes, this is the quality that all great art, and poetry in particular, aspires to:

The character of great works is exactly this: that in them the full presence of the inner world combines with and is reconciled to the full presence of the outer world. And in them we see that the laws of these two worlds are not contradictory at all; they are one all-inclusive system; they are laws that somehow we find it all but impossible to keep, laws that only the greatest artists are able to restate. $^{103}$

\footnotetext{
102 'Winter Pollen'. 138-9.

103 'Winter Pollen'. 150.
} 
For Hughes, myths are great works of art that have endured because in providing an image or drama that reconciles the demands of the inner and outer worlds, they cure us with their healing energies. Hughes believed that our ancestors had civilised, or had attempted to civilise, the archaic powers of instinct and feeling with myth and later with religion and the poet's role remains to find and gather these healing energies and heal his tribe. The audience of myth is not, like the reader of a science journal, simply presented with cold intellectual facts and argument but, like the sleeper, becomes involved in a drama that affects his whole imagination and visceral being. Hughes believed that, like dreams, myths were so integral to the human psyche that they operated on a primitive pre-conscious biological level. He suggested that what has been described as our "great liberation" from myth and religion, in our conversion to objective science, has resulted in our inner world being abandoned, "ailing in its own deprivation". ${ }^{104}$

Hughes argued that the objective ideal of the modern world's denial of the inner world meant that when Freud's psychoanalysis discovered the inner world, at the turn of the twentieth century, it was in a state of turmoil:

As the religion was stripped away, the defrocked inner world became a waif, an outcast, a tramp. And denied its one great health - acceptance into life - it fell into a great sickness... The whole inner world has become elemental, chaotic, continually more primitive and beyond our control. It has become a place of demons... Down there, mixed up among all the madness, is everything that once made life worth living. All the lost awareness and powers and allegiances of our biological and spiritual being. ${ }^{105}$

Freud and Jung were influential to Hughes's and Plath's notions of what myths are and how they could use them in their own writings. Therefore a survey of these founding psychoanalysts' ideas is useful and will help us understand how Hughes responds to Plath's mythopoeia in Birthday Letters.

\footnotetext{
104 'Winter Pollen'. 149.

105 'Winter Pollen'. 149.
} 
Freud and Jung used myths to explain the psychological dramas of their patients' inner worlds. They had noticed how common themes, symbols, and dramas in their patients' dreams were also commonly represented in world mythologies. Noting the strong correlation between myths and dreams both concluded that myths were transhistorical expressions of the psyche, rather than simply historical records of objective events. Freud understood dreams as wish fulfilments, as the dramatic enactment of the dreamer's repressed desires. In experiencing the imaginative satisfaction of the repressed wishes, the energy connected to these repressed desires was harmlessly released and did not develop into a neurosis. Freud said that psychological disturbances (and thus the symbols in myths and dreams) were usually related to desires of a sexual nature and were generally linked to events repressed in childhood. By contrast, Jung believed that psychological disturbances related to all kinds of repressed energies and desires and were more commonly a reaction to the individual's present circumstances than to events in childhood. For Jung, dreams, and in the more extreme cases, psychological disturbances were evidence of the unconscious part of the psyche attempting to draw attention to its neglected demands (desires) and help restore balance between the individual's psyche (his inner and outer worlds). In other words, for Freud, the symbols of dreams and myths related to pathological aspects of the psyche, while for Jung, dreams and myths were part of the psyche's mechanism for healing itself.

Freud's influence on Plath is clear in her poem 'Daddy' and in the introduction she wrote for a BBC reading of the poem in 1962. Here she described 'Daddy' as "spoken by a girl with an Electra complex. Her father died while she thought he was God."106 Some critics have applied Freudian psychoanalytical theory to poems like 'Daddy' in order to 'diagnose' the author's ailment but it is important to remember that the dramas described in Plath's poems were not the unmediated expressions of her unconscious but a created work of art. Hughes's writings, and Birthday Letters in particular, are more informed by Jung's ideas about the psyche. Hughes understood

${ }^{106}$ Rosenthal, M.L. 'Sylvia Plath and Confessional Poetry'. In: Newman, Charles. Ed. The Art of Sylvia Plath. London: Indiana University Press, 1971. 70. 
Jungian therapy as "a means of putting human beings back in contact with the primitive human animal", ${ }^{107}$ and this was the cathartic task he attempted in his poems.

Hughes's ideas about the imagination and the function of poetry are evident in his critical writings on other poets. Hughes described Shakespeare, Blake, Coleridge, Keats, Yeats, Eliot, and Plath as 'visionary' poets whose work was deeply embedded in myth.

To use one of Hughes's favourite analogies for poetic inspiration, these poets had 'fished up' archetypal symbols from their unconscious in order to resolve some personal psychological crisis - though this subjective cure, in being archetypal, was often representative of some wider crisis of the poet's age. Hughes believed that when a poet's 'myth' had been identified (the key symbols or drama around which their writings constellated) the poems could be interpreted as an image of the poet's inner life. A visionary poem does not only contain a description of the crisis but demonstrates the poet's efforts, successful or unsuccessful, to resolve this drama. In his 1982 introduction to Plath's Journals, Hughes draws on Jung's description of the process of 'individuation' (the process of restoring balance between the unconscious and the ego; the inner and outer worlds) to interpret the underlying symbols and narratives he finds in Plath's writings. Again, Hughes emphasises that the poems were the result of, and a record of, an inspired, almost involuntary, cathartic process:

A Jungian might call the whole phase a classic case of the alchemical individuation of the self. This interpretation would not tie up every loose end but it would make positive meaning of the details of the poetic imagery ... Above all, perhaps, it would help to confirm a truth - that the process was, in fact, a natural and positive process, if not the most positive and healing of all involuntary responses to the damage of life: a process of self-salvation - a resurrection of her deepest spiritual vitality against the odds of her fate. And the Jungian

${ }^{107}$ Ted Hughes quoted in 'Her Husband'. 78. 
interpretation would fit the extraordinary outcome too: the birth of her creative self. 108

Hughes's description of the nature of Plath's inspiration and of her poems relies heavily on Jung's ideas about the psyche. Therefore an understanding of Jung's description of the psyche is helpful in order to understand Hughes's response to Plath's writings in Birthday Letters. Jung described the psyche as being divided into three parts: following Freud, he identified the 'ego' and associated it with consciousness, also the 'personal unconscious' that contained anything that is not presently conscious but which can be recovered - such as personal memories and perceptions. However, in addition Jung also suggested that there was a third aspect of the psyche, the 'collective unconscious', which he described as a reservoir of our ancestors' experiences: a psychic inheritance that is similar to our physical inheritance. Jung argued that the collective unconscious contains the memories of our ancestors that, without our knowledge, influence the way we experience and respond to everyday events, especially intuitive or emotionally charged experiences.

For Jung, the collective unconscious explained the correlations between spiritual or mystical experiences in various religions at different historical times, in the creative experiences described by great artists and musicians, and in the symbols and drama repeatedly encountered in dreams, fantasies, fairy tales and myths. He argues that the collective unconscious is governed by 'archetypes', which are psychic imprints that carry an unlearned tendency to experience things in a particular way. The archetype has no form of its own; it is, rather, an organising principle that arranges images, emotions, thoughts, behaviours, and experiences around itself. Archetypes are like black holes in space - we can only detect them from the light and matter they draw towards themselves. Jung argues that archetypes originated in repeated human experience over generations and had helped to direct behaviour into meaningful patterns to assist individuals in their journey through life. The unconscious nature of archetypes means they can never be

\footnotetext{
${ }^{108}$ Hughes, Ted. 'Sylvia Plath and her Journals'. [1982]. Winter Pollen: Occasional Prose. Faber and Faber. London, 1994. 181-2.
} 
directly encountered. We only know of their existence from observing the way they influence behaviour. An encounter with an archetype may be simply the feeling we have when we are moved by a work of art. Like Jung, Hughes believed the experience of an archetype is cathartic because it organises the psychic energies of our inner life. He believed that an encounter with a particular symbol or drama beneath which an archetype operated, at a particular moment in a person's life, could change the direction of that person's life. In this way, Hughes suggests that individuals are attracted to particular symbolic dramas that could be said to contain the story of their life and fate.

Hughes was familiar with the Jungian mythographer Joseph Campbell's Masks of God books ${ }^{109}$ in which Campbell offers some examples of how 'psychic imprints' affect behaviour in animals. As Hughes repeatedly points out in his poems, the experience of animals is not clouded by consciousness, and so, in observing their behaviour, we get an idea of how the archetypes work. Students of animal behaviour use the term "Innate Releasing Mechanism" rather than archetype to describe a psychic imprint that triggers a particular behaviour when stimulated by a sign or "a releaser". The releaser can be an image, a smell, a sound, or an event, so we do well to remember this when we think of archetypes as symbols. A well-known example of this automatically triggered behaviour can be seen in the hatched duckling that immediately after leaving the egg considers the first animal it sees as 'mother'. The newborn chick is unconsciously primed for the idea 'Mother' as a source of nourishment and protection from the start of its life. The newborn chick also darts for cover when a hawk flies overhead, but not when a gull or duck, heron or pigeon flies over its nest. Campbell points out that experiments have shown that when a wooden model of a hawk is drawn on a wire over a chick's coop the chick reacts as though the wooden hawk were real. However, if the same wooden hawk is drawn backward over the chick, it does not react to the stimulus.

\footnotetext{
${ }^{109}$ Hughes refers to these books in: Hughes, Ted. ed. 'Introduction: The Snake in the Oak'. A Choice of Coleridge's Verse. Faber: London, 1996. 12. Hereafter referred to as 'A Choice of Coleridge's Verse'.
} 
What these experiments demonstrate is an unlearned tendency to respond to a particular image but only when it moves, or behaves, in a particular way. ${ }^{110}$ They also suggest that an artificially constructed image, or a work of art that operates in a certain way, like a narrative, can trigger the same response. One other example is that of the grayling butterfly, whose behaviour indicates that a work of art may actually provoke a more intense response than nature, as Campbell explains:

The male of a certain butterfly known as the grayling (Eumenis semele), which assumes the initiative in mating by pursuing a passing female in flight, generally prefers females of darker hue to those of lighter - and to such a degree that if a model of even darker hue than anything known in nature is presented, the sexually motivated male will pursue it in preference even to the darkest female of the species. ${ }^{111}$

Campbell points out that the behaviour of the grayling butterfly demonstrates an instinctual inclination triggered by sign stimuli that is not actually satisfied in nature, but that may trigger the selection of mating partners if a new darker species appears in the future. In other words, this is an example of an unconscious type of behaviour that is stimulated more intensely by an artificial image (by art) than by anything that exists in the natural world.

For Hughes, the role of the artist, and the purpose of art, is to stimulate the innate psychic needs that remain unsatisfied in one's outer world. According to Jung, primitive humans, like animals, project the subjective contents of the collective unconscious (the archetypes) onto correlating objects in the outer world. It is not possible to list and describe each archetype in the collective unconscious because, apart from the fact that they are unavailable for objective observation, they often overlap, or exist in relation to other symbols and images. Nevertheless, Jung identified and described four major archetypes in detail - the mother, rebirth, the spirit, and the trickster. We will look

\footnotetext{
${ }^{110}$ Campbell, Joseph. The Masks of God: Primitive Mythology. New York: Penguin, 1976 [1959, 1969]. 43. Hereafter referred to ad 'The Masks of God'.

111 'The Masks of God'. 43.
} 
briefly at one of the most important archetypes - the mother, which, as we will see, is vital when considering Hughes's conception of poetic inspiration and his interpretation of Plath's writings (which we will look at in detail in chapter 5).

The presence of the mother archetype was explained by Jung as stemming from the fact that all of our ancestors had mothers. Compared to other animals, humans are particularly vulnerable in their early lives. The size of our brain and skull means we must be born while we are still dependent on our mothers for nourishment and protection. The child's psyche is unconsciously primed for the idea of a mother, and so all children are born expecting to have a dependent relationship with her. The mother archetype is, of course, projected from the child's unconscious onto the historical mother (or mother substitute). The child then expects the historical mother to fulfil the role of the mother archetype - to love, nurture, and protect. Although the child is not consciously aware of this expectation, he or she will experience a particular desire that is only satisfied by the mother's presence and, if the mother does not fulfil this role, the child will experience her absence.

Archaeologists have identified symbols of the mother archetype in the form of goddess figurines that represent some of the earliest relics of human culture, dating as far back as 20,000 BC and spread throughout Eastern Europe, Turkey, Palestine, Egypt, Mesopotamia, and the Indus Valley. ${ }^{112}$ Some 30,000 of these figurines have been found which emphasise the female body's biological creativity. From a wealth of evidence anthropologists have determined that a widespread Neolithic culture existed that through the symbol of the 'Mother Goddess', celebrated the drama of birth, the unmanifest becoming manifest, which it identified as the divine essence in the whole of nature and universe. The 'Mother Goddess' symbol was, from the earliest times, associated with not only the earth and nature but also the moon, which in its cycle of phases reflected the

\footnotetext{
${ }^{112}$ An example is provided in Appendix 1: 'The Goddess of Willendorf' (20,000-18,000 BC). Hughes refers to this particular artifact in the poem 'Remission' (BL.109)
} 
same divine drama of life, death, and rebirth. ${ }^{113}$ The recognition of a correlation between the cycle of life and the cycle of the moon would have given rise to the first myths, the first 'divine' narratives told by humans:

In the rhythmical phases of light and darkness the Palaeolithic tribes must have seen a pattern of growing and decaying endlessly renewed, and this would have given them trust in life. In the waxing of the moon they would have felt life growing and felt the growth of their own lives. In the full moon they may have marvelled at the increase of life that overflowed into new life. In the waning moon they would have mourned the withdrawal of life, the departure of the goddess; and in the darkness of the lost moon [which lasts three days] they would have longed for her return. With the passage of time, they must have come to trust in the reappearance of the crescent moon, and so to recognise darkness as the time of waiting before the resurgence of new life. With death they would have felt that they were taken back into the dark womb of the Mother and believed they would be reborn like the moon. ${ }^{114}$

It is possible that the moon, by which the longest measurement of time longer than a day (the sun) could be measured, may have enabled the development of abstract thinking. This is because, in calculating the cycles of the moon, early humans needed to include a fourth 'invisible' phase when the moon disappears for three days (its death). This would explain why early representations of crosses and swastikas are sometimes associated with the 'triple goddess' who is generally depicted in myths as a maiden, a pregnant woman, or an old hag or witch.

The most comprehensive Jungian description of mother archetype is provided by Erich Neumann, in his seminal study, The Great Mother (1955). Hughes referred to this

\footnotetext{
113 Appendix 2 shows the rock carving 'The Goddess of Laussel' (22,000-18,000 BC) a divine image of rebirth who is depicted as holding a crescent bison's horn notched with the thirteen days of the waxing moon and the thirteen months of the lunar year. With her left hand she points to her swelling womb. ${ }^{114}$ Baring, Anne and Cashford, Jules. The Myth of the Goddess. New York: Viking, 1991. 19. Hughes refers to this book in: 'A Choice of Coleridge's Verse'. 19.
} 
book in his 1996 introduction to a selection of Coleridge's poems. ${ }^{115}$ According to Neumann, the mother archetype, that he calls the Great Mother, is ubiquitous among early mythologies. Her names are numerous; she is, for example, 'Isis' (Egypt), Tiamat (Babylon), Ashtart (Syria), Inanna (Sumeria), Aphrodite (Greece), and so on. As the anthropomorphic Goddess of nature she performs the role of Great Mother on more levels of experience than any such image offered in nature itself, and can be seen as an organising principle for structuring life and experiences into meaningful images and narratives. She is often depicted as the 'Earth Mother' who, by nourishing the tribe, is understood as its mother. For the hunting tribes she was the mother of all animals, including humans, and so was responsible for the success of tribal hunting expeditions, as well as the success of predatory animals that prey on humankind. Prehistoric art often depicts female forms much larger than their male counterparts, denoting the female's importance within the tribe, and these females are often depicted holding their arms aloft, suggesting their magical function in ensuring the success of the hunt. From experience, these early tribes discovered that the goddess had her favourites whom she blessed and was neglectful of others. She was therefore worshipped and offered sacrifices in order to obtain her favour. The early agricultural tribes remained dependent on the Great Mother who also controlled the weather, gave birth to all living plants, and was responsible for the success or failure of harvests. Because of her ubiquitous nature, over time she accumulated a variety of symbols that were considered to contain her power (through sympathetic magic). A thorough examination of her attributes, which are spread over a multitude of cultures, would be voluminous and so in the following description I have limited myself to those of relevance to the present study. Again, the relevance of these attributes will become clearer when we look at Hughes's reading of Plath's poems in chapter 5 .

As we have seen, the Great Mother was experienced as the original divine presence, a state of the unmanifest from which the manifest emerged and so she was associated with the unconscious state of humankind from which consciousness emerged (or was born). She was associated with night and with darkness, the original state in all

115 'A Choice of Coleridge's Verse'. 96. 
primordial myths, and with the celestial bodies that appear in the night sky - in particular the moon. The apparent correlation between the moon and the female menstrual cycle strengthened the magical connection between the Goddess and the female creativity. This link is still preserved in our language: the Greek mene means moon, Latin mensis means month, and mensura, from which the name of the menstrual cycle comes, means 'measurement'. 116 Because the Great Mother is also the earth, everything that is on the earth is her. She is the trees, and the fruit and the flowers are her children. She is also associated with the stones, hence the various navel stone shrines celebrating the magic of the womb such as that at Delphi (which was originally the home of the Delphic Sibyl, a daughter of Lamia, but later housed the Pythia - a priestess of the male god Apollo). Because the womb or 'belly' is the locus of the goddess's creative magic, it was considered to be the seat of the emotions, which rise to cloud the loftier regions of the head.

In her positive creative aspect, the Great Mother was associated with birth and nourishment. The cow and the bee were therefore sacred to her, as were their products, milk and honey. As a symbol of birth, and of rebirth, the goddess was celebrated and her presence was welcomed. However, in addition to giving life to everything in the cosmos, she also takes life away. She is both creative and destructive by turns, and can be indifferent to the tribe's needs. An encounter with the Goddess was therefore often terrifying and in her negative aspect as the Goddess of Death her children, the animals and the plants, are only born to be killed in order to nourish her favourites.

Early man understood the Goddess as the quality in nature that turns blood to life, such as when the menstrual cycle stops and the female turns blood to life and then to milk to nourish her child. She therefore had a blood-thirsty reputation and was thought to exact blood for her gifts and for transgressions. Early humans attempted to appease her appetite for blood with human and animal sacrifice and her as sociation with stone and with the moon materialised everywhere in stone crescent-shaped sacrificial knives. Sympathetic magic was originally used to ensure success in the hunt and later to ensure

\footnotetext{
${ }^{116}$ Baring, Anne and Cashford, Jules. The Myth of the Goddess. New York: Viking, 1991. 18.
} 
the success of the harvest. Through these sacrifices, the Goddess was being asked to use her magic to turn blood into food.

The captured game or the harvest was therefore often depicted as her son, born from her earthy womb. The son, as an ear of corn, is then killed and eaten, only to be planted again in her womb and resurrected. In cosmological mythology the same drama was seen represented in the death of the star son who was invisible (thus died) at the moon's reappearance. In her negative aspect the Goddess was sometimes associated with the sow or the boar with its crescent tusks, who ate her young. Elsewhere she was associated with the lioness, which was protective of her young, but unpredictably destructive. Because she had power over life and death the Goddess was associated with Fate and in this aspect was often depicted as a spinsteress, weaving men's destinies from the fabric of her own body. Spinning wool was originally the business of women everywhere and Neumann argues that this was an example of social-order being influenced by mythological ideas. The Norse Valkyries were weavers, as were the three Fates, and Minerva appeared in ancient Greek myth as a weaver, for example, in the myth of Arachne. The Great Mother's weapon, as the Goddess (or triple goddess) of Fate, is the net, like that used by Clytemnestra, when she murdered Agamemnon as he stepped into his bath.

As the sacred power of the universe, the mother archetype was also identified with the unconscious invisible inspirations of the inner world, an idea that persisted in the Muse tradition. Jung believed that the fatalism expressed in myths demonstrated recognition, among early humans, that there was another autonomous agency directing human affairs - the unconscious.

According to Hughes, myths today still serve the same function they always have, in that they provide an image that, through the imagination, reconciles the inner and outer worlds and creates balance. As he said, "it does not matter... how old these stories are. Stories are old in the way human biology is old". 117 However, as Jung pointed out, the

117 'Winter Pollen'. 141. 
emphasis of these stories has changed somewhat. Whereas for early man, with his small ego, myths enabled the beginnings of imagination, contemplation, and human consciousness to develop, for modern man who has overly identified with his objective consciousness, myths call attention to the needs of his unconscious inner life.

Encounters with the archetypes are usually emotional, since our emotions are older and more primitive influences on our behaviour than rational thought. Jung suggested that the recognition of an archetype is often accompanied by a 'religious', 'ecstatic', and sometimes a 'terrifying' feeling, as the precious ego, with which we overly identify ourselves, is overwhelmed by the dynamic energies of the unconscious. Hughes was convinced that the 'truth' of experience lay beyond our rationally constructed reality. He believed that if we reacquainted ourselves with the primitive aspects of the psyche through the imagination, our experience of reality would be fuller and more profound. In a 1956 letter to Lucas Myers, he explained his notion that the final unequivocal aspects of experience were linked to the more primitive non-rational unconscious apparatus of the brain, which dealt with "inner" and "outer" experience explained why poetry written for the ear was so affecting:

The nerve from the ear, which was originally exclusively - as it still is partly - to do with the sense of balance \& movement, is connected directly to the Medulla the oldest part of the brain, which controls \& receives sensations from all the muscles \& organs of the body. Now the nerve to the eye is connected to a quite recent part of the brain, and is associated with the areas that seem to have nothing to do but are apparently responsible for abstract \& constructive thought, \& speculative. This is interesting. Obviously, I think, people like Wallace Stevens house their demon where the eye-nerve enters - so that everything is arbitrary \& colourful \& partial \& questionable. Whereas Wyatt \& Crowe-Ransome house theirs where the ear enters - so that in them everything is inevitable \& final \& bottomless \& unquestionable as the response of glands or the harmony of muscles... The former - the eye - only interprets things from the outside, in a 
domineering speculative way - the latter, the ear, expresses movements from inside... ${ }^{118}$

Hughes was drawn to the idea of the archetypes because they are not experienced rationally or intellectually, and because when they are experienced, like spoken poetry, they appear to us as unquestionable and final. Myth is opposed to rational thinking because the latter involves a mode of logic that separates and isolates objects from their environment (often reducing objects to their components) in order to understand them. Myths, like poetry, contain a species of logic that seeks to explain the object through its relationships to other objects through metaphor or metonymy. These connections may be experienced as paradoxical or mysterious like the connections between the psychological and material world. If we attempt to explain such paradoxes rationally, they seem illogical and absurd because our rational logic does not allow such connections. However, the appearance of an archetype in an artist's work signals an attempt to strengthen or restore such connections within the artist's psyche. Where the artist's personal psychological need reflects some crisis in the artist's culture, we recognise the solution as a great work of art because of the psychological cure it offers in its symbols and drama. In his critical writings, Hughes described this kind of cure being evident in Shakespeare's, Coleridge's, and Plath's writings. In their private 'myth', these artists all, in their work, attempted to cure some personal crisis and in doing so provided a cure that addressed a wider socio-political crisis within the artist's tribe. The notion of the poet as a healer brings us to Hughes's conception of the poet as a shaman.

Drawing on Mircea Eliade's Shamanism (1964), Hughes often compared the role of the poet to that of the shaman. He believed that the poet's role, like the shaman's was to re-connect his tribe with the psychic energy that would cure it. Like the Romantics before him, Hughes believed the psychic cure was to be found within nature and that human nature resided in the non-rational, non-civilised, aspects of experience. In his essay 'Regenerations' (1964) Hughes describes shamanism as “a technique for moving in

\footnotetext{
${ }^{118}$ Reid, Christopher. Letters of Ted Hughes. London: Faber, 2007. 96-7. Hereafter referred to as 'Letters of Ted Hughes'.
} 
a state of ecstasy among the various spiritual realms" at a time of personal or public crisis. He describes the role of the shaman as "to guide some soul to the underworld, or bring back a sick man's soul, or deliver sacrifices to the dead, or ask spirits the reason for an epidemic. ${ }^{119}$ In his writings on the imagination, Hughes often switched between anthropological and psychoanalytical registers and so we should consider his use of the terms 'spirits' 'demons' and 'psychic energy' as interchangeable. In discussing the role of the poet, Hughes sometimes described the shamanic journey in secular psychoanalytical terms, as the poet visiting the dark uncharted realm of the unconscious and returning with healing energies, as he explained in 1986:

True poetry...the stuff which mankind finally values, is a healing substance - the vital energy of it is a healing energy, as if it were produced, in a natural and spontaneous way, by the psychological component of the auto-immune system, the body's self-repair kit. ${ }^{120}$

In his understanding of true poetry as a healing force, Hughes used Keats's distinction between the poet and the dreamer. In the poems of the dreamer we would find a description of the malady not a solution or healing response to the crisis. A poet, on the other hand, at least a true poet, would provide the medicinal response to the malady:

[True poetry] has to draw its energies from quite a different source - not from a source generally distributed throughout prevailing circumstances, but from a source in the biological core of an individual. These energies, that Keats called 'balm', make the healing work out of themselves. We recognise [great works of art], eventually, because we find they do in fact heal us - or they make us feel as if we were being healed, we search them out like the sick animal searching out for the specific healing herb. ${ }^{121}$

\footnotetext{
${ }^{119}$ Hughes, Ted. 'Regenerations' (1964). Winter Pollen: Occasional Prose. London: Faber \& Faber, 1994. 56. Hereafter referred to as 'Winter Pollen'.

${ }^{120}$ Hughes, Ted. 'Keats on the Difference between the Dreamer and the Poet (1986). Winter Pollen: Occasional Prose. London: Faber \& Faber, 1994. 249. Hereafter referred to as 'Winter Pollen'.

121 'Winter Pollen'. 250.
} 
Hughes's notion of the true poet, as shaman, seeking out the psychic cure, is precisely the description he provides of Plath in Birthday Letters as she leans over her desk and searches for the inspiration for her Ariel poems:

Like an animal, smelling the wild air,

Listening to its own ailment

Then finding the exact herb.

It did not take you long

To divine in the elm, following your pen,

The words that would open it.

In seeking to heal a private hurt, the visionary poet finds the balm for a particular social problem in the psyche of his tribe or nation. As we have seen, Hughes identified the psychological crisis of the modern age, at least in the West, as related to our privileging of rational objective experience over our subjective inner lives. The modern poet's role, then, for Hughes, is to restore this link to the inner world.

As a late Romantic, Hughes believed the psychological crisis in the West was linked to the problem of civilisation and that linking humanity back with its primitive nature, and with nature itself was the true purpose of poetry. These ideas were drawn, in no small part, from his reading of Robert Graves's book, The White Goddess, which he described as the "the chief holy book of my poetic consciousness". ${ }^{122}$ Hughes received The White Goddess as a gift from his favourite grammar school teacher, John Fisher, in 1951, when he matriculated at Cambridge. He was re-reading this book with his Cambridge friends when he met Sylvia Plath. ${ }^{123}$

In The White Goddess, Graves argues that the original function of the poet was to write hymns for the Moon Goddess, the original muse and the mother goddess of the original matriarchal societies in Northern Europe and in the Mediterranean. The White

122 'Letters of Ted Hughes'. 96. [Letter to Robert Graves. 20 July 1967]

123 'Her Husband'. 31. 
Goddess is an embodiment of the Jungian mother archetype, the mother of life and death. Graves describes her as a creative and destructive force, associated with nature and symbolised by the moon in her three aspects (waxing, full, and waning). The White Goddess was originally represented in triptych as a maiden, woman, and old-hag, and was associated with the colours red, white, and black. In a 1995 letter to Nick Gammage, Hughes described the profound effect The White Goddess had on his notion of poetry:

I first met The White Goddess in September 1951... and I recall my slight resentment to find [Graves] taking possession of what I considered to be my secret patch. I was familiar with all but the more arcane bits of the mythology had known the Middle Eastern and Egyptian material since I was fifteen, plus the Mabinogion and the Irish. I regarded all that as my speciality. And in particular, I suppose, what really interested me were those supernatural women... once I got used to Graves, and realised he shared some of my obsessions, I suppose I more or less soaked the book up. It was there all through my three university years, to hand. Eventually I imagine it had a big effect on me (and on SP when I got her into it, later on). I suppose through Graves I began to see the whole thing had its roots in biology - rather than in the related fantasies of different or related nations. I began to see it more as a language in itself. Also, by chance I had started to read Jung before I did my National Service. My sister (my pathfinder) had bought Psychological Types and that was one book I knew backwards - the theory of it - by the time I went to University. So I read Graves through Jung. I began reading myths and folklore when I was thirteen or fourteen, and for years, apart from poetry, that was pretty well all I read. ${ }^{124}$

Graves argued that the original and true function of poetry was to compose hymns for the great mother who was worshipped in European matriarchal tribes from the "Old Stone Age". The White Goddess presided over all acts of generation - physical, spiritual and intellectual - and was nature herself. According to Graves, poetry was originally

124 'Letters of Ted Hughes'. 679. 
concerned only with a single myth, which he calls "The Theme", which is a mythic drama written in celebration of the White Goddess, and which he summarises as follows:

The Theme, briefly, is the antique story... of the birth, life, death and resurrection of the God of the Waxing Year: the central chapters concern the God's losing battle with the God of the Waning Year for love of the capricious and all powerful Threefold Goddess, their mother, bride and layer-out. The poet identifies himself with the God of the Waxing Year and his Muse with the Goddess; the rival is his blood-brother, his other self, his weird. ${ }^{125}$

According to Graves, "all true poetry celebrates some incident or scene in this very ancient story", and he argues that "the three main characters [the Goddess, the God of the Waxing Year, and the God of the Waning year] are so much a part of our racial inheritance that they not only assert themselves in poetry but recur on occasions of emotional stress in the form of dreams, paranoiac visions and delusions." ${ }^{\prime 26}$ In writing poetry around "The Theme", the true poet identifies himself with the sacred king, the god of the waxing year and as lover of the Goddess. His rival is the God of the Waning Year, who will eventually be resurrected and take his place beside the Goddess. Graves points out that myths all over the world (for example, the Egyptian myth of Horus, Isis, and Osiris) record scenes from the Theme.

As James Frazer shows in The Golden Bough, the story that Graves calls "The Theme" was represented in the ritual slaying of the sacred king (or the tribe's scapegoat) who ruled as the goddess's lover for half a year until he was, in turn, killed and replaced by his tanist, the god of the waning year. The tanist then takes the sacred king's place as the goddess's lover for the remainder of the year until, at Winter Solstice, he is killed and replaced by the resurrected sacred king, and so on. The two kings are sometimes described as twins or as father and son, and the health of the tribe is dependent on the king's death and resurrection, a necessary ritual to appease the Goddess and ensure the

\footnotetext{
${ }^{125}$ Graves, Robert. The White Goddess: A Historical Grammar of Poetic Myth. New York: Farrar, Straus and Giroux, 2001 [1948]. 24. Hereafter referred to as 'The White Goddess'.

126 'The White Goddess'. 24.
} 
continuing cycle of death and rebirth. For Graves, the function of true poetry remains the same for the poets of modern industrial societies: it is a celebration of the sacredness of life and the connection of man and divine nature - the Goddess. Indeed the 'Theme' now offers an urgent warning about humanity's neglect and betrayal of the Goddess:

The function of poetry is religious invocation of the Muse; its use is the experience of mixed exaltation and horror that her presence excites... This was once a warning to man that he must keep in harmony with the family of creatures among which he was born, by obedience to the wishes of the lady of the house; it is now a reminder that he has disregarded the warning, turned the house upside down by capricious experiments in philosophy, science and industry, and brought ruin on himself and his family. ${ }^{127}$

According to Graves, from the Bronze Age onwards "poetry becomes academic and decays until the Muse chooses to reassert herself in what are called the Romantic Revivals." ${ }^{\prime 28}$ Only true poetry serves the ritual purpose of healing this severed connection and this remains its function, an opinion Hughes reiterates in a 1995 letter to Nick Gammage:

The overall pattern of Goddess-centred matriarchy being overthrown by a Godcentred patriarchy was most likely something I first grasped from Graves ...I did eventually - and quite quickly - come to regard all post-Restoration English psychic life as something cut off from its true source and grafted onto other supply lines, alien ones. Except for the generation of Blake, Wordsworth, Coleridge, Keats. ${ }^{129}$

From Hughes's earliest poems we encounter an image of humanity estranged from his inner world and nature, reiterating Romanticism's complaint about the individual's failure to recognise itself as a part of a larger machinery of meaning. The

\footnotetext{
127 'The White Goddess'. 14.

128 'The White Goddess'. 393.

129 'Letters of Ted Hughes'. 680.
} 
animals in his poems are, in stark contrast to man, unfettered by intellectual ideals and instinctually rooted in their environment. In the poems we encounter the Goddess as nature in her original pagan image, as the goddess of birth and death - both beautiful and terrifying, and his poems are remarkable in their ability to deliver an unflinchingly unsentimental examination of the (often violent) energies and mechanisms of nature that manifest themselves innately in the behaviour of animals. In the title poem of Hughes's first collection, The Hawk in the Rain (1957), the speaker struggles to cross a wet ploughed field in a heavy downpour while the hawk hangs effortlessly: "His wings hold all creation in a weightless quiet" (THC.19). ${ }^{130}$ In this encounter with the hawk, the speaker's delusion of independence from his environment is shattered, and he learns that it is the hawk, and not he, who is in control of his world. Similarly, in the collection's second poem, the smouldering rage of 'The Jaguar', removed from its true environment and imprisoned in a manufactured cage, offers a dramatic symbol of the sickening inner world - its energies, denied access to life, become a relentless torture. In a later poem in the same collection, 'Wind', the battering force of the wind against the house can be seen as a representation of the primitive elemental forces of nature that threaten the fragile structure of the ego. In 'Wind' as in 'The Jaguar', nature does not recognise the civilised limits imposed upon it.

In Hughes's second book, Lupercal (1960), the hawk that is the speaker of 'Hawk Roosting' advises that it suffers "no falsifying dream" (THC.68) but is perfectly attuned to its inner and outer needs. Unlike man, the hawk is not estranged from its authentic self by abstract thought and reason ("there is no sophistry in my body... no arguments assert my right" (THC.69)) as it knows instinctively its place within creation's cycle of death and rebirth. In another Lupercal poem, 'Thrushes', Hughes celebrates the instinctive vitality of the birds, which both frightens and fascinates the human observer:

No indolent procrastinations and no yawning stares.

No sighs or head-scratchings. Nothing but bounce, and stab

\footnotetext{
${ }^{130}$ Hughes, Ted. Collected Poems. London: Faber and Faber. 2003. 19. Hereafter referred to in parentheses in the text: e.g. (THC.19).
} 
And a ravening second.

In watching the birds, Hughes suggests that the 'terrified' observer becomes aware of his estrangement from his own instinctual needs and his authentic self. The thrushes are part of the huge machinery of nature that man stands outside, clinging to his objective ideals. In 'To Paint a Water Lily' Hughes provides a symbol of the single natural organism living in two worlds, as though a symbol of the inner and outer lives that make up the conscious individual. On the surface of the pond the lily appears to be: "still / As a painting, trembling hardly at all... Whatever horror nudge[s] her root" (THC.71). In "An Otter', Hughes describes another organism existing in two worlds simultaneously. The otter is "neither fish nor beast" and "Of neither water nor land" (THC.79). Hughes would have known, from Eliade's Shamanism, that because the otter lived in two worlds it was connected with the shaman in some primitive cultures. Like Hughes, the otter of his poem is "Seeking some world lost when first he dived, that he cannot come at since" (THC.79).

While Hughes's early observational poems used the formal properties of rhyme and metre to fetter the uncivilised powers they unleashed, by 1971, when CROW: From the Life and Songs of the Crow appeared, Hughes had begun to control these unmannerly energies with mythical structures. Crow owes its genesis to the mythical trickster cycle in Native American folklore, particularly those of the Haida and the Tlingit on the Northwest coast. ${ }^{131}$ Following the pattern of these original myths, Crow is born, witnesses creation, and wanders the world trying to come to terms with his nature, his appetites, and his environment, as Hughes explained: "The Crow is another word of course for the entrails, lungs, heart, etc - everything extracted from a beast when it is gutted. The Crow of a man, in other words, is the essential man - only minus his human looking vehicle, his bones and muscles."132 Unlike Hughes's earlier animals, Crow embodies many human traits and often appears to be an image of humanity's instinctual potentiality stripped of its ego-centered personality. In other misadventures Crow is confounded by

\footnotetext{
${ }^{131}$ Hirschberg, Stuart. Myth in the Poetry of Ted Hughes. Totowa, New Jersey: Barnes and Noble Books, 1981. 69. Hereafter referred to as 'Myth in the Poetry of Ted Hughes'.

${ }^{132}$ Ted Hughes quoted in: 'Her Husband'. 230.
} 
the strange idea of 'civilisation'. Crow is not fettered by social manners or by abstract thinking and so we are able to see him facing and coming to terms with his inner desires during his wanderings. In 'Crow Tyrannosaurus', Hughes links Crow to one of the most ferocious meat-eating dinosaurs in a mythopoeic fable that provides a warning about the nature of objective rational thought. In this poem, Crow witnesses the cruel nature of life and death in a "cortège of mourning and lament" (THC.214) as a line of animals pass by, sustained by the deaths they have caused. The swift's body is "Pulsating / With insects / And their anguish, all it had eaten"; the cat is: "A tunnel / Of incoming death-struggles, sorrow on sorrow"; and the dog is "a bulging filterbag / Of all the deaths it had gulped for the flesh and the bones" (THC.214-5). Although man is, like the other animals, sustained through killing, Crow notices that his abstract mind disconnects him from nature so that he kills abstractly, and justifies death and suffering through ideology. To Crow, man appears to be a factory built for systematic murder, his body is an "Abattoir / Of innocents - / his brain incinerating their outcry" (THC.215), a description that links this aspect of humanity to the Holocaust.

In 'Crow's Account of St George', Hughes presents a parody of the knight's mythical quest that features a modern hero - a scientist reducing the world to the sum of its parts:

He sees everything in the Universe

Is a track of numbers racing towards an answer.

With delirious joy, with nimble balance

He rides those racing tracks. He makes a silence.

He refrigerates an emptiness,

Decreates all to outer space,

Then unpicks numbers. The great stones fall open.

With the faintest breath

He melts cephalopods and sorts raw numbers

Out of their dregs. With tweezers of number

He picks the gluey heart out of an inaudibly speaking cell...

(THC.225) 
In this poem, the hero then hears something that startles him, and finds himself surrounded by demons which, in comic-strip style, he promptly batters to death, cutting them to "segments" with his sword. The poem ends when our hero recovers from his momentary delirium and "Drops the sword and runs dumb-faced from the house / Where his wife and children lie in their blood" (THC.226). Like Heracles, our hero has killed his wife and children in his madness, by reducing them, rationally, to "segments". Here then, Hughes combines two myths, that of St. George and the Dragon and that of Heracles's madness, in order to portray the "madness" of a purely objective view of the world that denies one's inner world and subjective experience.

'Crow and Mama' is another poem that issues a warning about humanity's estrangement from nature by depicting Crow's futile attempts to live independently of, and deny his dependency on, his mother:

When Crow cried his mother's ear

Scorched to a stump.

When he laughed she wept

Blood her breasts her palms her brow all wept blood.

He tried a step, then a step, and again a step -

Every one scarred her face for ever.

When he burst out in rage

She fell back with an awful gash and a fearful cry.

When he stopped she closed on him like a book

On a bookmark, he had to get going.

(THC.219) 
Wanting more independence, to control his own fate, Crow attempts to separate from his mother. However, he finds that whatever plan, feat, or technology he devises to escape, he remains helplessly dependent on her, perpetually trapped within her shadow:

He jumped into the car the towrope

Was around her neck he jumped out.

He jumped into the plane but her body was jammed in the jet -

There was a great row, the flight was cancelled.

He jumped into the rocket and its trajectory

Drilled clean through her heart he kept on

And it was cosy in the rocket, he could not see much

But he peered out through the portholes at Creation

And saw the stars millions of miles away

And saw the future and the universe

Opening and opening

And kept on and slept and at last

Crashed on the moon awoke and crawled out

Under his mother's buttocks.

(THC. 219-20)

Throughout Hughes's poetry, we encounter this repeated warning about humanity's estrangement from its own true nature by a narrow mode of perception. These preoccupations also pervade his critical writings. Hughes argued that the "creative imagination, like evolutionary biology, has a kind of unscrupulous economy about its 
emergency adaptations" 133 and so in his interpretations of other poets he attempts to identify the archetypal drama beneath the surface. In his essay on Coleridge, 'The Snake and the Oak' (1996), he argued that 'Kubla Khan', 'The Rime of the Ancient Mariner', and 'Christabel' Part 1, were Coleridge's three 'visionary poems' which 'together make a single myth, which is also, as a poet's chosen myths always are, a projected symbolic self-portrait of the poet's own deepest psychological make-up." "134 Because Coleridge's myth is a symbolic drama that preoccupies and controls the poet's imagination, it contains his fate:

Once Coleridge's main symbols have been identified, and their place and function in his double nature grasped, everything unfolds like the plot of a play, with the various characters (the symbols and symbolic figures) coming and going, interacting, changing, revealing more of their true nature, as they work out Coleridge's fate. ${ }^{135}$

According to Hughes, Coleridge's three visionary poems can be understood as a record of his 'shamanic flight' into the collective unconscious, the source of the symbols and drama in many folktales and myths, to recover the psychic healing balm for a personal psychological crisis. In 'The Ancient Mariner', Coleridge's symbol of the albatross as the mariner's animal helper, is, for Hughes, a symbol that is biological inevitable: "Countless folktales follow the same shamanic route that the Mariner follows here. In a great many of them, the animal on the threshold is a standard dramatis persona - as if an animal symbol on the side of the ovum should confront the sperm."136 Having confronted the Goddess, the Mariner returns from his shamanic flight with a healing vision that he is then compelled to share with his audience. In 'Christabel' and 'Kubla Khan', Coleridge must again confront the goddess (Geraldine and the 'damsel with a dulcimer'), a pagan image of nature as both creative and destructive, in all its beauty and horror, an image of truth that was crucially missing from his Christianity:

\footnotetext{
133 'A Choice of Coleridge's Verse'. 27.

134 'A Choice of Coleridge's Verse'. 4.

135 'A Choice of Coleridge's Verse'. 5.

136 'A Choice of Coleridge's Verse'. 54.
} 
The same archetypal world that has revealed itself, in some not too dissimilar form, in all cultures, as one of the earliest, most profound, most intimately meaningful and all-embracing 'religious' truths. It is the world of the great Female of Life and Death, in whom the sexually irresistible 'bride' somehow embodies not only the animal and vegetable kingdoms, and the processes of the elements, but the extremes of the devouring grave and the maternal womb. These last two in particular, like her two selves fighting for dominance, do not so much alternate as coexist, each within the other. ${ }^{137}$

Hughes argues that although Coleridge's visionary poems were inspired by a personal crisis relating to his Christian faith, which seemed to exclude some vital part of his inner self, his pagan vision offered an image of the completeness to a wider religious crisis being played out in England from the Reformation. It is the healing energy in these visionary poems that makes us recognise their greatness. Nevertheless, Hughes argues that Coleridge fled from the implications of his poems into the safety of intellectual rationalism, where he could avoid the powerful emotions his vision aroused within the “Christian self” he identified with. In refusing the Goddess's "call”, Hughes argues, the shaman would traditionally expect a death of some kind, and for Coleridge this was the death of his poetic life; he never wrote another visionary poem.

In his book Shakespeare and the Goddess of Complete Being, Hughes provides a similar description of Shakespeare's mythopoeic imagination. Hughes argues that Shakespeare's entire oeuvre is framed upon the myth of the goddess and her consort, or fragments of this myth, which Shakespeare first explored in his long poem Venus and Adonis. According to Hughes, Shakespeare found the dramatic material for his plays in this myth and its motifs of sacrificial death and rebirth became the dramatic "Equation" that lies behind the drama and characters in the various plays:

137 'A Choice of Coleridge's Verse'. 83. 
This is the point I shall try to establish. By constructing his basic Equation out of living myth, [Shakespeare] is able to create dramas which, no matter how secular they seem, or how real in the dimension of external historic event and of psychology, nevertheless embody and communicate a very particular 'mythic' dimension, which is to say a 'divine' or 'daemonic' dimension... His mythic Equation operates...in each work, as a controlling, patterned field of force, open internally to the 'divine', the 'daemonic', 'the supernatural' (of which the constituent myths were the original symbolic expression), but externally to the profane, physical form and individualities of the action, to the words of the actors. An example of what I mean, to anticipate a little, appears in his use of the myth of Venus and Adonis. Basically, this is the most familiar variant of the myth of the Great Goddess and her consort, the sacrificed god, the myth of one of the most widespread and profoundly rooted religions of the archaic world. Shakespeare appropriates it by adapting it to his particular needs... ${ }^{138}$

According to Hughes, Shakespeare used the myth of Venus and Adonis to drive his plays towards a resolution of death (tragedy) or rebirth (redemption). In Hamlet and Macbeth the drama concludes with Adonis's death and tragedy. However, in other plays, such as The Tempest, the drama leads to a conclusion of liberation and rebirth. Hughes's reading of The Tempest is particularly interesting in that it helps explain his reading of Plath's life and writings in Birthday Letters. Hughes reads Ariel's escape from the pine in Shakespeare's play as a reassertion of the mythic story of Adonis's birth from a myrrh tree, as he explains in Shakespeare and the Goddess:

According to the Cyprian version, [Aphrodite] compelled the virgin Smyrna to seduce her drunken father. Learning that he had sired her unborn child, he chased his daughter to kill her. As the sword descended, Aphrodite transformed the girl into a myrrh tree. The blade split the trunk and out tumbled baby Adonis, the Divine Child, the god of the earth's flowering. This overture to the myth is the

\footnotetext{
${ }^{138}$ Hughes, Ted. Shakespeare and the Goddess of Complete Being. London: Faber, 1992. 3. Hereafter referred to as 'Shakespeare and the Goddess'.
} 
vestige of a grander event, more fully dramatized in other variants, where the god is released or reborn from the tree, as if by Caesarean birth. ${ }^{139}$

The peculiar origin and fate (being born from a tree and turned into a flower by Aphrodite) of the young Adonis places him "in the lineage descending to Ariel, whom Prospero released from the pine and who thereafter lived in a cowslip." ${ }^{140}$ In Birthday Letters, the baby Adonis and the spirit Ariel are shown to be in a direct lineage to the Ariel-voice that is released in Plath's 'Elm'. As we will see in chapter 5, Hughes interprets Plath's poems as being the mythopoeic record of the birth of her own creative and true self, which had been buried with her dead father and neglected. ${ }^{141}$ In his analysis of Plath's writings, like those of Coleridge and Shakespeare, he identifies the mythic drama as a backdrop over the temporal events in the foreground where the characters must perform their assigned mythic roles.

Hughes's mythic reading of Plath's poems frames his mythopoeic response in Birthday Letters. Despite the general reluctance of readers to look beyond the autobiographical details of Birthday Letters, several critics have noted a mythic structure in Hughes's sequence. As I said in the previous chapter, Stallworthy and Bundtzen have suggested that the poems use a mythic structuring principle. In Stallworthy's reading, the myth of Echo and Narcissus lies behind the story in the Birthday Letters poems.

Stallworthy suggests that Plath plays the role of Narcissus, finding her 'self' reflected in everything she looks at, and Hughes is Echo, forced to echo her utterances in order to mourn her. Bundtzen, on the other hand, points out the strong correspondences between Hughes's sequence and the myth of Orpheus and Eurydice. Bundtzen identifies Hughes with Orpheus (the first poet and son of the Muse Calliope), and Plath with Eurydice. Bundtzen points out that Eurydice was killed when she was bitten on the foot by a snake while being pursued by the amorous bee-keeper Aristaeus (Otto Plath). In 'A Picture of Otto', Hughes, as Orpheus, journeys into the underworld to ask Otto Plath for his

\footnotetext{
139 'Shakespeare and the Goddess'. 6.

140 'Shakespeare and the Goddess'. 6-7.

${ }^{141}$ In The White Goddess, Graves advises that elm trees were traditionally believed to place a tap root into the mouths of the dead in graveyards. Plath's poem takes up this belief to commune with her dead father.
} 
daughter. However, he is unsuccessful in his quest to recover Plath from her father, because she has always conflated Otto and Hughes (as in the poem 'Daddy') and so he cannot engage with her outside the double-vision of her poetic terms.

Bundtzen is right to compare Birthday Letters to the myth of Orpheus and Eurydice, for this is a variant of the Goddess myth, of the sacred king's death, and his journey into the underworld to unite with the Goddess in death before his eventual rebirth. Hughes follows Graves's insistent requirement that the true poet should identify with the 'Star Son', the 'God of the Waxing Year' who is killed to guarantee the Goddess's magical rebirth. His twin and rival for the Goddess' affections, the God of the Waning Year, is Otto Plath, with whom Hughes must contend for possession of Plath. This much is evident in Hughes's interpretation of Plath's mythic drama and in his interpretation of her writings. However, Birthday Letters also tells Hughes's own story, and to understand this we stay with Orpheus a little longer. According to Ovid, following his loss of Eurydice, Orpheus foreswore the love of women (another betrayal of the Goddess) and was torn apart by the Maenads. Orpheus's dismembered head, still singing, floated down the Hebron River into the Mediterranean, where it was carried to the island of Lesbos. Here it was finally buried and Orpheus was united, in death, with his beloved Eurydice. The Maenads' dismemberment of Orpheus offers a metaphor for Hughes's treatment by Plath's feminist readers and biographers following her death. He believed that this spiritual dismemberment was a necessary stage of the shaman's preparation before he could enter the spiritual realm of the dead and obtain the necessary healing energies. As he explained in his essay 'Regenerations':

The transformation ... is a magical death, then dismemberment, by a demon or equivalent powers, with all possible variants of boiling, devouring, burning, stripping to the bones. From this nadir the shaman is resurrected with new insides, a new body created for him by the spirits. ${ }^{142}$

\footnotetext{
142 'Winter Pollen'. 57.
} 
This spiritual dismemberment (or in psychological terms the destruction of the ego by the unconscious) is what Coleridge was afraid to face in his visionary poems and fled from into his Christian intellectualism. It is that terrifying aspect of self that Plath recognised in her own visionary poems but that she nevertheless faced in order to achieve her triumphant rebirth in Ariel. As we will see in the following chapters, in Birthday Letters, Hughes uses the myth of the dismembered Orpheus mourning his dead lover and finally reuniting with her in death, as a means to imaginatively heal himself and recover Plath from the antagonistic terms of her own myth and from the discourses that repossessed her. Birthday Letters is a way for Hughes to recover his private feelings and impressions of Plath and frame these in an archaic mythic form that resists contamination by others. In the penultimate Birthday Letters poem, 'The Dogs Are Eating Your Mother', Hughes describes the consumption of Plath by her readers as the necessary dismemberment that enables her resurrection and rebirth in the last Birthday Letters poem, 'Red' which leads the entire sequence to a final, private, life-affirming image of her. As we will see in chapter 7 ('The Shamanic Journey'), this is the final healing act of imaginative rebirth that Birthday Letters attempts. 


\section{Subjectivity}

\section{Subjectivity}

Hughes believed that because all our perceptions of the objective world are mediated by our inner world, our experiences of reality are necessarily subjective. Nevertheless, being of an intensely private nature, he was reluctant to expose himself in his writings, and so we rarely encounter a discernable historically specific personality in his poetry prior to Birthday Letters. He also believed that poetry should not be limited by the confines of the poet's conscious personality; as Middlebrook has pointed out, he conceived of poetry as "a force for uncivilising the reader" and believed that "literature works by penetrating consciousness at a level not reached by the speech of everyday transactions." "143 Hughes's interests in the natural world, his esoteric study of alchemy, astrology, magic, anthropology and myth provided the symbolism with which he could explore personal preoccupations in his poems without exposing their introspective origins. Consequently, when Birthday Letters appeared, as Erica Wagner puts it, "it burst into the world without warning... it was a book no one ever expected to see." And "Hughes was the last person anyone would have expected to produce such a book." "144 What was immediately striking about the poems was not just Hughes's openness about his relationship with Plath, but that he had chosen to address her directly through a firstperson narrative. ${ }^{145}$ Hughes's decision to offer such a raw and unguarded narrative seems to have been prompted by the powerful subjectivity in Plath's writings and the subjectivity and mythopoeia of Birthday Letters was part of Hughes's response and tribute to her writings.

Kroll has pointed out that in Plath's late poems objective reality is filtered through the hallucinatory lens of the author's subjective experience: "there is no encounter with objective reality distinctly different from the speaker's inner reality; no case of an objective reality becoming, in the course of the poem, coloured and transformed by an emotional condition." "146 In 'Poppies in October', for example, the poppies are not just

\footnotetext{
143 'Her Husband'. 229.

144 'Ariel's Gift'. 2.

145 However, in 'The Pan' and 'The Inscription', Hughes describes himself in third-person.

146 'Chapters in a Mythology'. 15.
} 


\section{Subjectivity}

"like" mouths, they are mouths and the red flowers are "blood clots". Plath does not bring attention to herself in the act of making poetry. The subjective details are urged upon the reader as though they are the direct content of her experience and create the impression that her direct experience is metaphorical. ${ }^{147}$ In Birthday Letters, Hughes accepts the hallucinatory subjectivity of Plath's dramatic mythopoeia as a reality that he must reside in and engage with. Throughout the narrative he describes how he is reluctantly drawn into Plath's mythos - the story that is filtered through her imaginative vision. Nevertheless, his first-person narrative allows him to foreground the subjectivity of his own vision, understanding and conclusions about particular events. Hughes sets out his experiences as he experienced or understood them at the time, and how he later understood them retrospectively. In setting his subjectivity against Plath's in Birthday Letters, he accepts the partial relativity of either vision as both focus on different aspects of the same events in their different accounts.

The assumption of several critics ${ }^{148}$ that Hughes privileged his own interpretation of shared experiences over Plath's in Birthday Letters is the result of a preconceived view that Hughes is attempting to justify his actions in the poems. However, the internal poetic evidence does not support this charge. More often than not in Birthday Letters, Hughes's poems adopt the subjective conditions imposed on reality in Plath's poems, and when he disagrees with Plath's perspective, he does so only to retrospectively defer to Plath's more insightful vision. In 'The Fifty-Ninth Bear', for example, which relates to an incident that occurred when Hughes and Plath camped in Yellowstone Park during a 1959 drive across America, they are awoken in their tent at night by the sound of a bear breaking into their car. Hughes recalls that he considered confronting the bear and scaring it away from their provisions:

A few shock-shouts,

\footnotetext{
147 'Chapters in a Mythology'. 16.

${ }^{148}$ Such as: Pollitt, Katha. "Peering Into the Bell Jar'. The New York Times. 1 March 1998. / Scigaj, Leonard. 'The Deterministic Ghost in the Machine of Birthday Letters'. In: Moulin, J. Ted Hughes: Alternative Horizons. Taylor and Francis Group. London. 2004. / Jackson, Anna. 'Sylvia Plath's "Exaggerated American Grin": Anti-American Sentiment and the Reception of Plath's Poetry'. Journal of Transatlantic Studies, 5(2) 2007, 117-132.
} 


\section{Subjectivity}

I thought, a close-up assault of human abuse,

And the bear would be off. I'd take my hatchet

Just in case. I got out my hatchet,

Pitifully unimaginative.

I was remembering those amiable bears.

That's how it happens.

Hughes recalls that having seen fifty-eight "amiable bears" already that day, he had become used to seeing them wandering around the park "Romping like big rubber toys, / Bouncing along, like jolly inflatables" (BL.91) as though the bears were simply there for the tourists' cameras, as part of the park's entertainment. Plath sees the situation differently; she is frightened by how the bear may react if confronted and persuades Hughes to remain in the tent while the bear breaks into their car. ${ }^{149}$ On the following morning, Plath returns from the camp "wash house", having learned that another camper was killed by a bear that night in very similar circumstances. Hughes suggests that his "doppelganger", this other camper apparently believed, like Hughes, that he could chase the bear away, had "learned - / Briefly, in what flash of reckoning / He'd been allowed" (BL. 94) that "A bear's talons... by human flesh / Can be considered steel, braced on tendons / Of steel hawser...on the end of an arm / That can weigh sixty, seventy, eighty pounds / Moving at 90m.p.h” (BL.94). Plath believes that Hughes's 'double' had been killed by "that very same bear" and she conjectures that "Having murdered a man, [the same bear had] romped through the woods / to rob us" (BL.94). Looking back on the events, Hughes acknowledges that Plath's “terrors were / More intelligent, with their vision", while his own reckoning had been "pitifully unimaginative" (BL.92).

In 'The 59th Bear', Hughes is also making sense of the way that Plath used events in her everyday life for poems. He recalls that she later used this "dud scenario" (BL.94) for her short story 'The Fifty Ninth Bear' in which the speaker's husband leaves the tent to try and shoo away the bear and is killed. Jacqueline Rose has pointed out that Plath's story does not rely on the reader's knowledge of the biographical event behind the poem,

${ }^{149}$ The car belonged to Sylvia's mother, Aurelia Plath, and had been lent to them for the road trip. 


\section{Subjectivity}

and can be read as a critique of the commercialisation of nature, the transformation of wilderness into theme parks. Hughes revisits this theme in his responding poem.

However, because many of Plath's readers approach her work through her biography, 'The Fifty-Ninth Bear' has been read as a confessional fantasy by Plath about Hughes's death. At first glance, it would seem odd that Hughes should revisit the biographical situation behind Plath's short-story and, in this way, encourage a confessional interpretation of her short-story. However, in returning to these particulars Hughes illustrates the gap between the event and the description of the event in Plath's art. In this way Hughes bolsters his notion that Plath consistently saw everyday events through the dramatic terms of the myth of the Goddess and her dying consort, a theme that would finally emerge in her Ariel poems. Retrospectively, Hughes uses this example to point out that both Plath and the bear share an instinct in the brain that, once triggered, instantly "turns life to paper" (BL.94). The bear dismembers with his physical violence and Plath does so by squeezing "the possible blood out of [the event] / through [her] typewriter" (BL.94). Thus, in 'The 59th Bear', Hughes retrospectively interprets Plath's short-story as an omen of the 'psychological drama' of Ariel struggling to make itself known to her creative consciousness:

\section{At that time}

I had not understood

How the death hurtling to and fro

Inside your head, had to alight somewhere

And again somewhere, and had to be kept moving,

And had to be rested

Temporarily somewhere.

When, Hughes's and Plath's accounts contend for the truth of an event, as in 'The $59^{\text {th }}$ Bear', the discrepancies between the accounts can unsettle the reader's confidence in knowing not only the 'truth' of what actually happened (the logos) but also what these events actually signify (the mythos). In confronting Hughes's subjectivity, readers are forced to face Plath's subjectivity and her tendency to blend fact and fiction. Throughout 


\section{Subjectivity}

Birthday Letters, Hughes demonstrates how easy it is present events so as to prompt a particular interpretation (or reading) of events.

In her essay 'Dangerous Confessions', Tracy Brain analyses some of the problems associated with 'biographical' interpretations of Hughes's and Plath's writings. One of her most interesting readings revolves around the event that led to Plath's short story 'The Fifty Ninth Bear'. Brain highlights the discrepancies through a comparison of various accounts of what actually happened, and the tendency to confuse fact and fiction, even when the sources of information are Hughes and Plath themselves. The earliest record of this incident is Plath's own account in a letter to her mother. We take up the account on the morning after the bear's visit:

I mentioned the incident to a woman up early in the lavatory... she had just been moved from West Thumb, another camp, where a woman had been killed by a bear Sunday, the night we came. That woman, hearing the bear at her food at night, had gone out with a flashlight to shoo it away, and it turned on her and downed her with one vicious cuff... Well, this story put proper concern into us, too. By twilight we had the car kerosened, flung red pepper everywhere, sprayed Fly-Ded all about, drank Ovaltine and took a tranquiliser each. ${ }^{150}$

In Plath's account to her mother, the bear killed a female camper. However, in her short story as in Hughes's poem, the victim is a man. Biographers Anne Stevenson and Paul Alexander add further discrepancies. Stevenson does not acknowledge the sources for her account in Bitter Fame but, because she reports that the victim is male, she may have based her account on Plath's short story, or on a recollection of Hughes's. Stevenson also contradicts Plath's account to her mother in suggesting that Plath had become so upset by the incident that they had packed up and left the camp that morning ("We've got to get out of here!" cried Sylvia. "The bears are killing people!"151) In Hughes's poem 'The $59^{\text {th }}$ Bear', as in Stevenson's biography, Plath can be seen as over-

${ }^{150}$ Plath, Sylvia. Letters Home. London: Faber \& Faber, 1976. 350. Hereafter referred to as 'Letters Home'.

151 'Bitter Fame'. 160. 


\section{Subjectivity}

reacting to the situation by insisting that they leave the camp that same morning.

However in Plath's account to her mother, both Plath and Hughes are fortified enough to stay the following evening by taking "a tranquiliser each" and by scattering kerosene and red pepper around their camping area. Paul Alexander also provides no source for his account in Rough Magic. However, in stating that the camper killed was female, and in suggesting that Plath and Hughes stayed at the camp on the following evening, he is probably relying on the version of the story contained within Plath's letter to her mother. ${ }^{152}$ Whether this is the case, or not, we have no way of knowing which account is the more accurate. Although we might initially believe Plath's account to her mother rather than the accounts she and Hughes later fictionalised, as Brain points out, Plath may be over-dramatising the incident for later use in her writing (she often kept carbon copies and could always request her letters back from her mother). On the other hand, Plath may be exaggerating for effect or omitting, or altering facts, in her brief account to her mother that she later restores in her short story. She may also have remembered facts incorrectly - although these defects could, of course, be a feature of any of the previously discussed accounts.

Brain further unsettles the veracity of these accounts by pointing out that all of four indicate that neither Hughes nor Plath actually witnessed the death of the camper. They all state that Plath had learned the story from another camper and, as it happens, Brain has established that there were no human fatalities from any bear attack in Yellowstone Park during 1959. In fact, only five fatalities occurred between 1907 and 1986 and none within 10 years of Hughes's and Plath's visit [1907, 1916, 1942, 1972, and 1983]. ${ }^{153}$ Even with this information, we cannot be sure whether Plath or Hughes really believed that a camper had died or wilfully used the 'story' to create the impression that she and Hughes were having adventures in their travels, as Brain explains:

\footnotetext{
152 Alexander, Paul. Rough Magic. Cambridge MA: Da Capo Press. 2003. [1991]. Hereafter referred to as 'Rough Magic'. In many sections Rough Magic, the biography actually reads as though it has been ghost written by Aurelia Plath - for example, in cataloguing Aurelia's hardships and sacrifices and in countering Sylvia's critical comments about her mother.

${ }^{153}$ Brain, Tracey 'Dangerous confessions: the problem of reading Sylvia Plath biographically'. In: Gill, Jo. Modern Confessional Writing. New York: Routledge, 2006. 19. Hereafter referred to as 'Modern

Confessional Writing'.
} 


\section{Subjectivity}

It is possible that Plath genuinely believed that someone died the night the bear rummaged through their car. It is also possible that Plath knew no one had actually died, and she made up the fatality in order to show her mother what an exciting time she and Hughes were having, just as she made up the husband's death in 'The Fifty Ninth Bear'. The fact that she doesn't state when the fatal attack actually occurred might suggest that Plath realised the death was a sort of wilderness legend based on incidents that had happened. Plath does actually use the word 'story' in her letter to her mother: 'this story put proper concern into us'. Whether she does so to signal that the bear fatality might not have really taken place and might be an invented incident, or to mean a true account of what actually happened, we will never know. Whatever the case, biographers are united in their assumption that 'The Fifty Ninth Bear' is a confessional story based on real events. ${ }^{154}$

If we cannot trust Hughes's and Plath's accounts, and if Plath's biographers cannot be trusted to check the most basic facts, or to agree how the historical characters reacted to the event (did they leave the camp immediately or stay there the following night?), how can we ever establish what actually happened? This insight into the uncertainty of subjective autobiography seems to characterise Hughes's mythopoeic project in Birthday Letters. As Hughes attempts to wrestle 'the facts of his life' back from Plath's writings and the various biographies about her, he recognises the partiality and inadequacy of his own understanding of the life he attempts to reclaim. In the Birthday Letters poem, 'Visit', Hughes tells Plath: "It is only a story. Your story. My story" (BL.9). In doing so, he recognises that Birthday Letters is a story rather than history and acknowledges that there are several versions of the story: his version, Plath's version, and the version that is represented by the biographical, literary, and political discourses about these events.

154 'Modern Confessional Writing'. 19. 


\section{Subjectivity}

Hughes was confronted with many subjective accounts of his marriage over the years, both in Plath's writings and in those writings about her, and so we should not be surprised that in Birthday Letters he is so concerned with the inherent uncertainty of his own autobiographical accounts. The poems can be seen as falling roughly into two positions of partiality. The poems appearing earliest in the sequence are generally narrative poems that record specific autobiographical events (e.g. 'Fulbright Scholars', '18 Rugby Street', 'Fidelity', 'Fate Playing' and 'Chaucer'). In these poems, Hughes repeatedly advertises the subjectivity of the story he relates and presents himself as an imperfect, uncertain, and irresolute narrator. The later poems in the sequence, which begin once the hallucinatory terms of Plath's mythopoeic drama have been established, portray the reality of events on a purely mythopoeic level, as in Plath's late poems (e.g. 'The Shot', 'Trophies', 'God Help the Wolf after Whom the Dogs Do Not Bark', 'The Bird', 'The Minotaur', 'Suttee', 'Setebos', 'The Bee God', 'Being Christlike', 'Fairy Tale', 'The Blackbird', 'Totem', 'Blood and Innocence', 'Costly Speech', 'Night Ride on Ariel', 'Telos', 'Brasilia', 'The Cast', 'The Ventriloquist', 'The God' and 'Red'.)

In this chapter we will only be looking at the narrative poems that relate to specific autobiographical events and that advertise their own subjectivity. However, it is worth pointing out that because these poems appear earlier in the Birthday Letters sequence they should be understood as a kind of introductory disclaimer to the sequence, as a signal to the reader that the truth or meaning of the later mythopoeic poems should be understood as mythos rather than logos; as having value in a relative sense, coexisting with, and being in contention with the subjective vision in Plath's late poems.

Hughes advertises the fallibility of his narrative in Birthday Letters through repeated confessions of uncertainty about his ability to remember events accurately. This doubt is not simply a result of the duration of time that has passed since the events occurred, but frequently expresses a suspicion that the speaker's memories are being reordered retrospectively by his imagination to become more coherent. 'Fulbright Scholars', the opening poem of Birthday Letters, immediately alerts the reader to these 


\section{Subjectivity}

problems. Significantly, the sequence begins not with an assertion of fact - but with a question:

Where was it, in the Strand? A display

Of news items, in photographs

For some reason I noticed it.

A picture of that year's intake

Of Fulbright Scholars. Just arriving -

Or arrived. Or some of them.

(BL. 3)

Birthday Letters opens with an expression of uncertainty. Hughes recollects this

photograph, but cannot remember where he saw it, or, indeed, whether he saw it at all, and he suspects that he may have invented the memory (perhaps after seeing a photograph of some other Fulbright Scholars) in the intervening years. Even if he did see the photograph, he cannot be sure whether Plath was in the picture. Nevertheless, in spite of these uncertainties, he must go on with his narrative and imagine how things might have occurred, how things seem to have occurred:

Were you among them? I studied it,

Not too minutely, wondering

Which of them I might meet.

I remember that thought. Not

Your face. No doubt I scanned particularly

The girls. Maybe I noticed you.

Maybe I weighed you up, feeling unlikely.

Noted your long hair, loose waves -

Your Veronica Lake bang. Not what it hid.

It would appear blond. And your grin.

Your exaggerated American

Grin for the cameras, the judges, the strangers, the frighteners.

Then I forgot. Yet I remember 


\section{Subjectivity}

The picture: the Fulbright Scholars

(BL. 3)

In addition to foregrounding the partiality of the Birthday Letters narrative, 'Fulbright Scholars' also provides our first impressions of the sequence's two central characters - Hughes and Plath. The impressions Hughes gives us of Plath in this poem, are constructed retrospectively, and are therefore, in terms of the drama in the poem, as artificial as the persona he attributes to her. Hughes's knowledge of Plath is, of course, not derived from this photograph, for he has not yet met her. He is not even sure that the photograph existed. Indeed, Hughes confesses "it seems unlikely" that the Fulbright scholars would "have come as a team" (BL.3). Nevertheless, accepting the fictive terms of our introduction to Plath, we are immediately presented with another example of the false image. In 'Fulbright Scholars', Plath's appearance appears as a façade erected to hide the fears that had already led her to one breakdown and her suicide attempt of 1953. As the poem progresses, 'Fulbright Scholars' does not offer any alternative explanations for Hughes's "unlikely" memory but presses on reconstructing, where necessary, the unmediated impressions of his memory and attempting to give them some coherence. While we cannot say that this event described in 'Fulbright Scholars' is a true account, it is clear that the event, or the impression of having experienced such an event, is real in a subjective sense, and has the force and coherence of fact in terms of its significance for Hughes. Making sense of events in one's own life is always a subjective project and always involves constructing a narrative of some sort by selecting events and placing them into some sort of order, and Hughes's imaginative vision in 'Fulbright Scholars' highlights this insight. Furthermore, the poem's position as the first poem within the larger narrative and vision of Birthday Letters highlights the unreliability of the narrative that follows. Hughes describes himself as ignorant and over-confident in 'Fulbright Scholars' and Ann Skea has likened Hughes's self-characterisation here to the archetypal 'fool' of the tarot pack, about to set forth on his adventure from ignorance towards enlightenment. ${ }^{155}$ The main function of this poem, aside from introducing the main characters of the drama, is to highlight the uncertainty and his partiality of the narrative that will follow.

${ }^{155}$ Ann Skea. 'The Path of the Fool - Alph' can be found online at: http://ann.skea.com/TheFool.htm 


\section{Subjectivity}

This concern with the unreliability of confessional (and biographical) writings remains central throughout Birthday Letters. In '18 Rugby Street', for example, in which Hughes describes how their friend Lucas Myers helped arrange their first meeting (following their brief encounter at the St Boltoph's party), the narrative is disturbed by several gaps in the narrator's memory as to how events took place that evening. For example, in his description of Plath's entry to the flat:

\section{I can hear you}

Climbing the bare stairs, alive and close,

Babbling to be overheard, breathless.

That was your artillery, to confuse me:

Before coming over the top in your panoply

You wanted me to hear you panting. Then -

Blank. How did you enter? What came next?

How did Lucas delete himself, for instance?

(BL. 22)

Later in the same poem, Hughes recalls going back to Plath's hotel room, yet admits, "I cannot remember / how I smuggled myself, wrapped in you. / Into the hotel” (BL.24). Similar confessions occur in later poems such as 'Chaucer', in which Hughes recalls Plath reciting Chaucer's 'The Wyf of Bath' to a herd of cows that inexplicably crowd around her to listen. After Plath's recital, Hughes confesses that he cannot recall what happened next:

How did you stop? I can’t remember

You stopping...

(...)

\section{What followed}

Found my attention too full

And had to go back into oblivion. 


\section{Subjectivity}

These descriptions of forgetfulness do not contribute to the drama of Birthday Letters in any way. The reader does not need to know how Lucas 'deleted himself' from Rugby Street, how Hughes smuggled himself into Plath's hotel room, or what happened after the poetry recital recorded in 'Chaucer'. The details of forgetfulness are extraneous to the events being described but Hughes makes a conscious decision to include these to highlight the unreliability of the confessional mode he has adopted, to ensure there is no mistaking such poems as historical record. This is not to say that he believes these personal memories are any the less valuable than fact. These memories are unique and valuable because they provide access to a version of the 'real' Plath that is unmediated except through his subjectivity. In 'Daffodils', for example, he points out that his narrative is privileged in the sense that it records experiences that he and Plath shared that cannot be provided by anyone else:

Remember how we picked the daffodils?

Nobody else remembers, but I remember.

Your daughter came with her armfuls, eager and happy,

Helping the harvest. She has forgotten.

She cannot even remember you.

In 'Daffodils', as in 'Fulbright Scholars' and 'The $59^{\text {th }}$ Bear', Hughes is retrospectively transforming the uncertainty of his memories into something coherent and meaningful. On this occasion the daffodils become a symbol of how precious and fleeting these private moments are:

Our lives were still a raid on our own good luck.

We knew we'd live for ever. We had not learned

What a fleeting glance of the everlasting

Daffodils are. Never identified

The nuptial flight of the rarest ephemera -

Our own days!

We thought they were a windfall. 


\section{Subjectivity}

Never guessed they were a last blessing.

(BL.127)

In 'Daffodils' Hughes offers an uncertain memory of himself and Plath sharing an experience but other Birthday Letters poems show them experiencing the same event in very different ways. In Birthday Letters meaning and significance are not part of the objective world but are created as the subjective inner world processes the individual's experience. 'Your Paris' offers a good example of this problem by highlighting Hughes's and Plath's conflicting experiences of Paris while there on honeymoon.

In 'Your Paris', Hughes recalls Plath meeting the city with "a shatter of exclamations" (BL.36). Plath's version of Paris, he suggests, was the city that had inspired so many ex-pat American writers "Hemingway, / Fitzgerald, Henry Miller, [and] Gertrude Stein" (BL.36). While Plath seems to be quite at home in her 'American' Paris, Hughes, is uneasy, and in foreign territory. In Hughes's Paris, the horrors of the Second World War and the Holocaust still haunt the streets that had been occupied by the Nazis only 13 years previously:

I kept my Paris from you. My Paris

Was only just not German. The capital

Of the occupation and old nightmare.

I read each bullet scar in the Quai stonework

With an eerie familiar feeling...

While for Hughes, Paris is haunted by the Nazis, Plath is apparently undisturbed by these recent historical events and appears enthralled with the city of her literary education:

\section{While you}

Called me Aristide Bruant and wanted

To draw les toits, and your ecstasies ricocheted

Off the walls patched and scabbed with posters -

I heard the contrabasso counterpoint 


\section{Subjectivity}

In my dog-nosed pondering analysis

Of café chairs where the SS mannequins

Had performed their tableaux vivants

So recently the coffee was still bitter

As acorns, and the waiters' eyes

Clogged with dregs of betrayal, reprisal, hatred.

I was not much ravished by the view of the roofs.

My Paris was a post-war utility survivor,

The stink of fear still hanging in the wardrobes,

Collaborateurs barely out of their twenties,

Every other face closed by the Camps

Or the Maquis. I was a ghostwatcher

My perspectives were veiled by what rose

Like methane from the reopened

Mass grave of Verdun.

Hughes's vision of Paris is clouded by the Nazi atrocities and their recent occupation of Paris, while Plath's is apparently coloured by her literary studies. He cannot help but express some distaste at her insensitivity to the recent horrors of the Second World War and the Holocaust. He connects her attitude to her being American, to her expensive sanitised education, and to the insensitivity that enables her to translate the Nazis and the Holocaust into symbols that can be utilised in her art. To Hughes, Plath's attitude suggests a conflation of art and reality:

For you all that

Was the anecdotal aesthetic touch

On Picasso's portrait

Of Apollinaire, with its proleptic

Marker for the bullet. And wherever

Your eye lit, your immaculate palette,

The thesaurus of your cries, 


\section{Subjectivity}

Touched in its tints and textures.

(BL.36-7)

Up until this point, Hughes certainly appears to be privileging his version of Paris over Plath's. This attitude has been noted, and criticised by several writers, such as Anna Jackson who argues that Hughes juxtaposes his and Plath's perspectives of Paris in order to demonstrate his English superiority over the American Plath: "He wants to 'humour' Plath, whose American nationality is itself represented as a joke." ${ }^{156}$ However, after Hughes has established this tone of superiority in 'Your Paris', he makes a sudden volte face and confesses that, after reading Plath's journals (following her death), he learned that he had completely misunderstood her reaction to Paris. Looking back, Hughes now interprets Plath's "gushy burblings" as a façade that she performed in order to hide from him how her Paris was also haunted by the horrors of the recent past. The city was a constant reminder of her recent heartbroken search for her lover Richard Sassoon, who, he conjectures, she feared would appear from round some corner at any time:

\section{Your lingo}

Always like an emergency burn-off

To protect you from spontaneous combustion

Protected you

And your Paris. It was diesel aflame

To the dog in me. It scorched up

Every scent and sensor. And it sealed

The underground, your hide-out,

That chamber, where you still hung waiting

For your torturer

To remember his amusement.

In her Journals, Plath describes the agony of coming to Paris to confront Sassoon only to find he had left his last known address, where she found her last letters to him

\footnotetext{
156 Jackson, Anna. 'Sylvia Plath's "Exaggerated American Grin”: Anti-American Sentiment and the Reception of Plath's Poetry'. Journal of Transatlantic Studies, 5(2) 2007, 117-132.
} 


\section{Subjectivity}

unopened. The title 'Your Paris', now becomes less of an assertion, and more of a question, like the opening line of Birthday Letters. Which version of Paris was in fact her Paris? There are three versions in this poem: Hughes's version - that is haunted by the Nazis, the version Hughes interprets from Plath's outward behaviour, and the version she privately describes in her Journals. Recalling his earlier impressions, Hughes now confesses that his earlier understanding of Plath's view of Paris as shallow and insensitive was wrong because her real impressions were hidden from him in her habit of suppressing her fears:

\section{Your practised lips}

Translated the spasms to what you excused

As your gushy burblings - which I decoded

Into a language, utterly new to me

With conjectural, hopelessly wrong meanings -

You gave me no hint how, at every corner,

My fingers linked in yours, you expected

The final face-to-face revelation

To grab your whole body. Your Paris

Was a desk in a pension

Where your letters

Waited for him unopened.

Hughes's suggestion that he was not aware of Plath's inner torment while in Paris implies that he was similarly unaware of her inner-turmoil in other, more urgent situations that occurred later in their relationship. Plath's Journals support Hughes's suggestion that she hid her insecurities from him because she believed that they made her appear weak and she did not want to become reliant on him for reassurance. In one 1957 entry, for example, she writes:

Keep quiet with Ted about worries. With him around, I am disastrously tempted to complain, to share fears and miseries. Misery loves company... Confiding in 


\title{
3 Subjectivity
}

him is my worst weakness. I feel he deserves to bear my pain and share it, but I must shoulder my aloneness somehow, and begin to be nobler. ${ }^{157}$

As Hughes begins to describe Plath's hidden inner world in 'Your Paris', he slips into the mythopoeic mode he employs throughout the later poems where this inner world imposes itself more vividly onto Plath's apprehension of the outer world, and consequently on their story. Retrospectively, having read Plath's journals, and having interpreted the psychological drama that emerged in her late poems, Hughes knows that Plath's Paris:

\begin{abstract}
Was a labyrinth
Where you still hurtled, scattering tears.

Was a dream where you could not

Wake or find the exit or

The Minotaur to put a blessed end

To the torment. What searching miles

Did you drag your pain

That were for me plain paving, albeit

Pecked by the odd, stray, historic bullet.
\end{abstract}

In the second half of 'Your Paris', the contrast between Hughes's and Plath's visions has changed considerably. It is now Plath who hides her Paris from Hughes to protect him. In contrast to Plath's vision of Paris as a labyrinth, Hughes's own impressions are now quite prosaic. The "searching miles" of street over which Plath drags her "torment" are for Hughes "plain paving" that is "pecked by the odd, stray, historic bullet" (BL.38).

The following poem, 'You Hated Spain', is also set during Hughes's and Plath's honeymoon and repeats the assertion made in 'Your Paris' that although Hughes and Plath travelled together, their experiences of the same places and events were utterly different. In 'You Hated Spain', Hughes and Plath find that Spain is a country that

157 'The Journals'. 622-3. 


\section{Subjectivity}

resonates with their 'poetic selves' and their inspiration, but in the same way that their inspiration is different, so are their experiences. In Spain Hughes "felt at home" as the primitive, slightly savage "African / Black edges" resonated with the uncivilised energies he was attempting to capture in his poems to compete with what he saw as the tyranny of civilisation (that is exemplified by his horror in 'Your Paris'). For Plath, however, Spain was the land of her nightmares. She recognised in the landscape and culture something that corresponded with her inner life. Spain connects her with the primitive uncivilised part of her psyche that remained unfettered by her American education; it is "the juju land behind [her] African lips" (BL.39). Like the visionary painters Hieronymus Bosch $^{158}$ and Francisco Goya ${ }^{159}$ (whose work they may well have encountered in the Prado Museum in Madrid), Plath glimpsed, in Spain's shadow, an archetypal vision of death and the after world:

\section{Spain frightened you. Spain}

Where I felt at home. The blood-raw light,

The oiled anchovy faces, the African

Black edges to everything, frightened you.

Your schooling had somehow neglected Spain.

The wrought-iron grille, death and the Arab drum.

You did not know the language, your soul was empty

Of the signs, and the welding light

Made your blood shrivel. Bosch

Held out a spidery hand and you took it

Timidly, a bobby-sox American.

You saw right down to the Goya funeral grin

And recognised it, and recoiled

As your poems winced into chill, as your panic

Clutched back towards college America.

\footnotetext{
${ }^{158}$ Hieronymus Bosch's (1450-1516) paintings often depicted fantastic and nightmarish metaphysical and/or religious landscapes. Bosch is probably most famous for his Garden of Earthly Delights.

${ }^{159}$ Francisco Goya (1746-1828) is famous for the subjective, macabre, mythopoeic nightmarish visions, including a study of isolation and loneliness in Courtyard of Lunatics (depicting a mental asylum) and The Colossus.
} 


\section{Subjectivity}

$(\ldots)$

$$
\text { Spain }
$$

Was the land of your dreams: the dust-red cadaver

You dared not wake with, the puckering amputations

No literature course had glamorized.

The juju land behind your African lips.

Spain was what you tried to wake up from

And could not.

Hughes's and Plath's experiences of Spain are different because of their very different temperaments and the way the country coincided with their inner worlds. According to Hughes, Spain provided Plath with the light, colour and imagery for the surrealist landscapes in her Ariel poems, he described in a 1965 essay as "a landscape like that of the Primitive Painters, a burningly luminous vision of a Paradise. A Paradise which is at the same time eerily frightening, an unalterably spot-lit vision of death." ${ }^{160}$ In Spain, Plath encounters the nightmare vision that she shares with other visionaries such as Bosch and Goya, but she is not yet ready to face it, as she will later do in her poems. It is a vision that hints at the frightening psychological battle that needs to take place.

While 'Your Paris' and 'You Hated Spain' respond to the subjective vision that will eventually characterise Plath's writings, several other Birthday Letters poems, while addressing Plath directly, reply to the interpretations of Plath's work by her critics and biographers. One such poem is the 'The Rabbit Catcher', which responds to Plath's poem of the same title. As in 'The Fifty-Ninth Bear', Hughes's response to Plath in 'The Rabbit Catcher' is more properly autobiographical than Plath's original. ${ }^{161}$ Hughes's intention, it seems, in placing the poem back into its biographical origin, is to close down

\footnotetext{
160 'Winter Pollen'. 160. Richard Tillinghast also suggested Plath's poems should be considered "alongside such psychotic visual art as the demonic fantasies of Bosch, Goya's Pinturas Nigras, Piranesi's Carceri d'Invenzione, and Lois Wain's kaleidoscopic cats in his 1969 essay, 'Worlds of Their Own'. Southern Review, Spring 1969, 582-3 Reprinted in: Linda Wagner-Martin's The Critical Heritage ${ }^{161}$ Similarly, the Birthday Letters poem 'Black Coat' place Plath's 'Man in Black' in an autobiographical context.
} 


\section{Subjectivity}

the speculations by biographers and literary critics concerning the poem's origin and meaning. ${ }^{162}$

One reading of Plath's 'The Rabbit Catcher' that particularly upset Hughes appeared in Rose's The Haunting of Sylvia Plath. Rose interpreted 'The Rabbit Catcher' as a critique of the inherent violence within heterosexual sexual relationships. Plath's poem is a monologue in which the speaker wanders through a landscape which leads to a perfumed hollow that has been set with rabbit snares. Rose reads the description of this landscape as a metaphor for "the woman's body as trap"163 and suggests that in this section Plath is fantasising about sexual desire from a male orientation. However, as the poem progresses, the symbol of male sexual desire becomes the rabbit catcher who set the traps in the hollow, and who is "excited" as he awaits the "little deaths" of the rabbits that "waited like sweethearts" (SPC.194). Rose interprets this drama as a fantasy about being the recipient of male violence ("it is impossible not to recognise in that link between torture, efficiency, beauty and extravagance a sexualising and aestheticising of power"164). She argues that the speaker of the poem is ambivalent in being both appalled and enthralled by this power and explains her complicity as being a result of having "roots too deep to uproot, and a mind like a ring" (SPC.194). Rose suggests this is a description of the internalisation of the 'normal' heterosexual values that vindicate this ongoing violence. In other words, Rose interprets Plath's 'The Rabbit Catcher' as “a complaint against heterosexuality" which agues that "sexuality is a trap". ${ }^{165}$ Although Rose bases her interpretation of the poem on the poem's internal evidence rather than on biographical speculations about the conditions surrounding its composition, when she approached the Plath estate for permissions to quote from Plath's works, her reading of 'The Rabbit Catcher' became "the object of heated and unresolved dispute" with Ted and Olwyn Hughes. As she says in the preface to The Haunting of Sylvia Plath:

\footnotetext{
162 Diane Middlebrook has also pointed out that Plath's 'The Rabbit Catcher' is a response to D.H. Lawrence's 'Rabbit Snared in the Night', which also uses sexual metaphors.

163 'The Haunting of Sylvia Plath'. 139.

164 'The Haunting of Sylvia Plath'. 137.

165 'The Haunting of Sylvia Plath'. 140.
} 


\section{Subjectivity}

In correspondence with the Hughes's, this book was called 'evil'. Its publisher was told it would not appear. At one point an attempt was made to revoke previously granted permissions to quote from Plath's work. I was asked to remove my reading of 'The Rabbit Catcher', and when I refused, I was told by Ted Hughes that my analysis would be damaging for Plath's (now adult) children and that speculation of the kind I was seen as engaging in about Sylvia Plath's sexual identity would in some countries be 'grounds for homicide'. ${ }^{166}$

As I have already said, Rose defended her reading on the grounds that "interpretation of a literary work is endless", and pointed out that "once a piece of writing has been put into circulation, it ceases - except in the most material sense - to be the property of its author. Nor can it be controlled and limited by the views of any one individual, no matter how close to the subject they may have been, or feel themselves to be."167 Rose went on categorically to defend her interpretations in The Haunting of Sylvia Plath as literary criticism, rather than biographical speculation:

This is not a biography. I am never claiming to speak about the life, never attempting to establish the facts about the lived existence of Sylvia Plath. First, because what I am interested in is writing, in what - independently of a writer's more concretely lived reality - it can $d o$; secondly, because accounts of the life and nowhere has this been demonstrated more clearly than in relation to Plath have to base themselves on a spurious claim to knowledge, they have to arbitrate between competing and often incompatible versions of what took place. ${ }^{168}$

In addition to reassuring readers that her interpretation of 'The Rabbit Catcher' does not say anything about the "lived experience" of Plath, Rose also points out that accounts of Plath's (and Hughes's) life are based "on a spurious claim to knowledge" and, as we have seen, the biographers (and Hughes and Plath themselves) cannot always be trusted to distinguish between fact and fiction. As Rose states elsewhere in The

\footnotetext{
166 'The Haunting of Sylvia Plath'. xiii.

167 'The Haunting of Sylvia Plath'. xi.

168 'The Haunting of Sylvia Plath'. xi.
} 


\section{Subjectivity}

Haunting of Sylvia Plath, "it is impossible to read Plath independently of the frame, the surrounding discourses, through which her writing is presented." ${ }^{\prime 169}$ This insight is supported by the biographical readings of Plath's 'The Rabbit Catcher' that follow.

Much has been made of the biographical circumstances surrounding Plath's composition of 'The Rabbit Catcher'. Although the poem was originally in Plath's Ariel manuscript, Hughes withheld the poem from Ariel in 1965 and did not publish it until Winter Trees (1971). Plath wrote 'The Rabbit Catcher' along with another poem, 'Event', on $20^{\text {th }}$ May 1962, the day after Assia and David Wevill made a weekend visit to Hughes and Plath at Court Green for the weekend ( $18^{\text {th }}$ and $19^{\text {th }}$ May). The weekend visit ended on a sour note and in the following month, Hughes began an affair with Assia Wevill. In Bitter Fame, Stevenson suggests that the Wevills' visit became strained when Plath's mood changed dramatically. David Wevill interpreted Plath's mood as being a consequence of her being unable to sustain too much sociability so soon after the birth of Nicholas, but Stevenson adds: "Assia confided to Suzette Macedo that Sylvia had picked up 'a current of attraction' between Assia and Ted and had reacted badly."170 Stevenson tempers this additional information about Assia's and Hughes's attraction with the further information "Suzette is sure that nothing of a more romantic nature happened that weekend." ${ }^{\prime 71}$ Alexander, on the other hand, who again gives no sources for his account of that weekend, suggests that Assia seduced Hughes that weekend in the most dramatic terms: "Strong-willed and determined, Assia - apparently - made the first move with Ted. On the morning of the Wevills' stay, as Sylvia would later contend, Assia came downstairs to discover Ted sitting alone at the kitchen table drinking a cup of coffee. Creeping up behind him, she lifted her nightgown to her chin, released it to flutter down over his face and torso, and trapped him inside the nightgown with her."172 Plath's biographers suggest this weekend visit by the Wevills was the catalyst for Plath's subsequent poems. For example, as Wagner-Martin writes: "the day after [the Wevills] left, Sylvia wrote two angry revealing poems, 'The Rabbit Catcher' and 'Event' ... The

\footnotetext{
169 'The Haunting of Sylvia Plath'. 69.

170 'Modern Confessional Writing'. 16.

171 'Bitter Fame'. 243.

172 'Rough Magic'. 276-7.
} 


\section{Subjectivity}

original draft of 'The Rabbit Catcher' includes autobiographical details that Sylvia deleted from the final version. The young wife of the rabbit catcher dreams of an ideal marriage that will allow her freedom to become herself. Once married, however, she finds her husband maintains rigid control over her life. In the poem, however, she does not complain..." Anne Stevenson also suggests the poems are autobiographical and suggests that: "For the first time... Sylvia was using her own husband and offspring for material in a confessional way." 174

These biographical readings of 'The Rabbit Catcher' and 'Event' as autobiographical poems privilege uncertain biographical information over the material within the poems themselves. Although the poems are about the difficulties in a relationship, no partner is presented as being the victim of the other. As Brain explains:

To read these poems as mere confessional responses to the weekend is to avoid the more important story the poems are telling: a story that Plath makes bigger than herself, and which contradicts any confessional narrative of the woman as lone victim. If the marriage hadn't gone wrong and ended, biographers wouldn't present the Wevill's visit as they primarily do, with distorting hindsight, and then squeeze 'The Rabbit Catcher' and 'Event' into a mould they do not fit: of a wife decrying her adulterous husband. ${ }^{175}$

In Hughes's opinion, providing biographers with corrective facts only resulted in further speculation, as he said in a letter to the Guardian: "the truth simply tends to produce more lies... The Fantasia about Sylvia Plath is more needed than the facts."176 Given the nature of his concerns, it is interesting to note that his responding Birthday Letters poem 'The Rabbit Catcher' links Plath's poem to a biographical event. Hughes appears to be attempting to close down the "endless" possibilities of interpretation that

\footnotetext{
${ }^{173}$ Wagner-Martin, Linda W. Sylvia Plath: A Biography. London: Chatto \& Windus, 1987. Hereafter referred to as 'Sylvia Plath: A Biography'.

174 'Bitter Fame'. 244.

175 'Modern Confessional Writings'. 17.

${ }^{176}$ Hughes, Ted. Letter to The Guardian 'The place where Sylvia Plath should rest in peace'. 20 April 1989. Quoted in: 'The Haunting of Sylvia Plath'. 66.
} 


\section{Subjectivity}

Rose describes, and the biographical "fantasia" he saw connected with the poem.

Nevertheless, in representing the event as biographical, Hughes maintains a steady focus on his and Plath's subjectivity in terms of the way they both experience the biographical incident behind the poem.

Hughes's 'The Rabbit Catcher' begins by describing, with typical uncertainty, the aftermath of an argument between Plath and himself: "It was May. How had it started? What / Had bared our edges?" (BL.144) Although Hughes cannot remember how their disagreement occurred, he does recall the "simmering truce" that followed as the couple drove towards the West coast of Southern England:

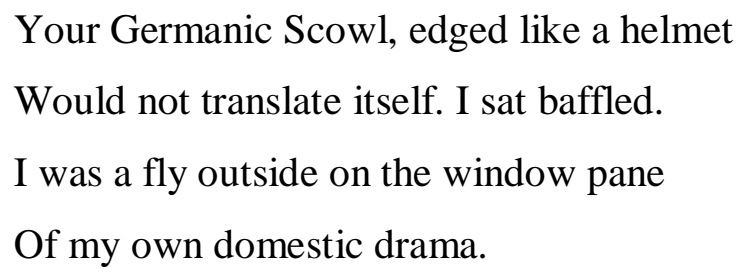

Throughout Birthday Letters Hughes reverses the antagonistic roles of oppressor and victim in Plath's dramatic poems, where he appears as "a Man in Black with a Meinkampf look" (SPC.224), by linking Plath's German ancestry with images of German soldiers from the Second World War. ${ }^{177}$ In 'The Rabbit Catcher', however, this metonymic reference to Plath's German background also emphasises Hughes's difficulty in 'translating' her "fury". ${ }^{178}$ His inability to translate Plath's rage in 'The Rabbit Catcher' is part of a larger narrative in Birthday Letters about the irreconcilability of his and Plath's shared experiences. In 'The Rabbit Catcher', Hughes describes Plath as being angry but he cannot determine why. She appears incensed, for example, at the fenced-off regions of the English coast that block their path as they try and locate the sea:

You

\footnotetext{
${ }^{177}$ For example in '18 Rugby Street': "That was your artillery, to confuse me: / Before coming over the top in your panoply” (BL.22). Similarly, 'A Picture of Otto' uses the scenario described in Wilfred Owen's wartime poem 'Strange Meeting' where an English and German soldier meet in Hell.

${ }^{178}$ This can also been as a echo of a motif in Plath's poems in which she describes being unable to translate her father's German: ('Little Fugue' (SPC.188), 'Daddy' (SPC.222)).
} 


\section{Subjectivity}

Raged against our English private greed

Of fencing off all coastal approaches.

Hiding the sea from roads, from all inland.

You despised England's grubby edges when you got there.

That day belonged to the furies.

When they finally arrive at the coast, they head towards what Hughes describes as a "perfect" place to picnic, "an eerie hollow, just under the cliff-top". But Plath remains unsatisfied with this location and insists they move on:

You refused to lie there

Being indolent, you hated it.

That flat draughty plate was not an ocean.

You had to be away and you went. And I

Trailed after like a dog...

(BL. 145)

As they move across the cliff top, Hughes describes finding a copper-snare in the grass, which Plath suddenly "without a word" tears up and throws into the trees. Hughes suggests that Plath identifies with the rabbit victims of the snares, whereas he imagines the rabbit catcher as a poor peasant who is also a victim of the land enclosures that Plath complained against earlier in the poem. Hughes links himself to the rabbit catcher because they both share a strong connection to the English land, rather than because they both share a penchant for violence, as in Plath's poem. Another disagreement then ensues as Hughes's and Plath's perspectives clash:

I was aghast. Faithful

To my country gods - I saw

The sanctity of a trapline desecrated.

You saw blunt fingers, blood in the cuticles,

Clamped around a blue mug. I saw

Country poverty raising a penny, 


\section{Subjectivity}

Filling a stewpot. You saw baby-eyed

Strangled innocents, I saw sacred

Ancient custom. You saw snare after snare

And went ahead, riving them from their roots

And flinging them down the wood. I saw you

Ripping up the precarious, precious saplings

Of my heritage, hard-won concessions

From the hangings and the transportations

To live off the land. You cried: 'Murderers!'

You were weeping with a rage

That cared nothing for rabbits.

(BL. 145-6)

In 'The Rabbit Catcher' as in other Birthday Letters poems (such as 'Your Paris') the disparity between Hughes's and Plath's reactions to everyday events signal their irreconcilable differences. Retrospectively, he speculates that her anger was perhaps a result of her sense of the growing distance between them, an anticipation of his 'abandonment' of her:

In those snares

You'd caught something.

Had you caught something in me,

Nocturnal and unknown to me? Or was it

Your doomed self, your tortured, crying,

Suffocating self? Whichever,

Those terrible, hypersensitive

Fingers of your verse closed around it and

Felt it alive. The poems, like smoking entrails

Came soft into your hands.

(BL. 146)

Here, Hughes translates the image of the rabbit catcher's hands in Plath's poem to suggest her ability to 'trap' and 'capture' situations from her everyday life in her art. In 


\section{Subjectivity}

this poem, Hughes suggests that it is he who is caught in the snare of Plath's poem, he is in the place of the rabbit and Plath takes the role of the rabbit catcher, crafting a poem that closes on him like a ring. ${ }^{179}$ Thus, Hughes reverses the power relations Rose describes in her interpretation of Plath's poem by distinguishing between his and Plath's subjective experiences.

The preoccupation with subjectivity that pervades Birthday Letters undermines the metaphysical notion that a shared objective reality exists beyond the subject's personal experience. Instead, the world is presented as a palimpsest that can be written upon by the individual. In 'The Blackbird', for example, Hughes describes Plath looking out of the window onto the lawn outside their house constructing her poem 'The Jailer':

The lawn lay like the pristine waiting page

Of a prison report.

Who would write what upon it

I never gave a thought.

Throughout Birthday Letters Hughes presents Plath as the writer who turned "life to paper" (BL.94) because of the autobiographical nature of her art. In Wallace Stevens's famous poem there are thirteen ways of looking at a blackbird but in Plath's poems there is only one. Her subjective perceptions are the only available reality and the world is trapped within her subjectivity. This is an idea Hughes articulates in 'Drawing', a poem that recalls Plath sketching a picture of a market in Benidorm while they are on honeymoon in 1957. 'Drawing' recalls Plath's poem 'The Jailer', in describing how Plath takes objects and scenes from the objective outer world and freezes them into the subjective vision immortalised in her art:

Drawing calmed you. Your poker infernal pen

Was like a branding iron. Objects

\footnotetext{
${ }^{179}$ In 'Caryatids (1)' Hughes describes the first poem he ever read of Plath's as being an unsprung trap: "It seemed thin and brittle, the lines cold. / Like the theorem of a trap, a deadfall - set. / I saw that. And the trap unsprung, empty." (BL.4)
} 


\section{Subjectivity}

Suffered into their new presence, tortured

Into final position.

$(\ldots)$

You drew doggedly on, arresting details,

Till you had the whole scene imprisoned.

(BL. 44)

Hughes describes the objects and people Plath places in her art as being "arrested", "imprisoned", and being held unwillingly in their "final position" without right of reply.

Plath's poems are no different to any other great work of art in this sense but because Hughes (like Aurelia and Otto Plath) features prominently in these poems he is also transformed and cast in the role 'The Jailer' and 'The Rabbit Catcher' and is forced to perform the dramatic roles she assigns him in her poems. In addition to highlighting this tyrannical nature of Plath's art, Hughes reverses the dramatic terms of Plath's 'The Jailer', casting Plath in the role of jailer (of reality) and himself as the prisoner (of her art). In doing so, he signals that throughout Plath's poems, as in Birthday Letters, the assignment of such roles is subjective and partial. 


\section{Fate}

One of the most common criticisms of Birthday Letters has related to Hughes's use of 'Fate' within the sequence. Critics have pointed out that, within Birthday Letters, the characters' actions appear to be pre-ordained and beyond their control. The terms 'fatalism' and 'determinism' are often used interchangeably in this criticism but the distinction between the two is important.

'Fatalism' refers to the notion that the events and decisions in human lives have been predetermined, leaving no way for humans to change their actions. The fatalistic view, though not exclusively Greek, can be traced to the ancient Greeks, the myth of Oedipus being a good example. According to this myth, Oedipus learned he was destined to kill his father and marry his mother and the precautions he took to prevent this happening ensured his Fate did occur. Another example is offered in Homer's Iliad. Achilles knows that if he goes to Troy he will die young, as do his mother Thetis and the Olympians, but none of the Olympians can interfere with his Fate, not even Zeus. This is because, although the Olympians were powerful, the Greeks still remembered an older triad of goddesses called the Moirae (the Fates). In his Theogony, Hesiod tells us that the triad are weavers who control the destinies of all mortals. Clotho ('spinner') spun the thread of human life, Lachesis ('Apportioner of Lots') measured and allotted the length for each individual and Atropos ('she who cannot be turned') snipped the thread with her scissors. According to Hesiod the Three Fates were the daughters of Night ${ }^{180}$ and therefore we can see that they are a version of the great mother whose image is ubiquitous among early human art. As we saw in chapter 2 ('Myth'), Jung believed that early humans were aware that human behaviour was not solely motivated by conscious volition but by other forces (the unconscious) and outer forces (nature) that are both creative and destructive and the great mother was often a symbol of this recognition. We have already linked the Great Mother to the White Goddess, who was a triad in her triple

\footnotetext{
${ }^{180}$ Hesiod gives two separate genealogies for the Moirae. They are described as the daughter of Nix (Night) and in another passage they are described as the daughters of Zeus and Themis, which is presumably a later alteration to explain Zeus's authority and patriarchal right to govern the other gods and goddesses.
} 
moon aspect and whom Graves describes as the original muse of poetic inspiration to whom all true poetry is addressed. Consequently, in the mythopoeic poems of Birthday Letters, in which reality is controlled through the hallucinatory subjectivity of Plath's poems, the characters are subject to the will of the White Goddess, the moon-Muse who overlooks and directs the drama in Plath's 'visionary' poems. As Hughes says in 'Flounders', "we / Only did what poetry told us to do" (BL.66).

In contrast to 'fatalism', the notion of 'determinism' does not deny human choice or free-will. However, determinists argue that because we live in a causal universe where everything happens as a result of cause and effect, all choices (actions and events) that occur in the future are the result of past events (causes). In a deterministic universe, if we knew everything about a person, such as Plath, and knew everything that had happened to her in the past, we should be able to predict what will happen to her in the future. The determinism in Birthday Letters is therefore, to some extent, a result of the narrator's (and the reader's) retrospective knowledge of future effects. As Hughes puts it in 'A Short Film', in Birthday Letters we experience "a bracing of nerves / For something that has already happened" (BL.134). This retrospective determinism of Birthday Letters explains the reactions of readers like Pollitt, who, in describing the experience reading the poem 'St Boltoph's' in which Hughes and Plath first meet, said: 'It makes one want to warn both of these very young people to run away and never look back."181 In poems such as 'St Boltoph's', the reader, like the narrator, is observing a drama taking place in 1956 while already knowing what the characters' future holds.

In the introduction we looked at Pollitt's and Wood's criticism of the mythopoeia in Birthday Letters. I return to these reviewers here and introduce Leonard Scigaj's criticism because their views are representative of the general objections relating to Fate and determinism in Birthday Letters. In Wood's 1998 review of Birthday Letters, he points out that in Birthday Letters (and Plath's and Hughes's writings more generally) the natural world is not subject to the ordinary natural laws propounded in contemporary society but by "fixed stars":

\footnotetext{
181 'Peering into the Bell Jar'.
} 
Ted Hughes's poems are bullied almanacs, in which the natural world is forced through a calendar of dark myth and astrological glower... The aura of predestination is the book's strongest texture. The poems find different ways to accuse destiny." 182

Wood complains that Birthday Letters constantly foregrounds impending events through omens and portents that make the following events seem inevitable. For Wood, the problem with Birthday Letters is that Hughes uses myth, folktale and astrology, which distort the authenticity of the historical experiences being described and estrange the poems from their 'real subject' until finally 'the two poets become 'puppets' in a 'Fable',' 183

Wood also argues that Hughes's characterisation of Plath as having never recovered from her father's death amounts to a deterministic explanation for her suicide: "The Plath of these poems is a suicide-bomb, ticking through a doomed marriage, waiting to do good on the botched attempt that she made as a teenager." ${ }^{184}$ He notes that in Birthday Letters "Hughes's language is lavishly collusive with Plath's last poems", that “many of Hughes's later poems seem strongly influenced by Plath's last death-heady poems", and he suggests that Hughes's depiction of Plath as doomed and suicidal "is sometimes Plath's picture of herself... especially in her late verse." ${ }^{185}$ Despite pointing out these strong correlations between Birthday Letters and Plath's poems, Wood does not question whether the determinism in Birthday Letters is the 'particular' subject of the poems he is seeking. He does not consider that the mythopoeic frame of the poems could be Hughes's way of responding to the mythologising of the 'facts' of his life in Plath's writings, and in the discourses that have arisen from these writings.

\footnotetext{
182 'Muck Funnel'. 30.

183 'Muck Funnel'. 30.

184 'Muck Funnel'. 30.

185 'Muck Funnel'. 30.
} 
Pollitt is another critic who disparages Hughes's treatment of fate in her New York Times review of Birthday Letters. Like Wood, she is particularly scathing of the omens that repeatedly foreshadow the tragic events of the story:

Poem after poem has the same plot: an effort at ordinary happiness, pleasure, closeness - a camping trip to Yellowstone, a day at the beach - turns ominous as a symbol (an owl, a bear, a cloud of bats, worms, thunder, a Ouija-board message, a gypsy, a sinister doll) appears on the scene to foreshadow the terrible future. ${ }^{186}$

Yet the "terrible future" Hughes is preparing the reader for throughout Birthday Letters, is not an invention. Plath's suicide and the aftermath of Ariel are inevitable in the sense that, in Birthday Letters, the future has already happened. Hughes's vision in Birthday Letters is retrospectively deterministic in the sense that, as in most of the narratives about Plath, Hughes is looking back from the effect to the causes. In Pollitt's view, the fate and retrospective-determinism of Birthday Letters are simply a way for Hughes to exonerate himself from any responsibility for Plath's suicide:

Incident after incident makes the same point: she was the sick one, I was the “nurse and protector.” I didn't kill her - poetry, fate, her obsession with her dead father killed her. The more Hughes insists on his own good intentions and on the inevitability of Plath's suicide, the less convincing he becomes. One begins to wonder what it means to blame a suicide on Fate, on a father who died, after all, when Plath was 8 years old, or on "fixed stars". Inadequate as it is to see Plath's life in wholly sociological, political terms - the plight of a young female genius in the pre-feminist era - it makes more sense than astrology. ${ }^{187}$

Like Wood, Pollitt also notes that throughout Birthday Letters, Hughes echoes Plath's writings. However, she dismisses these allusions to Plath's writings as derivative and does not see them as serving any purpose within the sequence. Furthermore, she also

\footnotetext{
186 'Peering into the Bell Jar'.
}

187 'Peering into the Bell Jar'. 
argues that while Plath's use of myth in her poems was a way "of suggesting all that is unknowable about another person, tragic about the future and malign about the cosmos", Hughes's use of myth in Birthday Letters attempts "a literal explanation" 188 for the events he describes. For Pollitt, Hughes's fatalism in Birthday Letters distracts readers from the way his actions led to Plath's death. By the same logic, we could argue that, in holding Hughes responsible for Plath's suicide, Pollitt is denying Plath any selfdetermination in her final act.

Like Wood and Pollitt, Leonard Scigaj in his 2004 essay, 'The Deterministic Ghost in the Machine of Birthday Letters', criticises the fatalism of Birthday Letters, in terms of Hughes's foregrounding of omens and portents:

In Birthday Letters (1998) all the omens save Assia's pike dream are bad omens. A pillowstain of blood, a gypsy's curse, a Ouija board, an earthenware head, a possibly rabid bat, a fox cub, a snake, ponderous astrology, and the word "Fate", capitalized many times - all testify to a fatalistic inevitability. These are the "fixed stars" (BL. 118, 152, 188) that led to Plath's suicide. ${ }^{189}$

Scigaj suggests, like Wood, that Hughes's foregrounding of omens and portents in Birthday Letters is a way of making the tragic events that follow seem inevitable. However, as we will see, Hughes's use of omens and portents is much more sophisticated that Scigaj suggests. The omens in Birthday Letters are misread by the characters within the drama, and are only deterministic to the narrator who retrospectively looks back on the action. In this way, Hughes emphasises the way that we make sense of history (and biography) by imposing significance on events retrospectively so that they fit into the evolving subjective narrative of our understanding.

\footnotetext{
188 'Peering into the Bell Jar'.

${ }^{189}$ Scigaj, Leonard. 'The Deterministic Ghost in the Machine of Birthday Letters'. In: Moulin, J. Ted Hughes: Alternative Horizons. Taylor and Francis Group. London. 2004. 1. Hereafter referred to as 'The Deterministic Ghost in the Machine of Birthday Letters'.
} 
Scigaj is also concerned with the determinism in Birthday Letters, which, like Pollitt, he believes is a way for Hughes to avoid responsibility for his own actions:

In Birthday Letters Ted Hughes has created a machine of words, a labyrinth meant to reduce his wife's behaviour to one deterministic cause, and in doing so deflect attention from his actions as well as reaffirm for one last time in print his male control of her actions." 190

Like Pollitt, Scigaj supplements his criticism of Hughes's interpretation of Plath and her writings by presenting the reader with an alternative reading. Scigaj's reading of Plath relies heavily on her novel The Bell Jar, in which, he argues, Esther Greenwood's father's death does not play a central role as it does in Birthday Letters. Scigaj complains Hughes's depiction of Plath as fixated on her father's death does not account for the "struggle for equality" and "self integral freedom" that Plath strives for in The Bell Jar and in many of the Ariel poems. Scigaj interprets Plath's 'Daddy' as a record of a psychological "exorcism of the patriarchal imago inside the dutifully trained, once subordinated, but now rebellious 1950s woman persona", ${ }^{191}$ a reading that replicates Hughes's reading of Plath's individual psychological crisis on a socio-political level. Consequently, according to Scigaj, "the real vampire" killed by the speaker of 'Daddy' is not Hughes or Otto but "the male imago introjected into the female superego as a controlling force", which enables "the freedom to erase the hold that the past has on her psyche, so she can set new self-development goals." 192 However, Scigaj does not explain how Plath achieved this psychological freedom from her past and remained a victim of Hughes's past actions.

Scigaj further suggests that, in Birthday Letters, by repeatedly connecting Plath and her father with images of Germany and the Nazis, Hughes attempts to explain Plath's penchant for "father worship" and her destructive (and self-destructive) behaviour, by implying that she and her father inherited the same genetic traits:

\footnotetext{
190 'The Deterministic Ghost in the Machine of Birthday Letters'. 5.

191 'The Deterministic Ghost in the Machine of Birthday Letters'.10.

192 'The Deterministic Ghost in the Machine of Birthday Letters'.10-11.
} 
Otto himself is infected with fascistic faith in an all-powerful Ruler ... So Plath, his offspring, exhibits in her destructive behaviour that same genetic tendency. Her dreams in Birthday Letters are infected not only with corpses, but with "father worship" and its particular Germanic legacy of Nazi horrors, the "Deathcamp atrocities," the "gas chamber and the oven" (BL.141-42) ... Genetic determinism is how Hughes understands his former wife's bouts of sullenness, her hostility, anger, and her final act of self-violence. Otto's hands are the hands of Fate manipulating Plath's actions (BL.184-5), and those hands function as a perfect incarnation of a German death-wish, a cultural Ragnarok, in World War II. ${ }^{193}$

To Scigaj, Hughes's deterministic vision of Plath in Birthday Letters contradicts the existentialist assertions of self-determined liberation in Plath's poems since "deterministic thinking is absolutely inimical to existential freedom, choice and responsibility." "194 Rather than being at odds with Hughes's use of determinism in Birthday Letters, Scigaj is at odds with his interpretation of Plath's writings. Scigaj suggests that Plath's despair and depression were a result of social forces within the material (outer) world, whereas Hughes sees the forces that Plath contends with as being part of her psychological (inner) world.

Hughes sees Plath's writings as a mythopoeic description of her struggle to redefine and liberate her buried inner voice through a ritual drama of death and rebirth. As he said in a 1995 essay, The Bell Jar is “the author's psychic auto-biography, the creation myth of the new person that had emerged in the 'Poem for a Birthday' and that would go on in full cry through Ariel." Hughes then goes on to describe 'the story' itself:

The Bell Jar is the story, in other words, from behind the Electroconvulsive Therapy. It dramatises the decisive event of her adult life, which was her

193 'The Deterministic Ghost in the Machine of Birthday Letters'. 2-3.
194 'The Deterministic Ghost in the Machine of Birthday Letters'. 4. 
attempted suicide and accidental survival, and reveals how this attempt to annihilate herself had grown from the decisive event in her childhood, which was the death of her father when she was eight... Fully aware of what she was doing, she modelled the sequence of episodes, and the various characters, into a ritual scenario for the heroine's symbolic death and rebirth. To her, this became the crucial aspect of the work. That mythic schema of violent initiation, in which the old self dies and the new self is born, or the false self dies and the true is born, or the child dies and the adult is born, or the base animal dies and the spiritual self is born, and which is fundamental to the major works of both Lawrence and Dostoyevsky, as well as to Christianity, can be said to have preoccupied her. ${ }^{195}$

All that we learn, then, from Scigaj's objections, is that both his and Hughes's versions of Plath are subjective and rely on a interpretation of her writings that determines their meaning. We have already seen that subjectivity is a problem that Hughes self-consciously foregrounds in Birthday Letters. While Scigaj's version of Plath is as valid as Hughes's, in Birthday Letters Hughes is also telling his own story, and if we do not allow him this subjective 'version' of Plath, we deny him the right to interpret his own experiences.

The determinism and fatalism we encounter in Birthday Letters are a reflection of the way Hughes understands Plath's poems translating their historical lives onto a subjective mythopoeic plane. This mythic drama is a mixture of fact and fiction, confuses history and myth, and assigns Hughes and Plath the roles of aggressor and victim respectively. Therefore, rather than seeing Birthday Letters as "inimical to existential freedom" as Scigaj suggests, we might see the sequence as an attempt by Hughes to liberate himself and Plath from the sociological-political readings that have determined the way their actions and characters have been understood since the publication of Ariel.

195 'Winter Pollen: U.S. edition'. 468. 
Scigaj argues that Hughes emphasises Plath's German background by connecting her with images of German soldiers and the Nazis in order to suggest that her character was genetically determined. However, such a reading overlooks how, in this way, Hughes is reversing the dramatic terms of 'Daddy' by casting Plath as the aggressor and himself as the passive victim of her aggression. Furthermore, Scigaj's suggestions about genetic determinism would not equate with Hughes's Jungian notion of a collective unconscious, which transcends racial boundaries and contains psychic memories for millions of years. As Jung himself commented, the collective unconscious should be seen as:

A collective human being combining the characteristics of both sexes, transcending both sexes, youth and age, birth and death, and, from having at its command a human experience of one or two million years, practically immortal. ${ }^{196}$

If, as seems likely, Hughes held this Jungian view of human consciousness, then he would see racial and national differences as negligible. This would explain his portrait of Plath in their first meeting after the St Boltoph's encounter where he describes her as having a mixture of racial characteristics: "And now at last I got a good look at you", he says, describing her brown hooded eyes as "Prussian", ${ }^{197}$ her lips as having an "aboriginal thickness", and her nose as "broad and Apache" from "Attila's horde". Hughes also says that Plath's face "could have looked up at me through the smoke / Of a Navajo fire" (BL. 22-3). Passages such as this, in describing Plath as having a mixed physiognomy that includes genes from Eastern Europe, the near East, Australasia and American stock, do not support Scigaj's claim that Hughes is pressing for a genetic link between Plath's German father and her aggressive nature. Nevertheless, Scigaj goes on to argue that Hughes's genetic determinism is even evident in his description of Plath's children:

${ }^{196}$ C.G. Jung, Collected Works, Vol.5, 'Symbols of Transformation', p. xxiv.

${ }^{197}$ The Nazis abolished the State of Prussia in 1934. 
Even in the final glimpses the determinism grinds on, with poems that note the Plath family features genetically inherited in his children - in Frieda's nimble fingers (194), so like her mother's "long, balletic" fingers (BL.15), and in Nick's eyes and facial features that are so like Otto's that his portrait could be Nick's (BL. 130, 182, 193). ${ }^{198}$

Scigaj's suggestions that Hughes is promoting the notion of genetic determinism through his descriptions of his and Plath's children, seems to be an over-reading. For example, the Birthday Letters poem 'Life After Death', which Scigaj refers to here, is an elegiac poem that, as the title suggests, celebrates Plath's children as part of her legacy: "What can I tell you that you do not know / Of the life after death?" the poem begins:

Your son's eyes, which had unsettled us

With your Slavic Asiatic

Epicanthic fold, but would become

So perfectly your eyes,

Became wet jewels,

The hardest substance of the purest pain

As I fed him in his white high chair.

Great hands of grief were wringing and wringing

His wet cloth of face. They wrung out his tears.

But his spoon-fed mouth betrayed you - it accepted

The spoon in my disembodied hand

That reached through from the life that had survived you.

In 'Life After Death', Hughes is describing the way Plath's suicide affected her family, a scene usually excluded from those versions of her story where it is she, rather than her husband and children, who is presented as a victim. At the same time, 'Life After Death' celebrates Plath's biological creativity as part of her legacy by offering an image of her children as part of the life that would survive her death.

198 'The Deterministic Ghost in the Machine of Birthday Letters'. 11-12. 
In this chapter I will be arguing, in contrast to critics such as Pollitt and Scigaj, that Hughes's treatment of Fate in Birthday Letters is not part of a strategy through which he attempts to avoid responsibility for his actions. Nor is it a means of burying the "particular" in the "mythic" as Wood has claimed. Although Birthday Letters describes events that take place in the objective outer world, Hughes's mythopoeia attempts to account for his and Plath's subjective experiences of these events. Throughout Birthday Letters, he looks back and, in making sense of his past, identifies significant events ('omens', 'portents', and 'crossroads') which foreshadow the story's "tragedy ending" (BL.74). The narrator's position in Birthday Letters is, in this respect, identical to that of the reader, and Hughes's treatment of Fate can be seen as a signal of the retrospective-revisioning that is part of his subjective search for truth and meaning. In attempting to make sense of his 'story' Hughes must look from the effect to the causes, and consequently the inevitability within the sequence is better understood as fait accompli rather than Fate.

However, Hughes is not only the narrator of the Birthday Letters story, he is also a character within the drama, and as a character the younger Hughes is unaware of this future. Consequently, there are two versions of Hughes in Birthday Letters: the younger Hughes involved in the drama, and the older Hughes who is looking on, like a director, selecting the scenes, positioning the cameras, and preparing for the scenes that will follow. Both Malcolm and Middlebrook have pointed out that Hughes split himself into two personae when writing about Plath in order to untangle himself from the story and retain his position as an impartial critic. These were Hughes the editor who commented upon her work, and "her husband" with the privileged, intimate knowledge of his wife. ${ }^{199}$ In Birthday Letters this division of self becomes a necessary narrative device. The older Hughes, the poet who is writing the Birthday Letters poems, looks back on his younger self as another distinct personality who acts blindly without the benefit of his future self's knowledge. The character, or hero, within the drama of the Birthday Letters poems is that distinct separate individual that Hughes referred to as "her husband" in his essays on

${ }^{199}$ In 'The Silent Woman' and in 'Her Husband'. 
Plath. In 'The Pan' these two versions of Hughes are dramatically represented in the same imaginative space:

When he stopped at last in the long main street

Of the small town, after that hundred

And ninety miles, the five-o'clock, September,

Brassy, low, wet Westcountry sun

Above the street's far end, and when

He had extracted his stiffness

From the car crammed with books, carrier bags

Of crockery, cutlery and baby things,

And crossed the tilting street in that strange town

To buy a pan to heat milk and babyfood

The moment they arrived

Hours ahead of the furniture

Into their stripped new house, in their strange new life,

He did not notice that the ironmonger's

Where he bought the pan had been closed

And empty for two years. And returning

With the little pan he did not notice

A man on the pavement staring at him,

His arm round a young woman who wore

A next-to-nothing long evening dress

Slashed to the hip, and a white, silk, open-work shawl

Round her naked shoulders, and leopard-claw ear-rings,

He did not recognise, nor did his wife

As he squeezed back weary beside her

Behind the wheel of the Morris Traveller,

That this man, barely two yards from them,

Staring at them so fixedly,

The man so infinitely more alive 
Than either of them there in the happy car

Was himself - knowing their whole future

And helpless to warn them.

(BL. 121)

Here, like Pollitt, the older Hughes looks back on his younger self and Plath "knowing their whole future" but is "helpless to warn them" in spite of his retrospective knowledge. The older Hughes narrating cannot intervene or change what has already happened. $\mathrm{He}$ can only look on and try to make sense of what has gone before. Conversely, the younger Hughes and Plath in 'The Pan' are blind to the future and so "did not notice" that the ironmongers "had been closed / And empty for two years", and similarly they did not notice the older Hughes standing and observing them from the future.

In 'You Hated Spain', we are also made aware of the double-exposure of Hughes's vision in Birthday Letters. His recollection of Plath on their honeymoon is tempered by his retrospective knowledge of her death in her near future:

I can see you, in moonlight,

Walking the empty wharf at Alicante

Like a soul waiting for the ferry,

A new soul, still not understanding,

Thinking it is still your honeymoon

In the happy world, with your whole life waiting,

Happy, and all your poems still to be found.

The notion of Plath being "like a soul waiting for the ferry" is a simile that suggests itself to the imagination of the older Hughes looking on at his now dead wife from her future. It indicates how the older Hughes's retrospective knowledge of the future necessarily transforms the significance and meaning of the drama of past events.

Hughes distinguishes his older self as narrator from himself as a character in the drama by portraying his younger self's ignorance and over-confidence, having not yet 
suffered misfortune. In 'Fulbright Scholars', for example, Hughes comments "At twentyfive I was dumbfounded afresh / By my ignorance of the simplest things" (BL.3). In 'Caryatids (1)' he describes himself as "Stupid with confidence" (BL.5), and when he and Plath set out on a boat fishing trip in 'Founders', they do so without planning or foresight: "our map, / [was] Somebody's optimistic assurance" (BL. 65). The character Hughes cannot see the impending tragedy that is so apparent to the older, wiser, Hughes. "Now I know, as I did not", the narrator comments in 'The Blue Flannel Suit'. Having read Plath's journals the older Hughes now knows that her fears about teaching were "terrors that had killed you once already" (BL.68) whereas the younger Hughes "had supposed / It was all OK. Your life / Was a liner I voyaged in” (BL. 67). ${ }^{200}$ This contrast between the older and younger Hughes in Birthday Letters can be seen as a Blakean double-exposure of 'innocence' and 'experience'.

Like Plath in her late poems, in Birthday Letters, Hughes is both narrator and tragic hero of the drama. Through the hero within the drama, readers become involved in the story, dramatically; we experience the unexpected shock of Plath's suicide, as Hughes did at the time. Through the older Hughes, narrating Birthday Letters, we watch the action from the future and interpret the significance of the events as we follow an inevitable path towards the already plotted tragic ending. In this sense Birthday Letters resembles a classical Greek tragedy. The poet's role is to retell the story that is already well-known to its audience in order to reveal the story's higher truth, its mythos.

Scigaj has said that "in Birthday Letters all the omens are bad omens."201 However, it is important to note that the omens are only assigned negative portentous values retrospectively by the narrator. The characters in the drama, on the other hand, ignore, overlook, or misunderstand the omens which have not yet acquired any significance. '55 Eltisley' begins with the Hugheses moving into their new address and inspecting the property:

\footnotetext{
${ }^{200}$ Perhaps an allusion to his description of the dance floor at the party in 'St Boltoph's', which is described as: "Like the tilting deck of the Titanic" (BL. 14). Again, this description of the St Boltoph's hall is tinged with the narrator's knowledge of the future.

201 'The Deterministic Ghost in the Machine of Birthday Letters'. 1.
} 


\section{When we first moved in there}

I looked for omens.

Vacated by a widow gathered to her family

All it told me was: 'Her life is over.'

She had left the last blood of her husband

Staining a pillow. Their whole story

Hung - a miasma - round that stain.

Here, the young Hughes deliberately looks for omens but the blood stain on a pillowcase tells him nothing more than he already knows about the previous tenants. To read 'omens' such as this as a signal that the characters' actions are driven by Fate is to overlook the way the omens in Birthday Letters only acquire value and significance retrospectively.

Throughout the sequence the young Hughes and Plath are shown repeatedly misinterpreting or ignoring omens that become significant to Hughes the narrator. In 'Caryatids (1)', for example, Hughes recalls that his first encounter with Plath was on the page, in reading her poem 'Three Caryatids Without a Portico'. The older Hughes, looking back, suggests that his younger self "missed" the portentous warning the poem contains:

I felt no interest. No stirring

Of omen. In those days I coerced

Oracular assurance

In my favour out of every sign.

So missed everything...

The portentous value attributed to these 'signs' or 'omens' is not contained within the sign itself, for in Birthday Letters meaning is arbitrary, subjective. The difference between the readings of the younger and older Hughes is not just the result of a matured 
outlook, but also a reflection of how, for Hughes, the significance and meaning of events changed following Plath's suicide and his subsequent discovery of the Ariel poems and her journals. Plath's writings are often the catalyst for Hughes's retrospection and for his subsequent reinterpretation of events. In 'The Lodger', for example, he recalls Plath's enthusiasm for beekeeping. However, this memory is now tainted by his reading of her 'bee poems' which he now connects to her preoccupation with her father:

When you wanted bees I never dreamed It meant your Daddy had come up out of the well.

In 'The Lodger', Hughes recalls that Plath had suggested they get a bee-hive and plant nine bean rows, presumably in tribute to Yeats's 'The Lake Isle of Innisfree'. Looking back, her suggestion becomes ominous in that it signals her preoccupation with her father's death. Hughes's retrospective understanding now rejects the connection of Plath's interest in a bee hive as relating to Yeats's poem and he suggests the nine bean rows he planted were simply a symptom of Hughes's 'sleepwalking':

\section{Meanwhile}

Who was using my heart,

Who positioned our bee-hive and planted,

With my unwitting hands, to amuse himself,

Nine bean rows? Who was this alien joker

Who had come to evict us?

Animals occasionally appear as omens or portents in Birthday Letters. In 'The Owl', for example, Hughes describes sucking "the throaty thin woe of a rabbit / Out of my wetted knuckle" to attract a tawny owl, attempting to make Nature perform for Plath's entertainment. The poem closes as the owl suddenly swoops "splaying its pinions" (BL. 33) at Hughes's face, as it mistakes him for a fence post. This incident is ominous in the sense that the Romans believed that the appearance of an owl was an omen of impending disaster, and believed that the hoot of an owl predicted a death. On 
the other hand, the appearance of an owl in ancient Greece was considered good fortune, and so, as with the other omens, the significance is dependent on the subjective interpretation of the observer. Like the older Hughes narrating, the reader knows the tragic ending of this story and consequently the ominous value of incidents such as these is provided by the reader.

The most unsettling of all the omens in Birthday Letters for the older Hughes retrospectively narrating the sequence, occurs in '9 Willow Street', in which the young Hughes, while walking on Boston Common, finds a bat lying in the grass beside a tree:

It took me a dizzy moment to make out

Something under the chestnuts, struggling

On a path of the Common, down near the Swan-boats.

What looked like a slug, black, soft, wrinkled,

Was wrestling, somehow, with the fallen

Brown, crumpled lobe of a chestnut leaf.

Suddenly, plainly, it was a bat.

A bat fallen out of its tree

Mid-afternoon. A sick bat? I stooped

Thinking I'd lift it again to tree-bark safety.

It reared up on its elbows and snarled at me,

A raving hyena, the size of a sparrow,

Its whole face peeled in a snarl, fangs tiny.

I tried to snatch it up by the shoulders

But it spun, like a fighter, behind its snarl.

A crowd collected, entertained to watch me

Fight a bat on Boston Common. Finally

I had to give it my finger.

Let the bite lock. Then, cradling it,

Gently lifted it and offered it up 
To the chestnut bark. It released me

And scuttled upwards backwards, face downwards,

A rearguard snarl, triumphant, contorted,

Vanishing up where it had come from.

At home I looked at the blood, and remembered:

American bats have rabies. How could Fate

Stage a scenario so symbolic

Without having secreted the tragedy ending

And the ironic death? It confirmed

The myth we had sleepwalked into: death.

This was the bat-light we were living in: death.

(BL.73-4)

The young Hughes involved in the drama is concerned only with the danger of contracting rabies from the bite of this apparently "sick" bat. However, to the older Hughes looking back, the incident can be seen as an elaborately staged scenario that prophesises his Fate. In '9 Willow Street' Hughes fights with this aggressive "American" bat he is attempting to assist. Their struggle becomes public when a crowd of onlookers gather around "entertained" to watch the spectacle as he sacrifices a little blood to appease the bat he attempts to assist before it "vanishes". ${ }^{202}$ To the older Hughes, this incident provides a symbolic dramatisation of his marriage and posthumous relationship with Plath's writings. The symbol of the bat is particularly apt for Hughes in the way it corresponds with (and reverses) Plath's description of himself as "the vampire" who "drank [her] blood for ... Seven years" (SPC.224) in 'Daddy'. Hughes's sensitivity to Plath's portrayal of him in this poem is likely to have prompted his children's book Ffangs the Vampire Bat, in which the hero complains:

'But I'm not really a vampire.

I can't stand the sight of blood, let alone the taste of it.

\footnotetext{
${ }^{202}$ We will be looking at the nature of Hughes's imaginative blood sacrifice in Birthday Letters to Plath in chapter 7 'The Shamanic Journey'.
} 
I'm a failed vampire.

I don't want to be a vampire.

I want to get back to the world and become human. ${ }^{203}$

Furthermore, not all of the omens in Birthday Letters are bad omens. The only bad omens in Birthday Letters are those identified by the narrator retrospectively. However, the characters within the drama who do not have the advantage of a retrospective perspective often interpret events as positive. At first glance, the title of the poem, 'Fate Playing', seems to imply that Fate plays with the characters in the drama. However, the poem itself suggests that it is in fact the characters that are 'playing' at Fate in assigning significance to incidents and events. In 'Fate Playing' Hughes recalls how his arrangements to meet Plath in London become confused and almost fail. While Hughes is travelling to London by train, Plath awaits him at a bus station. When he does not arrive, Plath, being new to London, becomes upset and frightened. It is only by good fortune that someone suggests she try the train station. Hughes, meanwhile, is "unperturbed" and unaware of Plath's drama until he arrives at Kings Cross station and, by fortuitous chance, at that moment, she also arrives on the train station platform:

When I got off the train, expecting to find you

Somewhere down at the root of the platform,

I saw that surge and agitation, a figure

Breasting the flow of released passengers,

Then your molten face, your molten eyes

And your exclamations, your flinging arms

Your scattering tears

As if I had come back from the dead

Against every possibility, against

Every negative but your own prayer

To your own gods. There I knew what it was

To be a miracle.

${ }^{203}$ Hughes, Ted. Ffangs the Vampire Bat and the Kiss of Truth. London: Faber and Faber, 1986. 30. 
Plath's reaction seems disproportionate to the younger Hughes. However, the older Hughes, who knows from Plath's writings how she conflated him with her father, understands that, because "precedents tripped [her] expectations" (BL.31), she expected him to abandon her. Hughes's arrival on the platform becomes then, in Plath's subjective interpretation of events, an omen that portends their future good fortune:

Well it was a wonder

That my train was not earlier, even much earlier

That it pulled in, late, the very moment

You irrupted onto the platform. It was

Natural and miraculous and an omen

Confirming everything

You wanted confirmed.

(BL. 32)

There are two meanings attached to this event: To the young Plath, Hughes's appearance on the platform becomes "an omen / Confirming everything". However, to the older Hughes looking back on Plath's disproportionate reaction, this incident confirms Plath's fear of being abandoned by her father-god-lover. Had the future turned out differently, the significance of this incident would have been different to the older Hughes. Similarly, had Plath's interpretation of her history been different, then this event might have appeared less significant to her. In 'Fate Playing' Hughes suggests that Fate is in fact a game that we play in translating events into meaningful patterns, assigning value to certain events to explain our histories and imagine our future. This incident also serves as an example of the way that values are attributed to signs (and 'omens') arbitrarily and retrospectively in Birthday Letters. The omens are only ominous because we, like Hughes, imbue events in our lives with meaning and significance.

Another example of the characters in Birthday Letters misreading signs is offered in '9 Willow Street', when Hughes and Plath choose an address that suggests poetic inspiration: 
Willow Street, poetical address.

Number nine, even better. It confirmed

We had to have it. We got it.

A tower of the Muses.

Hughes and Plath believe the address itself is a sign that guarantees successful inspiration for their writing. However, despite their positive reading of this omen, they find they are unable to write at the address:

I covered the windows with brown paper, Pushed ear-plugs in on my inflamed nerves And sank. In the other room, Perched up in the glare, on the cliff edge, You hammered your new Hermes, Your Panic Bird chipping at the old egg, While I rolled in my sack, with my lumber, Along the bottom of the Charles. We huddled. Me In my black sack striking sulphur matches To find the eyes of Jung's nigredo. You In a paralysis of terror-flutters I hardly understood.

All that the house at 9 Willow Street inspires is confusion, disappointment and fear. However, to the older Hughes narrating, this period of their life becomes an early revelation of their incompatible temperaments, a portent of the way their different needs and temperaments would become injurious to one-another:

\section{Alone}

Either of us may have met with a life.

Siamese-twinned, each of us festering 
4 Fate

A unique soul-sepsis for the other,

Each of us was the stake

Impaling the other. ${ }^{204}$

If Hughes is attempting to suggest a deterministic universe in Birthday Letters, then the omens which are misread, or which turn out not to be omens, or which have multiple significances, undermine his project. It would be more accurate to see Hughes's use of Fate and portents in Birthday Letters as a general commentary on how the values we assign to events are provisional and evolve as our stories evolve.

Hughes repeatedly advertises the subjectivity of his interpretation of events in the Birthday Letters story. He also foregrounds Plath's subjectivity by translating the outer material world through the mythic lens of her poems. The characters in the Birthday Letters story are, therefore, performing roles in Plath's drama and although they are in control of, and responsible for their own actions, these actions are interpreted through her subjective mythic drama. Lacking hindsight, the characters do not yet know they have been cast in the roles they will perform retrospectively after the tragic ending, or that this drama is indeed a tragedy. Hughes appears to be appealing for understanding, rather than avoiding responsibility, in making a distinction between the significance of his actions at the time of the drama and the way his actions will be interpreted in the future.

In 'Visit', Hughes recalls how he and Lucas Myers threw dirt at a bedroom window they believed belonged to Plath:

Drunk, he was certain it was yours.

Half as drunk, I did not know he was wrong.

Nor did I know I was being auditioned

For the male lead in your drama,

Miming through the first easy movements

As if with eyes closed, feeling for the role.

${ }^{204}$ An allusion to Plath's 'Daddy': “There's a stake in your fat black heart" (SPC.224). 
As if a puppet were being tried on its strings,

Or a dead frog's legs touched by electrodes.

As narrator, Hughes describes his younger self being "auditioned" for the role he will play in the drama. As he throws clods at the window, the young Hughes does not yet know that his actions are being recorded in Plath's writings, that his actions are being consumed by the mythos she is creating. It is only the older Hughes, reading the dramatic interpretation of his actions in Plath's journals, who learns the significance of his actions:

Ten years after your death

I meet on a page of your journal, as never before,

The shock of your joy

When you heard of that. Then the shock

Of your prayers. And under those prayers your panic

That prayers might not create the miracle,

Then, under the panic, the nightmare

That came rolling to crush you:

Your alternative - the unthinkable

Old despair and the new agony

Melting into one familiar hell.

The drama within Birthday Letters is largely directed by Hughes's readings of Plath's writings. The narrator's role is retrospectively to identify the meaning and significance of each scene. As we will see in the next chapter, drawing on Plath's 'myth', the older Hughes sees himself cast in the role of the tanist in the Goddess myth, as the temporary replacement for the dead sacred king (Otto Plath). As the tanist, Hughes will rule as the Goddess's lover until he is sacrificed, to ensure her rebirth when he is replaced by the resurrected Otto. Hughes believed that Plath's obsession with this mythic schema was not just a literary frame for her writings but helped her to make sense of her personal history and distil hope for the future. In Birthday Letters, this controlling myth means that Plath's (and Hughes's) fate can be read very clearly from a retrospective 
reading of her poems. In 'Horoscope', Hughes recalls Plath's interest in astrology in order to see what the future held:

You wanted to study

Your stars - the guards

Of your prison yard, their zodiac.

He then goes on to suggest that Plath had no need to study astrology, "no need to calculate / Degrees for your ascendant disruptor / in Aries" (BL.64) because her poetry contained a more accurate prediction of her Fate than any horoscope ever could:
You only had to look
Into the nearest face of a metaphor
Picked out of your wardrobe or off your plate
Or out of the sun or the moon or the yew tree
To see your father, your mother, and me
Bringing you your whole Fate.

This Fate, according to the story of Birthday Letters, is contained in the cyclical pattern of death and rebirth in Plath's myth. This mythic schema predicts her own death and rebirth in the posthumous voice of her poems. As a character in Plath's poems, Hughes must perpetually perform his role as her ritual scapegoat until he can free himself from the drama. Plath's writings have the power imaginatively to transform reality, and in 'Visit', as he reads her journals, Hughes finds himself back in the past, in the imaginative reality of her words:

I look up - as if to meet your voice

With all its urgent future

That has burst in on me. Then look back

At the book of the printed words.

You are ten years dead. It is only a story. 
In looking back on his life through Plath's writings, Hughes sees his past through the lens of "the myth [he and Plath] sleepwalked into" (BL.74). As Middlebrook has said Birthday Letters is the story of how "Ted and Sylvia stumbled into each other's power to transform mere human beings in a myth." 205 Because Hughes featured so prominently in Plath's writings, he is particularly susceptible to the transformative powers of her writing and is forced to take the "male lead in [her] drama" (BL. 7). In 'Suttee', Hughes describes how this "new myth" consumes his and Plath's identities as Plath is resurrected and reborn phoenix-like in the voice of her poems, as she predicts in 'Lady Lazarus', to avenge herself and punish Hughes for his betrayal, like Orpheus, or Actaeon, who are dismembered by the Maenads and hounds respectively for offending the Goddess.

As the older Hughes looks on, awaiting the tragedy ending, the young characters, Hughes, and Plath, are more optimistic. They still do not know what roles they have been allotted in life. As Hughes says in 'Caryatids (2)', the younger Hughes and his friends appeared to have "Time in plenty / To test every role - for laughs, / for the experiment" (BL.5). Plath, we later learn, imagined Hughes and herself in the role of the lovers in Shakespeare's The Tempest. In 'Setebos', Hughes addresses her:

Who could play Miranda?

Only you. Ferdinand - only me.

And it was like that, yes, it was like that.

I never questioned. Your mother

played Prospero, flying her magic in

$\begin{array}{ll}\text { To stage the Masque, and bless the marriage... } & \text { (BL. 132) } \\ \end{array}$

To the younger Hughes and Plath, The Tempest ensures a happy ending to the drama and in 'A Pink Wool Knitted Dress', which describes their wedding day, Plath evokes

\footnotetext{
205 'Her Husband'. 280

${ }^{206}$ The Tempest also draws a parallel, of course, between 'Ariel' the spirit of Shakespeare's play, and Ariel the book of poems in which Plath dramatises the unpleasant side of their relationship.
} 
Caliban's dream to describe her happiness: "You said you saw the heavens open / And show riches, ready to drop on us" (BL.35). However, when their marriage fails, it is no longer clear what roles they are performing in the play, or, indeed, what play they are in:

Then the script overtook us. Caliban

Reverted to type. I heard

The bellow in your voice

That made my nape-hair prickle when you sang 207

How you were freed from the Elm. I lay

In the labyrinth of a cowslip

Without a clue... Which play

Were we in?

In the final lines of 'Setebos', the 'love story' of The Tempest has become another kind of drama. It is now, perhaps, as Jo Gill has pointed out, like Ariel "a play about deception and revelation, about tyranny and enslavement - a drama in which family bonds are confused or betrayed and here the magical power of language is used to subjugate and silence as well as to create and heal."208 At the close of 'Setebos', Hughes discovers that his and Plath's reading of The Tempest no longer explains the drama and he must search again for meaning.

Confronted with the posthumous voice of Plath's poems, Hughes returns to The Tempest. In Shakespeare's play, the spirit Ariel was trapped in a pine by the witch Sycorax until it is freed by the magician Prospero. In Birthday Letters, as in Hughes's critical writings, the Ariel-voice, which is the voice of Plath's true self, is released from the elm tree in her poem 'Elm'. Hughes reiterates this reading again in 'The Table', in which Hughes recalls building Plath "a solid writing table / That would last a lifetime"

\footnotetext{
${ }^{207}$ Describing the White Goddess, Robert Graves comments: "The reason why the hairs stand on end, the eyes water, the throat is constricted, the skin crawls and a shiver runs down the spine when one writes or reads a true poem is that a true poem is necessarily an invocation of the White Goddess, or Muse, the Mother of All Living, the ancient power of fright and lust - the female spider or the queen-bee whose embrace is death." Graves, Robert. The White Goddess. London: Faber and Faber. 1948. 24.

${ }^{208}$ Gill, Jo. 'The Colossus and Crossing the Water'. The Cambridge Companion to Sylvia Plath. Cambridge: England, 2006. 96.
} 
from an "elm plank [that has been ] / Rough cut for coffin timber" (BL. 138).

Retrospectively, the older Hughes sees this table as the "elm door" of her father's coffin, although the younger Hughes "did not / Know I had made and fitted a door / Opening downwards into your Daddy's grave" (BL.138). The dark irony in the description of this "coffin timber" table that would "last a lifetime" is supplied by the older Hughes, who looks back on his former actions helplessly at his younger self who "sleepwalked / Like an actor with his script" (BL. 139). Hughes's fatalism, here, can be seen as a narrative device that allows Hughes to distinguish the meaning of his younger self's actions at the time from the significance that was attached to his actions after Plath's death, and the publication of her late poems. Through the narrator's retrospective re-visioning, Hughes demonstrates how Plath's readers looking back and interpret his actions in terms of their effect.

However, Hughes is not only contending with his readers' subjective judgements of events, he is also highlighting the subjectivity of Plath's drama that has, for many, defined his actions. In this sense, Hughes's use of Fate is the story of his entanglement with the controlling agency of Plath's mythos - this is the story that would define him, as Pollitt has said, as "the most notorious literary spouse in history". ${ }^{209}$ In 'The God', Hughes suggests that:

The story that has to be told Is the writer's God, who calls Out of sleep, inaudibly: 'Write.'

According to Hughes, the story that Plath has to write is the story of her true self's imprisonment following her father's death when she began to live an inauthentic existence. In the drama of her poems her authentic existence ends when her false self is killed so that her buried true self can be reborn. As we will see in the next chapter, the Goddess myth, or what Graves calls "The Theme", helped Plath translate the most significant incidents in her history into a positive narrative of rebirth. According to

209 'Peering into the Bell Jar'. 
Hughes's reading of Plath, she saw her suicide attempt of 1953, which she described as an attempt to get back to her father, as the 'death' that led to the subsequent 'rebirth' of her electro-convulsive treatment.

Hughes's adoption of Plath's mythic theme as a controlling agent of her Fate in Birthday Letters is not a way of attempting to avoid responsibility for Plath's suicide, but a way of explaining how his actions, read through Plath's subjective mythopoeia, led inevitably to her death. By introducing Plath to Robert Graves, by encouraging Plath in her efforts in her poetry, Hughes is midwife to this rebirth. Furthermore, in embarking on his extramarital affair he unwittingly performs the role of the surrogate god-father abandoning her, and reconnects Plath with the unresolved grief she experienced as an eight-year-old child when her father died. As he later learns when he reads Ariel, in Plath's subjective vision, Hughes's actions confirm his role as the scapegoat to be killed and ensure her rebirth.

In 'Setebos', Hughes describes the aftermath of Plath's suicide, after Ariel has been released from the elm. The younger Hughes has become disorientated by the unexpected tragic turn of the drama:

I woke up on the empty stage with the props ${ }^{210}$

The paltry painted masks. And the script

Ripped up and scattered, its code scrambled,

Like the blades and slivers

Of a shattered mirror. ${ }^{211}$

In lieu of a 'story' to explain the tragedy, Hughes must look to the scrambled code in Plath's poems. These appear to the younger Hughes "like the blades and slivers of a

\footnotetext{
${ }^{210}$ In 'Electra on Azalea Path' Plath describes her realization of her father's death in similar terms - "The day I woke, I woke on Churchyard hill" (SPC.117).

${ }^{211}$ Perhaps a reference to the folk belief that breaking a mirror brings seven years bad luck. Hughes' and Plath's marriage lasted seven years.
} 
shattered mirror" in which he sees a distorted reflection of their story. In a 1995 essay, Hughes describes Plath's poem 'Mirror' as prophesising her Fate:

The mirror is her clairvoyant self-understanding. It is the eye of 'a little god' and incapable of knowing or telling anything but the perfect truth. Bending over it, the author sees her destiny, which is to have drowned in herself a young girl (her 'first death' and the death of her father) and to confront a homicidal old woman who will rise out of herself 'like a terrible fish' to kill her. ${ }^{212}$

If Hughes's fatalism in Birthday Letters is a way for him to exonerate himself of responsibility, this does not explain why the other characters in the drama are equally blind to their future. The characters in the drama exist in a "bat-light" (BL. 74) unwittingly performing their roles. This 'automatism' should not be confused with a defence against liability. In 'Dreamers', we learn that, in addition to Hughes and Plath, Assia Wevill is also sleepwalking: "None of us could wake up" (BL.158). This is because the characters' innocence is emphasised by the narrator's retrospective knowledge

Plath is as helpless as the other characters in the drama because her myth controls her perceptions and apprehension of reality. When the rebirth motif of her myth is dominant, Hughes connects her with the Goddess in her creative aspect. In 'Remission', for example, Hughes suggests Plath's biological creativity emphasises her connection with the life-affirming aspect of the Goddess and offers her an escape route out of her psychological predicament:

A fragile cutting, tamped into earth

You took root, you flourished only

In becoming fruitful - in getting pregnant

In the oceanic submissions

Of giving birth. That was the you

212 'Winter Pollen: U.S. edition'. 471. 
You loved and wanted to live with.

(...)

That was the you you shared with the wild earth.

It was your membership

Of a sorority of petals and creatures

Whose masonic signs are beauty and nectar

In the love-land, the Paradise

Your suicide had tried to drag you from.

And it was the you that escaped death

In the little woven vessel

On that most earthly river

Of that Paradise.

Adopting Plath's mythopoeic explanation of her personal history, Hughes explains how Plath understood her suicide attempt of 1953 and subsequent electro-convulsive treatment as the ritual 'death' and 'rebirth' she encountered in the Goddess myth. In becoming pregnant, Plath identifies with the Goddess in her life-affirming aspect, as a vessel of the magical creative powers of nature. Hughes revisits this theme in the poem 'Isis', which records the birth of Frieda, and again depicts Plath's identification with this positive aspect of the Goddess:

Our Black Isis had stepped off the wall ${ }^{213}$

Shaking her sistrum -

Polymorphus Daemon,

Magnae Deorum Matris - with the moon

Between her hip-bones and crowned with ears of corn.

The great goddess in person

${ }^{213}$ A photograph of the picture (see Appendix 3) of "Isidis: Magnae Deorum Matris" ("great mother of the gods") that hung in Hughes's and Plath's home appears in the photograph section of 'Bitter Fame'. 
Had put on your body, waxing full

Using your strainings

Like a surgical glove, to create with,

Like a soft mask to triumph and be grotesque in

On the bed of birth.

It was not Death

Weeping in you then, when you lay among the bloody cloths

Holding what had come out of you to cry.

It was not poetic death

Lifted you from the blood and set you

Straightaway lurching - exultant -

To the phone, to announce to the world

What Life had made of you,

Your whole body borrowed

By immortality and its promise,

Your arms filled with what had never died, never known Death.

(BL.112)

Despite these temporary remissions, throughout Birthday Letters Hughes suggests that in her struggle with her writings, Plath often felt as though she had not actually been re-born, as though she were still in a period of stasis, a period in which her true self remained in gestation. In her darker moods Plath becomes obsessed with the death motif of the Goddess myth which she sees as the necessary ritual prelude to the rebirth she desperately awaited in her psychological life and in her writings.

Plath's journals indicate that she believed that only by facing and finally conquering the buried grief of her true self, the grief that had led to her first 'death', could she be reborn. In 'The Shot' Hughes dramatises her preoccupation with her father's death as the catastrophic event of her childhood that led inevitably to her selfdestruction: 
Your Daddy had been aiming you at God

When his death touched the trigger.

In that flash

You saw your whole life. You ricocheted

The length of your Alpha career

With the fury

Of a high-velocity bullet

That cannot shed one foot-pound

Of kinetic energy.

Plath's father, Otto, haunts many poems in Birthday Letters, such as 'The Minotaur', 'The Shot', 'The Table', 'Fairy Tale', 'Being Christlike', and 'The Bee God'. Rather than interpreting this haunting literally, as evidence of an external agency controlling the lives of Hughes and Plath in Birthday Letters, we should understand it as dramatic representation of Plath's imaginative life. The anthropomorphic figures of Life and Death that appear in 'Isis' should be understood in the same way. 'Isis' describes the day that Hughes and Plath set out on a road trip across America. Plath was pregnant with their daughter Frieda, and so their 'lightest bit of luggage' is the goddess Isis, the Egyptian version of the Goddess in her positive aspect, whose presence, in turn, explains Plath's positive outlook that day:

The morning we set out to drive around America

She started with us. She was our lightest

Bit of luggage. And you had dealt with Death.

You had come to an agreement finally:

He could keep your Daddy and you could have a child.

Hughes recalls that on this day Plath seemed cured of her preoccupation with death; perhaps, he speculates retrospectively, because of the new life growing within her: 
Finally you had stripped the death-dress off,

Burned it on Daddy's grave.

Did it so resolutely, made

Such successful magic of it, Life

Was attracted and swerved down -

Unlikely, like a wild dove, to land on your head.

Day of America's Independence

You set out. And I, not Death,

Drove the car.

(BL.111)

However, the older Hughes, looking back, knows that Death was not vanquished and had only suffered a temporary setback. The older Hughes retrospectively knows that Death has not quit permanently but is only hiding somewhere awaiting the return of Plath's attentions:

Was Death, too, part of our luggage?

Unemployed for a while, fellow traveller?

Did he ride on the car top, on the bonnet?

Did he meet us now and again on the road,

Smiling in a café, at a gas station?

Stowaway in our ice-box?

Did he run in the wheel's shadow?

Or did he sulk in your papers, back in your bedroom,

Waiting for your habits

To come back and remember him?

Like Plath's father, the anthropomorphic figure of Death in Birthday Letters is not actually manifest in the material world extending control over events. He depends on Plath's imagination to influence the drama. 
In Plath's poems, Death is usually depicted as female and in Birthday Letters, Hughes suggests that Plath's image of the Goddess in her Death Aspect was drawn from her subjective perceptions of Assia Wevill, whom she imagined as her 'Other', her 'rival'. In 'Dreamers' Hughes presents Assia through Plath's subjective gaze:

She fascinated you. Her eyes caressed you, Melting a weeping glitter at you.

Her German the dark undercurrent In her Kensington jeweller's elocution Was your ancestral Black Forest whisper Edged with a greasy, death-camp, soot-softness. When she suddenly rounded her eyeballs, Popped them, strangled, she shocked you. It was her mock surprise.

But you saw hanged women choke, dumb, through her, And when she listened, watching you, through smoke, Her black-ringed grey iris, slightly unnatural, Was Black Forest wolf, a witch's daughter Out of Grimm.

Hughes describes Wevill as fascinating Plath at the same time as horrifying her and making her fearful. As we saw in chapter 2, Plath's subjective encounter with Wevill appears to be a description of an encounter with the Goddess in her death aspect. In The White Goddess, Graves gives a description of her:

The Goddess is a lovely, slender woman with a hooked nose, deathly pale face, lips red as rowan-berries, startlingly blue eyes and long flaxen hair; she will suddenly transform herself into sow, mare, bitch, vixen, she-ass, weasel, serpent, owl, she-wolf, tigress, mermaid or loathsome hag. Her names and titles are innumerable. In ghost stories she often figures as 'The White Lady', and in ancient religions, from the British Isles to the Caucasus, as the 'White Goddess'. 
The reason one's hairs stand on end, the eyes water, the throat is constricted, the skin crawls and a shiver runs down the spine when one writes or reads a true poem is that a true poem is necessarily an invocation of the White Goddess, the Muse, the Mother of All Living, the ancient power of fright and lust - the female spider or the queen-bee whose embrace is death. ${ }^{214}$

In Assia, Plath recognises the destructive 'death' aspect of the Goddess that she attempted to suppress in her association with the Goddess's creative 'rebirth' aspect. Hughes and Plath knew that Assia was rumoured to have had abortions and her childlessness both fascinates and horrifies Plath. For her, an encounter with Assia was like an encounter with that suppressed destructive aspect of herself that surfaced in her poetry and looked down at the drama indifferently in the symbol of the moon. In 'Dreamers', Hughes portrays Plath's subjective impressions he finds in her writings and describes Plath asking herself: "Who was this Lilith of abortions / Touching the hair of your children / With tiger-painted nails?" (BL.157). ${ }^{215}$ Hughes's adoption of Plath's subjective vision here suggests that the threat Assia embodies is not just in the material world where Assia is a threat as a seductress, but a threat in the way she corresponds to the self-destructive aspect of Plath's psyche that had led to her first suicide attempt in 1953. This is why Hughes suggests that the Assia of Birthday Letters "was helpless too" in becoming a part of their drama: "The Fable she carried / Requisitioned you and me and her, / Puppets for its performance" (BL.157).

Wevill is generally considered to be the inspiration behind poems by Plath such as 'Childless Woman', which associates the Moon Goddess in her death aspect (demanding a blood sacrifice) with menstruation and depicts her as a symbol of death and infertility: "The womb / Rattles its pod, the moon / Discharges itself from the tree with nowhere to go" (SPC.259). Wevill is also likely to be the inspiration for 'The Munich Mannequins' in which a childless woman's ovum, a symbol of her rejection of her biological creativity and new life is translated into the image of the moon:

\footnotetext{
214 'The White Goddess'. 24.

${ }^{215}$ Lilith was a Mesopotamian version of the Goddess in her negative aspect, a demon seductress who was unable to have children and was said to have no milk in her breasts.
} 
Perfection is terrible, it cannot have children.

Cold as snow breath, it tamps the womb

Where the yew trees blow like hydras,

The tree of life and the tree of life

Unloosing their moons, month after month, to no purpose

The blood flood is the flood of love,

The absolute sacrifice

It means: no more idols than me,

Me and you.

(SPC.262-3)

In 'The Fearful', Plath describes another unnamed woman's childlessness as vain and unnatural. Again, in 'The Fearful', childlessness is presented as a rejection of the body's creative magic, as a refusal of immortality, a pact with death:

She hates

The thought of a baby -

Stealer of cells, stealer of beauty -

She would rather be dead than fat,

Dead and perfect, like Nefertit

(SPC.256)

The 'dead and perfect' woman depicted in this poem anticipates the central image in what may have been Plath's final poem, 'Edge'. If the central image of 'Edge' is, as commonly interpreted, a self-projection of Plath, then we can read this as the final act of her drama in which the heroine refuses the rebirth celebrated in many of her earlier Ariel 
4 Fate

poems and submits to the death of her mythos, under the watchful gaze of the indifferent moon goddess. 


\section{The Plath Myth}

As Susan Van Dyne has pointed out, because the poems and novel that made Plath's name have reached most readers as posthumous events "her work has inevitably been read through the irrevocable, ineradicable and finally enigmatic fact of [her] suicide."216 The earliest reviewers of Ariel read Plath's poems as confessional pieces. Nevertheless, critics such as A.E. Dyson in the Critical Quarterly noticed the poems' mythopoeic quality:

Sylvia Plath's last poems, written just before her death in 1963, have impressed themselves on many readers with the force of myth. ${ }^{217}$

Lowell also noted the mythopoeic quality of the poems in his foreword to the American edition of Ariel, suggesting that through the mythic personae of Ariel, Plath's historical identity is transformed into "something imaginary":

In these poems, written in the last months of her life and often rushed out at the rate of two or three a day, Sylvia Plath becomes herself, becomes something imaginary, newly, wildly and subtly created - not a person at all, or a woman, certainly not another "poetess", but one of those super-real, hypnotic, great classical heroines... The voice is now coolly amused, witty, now sour, now fanciful, girlish, charming, now sinking to the strident rasp of the vampire - a Dido, Phaedra, or Medea... ${ }^{218}$

Lowell pointed out that, in Ariel, Plath's historical personality serves the mythic personae of her poems so that, rather than being confessional, the poems are an enabling fiction through which the poet rewrites the self. For critics such as Lowell, Plath's suicide

\footnotetext{
${ }^{216}$ Van Dyne, Susan R. 'The problem of biography'. In: Gill, Jo. Ed. The Cambridge Companion to Sylvia Plath. Cambridge: Cambridge University Press, 2006. 3.

${ }^{217}$ Dyson, A. E. 'Necessity and Freedom: The Poetry of Robert Lowell, Sylvia Plath, and Anne Sexton' Critical Quarterly. VII No. 1. 1965

${ }^{218}$ Lowell, Robert. 'Foreword': Plath, Sylvia. Ariel. New York: Harper and Row, 1965. vii.
} 
seemed a final act of self-sacrifice to the demands of this mythology by which the historical active life of the author is offered to the poetic drama of death and rebirth. As Elizabeth Hardwick put it: "When the curtain goes down, it is her own dead body there on the stage, sacrificed to her plot." 219

Over the years, this correlation of myth and biography in Plath's poems has presented ongoing difficulties for biographers and critics alike. It seems paradoxical that Hughes, having spent most of his adult life struggling to untangle his and Plath's historical life from the drama in Plath's poems, should provide an account of their lives through the same mythopoeia in Birthday Letters. However, when we look at Hughes's essays over the years we find his fusion of Plath's historical identity and the speakers in her poems has been consistent. In his 1965 essay 'Sylvia Plath' for the Poetry Book Society, Hughes writes: "Ariel is not easy poetry to criticize. It is not much like any other poetry. It is her. Everything she ever did was like this, and this is just like her - but permanent." 220 If, as Hughes asserts, Plath's Ariel "is her", then the question arises as to why her poems should not be considered alongside other 'confessional' poets such as Lowell and Anne Sexton? The answer lies in Hughes's understanding Plath's poetry as the dramatic resolution, and record, of a psychological drama: as an imaginary ritual through which she re-writes and heals herself. For Hughes, Plath's poems all tell the story of her progress in resolving the "task she faced in herself". The poems are a record of a battle in which the combatants are opposed aspects of herself. Hughes is not attempting to pathologise Plath. He believed that such 'crises' were common and were a natural means for the psyche to heal itself. Indeed, Hughes believed that this was the purpose of all true art. As we have seen, Hughes believed all great works of art, like myths, contain the symbols and drama that enable the participant (writer or reader) to restore balance to the needs of the inner and outer worlds.

\footnotetext{
${ }^{219}$ Hardwick, Elizabeth. Seduction and Betrayal. London: Weidenfeld \& Nicholson, 1974. 107.

220 'Winter Pollen' 162.
} 
Hughes points out that Plath's earlier writings were written "very slowly, [with a] Thesaurus open on her knee". ${ }^{221}$ However, her Ariel poems were composed "at top speed, as one might write an urgent letter", 222 and she often wrote on or completed up to three poems a day. According to Hughes, Plath was inspired to write the Ariel poems because of an inner compulsion to heal herself. In his introduction to her Journals, he argues that Plath was incapable of writing about the objective world because the demands of her inner world demanded her attention whenever she wrote:

One would like to emphasize ... the weird autonomy of what was going on in there. It gave the impression of being ... a womb, an almost biological process and just as much beyond her manipulative interference. And like a pregnancy selfish with her resources... that magnetic inner process seemed to engross all her attention, one way or another. And in her poems and stories, throughout this period, she felt her creative dependence on that same process as subjugation to a tyrant... The hidden workshop, the tangle of roots, the crucible, controlled everything. Everything became another image of itself, another lens into itself. And whatever it could not use in this way, to objectify some disclosure of itself, did not get onto the page at all... ${ }^{223}$

Plath commented on this unremitting inward gaze of her writing in her journals: "I shall perish if I can write about no-one but myself. Where is my old bawdy vigour and interest in the world around me? I am not meant for this monastery living." 224

The Journals suggest that, in Plath's sessions with Ruth Beuscher, she was encouraged to connect her father's death in childhood with her later breakdown and suicide attempt of 1953. As Hughes explains in the introduction:

\footnotetext{
221 'The Art of Sylvia Plath'. 188.

222 'The Art of Sylvia Plath'. 193.

223 'Winter Pollen'. 180-181.

224 'The Journals'. 522. [4 November 1959]
} 
She would describe her suicide attempt as a bid to get back to her father, and one can imagine that in her case this was a routine reconstruction from a psychoanalytical point of view. But she made much of it, and it played an increasingly dominant role in her recovery and in what her poetry was able to become. $^{225}$

The Journals also suggest that, in her sessions with Beuscher, Plath was encouraged to see her personal history in mythic terms, as she comments in one 1959 entry:

As usual after an hour with RB, digging, felt I'd been watching or participating in a Greek play: a cleansing and an exhaustion. I wish I could keep the revelations, such as they are, fresh in mind ... A great, stark, bloody play acting itself out over and over again behind the sunny façade of our daily rituals, birth, marriage, death, behind parents and schools and beds and tables of food: the dark, cruel, murderous shades, the demon-animals, the Hungers. ${ }^{226}$

Plath's description of her self-mythologizing as being a process of "cleansing" connects the fusion of mythology and biography in her poems with Hughes's notion of art as an imaginative ritual form of healing. To the ancient Greeks, the verb katharein, from which the word 'catharsis' comes, meant to 'cleanse' or to 'purge' and was used in relation to mystical religious rituals. Over the years, in his essays and introductions, Hughes argued that Plath's poems should be seen as a kind of imaginative ritual of healing in which Plath confronts, defeats, and is finally overwhelmed by, "the bogies of her life". 227

According to Hughes, Plath's poems should not be understood as occasional pieces responding to incidents and events in her everyday life. On the contrary, the incidents and events that are recorded in the poems are subject to and constellate around a single mythic drama:

\footnotetext{
225 'Winter Pollen'. 180.

226 'The Journals'. 455-6.

227 'Winter Pollen'. 188.
} 
Most readers will perceive pretty readily the single centre of power and light which her poems all share... The poems are chapters in a mythology where the plot, seen as a whole and in retrospect, is strong and clear - even if the origins of it and the dramatis personae are at bottom enigmatic. ${ }^{228}$

As we have seen, in a 1966 letter to Plath's mother Aurelia, Hughes said that Plath should not be considered alongside confessional poets such as Lowell. If Lowell is a "fine doctor", he suggested, then Plath is "a miracle healer" 229 Hughes described poets such as Lowell and Sexton as part of the "self therapy school" and suggested that Plath is "a mystical poet of an altogether higher - in fact of the very highest tradition". This is because the healing properties of Plath's poems were not self-referential but were the archetypal symbols and drama of myth, which allowed her readers to participate in the same imaginative healing ritual.

In the same 1966 letter to Aurelia, Hughes said that he wanted "to avoid seeming to set myself up as the high priest of [Plath's] mysteries" because of his role in her life. Hughes's early sensitivity to any perception that he was attempting to control the interpretation of Plath's poems meant that his critical writings about her are largely confined to his introductions to her books (apart from a few short occasional pieces). In these writings, his understanding of Plath as a 'visionary' poet remained consistent. However, his reluctance to direct interpretations of Plath's work means that, for an indepth analysis of his ideas, our best source is Kroll's Chapters in a Mythology, which closely relates to Hughes's reading; indeed the book's title is taken from Hughes's description of Plath's poems in the quotation above.

In Chapters in a Mythology, Kroll complains about the biographical approach of much Plath scholarship, which she sees as having become "entangled in a fascination with [Plath's] suicide and broken marriage". This kind of approach, she points out, treats

\footnotetext{
228 'The Art of Sylvia Plath'. 187.

229 'Emory'. Ted Hughes Collection. Box 55 FF2. [Letter from Ted Hughes to Aurelia Plath 1966].
} 
Plath's poems as "bloodstains at the site of a murder, [or as] residues of real events" 230 and does not enquire into the nature of Plath's 'genius', which is simply taken for granted. Kroll suggests that instead we should confront Plath's poems on their own terms as "the articulation of a mythic system which integrates all aspects of her work, and into which autobiographical or confessional details are shaped and absorbed, greatly qualifying how such elements ought to be viewed."231

The mythological framework of Plath's poems, the symbols and the drama, are part of each poem's meaning and illustrates the relationship between the poems within Plath's oeuvre as a whole. The organising structure of the myth is a drama of death and rebirth (which we looked at in chapter two) and almost everything in Plath's poems contributes to either a statement of this problem or offers a vision of its resolution. While Plath's poems contain a plethora of everyday concerns such as politics, ageing, relationships, these subjects are subordinated to the central problem of rebirth being explored in her mythic system. The absorption of Plath's personal, historical concerns into her mythic system explains how the poems' autobiographical elements attain an impersonal and timeless quality. Plath's myth has its origin in her personal history, but it also exerts an influence on her experience. Objects and events are absorbed into the archetypal frame so that the poet and her biography are transformed through the lens of her mythopoeic vision. Furthermore, when details in Plath's historical life do not 'fit' properly into her myth, she alters them "in the spirit of Aristotle's observation that poetry is truer than history". 232

Overlooking this mythic drama is the moon that Hughes described as "a strange muse, bald, white and wild"233 Kroll points out that there are over one hundred direct references to the moon in Plath's poetry. In her earlier efforts these images can be discounted as extraneous references but in the later poems the moon is symbolically integrated into the mythic system. In Plath's mythology the moon functions in a number

\footnotetext{
230 'Chapters in a Mythology'. 1.

231 'Chapters in a Mythology'. 1-2.

232 'Chapters in a Mythology'. 4.

233 'Winter Pollen'. 161.
} 
of interrelated ways. It is her emblematic muse, it symbolises the deepest source and inspiration of her poetic vision, it confirms her vocation as a poet, offers a symbol of her female biology, and confirms her role and 'Fate' as a protagonist in a tragic drama.

According to Kroll, the moon enters Plath's poetry as muse in her 1957 poem, 'The Disquieting Muses', a poem that borrowed its title, imagery and atmosphere from Georgio de Chirico's painting of the same title. In this poem Plath's heroine accepts the prophesy of "those three ladies' (SPC.75), the muses of tragic poetry, and announces that her special poetic vision and destiny as a poet is connected with the wound she received in childhood (her father's death and her mother's refusal to acknowledge the tragedy of life). Subsequently, Plath begins to envision her autobiography as a drama enacted on a stage dominated by the muses. Introducing 'The Disquieting Muses' for a BBC reading, Plath described its three female figures as "a twentieth-century version of other sinister trios of women - the Three Fates". ${ }^{234}$ According to Kroll, Plath had not yet, at this point, developed her own mythology and so, in lieu of a unifying vision and an authentic voice, she borrowed from the "ready-made visions" of others, such as de Chirico, as the speaker of 'Electra on Azalea Path' confesses: "I borrow the stilts of an old tragedy" (SPC. 117). De Chirico's Disquieting Muses and their landscape was helpful to Plath's development in enabling her to envisage a metaphysical landscape where she could stage her psychological dramas. However, Kroll argues, in this early poem, the function of the featureless, bald, luminous, purified heads of these muses was limited by the specificity of their source. The evocation of the muses was too self-consciously calling attention to the poet in the act of myth making. In subsequent poems, Plath solved this problem by identifying the muses with the moon, which, as a feature of the natural world, is free from such limitations as its presence does not have to be explained. The moon can be fantastical and surreal (like the muses), hover naturally above a landscape, or appear in both senses simultaneously; a perfect muse for a poetic that blends myth and biography. ${ }^{235}$

\footnotetext{
${ }^{234}$ Hughes, Ted. (ed.) 'Notes: 1957'. (SPC.276).

235 'Chapters in a Mythology'. 32.
} 
In November 1961, Plath began and completed her poem 'The Moon and the Yew Tree', which Hughes suggested arrived suddenly and unexpectedly after he suggested she use the view from the window above her writing table as a subject for her poem:

Early one morning, in the dark, I saw the full moon setting onto a large yew that grows in the churchyard, and I suggested she make a poem of it. By midday, she had written it. It depressed me greatly. It's my suspicion that no poem can be a poem that is not a statement from the powers in control of our life, the ultimate suffering and decision in us. It seems to me this is poetry's only real distinction from the literary forms we call 'not poetry'. And I had no doubt that this was a poem, and perhaps a great poem. She insisted that it was an exercise on a theme. $^{236}$

While 'The Moon and the Yew Tree' may have begun as an exercise, it ended as a turning point in Plath's poetry in which she identified the moon as her muse. The poem announces Plath's rejection of the familiar and debased patriarchal Christianity and her kinship with the moon, her "mother". Through Plath's mythopoeic lens the matriarchal moon is "not sweet like Mary" but "bald and wild" (SPC.173) and hovers above an unromanticised pagan world. According to Kroll, in this poem Plath became a true poet in the Gravesian sense and found a symbol capable of channelling the energies of the unconscious that would later dominate her mythopoeic drama until her final poems 'Balloons' ("such queer moons we live with") and 'Edge', where the moon stares indifferently "from her hood of bone" at the dead "perfected" woman (SPC.272-3). Plath was familiar with the literary and psychoanalytic archetypes through her psychotherapy and through her college honours thesis readings that included Jung, Frazer, and Freud. Furthermore, as we have already seen, she was introduced to The White Goddess by Hughes shortly after they first met. Graves was in England in November 1961, giving a number of public lectures (Plath appeared at a reading with him), including the three he delivered as Professor of Poetry at Oxford. These talks, incorporated material from The White Goddess, about Graves's notion of the muse and

236 'The Art of Sylvia Plath'. 193-4. 
that of a muse-poet. It is also worth noting that, in The White Goddess, Graves describes a folk belief that "churchyard yews will spread a root into the mouth of each corpse" through which the dead would speak. ${ }^{237}$

According to Graves, the colours of the 'Triple' Moon Goddess are white, red, and black:

I write of her as the White Goddess because white is her principal colour ...the New Moon is the white goddess of birth and growth; the Full Moon, the red goddess of love and battle; the Old Moon, the black goddess of death and divination. $^{238}$

Red, white and black are also the dominant and emblematic colours of Plath's late poems, constituting a system of imagery which is consistent throughout her mythology. In these poems the meaning of these three colours are roughly parallel to that described by Graves. Red is usually associated with vitality, the true self, and with the sought life-indeath, or rebirth. White is associated with the death-in-life existence of the inauthentic self, the false self, and gestation. Black is associated with death and nothingness. ${ }^{239}$

Poems such as 'Tulips', 'Poppies in July', 'Poppies in October' and 'Cut', which at first glance appear to be occasional poems prompted by seeing red flowers or cutting a finger and seeing red blood, are events that are experienced and understood by the poet through her mythic system. The blood redness of the flowers in these poems is experienced by the speaker as "a concrete visual embodiment of the contrast of the energy and vitality of the true self with the stasis, passivity, and numbness of the false self." 240 In 'Tulips', for example, the speaker who has been "swabbed... clear of [her] loving associations" and is "hurt" by the vitality and violence of the flowers because

\footnotetext{
237 'The White Goddess'. 194.

238 'The White Goddess'. 70.

${ }^{239}$ It is worth noting that in 1957, Hughes said of The Hawk in the Rain:"What excites my imagination is the war between vitality and death and my poems may be said to celebrate the exploits of the warriors of either side." In: Brown, Claire and Paterson, Don. Don't Ask Me What I Mean: Poets in their Own Words. London: Picador, 2003. 122.

240 'Chapters in a Mythology'. 17.
} 
"Their redness talks to my wound, it corresponds" (SPC.161). The tulips in their redness functions as "releasers" of the true self that will emerge in the Ariel poems. The speaker senses the danger of this correspondence between the material object and the psychological material, stating: "the tulips should be behind bars like dangerous animals; / They are opening like the mouth of some great African cat," (SPC.162). In 'Ariel' and 'Stings' "the red / Eye / the cauldron of morning," (SPC.240) and the queen bee of 'Stings' "With her lion-red body" and who is a "red / Scar in the sky, [a] red comet" (SPC.215), in the same way, trigger the release of the speaker's "incipient true self". ${ }^{241}$

The relationship between these three colours corresponds to Plath's treatment of the same opposed personae (true and false selves) in the dramatic poems in which these separate aspects of the self are presented as distinct characters in a drama. These poems enact a drama in which the false self is killed in order for the true self to be reborn. In 'Purdah', for instance, the true self is trapped in "the placid, sedentary, doll-like woman" until she "reveals her hidden centre of violence" in order to enact this rebirth of the true self. ${ }^{242}$

The importance of The White Goddess to Plath was not simply its mythopoeic possibilities in being (as we saw in chapter two) one of the earliest, most fundamental narratives for organising human experience. The myth of the Goddess and her dying consort, in which, at least in some variants, the Goddess mourns her dead god, seemed to parallel Plath's own situation mourning her dead "father-sea-god muse". 243 According to Kroll, this mythic drama would impress itself on Plath's lived life more and more, until it seemed to control her fate:

The White Goddess myth, when Plath first encountered it, seemed to order her experience; and continued to do so, and was more and more completely appropriated by her, so that she increasingly saw her life as defined by it. Her

\footnotetext{
241 'Chapters in a Mythology'.18.

242 'Chapters in a Mythology'.18.

243 'The Journals'. 399.
} 
further experiences, particularly of pregnancy and motherhood, were very readily absorbed into this framework. ${ }^{244}$

As a dramatic narrative, Plath's myth begins, like most mythological cycles, in the past and in paradise, which for Plath, was her childhood home in Nauset, Cape Cod. Plath provides an idealised vision of her childhood in her short story 'Ocean 1212W':

My childhood landscape was not land but the end of the land - the cold, salt, running hills of the Atlantic. I sometimes think my vision of the sea is the clearest thing I own. I pick it up, exile that I am, like the purple 'lucky stones' I used to collect with a white ring all the way round, or the shell of a blue mussel with its rainbowy angel's fingernail interior; and in one wash of memory the colors deepen and gleam, the early world draws breath. ${ }^{245}$

In Plath's myth, her father's death was the event that sealed off her childhood, making it appear to her as an inaccessible image of paradise, an Eden from which she had been exiled, and so the idyllic childhood celebrated in 'Ocean 1212W' ends with the death of Plath's father:

And this is how it stiffens, my vision of that childhood. My father died, we moved inland. Whereon those nine first years of my life sealed themselves off like a ship in a bottle - beautiful, inaccessible, obsolete, a fine, white flying myth. $^{246}$

The death of Plath's father is the event that separates her from God, and her true self. As Aurelia Plath said, when Plath learned about her father's death the eight-year old said "I'll never speak to God again!",247 Plath revisits this dramatic event to describe her

\footnotetext{
244 'Chapters in a Mythology'. 42.

245 Plath, Sylvia. 'Ocean 1212-W' [1962]. Johnny Panic and the Bible of Dreams. London: Faber and Faber, 2001 [1977]. 109. Hereafter referred to as 'Johnny Panic and the Bible of Dreams'.

246 'Johnny Panic and the Bible of Dreams'. 116.

247 'Letters Home'. 25.
} 
estrangement from paradise in The Bell Jar in which the heroine, Plath's alter-ego Esther Greenwood, says:

I was only purely happy until I was nine years old. After that - in spite of the Girl Scouts and the piano lessons and the water-color lessons and the dancing lessons and the sailing camp, all of which my mother scrimped to give me, and college, with crewing in the mist before breakfast and blackbottom pies and the new firecrackers of ideas going off every day - I had never been happy again. ${ }^{248}$

Plath was not permitted to attend her father's funeral and Aurelia, believing it to be in the best interests of the children, refused to mourn in front of them. Plath interpreted her mother's undemonstrative behaviour as emotionally cold and as a consequence felt unable to exhibit and resolve her own strong and conflicting emotions of love, hate, anger and grief. Plath's relationship with her mother subsequently became characterised by her need to seek her undemonstrative mother's affections and approval, and her attempts to repay the sacrifices she saw her mother had made in bringing up her brother and herself single-handedly by excelling in her studies and writing. Plath felt her relationship with her mother was one of obligation and guilt and understood her need to seek approval, while inwardly feeling critical of her mother, as an example of her false self and her inauthentic life. In her 1957 poem 'The Disquieting Muses', Plath writes: "Mother, mother... no frown of mine / Will betray the company I keep", (SPC.76) and it is not until her 1962 poem 'Medusa' that she feels able to free the true self from her inauthentic relationship with her mother, announcing: "There is nothing between us" (SPC.226).

The death of Plath's father introduces a period characterised by mourning and stasis and a split in the heroine's psyche between the true and false selves, which we encounter in poems such as 'Electra on Azalea Path' (1958) which gives a biographical explanation for the death-in-life but that is not resolved until the later poems. The drama

\footnotetext{
${ }^{248}$ Plath, Sylvia. The Bell Jar. New York: Harper and Row, 1996 [1962]. 83. Hereafter referred to as 'The Bell Jar'.
} 
within these poems is the heroine's struggle to reconcile her true self and the false self, as Kroll explains:

The protagonist of the late poems is a 'heroine' who has been exiled from paradise by the death of her much-loved, authoritarian father, whom she "thought...was God". His death has left her unable to revise a sense of herself in relation to him ("You died before I had time," as she says in "Daddy"), rupturing her history and marking the point after which nothing was ever the same. ${ }^{249}$

In the Birthday Letters poem 'The Prism', Hughes describes Plath's image of her childhood as "your lucky stone. My unlucky stone” (BL.186). This "beautiful, inaccessible, obsolete, fine, white flying myth" 250 of Plath's childhood was a blessing to her but is a source of grief for the mourning Hughes:

The waters off beautiful Nauset

Were the ocean sun, the sea poured crystal

Behind your efforts. They were your self's cradle.

The image of paradise Hughes refers to in 'The Prism' recurs, often unexpectedly, throughout Plath's writings. In 'Daddy' for example, the speaker connects her father with the "freakish Atlantic", "Where it pours bean green over blue / In the waters off beautiful Nauset"(SPC. 222). The true self that is associated with this unobtainable bliss is equally unobtainable; it is buried with the heroine's father but continues to press its claims without possibility of satisfaction or development. The self that survives the death of her father is a false self that exists in a kind of stasis, a state of death-in-life. The false self is incomplete, ineffectual, powerless, and exists in a kind of unreality. Poems such as 'In Plaster', 'Tulips', 'I am Vertical', 'Blackberrying', 'Poppies in July', 'The Arrival of the Bee Box', 'The Applicant', 'Poppies in October', and 'Paralytic' all detail the death-in-life existence but have not yet discovered the movement towards transcendence

249 'Chapters in a Mythology'. 8.

250 'Johnny Panic and the Bible of Dreams'. 116. 
or rebirth, though they often hint at the possibility of destroying the false self in order to replace it with the true self. Plath discovered the way of resolving this situation in the myth of the Goddess and her consort.

According to Hughes, the myth of the Goddess attracted Plath because it coincided with, and helped to give meaningful shape to, the two most significant events in her personal history, her suicide attempt of 1953 (death), her feeling of emptiness during her period in the McLean hospital (gestation), and her subsequent electroconvulsive treatment (rebirth):

The 'death', so important in all that she wrote after it, was that almost successful suicide attempt in the summer of 1953. The mythical dimensions of the experience seem to have been deepened, and made absolute, and illuminated, by two accidents: she lay undiscovered, in darkness, only intermittently halfconscious, for 'three days'; and the electric shock treatment which followed went wrong, and she was all but electrocuted - at least so she always claimed. Whether it did and she was, or not, there seems little doubt that her 'three day' death, and that thunderbolt awakening, fused her dangerous inheritance into a matrix from which everything later seemed to develop - as from a radical change in the structure of the brain. ${ }^{251}$

Hughes suggests that although Plath "interpreted" her history and experiences through this mythic drama, she still did not yet actually feel 'reborn'. She still felt that she existed in the death-in-life state of the gestation period. Nevertheless, in fusing her personal history with the myth of the Goddess, Plath believed she could uncover and tame her buried true-self in her creative writings, this would trigger the rebirth she sought. In her Journals she writes of sensing that she needed some kind of "catalyst" in order to release her buried inner life into her writings:

251 'Winter Pollen'. 179-180. 
What insight am I trying to get to free what? If my emotional twists are at the bottom of misery, how can I get to know what they are and what to do with them? [Beuscher] can't make me write, or if I do write, write well. She can give me more directives and insight in what I am doing and for what general ends I am doing it. I regress terribly there. I may have all the answers to my questions in myself but I need some catalyst to get them into my consciousness. ${ }^{252}$

Throughout his critical writings Hughes argues that the rebirth Plath sought was the birth of her Ariel voice. According to Kroll, this breakthrough was achieved through her use of the archetypal myth of death and rebirth in the Goddess myth. For Hughes, Ariel is a record of the rebirth of Plath's authentic voice, which had been driven underground during her electro-convulsive treatment and that now returned to confront her unresolved grief and anger relating to her father's death.

In his introduction to Plath's Journals, Hughes retrospectively sees the first indication of the impending rebirth of self in 1959, when Plath had a dream that "had a visionary impact on her". In this dream Plath was "trying to reassemble a giant, shattered, stone Colossus". Hughes argues that "In the light of her private mythology, we can see this dream was momentous, and she versified it, addressing the ruins as 'Father', in a poem which she regarded, at the time, as a breakthrough." 253 In her poem 'The Colossus', the heroine attempts to reassemble the giant stone ruin of her father ("I shall never get you put together entirely" (SPC.129)) but is still unable to "dredge the silt from [his] throat" (SPC.129) and communicate properly with him and describes the "Mulebray, pig-grunt and bawdy cackles / [that] Proceed from [his] great lips" (SPC.129). According to Hughes, a few days later when Plath revisits the same inspiration in her poem 'The Stones', she learns that the Colossus is actually her true self, which she is trying to re-assemble so that it can speak. According to Hughes, in 'The Stones' the "old shattered self, reduced by violence to its essential core, has been repaired and renovated

252 'The Journals'. 474.

253 'Winter Pollen'. 182-3 
and born again, and - most significant of all - speaks with a new voice."254 To Hughes, 'The Stones' was “the culmination of [Plath's] six year 'drama' [of gestation]" 255 and records the moment that the Ariel voice cleared the silt from its throat. The final stage of the process was recorded in the poem 'Elm' when, after a brief struggle with Plath's conscious resistances (which Hughes identifies from the manuscript of the poem 'Elm'), until the true self "suddenly...burst all her restraints and she let it go... And at once the Ariel voice emerged in full, out of the tree. From that day on, it never really faltered again.",256

In 'Elm', Plath faces her 'Other', that aspect of herself that she often identified as Death. This is the self that held her in the grave for three days and had been driven underground at the time of her electro-convulsive treatment. This is the self that is associated with the grief and rage relating to the death of her father when she was eightyears-old. We can see the birth of this true self dramatised in poems such as 'Ariel', 'Fever $103^{\circ}$ ' and 'Getting There'. The poem 'Ariel' tells the whole story of the drama, beginning with a description of the heroine trapped in her death-in-life existence as being "Stasis in darkness" (SPC.239). The poet then, as in 'Lady Lazarus', describes the dissolution of the false self, or the false self's death and dismemberment as a kind of striptease: "White / Godiva, I unpeel - / Dead hands, dead stringencies" (SPC.239). Following the death of the false-self, the poem ends with the rebirth of the true self:

And I

Am the arrow,

The dew that flies

Suicidal, at one with the drive

Into the red

Eye, the cauldron of morning.

(SPC. 239-240)

\footnotetext{
254 'Winter Pollen'. 182-3

255 'Winter Pollen'. 183.

256 'Winter Pollen'. 188.
} 
In 'Fever $103^{\circ}$ ', as in 'Lady Lazarus', the same drama of death and rebirth is enacted through fire. The heroine initially burns in the "tongues of hell" (SPC. 231).

The smoke from her burning "will not rise" but "trundle[s] around the globe" (SPC. 231) engulfing the heroine in its heavy atmosphere. However, as the poem closes, the flames of her suffering become a pyre on which the heroine achieves purification and transcendence:

I think I am going up,

I think I may rise -

The beads of hot metal fly, and I, love, I

Am a pure acetylene

Virgin

Attended by roses,

By kisses, by cherubim,

By whatever these pink things mean.

Not you, nor him

Not him, nor him

(My selves dissolving, old whore petticoats) -

To Paradise.

(SPC. 232)

The movement of 'Fever $103^{\circ}$ ' from hell to paradise involves the annihilation, through fire, of the false self, enabling the rebirth of the true self. 'Getting There' is another poem that has often been interpreted by critics as a 'death wish'. However, now that we are familiar with the mythic drama behind the Holocaust imagery, we can see that the poem resolves with a rebirth of the true self as a pure newborn baby:

The carriages rock, they are cradles.

And I, stepping from this skin

Of old bandages, boredoms, old faces 
Step to you from the black car of Lethe,

Pure as a baby.

(SPC. 249)

The final confirmation of Plath's identification with the Goddess, the "catalyst" she sought in her Journals to utilise in her creative writing came when she learned of Hughes's affair with Assia Wevill. Plath experienced her separation from Hughes as a reoccurrence of her father's abandonment, as she commented in her Journals on 3 January 1959:

All my life I have been "stood up" emotionally by the people I loved most: Daddy dying and leaving me, mother somehow not there. So I endow the smallest incidents of lateness, for example, in other people I love, with an emotional content of coldness, indication that I am not important to them. ${ }^{257}$

According to Hughes, Plath experienced her separation from Hughes as a recurrence of her abandonment by her father:

The Ariel poems document Plath's struggle to deal with a double situation - when her sudden separation from her husband coincided with a crisis in her traumatic feelings about her father's death which had occurred when she was eight years old (and which had been complicated by her all but successful attempt to follow him in a suicidal act in 1953). ${ }^{258}$

This situation in her outer world corresponds with, and triggers the release of, the unresolved grief and anger associated with her father's death that had gone underground at the time of her electro-convulsive treatment. Plath's Journals show that, even before the breakdown of her marriage, she conflated Hughes with her father. On 27 December 1958, for example, she describes a dream in which she chases Hughes through a "huge

257 'The Journals'. 455.

258 'The Journals'. 191. 
hospital". In this dream, Hughes is with another woman and yet it is not him: "What makes you think it was Ted?" she asks herself, "It had his face but it was my father, my mother". She goes on:

I identify [Hughes] with my father at certain times, and these times take on great importance: eg that one fight at the end of the school year when I found him notthere on that special day and with another woman. I had a furious access of rage. He knew how I love him and felt, and yet wasn't there. Isn't this an image of what I feel my father did to me? I think it may be. The reason I haven't discussed it with Ted is that the situation hasn't come up again and it is not a characteristic of his: if it were, I would feel wronged in my trust on him. It was an incident only that drew forth echoes, not the complete withdrawal of my father who deserted me forever... Ted, insofar as he is a male presence is a substitute for my father: but in no other way. Images of his faithlessness with women echo my fear of my father's relation with my mother and Lady Death. How fascinating all this is. Why can't I master it and manipulate it and lose my superficiality which is a protective gloss against it? ${ }^{259}$

Hughes's "faithlessness" and 'abandonment' of Plath was the culminating confirmation of her assimilation of her autobiography and the myth, as Kroll puts it, "by this time her sense must have been that the White Goddess mythology had appropriated her, as her fate - that her life was magically entwined with the myth."260

In the final development of Plath's mythic drama the male protagonist (or the mother as in 'Medusa') takes over the burden of suppressing the heroine's inaccessible true self. It is now the speaker's attachment to her husband (like her earlier attachment to her father) that is responsible for her inauthentic existence. The heroine of the drama in these poems has been mistreated and rejected by her personal 'god'. The male god (the father and/or husband) is now exposed as a devil or a similar figure, which gives the

259 'The Journals'. 447.

260 'Chapters in a Mythology'. 42. 
heroine a basis for rejecting him, and in rejecting or usurping his power, freeing the true self from his power.

In poems such as 'The Applicant' and 'Purdah' the speaker has been made unreal in different ways by men. The basic relationship the poems describe is that of oppressor and oppressed, master and slave, torturer and tortured, creator and object. The false self in these dramatic poems is associated primarily with male-defined roles, the "living doll" (SPC. 221) of 'The Applicant' and as the "Lever of his wet dreams" in 'The Jailer' (SPC. 226). Now, the speaker's authentic existence, her true self, associated with vitality, artistic creativity and autonomy, is reborn through a rejection of the limits imposed on her identity by the male protagonist. In 'Stings', for example, the "honey-drudger" leaves the "mausoleum" to become the queen bee (SPC. 214).

Now the heroine throws off her disguise and emerges in the image of the true self. In these poems the death of the male god is not mourned but is celebrated. Instead of killing the false-self the heroine now kills the scapegoat male (bridegroom / husband / father) in order to release herself from his power. In 'Lady Lazarus', 'Purdah' and 'Daddy', there is a dramatic description of the ritual sacrifice that is necessary for rebirth. In 'Daddy' the false self has "lived like a foot / For thirty years, poor and white, / Barely daring to breathe or Achoo" (SPC. 222) and must kill her Daddy-husband figure to restore the balance. The false self is also the submissive "small jewelled / Doll" (SPC. 244) of 'Purdah' that is replaced by the "lioness" (SPC.244) Clytemnestra figure. In 'Lady Lazarus' the heroine arises from the ash to "eat men like air" (SPC.247). The death of the male protagonist allows the rebirth of the heroine's true self, allowing her to achieve wholeness and overcome the difficulty of her situation triumphantly. In several of her dramatic poems, such as 'Lady Lazarus', 'Daddy' and 'Purdah', Plath speaks as the Goddess in some of her many incarnations so that her life and the myth become indistinguishable. The myth no longer acts as a metaphor for the life but is the life. As Charles Newman has commented: "There is a new swift, breathless tone... in these later 
poems... the self-conscious sleight-of-hand is absorbed. The terms of her private war have escalated. She is becoming the myth of herself." 261

Hughes explains the difficulty of reconciling these triumphant poems with Plath's subsequent suicide by suggesting the victory of these poems was only temporary. According to Hughes, by December 1962, Plath "knew she had written beyond her wildest dreams. And [that] she had overcome, by a stunning display of power, the bogies of her life."262 He suggests Plath's victory in this battle was evident in her outward demeanour: "the impression of growth and new large strength in her personality was striking."263 However, Plath's attitude to the poems was "detached" and after writing up to three poems a day for several months "she seemed to be under no compulsion to start writing again." 264 After making a small revision of the poem 'Sheep in Fog', a poem she had started in October but had kept out of Ariel, she did not write again, until 28 January 1963, when she returned to 'Sheep in Fog' and began to follow what she described as a "different, cooler inspiration",265

The manuscript drafts illustrate that when she returned to 'Sheep in Fog' she changed the ending of the poem from a symbol of rebirth ("clouds with the faces of babies") ${ }^{266}$ to a symbol of death ("Starless and fatherless, a dark water" (SPC.262). According to Hughes, 'Sheep in Fog' marks "a moment of decisive psychological change", ${ }^{267}$ and records the moment in which, as far as Plath is concerned, her endeavour in Ariel had failed.

Hughes points out that 'Sheep in Fog' like the earlier poem 'Ariel', was about a ride over Dartmoor on her horse (called Ariel). In the drafts of the later poem, Hughes

\footnotetext{
${ }^{261}$ Newman, Charles. 'Candor is the Only Wile' [1966]. The Art of Sylvia Plath. USA: Indiana University Press, 1971. 48.

262 'Winter Pollen'. 188.

263 'Winter Pollen'. 188-9.

264 'Winter Pollen'. 189.

265 'Winter Pollen'. 189.

${ }^{266}$ Hughes, Ted. 'The Evolution of Sheep in Fog'. [1988]. Winter Pollen: Occasional Prose. Faber and Faber. London, 1994. 197. Hereafter referred to as 'Winter Pollen'.

267 'Winter Pollen'. 207.
} 
identifies a number of discarded images and phrases including the word "melt" and "a broken chariot", which, he suggests, indicates a shift in the mythopoeic frame behind the poem from the myth of Phaeton in 'Ariel', where Plath's thrilling ride enables a purifying fiery rebirth as "dew" in the "cauldron of morning" (SPC.240), to the myth of Icarus, in 'Sheep in Fog' where, in flying too near the sun, the rider has fallen "fatherless" into "a dark water" (SPC.262).

A cursory glance at the contents page of Birthday Letters shows that many of Hughes's poems take their titles from Plath's poems and other writings. Looking at the poems we become aware that the poems are saturated with Plath's language, themes, images, symbols, and revisit the events she described in her writings. Susan Bassnett has suggested that, in this way, Birthday Letters can be understood as a translation of Sylvia Plath's writings:

Birthday Letters is... both an original collection of startlingly personal works, and a translation of the work of another poet, a translation that, as all good translations must, reconstructs and re-examines the texts that provide the point of departure. ${ }^{268}$

As translation, Birthday Letters can be seen as a dramatisation of Hughes's interpretation of Plath's work, as being the story of the birth of Ariel, and the story of the rebirth of Plath's true self. The Birthday Letters poems arrange themselves obsessively around the mythopoeic terms of Plath's psychic drama, calling out to each other through their motifs, symbols and dramatic metaphors.

The first significant event in Plath's myth, as we have seen, is the death of her father, which leads to her estrangement from her true self and her suicide attempt of 1953, which becomes the 'Death' of her myth. In Birthday Letters, Hughes dramatises this idea in 'The Shot' by tracing the ferocious trajectory of Plath's brief life and career through the metaphor of a bullet that is discharged by her father's death:

268 'Plath Translated'. 139-40. 
Your Daddy had been aiming you at God

When his death touched the trigger.

In that flash

You saw your whole life. You ricocheted

The length of your Alpha career

With the fury

Of a high-velocity bullet

That cannot shed one foot-pound

Of kinetic energy.

Hughes's description of Plath's 'trajectory' in 'The Shot' highlights the importance of the death of Plath's father in the development of her mythic drama. In 'The Shot', Otto Plath is the idealised father-God, whose loss is mourned, in Plath's earlier poems ('Full Fathom Five', 'Electra on Azalea Path', 'The Bee Keeper's Daughter' and 'The Colossus'). As she said in her Journals: "I never knew the love of a father, the love of a steady blood-related man after the age of eight."269 According to Birthday Letters, Plath is unable to accept the loss of her father-God and in order to avoid the fact of his absence she projects his image onto her lovers:

Your worship needed a god.

Where it lacked one, it found one.

Ordinary jocks became gods -

Deified by your infatuation

That seemed to have been designed at birth for a god.

It was a god-seeker. A god finder.

Plath's Journals contain a number of entries that support the dramatic situation described in 'The Shot'. As early as 1950, recalling, in second-person, a discussion with friends about a blind date with an "older" man Plath comments: "You make some crack

269 'The Journals'. 431. 
about going in for the fatherly type. Your own father is dead."270 Six years later, on 25 February 1956, only hours before meeting Hughes at the St Boltoph's party she writes: "Went to psychiatrist this morning and liked him: attractive, calm and considered, with that pleasant feeling of age and experience in a reservoir; felt: Father, why not? Wanted to burst out in tears and say father, father, comfort me."271 Then, on 8 March 1956, two weeks after her first encounter with Hughes, she again reproaches herself for being attracted to another older man whom she conflates with her father:

I rail and rage against the taking of my father, whom I have never known; even his mind, his heart; his face, as a boy of 17 I love terribly. I would have loved him; and he is gone... I lust for the knowing of him. I looked at Redpath at that wonderful coffee session at the Anchor, and practically ripped him up to beg him to be my father; to live with the rich chastened, wise mind of an older man. I must beware, beware of marrying for that. Perhaps a young man with a brilliant father. I could wed both. ${ }^{272}$

'The Shot' does not challenge the 'truth' or validity of Plath's identification of Hughes with her idealised father-God but adopts the terms of her subjectivity. In this way, Hughes argues that he is not unusual among Plath's lovers in his inability to perform the impossible role she casts for; her earlier lovers also fail to meet her expectations. In her Journals, Plath comments: "I hated men because they didn't stay around and love me like a father: I could prick holes in them \& show they were no father material." ${ }^{273}$ Nevertheless, this insight does not prevent her from repeating this obsessive identification. In 'The Shot', as in 'Daddy', character drives Fate and Plath is not diverted from her real target by the deflections of these lovers who "were not father material". 'The Shot' suggests that Plath's unlikely survival following her suicide attempt of 1953 does not halt her course either, but provides the material for the mythic drama that will eventually resurrect her father:

\footnotetext{
270 'The Journals'. 40.

271 'The Journals'. 209.

272 'The Journals'. 230.

273 'The Journals'. 431.
} 
Even the cheek-scar

Where you seemed to have side-swiped concrete,

Served as a rifling groove

To keep you true.

Till your real target

Hid behind me. Your Daddy,

The god with the smoking gun. For a long time

Vague as mist, I did not even know

I had been hit,

Or that you had gone clean through me -

To bury yourself at last in the heart of the god.

(BL.16-7)

In 'The Shot', Hughes describes unwittingly stepping into the trajectory line of Plath's journey into the heart of her "real target", she passes clean through him and is finally reunited with her father in death. It is important to remember that in 'The Shot' Hughes is not providing a psychological diagnosis of Plath in order to pathologise her but is representing, in dramatic terms, his reading of the self Plath described in her writings. Plath's sessions with her psychiatrist Beuscher may have emphasised the significance of her father's death in her psychoanalytical sessions but it is Plath who uses these insights to produce poems that require Freudian hermeneutics.

In Birthday Letters, Hughes records the moment of Plath's conflation of Hughes with her father in 'Black Coat'. In this poem, which provides the biographical situation behind Plath's 'Man in Black', he recalls taking a late walk, alone, on a beach: "Trying to feel thoroughly alone, / Simply myself, with sharp edges" (BL.102). As he walks along the beach he is not aware that Plath is observing him:

I had no idea I had stepped

Into the telescopic sights

Of the paparazzo sniper 
Nested in your brown iris.

(BL.102-3)

The beach walk Hughes recalls in 'Black Coat' is significant in terms of Plath's textual transformation of him, and anticipates her portrayal of him as the "man in black" of 'Daddy' (SPC.224). Plath's Journal entry for 9 March 1959 (the day she first visited her father's grave) records Hughes's walk on the beach faithfully enough: "Ted out at the end of the bar, in black coat, defining the distance of stones and stones humped out of the sea". ${ }^{274}$ However, when the scene re-emerges in her syllabic 'Man in Black', Hughes's physical presence, between the beach headland, the sea, and the rock pools, has become the axis of her vision, the point that holds the earth and sky together:

And you, across those white

Stones, strode out in your dead

Black coat, black shoes, and your

Black hair till there you stood,

Fixed vortex on the far

Tip, riveting stones, air,

All of it, together.

(SPC.119-20)

In 'Black Coat', Hughes suggests that Plath's description of himself in 'Man in Black' is the moment when her identification of himself with her father-God is realised in her poetry:

Set up like a decoy

Against that freezing sea

From which your dead father had just crawled.

I did not feel

How, as your lenses tightened,

274 'The Journals'. 473. 
He slid into me.

As we have seen, in Hughes's interpretation of Plath's poems as the resolution of a psychological crisis, he suggests that, in the Ariel poems, Plath faced the unresolved feelings associated with her father's death. In Birthday Letters, Hughes represents Plath's preoccupation with her father dramatically as a haunting, in which Otto Plath is cast as a jealous lover returning to tempt his daughter to rejoin him. In a number of the Birthday Letters poems Otto appears as a spectre directing the drama from the wings and ensuring that Hughes and Plath perform their roles to ensure his resurrection. In 'The Hands', for example, Hughes dramatises the control that Otto Plath has of Plath's imaginative and emotional life. The same hands that "Dandled [Plath's] infancy" also "Positioned [her] in the crawl space / And fed [her] the pills" (BL.184) during her 1953 suicide attempt. These same hands "left big fingerprints" (BL.184) in her poems and wore Plath's "last stand letters "like gloves / inside those words you struck me with...And that still ring in my ears" (BL.184). In this way, Hughes dramatises his notion that the anger and grief Plath directed at Hughes in her Ariel poems related to the "double situation" of her father and her husband's separate abandonments.

In other Birthday Letters poems, Hughes dramatises the notion that his actions resurrected Plath's grief and anger at her father's abandonment. In these poems, he uses euphemistic situations to describe how his actions, which must properly include his infidelity, allow Otto Plath into their home at Court Green. In 'The Table', he suggests that, in building Plath a writing desk from a "broad elm plank" that has been "Rough-cut for coffin timber" (BL.138), he unwittingly "made and fitted a door / Opening downwards into your Daddy's grave” (BL.138). Similarly, in 'The Bee God', he describes building Plath a beehive that provides her father with access to her imaginative life:

When you said you wanted bees I never dreamed

It meant your Daddy had come up out of the well.

(BL. 150) 
Otto Plath was, of course, a professor of entomology whose specialist subject was bees and he was apparently called the "Beinen-Konig" ("the Bee King") by his college friends. In 'The Bee God', Plath's beekeeping ambitions are shown to be symptomatic of her father worship:

... you bowed over your bees

As you bowed over your Daddy.

Your page a dark swarm

Clinging under the lit blossom.

You and your Daddy there in the heart of it,

Weighing your slender neck.

I saw I had given you something

That had carried you off in a cloud of gutturals -

The thunderhead of your new selves

Tending your golden mane.

In 'The Bee God', the "furious Latin" (SPC.213) in Plath's 'The Arrival of the Bee Box' becomes "a cloud of gutturals" in which Plath hears her father's native German. The symbol of the "golden mane" of bees recalls the "lioness" of 'Ariel' and 'Purdah' (SPC. 239, 244) and the "lion-red" queen bee of 'Stings' (SPC.215), and may also refer to the ancient Greek belief that bees came from the dead corpses of lions. ${ }^{275}$

In Bundtzen's interpretation of Birthday Letters as a retelling of the myth of Orpheus and Eurydice, Otto Plath takes the role of Aristaeus the beekeeper who, according to the Greek myth, was pursuing Eurydice when she was killed. In 'The Bee God', as in the myth of Orpheus, Otto and his double Hughes are rivals who contend for

275 This ancient belief is recorded in the biblical story of Samson and in the Greek myth of Aristaeus. 
possession of Plath. Hughes revisits the event described in Plath's 'Stings' when he was stung by a number of the bees. In 'Stings', Plath suggests that the bees sting Hughes in vengeance for his betrayal:

The bees found him out,

Moulding onto his lips like lies,

Complicating his features.

(SPC.215)

In 'The Bee God, however, Hughes reworks this logic to suggest that his features were complicated by Plath's conflation of himself and her father, and that the stings in Plath's poems were directed by this "double situation". Consequently, the bees that sting Hughes in 'The Bee God' are "Fanatics for their God, the God of the Bees" (BL.152), alias Otto Plath, and are only following his orders:

You did not want me to go but your bees

Had their own ideas.

You wanted the honey, you wanted those big blossoms

Clotted like first milk, and the fruit like babies.

But the bees' orders were geometric Your Daddy's plans were Prussian.

When the first bee touched my hair You were peering into the cave of thunder.

That outrider tangled, struggled, stung Marking the target.

And I was flung like a headshot jackrabbit Through sunlit whizzing tracers 
As bees planted their volts, their thudding electrodes, In on their target.

(BL. 151)

Hughes's description of the stings as "volts" and as "electrodes" recalls Plath's electroconvulsive treatment and links his punishment with her rebirth. Plath described this treatment in her poem 'The Hanging Man': ("By the roots of my hair some god got hold of me. / I sizzled in his blue volts like a desert prophet" (SPC.141)). Hughes inserted this poem into the version of Ariel that he published in 1965 because he believed it was "the experience that made Ariel possible" ${ }^{276}$ in that it provided Plath with the rebirth event that followed Plath's three day death. Hughes recalls her electro-convulsive treatment in 'The Tender Place', which echoes the language of 'The Hanging Man':

Somebody wired you up

Somebody pushed the lever. They crashed

The thunderbolt into your skull.

In their bleached coats, with blenched faces,

They hovered again

To see how you were, in your straps.

Whether your teeth were still whole.

...Terror was the cloud of you

Waiting for these lightnings. I saw

An oak limb sheared at a bang.

You your Daddy's leg. How many seizures

Did you suffer this god to grab you

By the roots of the hair?

In 'The Tender Place', as in Hughes's critical writings, the electro-convulsive treatment does not resolve Plath's 1953 crisis but simply causes her true voice to "dive inwards" underground, only to re-emerge, years later in her Ariel poems:

276 'Winter Pollen'. 167. 


\section{The lights}

In the Senate House dipped

As your voice dived inwards

Right through the bolt-hole basement.

Came up, years later,

Over-exposed like an X-ray -

Brain-map still dark-patched

With the scorched-earth scars

Of your retreat. And your words,

Faces reversed from the light,

Holding in their entrails.

(BL.12-3)

In 'The Tender Place', Plath's true voice goes underground in the same way that she hid herself in the basement of her mother's house at the time of her 1953 suicide attempt. When the words of Plath's true voice are finally recovered in her Ariel poems, they follow the "brain map" of her death and rebirth myth. Hughes explains what he sees as Plath's obsessive loyalty to her rebirth scenario in her writings as being a result of the way that, in being connected with her electroconvulsive treatment, this mythic motif has become "scorched" into her imagination. Consequently, the recovered words of Plath's true self are "over-exposed like an X-ray"277 in the sense that they bear the "brain-map" traces of their journey.

While poems like 'The Tender Place' deal with specific 'chapters' in Plath's mythology, two Birthday Letters poems, 'The God' and 'Suttee', each provide a complete account of Hughes's interpretation of Plath's psychological drama from beginning to end. In his introduction to Plath's Journals, Hughes described the birth of the Ariel-voice in religious terms: "This kind of "birth" he suggests "is usually found in

277 The line "Overexposed, like an X-ray" appears in Plath's poem 'Medusa' (SPC.224) 
the context of a religion, or at least of some mystical discipline. It is rare in secular literature. ${ }^{278}$ In the Journals, Plath describes her writing in similar terms:

Writing is a religious act: it is an ordering, a reforming, a relearning and reloving of people and the world as they are and as they might be. A shaping which does not pass away like a day of typing or a day of teaching. ${ }^{279}$

In 'The God', Hughes depicts Plath as a "religious fanatic" praying to recover the 'story', or the 'myth', of her inspiration, bent over her page, subjugated to her inspiration:

You were like a religious fanatic

Without a god - unable to pray.

You wanted to be a writer.

Wanted to write? What was it within you

Had to tell its tale?

The story that has to be told

Is the writer's God, who calls

Out of sleep, inaudibly: 'Write.'

Write what?

(BL. 188)

In 'The God', Hughes dramatises his belief that Plath's poems were inspired. Plath feels empty in the gestation period because, although she knows that something within her wants to be heard, she cannot initially hear the Ariel voice that is her God. But, because the God is all that she wants, she offers it sacrifices to conjure its magic:

You offered him verses. First

Little phials of the emptiness

Into which your panic dropped its tears

278 'Winter Pollen'. 184.

279 'The Journals'. 436. 
These phials of emptiness are Plath's images of the false self, the death-in-life heroine. In return for her offering, Plath's inspiration conjures an image, a pagan "idol" on her page in the shape of the moon:

Your silent howl through the night

Had made itself a moon, a fiery idol

Of your God.

Your crying carried its moon

Like a woman and a dead child.

(BL. 189)

The appearance of the moon on Plath's page here recalls the moment when, according to Kroll, Plath discovers her moon Muse while writing 'The Moon and the Yew Tree'.

In 'The God', Hughes describes the moon as carrying a child; this is a dramatic depiction of the gestation period of the Ariel voice before the rebirth of self that is recorded in the 'Elm'. This is the "oracular foetus" 280 of Ariel feeding on Plath's inner crisis:

So I nursed you, who nursed a moon

That was human but dead, withered, and

Burned you like a lump of phosphorous.

Till the child stirred. Its mouth-hole stirred.

Blood oozed at your nipple,

A drip-feed of blood. Our happy moment!

(BL. 189)

The child of the moon-muse is malignant and feeds on Plath's suffering, her nightmares, and her fears. It is the voice of her true self, still suffering her unresolved grief for the death of her father. The child of the moon is also the "little god" (SPC.173) of Plath's

280 'Winter Pollen'. 186. 
poem 'Mirror', which can only tell the truth, and it is also the "dark thing" released in the poem, 'Elm', “Looking, with its hooks, for something to love” (SPC. 193):

The little god flew up into the Elm Tree.

In your sleep, glassy-eyed,

You heard its instructions. When you woke

Your hands moved. You watched them in dismay

As they made a new sacrifice.

Two handfuls of blood, your own blood,

And in that blood gobbets of me,

Wrapped in the tissue of a story that had somehow

Slipped from you. An embryo story.

(BL.189-90)

The "little god" that speaks only the truth now directs Plath's hands as she attempts to divine its message following its instructions. The "embryo story" feeds on the blood sacrifice of Plath's and Hughes's historical identities and their actions.

When the little god is born, Hughes finds himself transplanted onto the dark stage of Plath's drama and playing a role in the new myth that has enveloped him:

Blinded I struck a light

And woke upside down in your spirit-house

Moving limbs that were not my limbs,

And telling, in a voice not my voice,

A story of which I knew nothing

In the closing lines of 'The God', Plath is described as making a religious offering of "the myrrh of [her] mother / The frankincense of [her] father / And [of her] own 
amber" (BL.190) in a fiery sacrifice to the nativity of the God, her saviour (as Plath said of the Ariel poems "They saved me"281), who "snuff[s] up the fatty reek" (BL.190).

Hughes describes Plath as "in a fury weeping" as her inspiration takes hold and she begins to write the poems that consume her identity her "joy" is "a trance dancer / In the smoke of the flames" (BL.191). Finally, in the last line of the poem, Hughes gives the name of this God that can only speak in euphemisms: "Grief” (BL.191), suggesting, again, that the myth that consumed him and Plath was largely a result of Plath's mythopoeic resolution of her grief for her father's death.

The other Birthday Letters poem that provides a dramatic description of the birth of Plath's creative self is 'Suttee'. The title of this poem refers to the (now rare) cultural practice among Hindu widows of throwing themselves onto the funeral pyre of their husbands to demonstrate their love. In this way Hughes implies that the birth of Plath's creative self is also the delivery of a self-destructive form of grief and martyrdom. Like 'The God', 'Suttee' begins by dramatising the "strange period of 'gestation / regeneration, which followed [Plath's symbolic] 'death", 282 by depicting Plath and Hughes awaiting their arrival of a child, without quite knowing what it will be:

In the myth of your first death our deity

Was yourself resurrected.

Yourself reborn. The holy one.

Day in day out that was our worship -

Tending the white birth-bed of your rebirth,

The unforthcoming delivery, the all-but-born,

The ought-by-now-to-be-born.

In 'Suttee', Hughes and Plath look forward to the rebirth promised in Plath's myth, which she aims to achieve in her writing, but both are unsure as to how successful the birth will

281 'Winter Pollen'. 188.

282 'Winter Pollen'. 207. 
be. The gestation period is described as a "gruelling prolongueur" (BL.147) that is characterized by Plath's fear of the consequences. As Hughes has said in his critical writings, Plath feared her inspiration: "her materials, after all, were the real explosive experience of her own life and attempted suicide." ${ }^{283}$ In facing her inspiration, Plath was forced to face "the bogies of her life", ${ }^{284}$ which having escaped from their underground hideaway, now demanded her attention:

Your labour frightened you.

What was trying to come frightened you.

You had no idea what it might be -

Yet it was the only thing you wanted.

Night after night, weeks, months, years

I bowed there, as if over a page,

Coaxing it to happen,

Laying my ear to our unborn and its heartbeat, Assuaging your fears. Massaging

Your cramps into sleep with hypnosis

And whispering to the star

That would soon fall into our straw -

Hughes and Plath anticipate the birth in Messianic terms. They envisage a nativity scene rather than a sacrificial martyrdom. In spite of this, their hopes are also their fears:

What would you be - begotten

By that savage act of yours committed

On your body, battering your face to the concrete,

Leaving yourself for dead

(And hoping you were dead) for three days?

\footnotetext{
283 'Winter Pollen'. 480.

284 'Winter Pollen'. 188-9.
} 
We feared

Our new birth might be damaged,

Injured in that death-struggle conception.

Plath sensed that her inspiration was malignant and in the poem in which it emerged she provided an image of the inspiration she felt stirring within her and that disturbed her dreams as a "cry" and a kind of bird:

I am inhabited by a cry.

Nightly it flaps out

Looking, with its hooks, for something to love.

I am terrified by this dark thing

That sleeps in me;

All day I feel its soft, feathery turnings, its malignity.

(SPC.193)

For Hughes, Plath's courage in confronting the "dark thing" of her inspiration was part of the achievement of Ariel, and explained why such breakthroughs are so rare. As he said in a 1982 essay: "The seriousness, finally, of her will to face what was wrong in herself, and to drag it out into examination, and to remake it - that is what is so impressive. Her refusal to rest in any halfway consolation or evasive delusion... It would not be so impressive if she were not so manifestly terrified of what she nevertheless did." 285

After the gestation period, 'Suttee' describes the birth that Hughes and Plath had awaited for so long; as the Ariel-voice is born, Hughes is engulfed in the birth waters:

Till suddenly the waters

Broke and I was dissolved.

Much as I protested and resisted

I was engulfed

285 'Winter Pollen'. 182. 
In a flood, a dam-burst thunder

Of new myth.

(BL. 148)

Hughes describes himself protesting and resisting this "new myth" that engulfs and dissolves him, as, in his role as Plath's abandoning God, he is burdened with the unresolved grief that went underground during her electro-convulsive treatment. As Plath's labour cries subside, he hears not "the cries / of the newborn" or "the wauling of joy" but "the screams / Of the mourner... / A scream stuck in a groove - unstoppable" (BL.148):

And you had been delivered of yourself

In flames. Our newborn

Was your own self in flames.

And the tongues of those flames were your tongues.

I had delivered an explosion

Of screams that were flames.

(BL. 148-9)

In his description of this fiery rebirth, Hughes adopts the dramatic terms of Plath's poems such as 'Lady Lazarus', 'Ariel', 'Fever 103', and the 'Witch Burning' section of 'Poem for a Birthday' to describe the rebirth of Plath's true self in her Ariel poems. However, in Birthday Letters, this is not a burning of purification; it is a senseless martyrdom, a sacrifice of self, and the flames of this sacrificial pyre are fuelled by Plath's tears.

In 'Suttee', Hughes describes himself in a midwife role as encouraging and reassuring Plath in her creative efforts. Plath's Journals indicate that Hughes did assist Plath in her writing efforts by setting her writing exercises and encouraging her to try different methods to communicate with her unconscious such as experimenting with the Ouija board. In one Journal entry of October 1959, Plath writes:

I tried Ted's "exercise": deep breathing, concentration on stream-of-conscious objects, these last days, and wrote two poems that pleased me. One a poem to 
Nicholas, ${ }^{286}$ and one the old father-worship subject. ... So I have three poems for the new [book] temporarily called THE COLOSSUS and other poems. ${ }^{287}$

However, we can also interpret Hughes's midwife role to the birth of the Ariel-voice as a euphemistic metaphor for his infidelity. Hughes is midwife to this rebirth in the sense that his 'abandonment' of Plath triggers the resurrection of Plath's unresolved grief, and confirms her identification of Hughes and her father in the myth that will now control the drama of her poems and their lives:

'What are these flames?' was all I managed to say,

Running with my midwife's hands

Not to wash them, only to extinguish

The screeching flames that fed on them and dripped from them.

I could not escape the torching gusher.

(BL. 149)

Hughes is not attempting to 'wash his hands' of responsibility for assisting with the birth of Plath's buried grief; he is attempting to extinguish the flames of the "new myth" that is consuming his actions.

The final section of 'Suttee' deals with the tragic consequences of the Arielvoice's emergence. Hughes describes Plath as "a child-bride" to reflect his notion of Plath's fiery sacrifice in her double role as her father's child and her husband's bride:

You were a child-bride

On a pyre.

Your flames fed on rage, on love

And your cries for help.

Tears were a raw fuel.

And I was your husband

\footnotetext{
${ }^{286}$ Plath was pregnant with Frieda at this time. Nicholas would have been the name of the child had it been a boy.

${ }^{287}$ ‘The Journals'. 518.
} 
Performing the part of your father

In our new myth -

Both of us drenched in a petroleum

Of ancient American sunlight,

Both of us consumed

By the old child in the new birth -

Not the new babe of light but the old

Babe of dark flames and screams

That sucked the oxygen out of both of us.

(BL. 149)

The "new myth" sucks the oxygen out of both Plath and Hughes in the sense that it consumes their active historical identities and forces them perpetually to perform the roles demanded in the drama. In the next chapter we will look at how Birthday Letters contends with this myth that he describes consuming his identity and his actions. 


\section{Re-writing the Myth}

In the previous chapter we saw that Birthday Letters can be seen as an interpretation of Plath's life and writings through the mythic drama Hughes discovers in her poems. However, Birthday Letters is not simply an interpretation of Plath's myth but a means for Hughes to contend with the role he has been assigned in it. Hughes contends with this myth by highlighting the partiality of Plath's mythic vision, and challenges her account by altering the dramatic roles and symbols in her drama, which enables him to re-assert his own equally subjective version of events. We have seen that the poem 'Suttee' ends with Hughes and Plath being “drenched in a petroleum / Of ancient American sunlight" and "consumed" in the "dark flames" of "new myth", which "sucked the oxygen out of both of [them]" (BL. 149). In this chapter we will look at how Hughes attempts to free himself and Plath from the myth that consumed their identities, their history, and their actions.

The myth that Hughes contends with was supported and perpetuated in the biographies and critical commentary on Plath's writings. Hughes resituates his own version of their story in a new matrix of discourses drawn from a wide range of literary works, ancient myths, and folk tales. Birthday Letters is a story about stories. It is a story about the myths we live by, and that enable us to make sense of our own lives and the lives of others. So far, we have limited our examination of 'the myth of Sylvia Plath' in terms of Plath's own mythopoeic translation of her history and experiences. However, as Rose has pointed out, the meaning of Plath's mythopoeic writings is beyond her control and is established in the discourses surrounding her writings:

Interpretation of a literary work is endless. There is no one true place where it can be halted... Once a piece of writing is put into circulation, it ceases - except in the most material sense - to be the property of its author. ${ }^{288}$

288 'The Haunting of Sylvia Plath'. xi. 
The archetypal drama of death and rebirth that Hughes identifies in Plath's poems is one of the most fundamental narrative structures for organising human experience. Consequently, Plath's writings have served a number of interpretations over the past 40 years. Because Hughes features so prominently in Plath's writings, the meaning of his life and his actions have also been endlessly interpreted in a group of discourses that have been beyond his control. Hughes commented on this "problem" in a letter to Andrew Motion:

The main problem with S.P.'s biographers is that they fail, at the outset, when they embark on the book they hope will sell a lots of copies, to realize that the most interesting and dramatic part of S.P.'s life is only $1 / 2$ S.P. - the other $1 / 2$ is me. They can caricature and remake S.P. in the image of their foolish fantasies, and get away with it - and assume, in their brainless way, that it's perfectly O.K. to give me the same treatment. Apparently forgetting that I'm still here, to check, and that I've no intention of feeding myself to their digestions and submitting myself to their reconstitution, if I can help it. ${ }^{289}$

The most common interpretations of Plath's writings, and of her life, have adopted the dialectic of the male 'villain' and female 'martyr victim' around which a logic of blame and vengeance pivots in her mythopoeia. As Rose puts it:

What we are dealing with is, obviously enough, not Plath herself but her representations, her own writing, together with all the other utterances which have come to crowd it - joining in the conversation, as one might say... Plath's writings and the surrounding voices stand in effigy for her, they speak in her name. $^{290}$

Rose points out that Plath's writings and those of her biographers and critics speak for her to the extent that it has become "impossible to read Plath independently of the frame,

\footnotetext{
289 'The Silent Woman'. 201.

290 'The Haunting of Sylvia Plath'. 2.
} 
the surrounding discourses, through which her writing is presented."291 The "effigy" of Plath that haunted Hughes throughout his adult life draws on her writings but is shaped by a reading of her writings that emerged in the early 1970s, at the time of the second wave of feminism. At this time Plath was primarily understood as a feminist writer who attempted to escape and overcome the patriarchal limits placed on her identity through her writings. Plath's suicide was read as a symptom of the intolerable double standards imposed by a patriarchal society. The feminist reading of Plath reduces Plath's historical identity to that of a feminist martyr. As her antagonist, Hughes embodies all that is wrong with patriarchal culture - he is the "Nazi", the "vampire" and the "jailer" that drove the 'queen bee' struggling for autonomy to her death. Hughes resisted this treatment by scholars and biographers by refusing to speak about his relationship with Plath, and in denying critics and biographers permission to reprint material from her work. These attempts to limit the intrusion into his life only served to fuel the image of him as the controlling tyrant of her poems who was now seen as extending his control of Plath to the posthumous voice of her writings.

When Pollitt described Hughes as "the most notorious literary spouse in history" 292 she indicated how Hughes's identity was understood purely in terms of his relationship to Plath (as "spouse") as she presented him in her writings. The extent of his entanglement in Plath's language is illustrated by the cover blurb to Faber and Faber's $80^{\text {th }}$ Anniversary edition of Ted Hughes: Poems Selected by Simon Armitage (2010) which describes Hughes as "a colossus on the literary landscape" (my italics).

Middlebrook has suggested that, from 1965 onwards, Hughes was "stalled...in a public role he was helpless to defy." According to Middlebrook, the clamour surrounding each publication of Plath's work made Hughes feel as though his family were living in a "mausoleum" with himself on display as the "second-hand relic husband". 293 Hughes became trapped in the mythic drama of Plath's poetry which dictated the way his life and his actions would be constantly picked over and interpreted by others. Hughes's

\footnotetext{
291 'The Haunting of Sylvia Plath'. 69.

292 'Peering into the Bell Jar'.

293 'Her Husband'. 235.
} 
description of himself and his family as being trapped in a "mausoleum" illustrates his notion that he was caught in the discursive trap the queen bee escapes from in 'Wintering' (SPC.215). Indeed, Hughes's struggle to recover his subjective sense of self from the narratives of feminism reflects the reading of Plath as a writer struggling to free her life from the narratives of patriarchy.

In his letter to the Independent following an article by Ronald Hayman, which contained factual errors, Hughes complained: "I hope each of us owns the facts of her or his own life". ${ }^{294}$ In this sense, Birthday Letters can be seen as a way for Hughes to restate the facts of his life. However, the blatant subjectivity in the poems suggests that Hughes's real concern was about how the facts of his life were interpreted. In a letter to the Observer, following the publication and criticism of Stevenson's Bitter Fame, Hughes insisted he had asked Stevenson and her informants to "stick to observed fact, and to make clear at every point that opinion is opinion" and to "avoid interpreting my feelings for me, and to beware how [others] interpreted Sylvia's". ${ }^{295}$ Hughes's letter to Alvarez, following the publication of his Plath memoir contained a similar complaint: "You have supplied details and interpretations in a form that is now being taken as the official text." 296 Pollitt has suggested that Hughes uses Birthday Letters as a corrective narrative to his feminist critics: "Birthday Letters presents itself as an unambiguous rebuke to those who saw Sylvia Plath as Ted victim". ${ }^{297}$ However, in foregrounding his subjectivity, uncertainty, assumptions, and misunderstandings in Birthday Letters, Hughes is not attempting to provide "the truth about Sylvia",298 as Pollitt claims. Rather, his concern is to unsettle the conclusions about his and Plath's lives that are drawn from her writings. As he said in a letter to Stevenson:

\footnotetext{
294 'The Silent Woman'. 8

295 Letter from Ted Hughes to Anne Stevenson reprinted in: 'The Haunting of Sylvia Plath'. 66-7.

296 'The Silent Woman'. 124.

297 'Peering into the Bell Jar'.

298 'Peering into the Bell Jar'.
} 
My simple wish [is] to recapture for myself, if I can, the privacy of my own feelings and conclusions about Sylvia, and to remove them from contamination by anybody else's... ${ }^{299}$

Hughes learned from Plath that a dramatic interpretation of an event is a more persuasive and enduring form of logic than rational argument. A mythic version of events, he learned, is a self-contained form of disclosure that is particularly resistant to contradiction or "contamination" from the discourses that surround it. In Plath's case, on the contrary, the dramatic narrative of her poems orders the additional commentaries around itself like iron filings around a magnet.

In chapter five, we saw that, in Birthday Letters, Hughes dramatises the imaginary aspects of Plath's subjective vision in order to give his mythopoeic reading of the poems and show how the vision of her poems consumed events in their every day life. In this chapter we will be looking at the way Hughes contends with Plath's mythopoeia in order to untangle the story of his life from the subjective vision of Plath and her readers so that he can restate his own feelings and conclusions. By revisiting Plath's drama and assigning different values, meanings and interpretations to her symbols and events, Hughes unsettles their objective status as truth and alerts the reader to the subjectivity of both his and Plath's visions. Without privileging either version of events, Hughes signals to biographers and critics that the truth of these stories can only ever be subjective and provisional; as he says in 'A Visit': "It is only a story. / Your story. My story" (BL.9).

The 'myth' of Hughes and Plath could be said to begin on 25 February 1956, when Hughes met Plath at the party thrown to launch St Boltoph's Review. The day after the party, Plath recorded a dramatic version of their meeting in her Journals:

Then the worst thing happened, that big, dark, hunky boy, the only one there huge enough for me, who had been hunching around over women, and whose name I asked the minute I had come into the room, but no one told me, came over and

299 'The Silent Woman'. 142. 
was looking hard in my eyes and it was Ted Hughes. I started yelling again about his poems and quoting... We shouted as if in a high wind... and I was stamping and he was stamping on the floor, and then he kissed me bang smash on the mouth and ripped my hairband off, my lovely red hairband scarf which has weathered the sun and much love, and whose like I shall never again find, and my favorite silver earrings: hah, I shall keep, he barked. And when he kissed my neck I bit him long and hard on the cheek, and when we came out of the room, blood was running down his face... Such violence, and I can see how women lie down for artists. The one man in the room who was as big as his poems, huge with hulk and dynamic chunks of words; his poems are strong and blasting like a high wind in steel girders. And I screamed in myself, thinking: oh, to give myself crashing, fighting, to you. The one man since I've lived who could blast Richard [Sassoon]. ${ }^{300}$

In this journal entry, Plath depicts Hughes as a kind of brute ("hah, I shall keep, he barked") who is "hunching over women" and eroticises his violence: "he kissed me bang smash on the mouth and ripped my hairband off".

On 27 February, Plath revisited her dramatic characterisation of Hughes in a poem, 'Pursuit', which she described in her Journals as being about "the dark forces of lust". In 'Pursuit', Plath depicts Hughes as a predatory big cat: "There is a panther stalks me down: / One day I'll have my death of him" (SPC.22). Her speaker is "Appalled by secret want" for the "black marauder" of this erotic melodrama and 'hurls her heart' at her pursuer to "halt his pace" (SPC.23). However, the panther remains unsated and demands "a total sacrifice" (SPC.23) and the poem ends with the speaker listening to the panther's approach:

The panther's tread is on the stairs, Coming up and up the stairs.

\footnotetext{
300 'Winter Pollen'. 211-2.
} 
The drama of 'Pursuit', introduces the imaginative power-play between the dominant oppressive male and the passive female victim in many of Plath's poems such as 'Daddy' and 'Purdah' that are taken up and uncritically perpetuated in many of the biographical accounts of Hughes and Plath's relationship.

In the Birthday Letters poem 'Trophies', Hughes revisits 'Pursuit' and reverses the roles cast in Plath's drama to suggest that she is the pursuer and that he was the victim of her fatal appetite. The poem opens with Hughes's retrospective incredulity at her depiction of him as "the panther" before turning this image into a symbol of Plath's tenacious attachments to men:

The panther? It had already dragged you

As if in its jaws, across Europe.

As if trailing between its legs,

Your mouth crying open, or not even crying any more,

Just letting yourself be dragged. Its real prey

Had skipped and escaped. So the fangs,

Blind in frustration,

Crushed your trachea, strangled the sounds. The Rorschach

Splashing of those outpourings stained

Your journal pages.

In his dramatic revision of 'Pursuit', Hughes suggests that he was the 'trophy' in Plath's hunt for a replacement for her "real prey", Richard Sassoon (and presumably ultimately her father), who had "escaped". ${ }^{301}$ Although the younger Hughes, as a character in the drama, believes he is the trophy hunter, the older Hughes recognises the prints of the panther when he reads Plath's journal pages that are stained with "the Rorschach splashing of [her] outpourings". Hughes is referring here to the journal entries Plath

${ }^{301}$ The chronological inaccuracy of Hughes's rhetoric is indicative of the fictive terms of his drama and his desire to challenge interpretation rather than fact. Plath and Hughes met at St Boltoph's on 25 February 1956. Plath went to Paris to 'hunt' for Richard Sassoon 24 March 1956, which suggests, like her journal entries that, despite her own dramatic portrait of Hughes, Plath still felt helplessly in love with Richard Sassoon after her meeting with Hughes at St Boltoph's. 
wrote after Richard Sassoon wrote to her from France to terminate their relationship, leading to her futile search for him in Paris. Plath received Sassoon's letter on 6 March 1956, ten days after meeting Hughes at the St Boltoph's party. In her Journals she wrote page after page expressing her agony at his 'abandonment':

I hoped in a night of terror that I was not bound to you with that irrevocable love, for ever. I fought and fought to free myself as from the weight of a name that could be a baby or could be a malignant tumour; I knew not. I only feared. But although I have gone crying (god, have I) and battering my head against spikes, desperately thinking that if I were dying, and called, you might come, I have found that which I most feared, out of my weakness. I have found that it is beyond your power ever ever to free me or give me back my soul. You could have a dozen mistresses and a dozen languages and a dozen countries, and I could kick and kick; I would still not be free. ${ }^{302}$

In 'Trophies', Hughes describes reading Plath's journal and, like the speaker in Plath's poem 'Pursuit' who is "appalled by secret want" (SPC.22) Hughes describes the thrill of being targeted and pursued by Plath's predatory appetite:

\section{After forty years}

The whiff of that beast, off the dry pages,

Lifts the hair on the back of my hands.

The thrill of it. The sudden

Look that locked on me

Through your amber jewels

And as I caught you lolling locked

Its jaws on my face.

302 'The Journals'. 218. 
In Plath's account of her first meeting with Hughes in her Journals, she described biting Hughes "long and hard on the cheek" and in 'Trophies' this incident is used dramatically to emphasise Hughes's role as the victim of Plath's attack:

\section{With a laugh I}

Took its full weight. Little did I know

The shock attack of a big predator

According to survivors numbs the target

Into drunken euphoria. Still smiling

As it carried me off I detached

The hairband carefully from between its teeth

And a ring from its ear, for my trophies.

Looking back, Hughes recalls his younger self walking away from the party with Plath's hairband and earring under the delusion that he was the trophy hunter. In his "drunken euphoria" he is not yet aware yet that he had been marked down as a target and future victim of Plath's "great love” (BL.178).

In her Journals, Plath described the strong emotional elements of her experiences, which seemed to control her entire character and life: "It is as if my life were magically run by two electric currents: joyous positive and despairing negative - which ever is running at the moment dominates my life, floods it." ${ }^{303}$ In Birthday Letters, this emotional intensity informs Plath's interpretation of events and their subsequent representation. Throughout Birthday Letters, Hughes characterises Plath as having a tendency to over-react and over-dramatise commonplace events. In several poems, Hughes revisits biographical events to illustrate the gap between the event and its representation in her writings. In this way, he unsettles the reader's confidence in the objectivity of Plath's perceptions and conclusions.

303 'The Journals'. 395. 
In 'Fever', for example, Hughes describes a bout of fever Plath suffered during their honeymoon in Spain and links it to the drama in her poem 'Fever $103^{\circ}, 304$ In Plath's poem, the fever is a period of fiery self-annihilation that leads to rebirth. The speaker is described as burning in "the tongues of hell" for "Three days [and] Three nights" (SPC.232), a period that, as we have seen, in Plath's mythic system, precedes her rebirth. Consequently, in the final section of 'Fever $103^{\circ}$ ', the speaker transcends her suffering through a fiery transformation. In this dissolution of self, Plath's 'heroine' achieves a form of purity that enables her to escape her painful attachments (to men) and achieves a pure form of existence that is untainted by desire (as in 'Tulips').

However, Hughes's response to 'Fever $103^{\circ}$ ' removes the event from Plath's mythic system to expose her mythopoeia and over-dramatisation of events (he does the same in 'The Rabbit Catcher'). Rather than emphasising Plath's suffering, in 'Fever', Hughes describes her sickness in deliberately unaffected terms: "You had a fever. You had a real ailment. / You had eaten a baddie" (BL.46). He casts himself in the role of Plath's assistant, or nursemaid: "I bustled about / I was nursemaid. I fancied myself at that" (BL.46). In 'Fever 103', the soup the speaker is given makes her "retch" (SPC.232) but in Hughes's 'Fever', the soup is the restorative that will end her suffering:

I made a huge soup

Carrots, tomatoes, peppers and onions, A rainbow stir of steaming elixir. You Had become a sluice, a conduit Of pure vitamin C. I promised you This had saved Voltaire from the plague...

I spooned it Into your helpless, baby-bird gape, gently,

\footnotetext{
${ }^{304}$ Again, Hughes is more concerned with challenging the representation of an event than the autobiographical facts. Although Plath did suffer from a fever in Spain on 25 August 1956, the date of composition for 'Fever $103^{\circ}$ ' (20 October 1962) suggests that Plath's poem was inspired by a " $103^{\circ}$ milk fever" she had in England and describes in her journal entry of 16 May 1962. 'The Journals'. 648.
} 
Masterfully, patiently, hour by hour.

I wiped your tear-ruined face, your exhausted face,

All loose with woe and abandon.

I spooned more and you gulped it like life,

Sobbing 'I'm going to die.'

Hughes interprets Plath's "woe and abandon" as an over-reaction to her symptoms and he refuses to collude with what he sees as her unnecessary dramatisation of her sickness:

\section{As I paused}

Between your mouthfuls, I stared at the readings

On your dials. Your cry jammed so hard

Over into the red of catastrophe

Left no space for worse. And I thought

How sick is she? Is she exaggerating?

And I recoiled, just a little,

Just for balance, just for symmetry, Into sceptical patience, a little.

In 'Fever', Hughes turns Plath's drama of transcendence into drama that emphasises Plath's tendency to exaggerate the severity of her suffering (to dramatise), and over-react to situations (an assertion Hughes also makes in 'Fate Playing', 'The Fifty-Ninth Bear', 'Ouija', 'The Bird', 'The Minotaur', 'The Rabbit Catcher; and 'Child's Park'). Plath's habit of "crying wolf", explains, to Hughes, his difficulty in understanding the severity of her symptoms when, in 1963, she was really suffering. Hughes closes the poem with a brief summary of the roles he assigns to himself and Plath in his version of events in Birthday Letters:

You were overloaded. I said nothing. I said nothing. The stone man made soup. 
The burning woman drank it.

The "stone man" and "burning woman" of Birthday Letters are an ironic echo of the roles Plath assigns to Hughes and herself in her own drama. Hughes twice repeats that he "said nothing" to emphasise his retrospective regret at not appearing more sympathetic to Plath. However, the drama of the poem helps Hughes explain why he saw his undemonstrative response to Plath's ailment as a necessary counter balance to her behaviour at the time.

The "stone man" and the "burning woman" of 'Fever' appear elsewhere in Birthday Letters, where Hughes takes the role of Plath's bungling helper and carer. In 'The Blackbird' he is Plath's "nurse and... protector" (BL.162), in 'Moonwalk' he is "The doctor who humours, and watches / As the patient dies in his care" (BL.41) and in 'The Shot', he laments his mishandling of the burning woman's situation:

In my position, the right witchdoctor

Might have caught you in flight with his bare hands

Tossing you, cooling, one hand to the other, Godless, happy, quieted.

\section{I managed}

A wisp of your hair, your ring, your watch, your nightgown.

(BL.17)

In assigning himself and Plath these roles in Birthday Letters, Hughes restates the dramatic roles of 'Lady Lazarus' in which the male ("Herr Doktor") is one of the indifferent spectators ("The peanut-crunching crowd / Shoves in to see" (SPC.245)) as the burning woman "melts to a shriek" (SPC.246). In his revision of this power dialectic, the relationship between "Herr Doktor" and the "burning woman" disturbs the reader because the burning woman's suffering is a performance rather than because it is a spectacle. 
Plath is characterised as a 'performer' in a number of Birthday Letters poems such as 'Chaucer', in which she declaims to a group of mesmerised cows and becomes, in turn, mesmerised by their attentiveness:

You just could not believe it.

And you could not stop. What would happen

If you were to stop? Would they attack you,

Scared of the silence, or wanting more - ?

So you had to go on. You went on -

And twenty cows stayed with you hypnotized.

If Hughes intended this group of cows to stand for what he saw as Plath's largely posthumous, spellbound but uncomprehending, audience, this would explain the "awed six feet of reverence" (BL.51) they keep during her recital.

In 'God Help the Wolf after Whom the Dogs Do Not Bark', Hughes suggests that Plath's compulsion to perform is a pattern of behaviour established in her early childhood. Her feelings of guilt over her father's death, and feelings of obligation to her self-sacrificing mother's, provoke her into offering gifts of herself to earn approval and acceptance, and to earn the reciprocation of her love:

You tried your utmost to reach and touch those people

With gifts of yourself -

Just like your first words as a toddler

When you rushed at every visitor to the house

Clasping their legs and crying: 'I love you! I love you!'

Just as you danced for your father

In the home of anger - gifts of your life

To sweeten his slow death and mix yourself in it

Where he lay propped on the couch,

To sugar the bitterness of his raging death.

(BL.26) 
In 'God Help the Wolf after Whom the Dogs Do Not Bark', Hughes suggests that, as an eight-year-old, Plath danced for her father to "sugar the bitterness of his raging death" (Otto died from complications following his untreated diabetes). As an adult, this performing behaviour becomes a ritual she must 'repeat all over again' throughout Birthday Letters:

You searched for yourself to go on giving it As if after the nightfall of his going You danced on in the dark house, Eight years old, in your tinsel.

According to Hughes, Plath's need for acknowledgement and for reciprocation for her 'gifts of herself' provoked negative reactions from some of those around her. "Nobody wanted your dance" (BL.27), he comments, which she interpreted as a reflection of her own failings.

Hughes's role as Plath's carer in Birthday Letters means he must protect her from the 'derision and mud' cast at her efforts and to encourage her to persist in her writing. In 'The Literary Life', Hughes recalls how, after he and Plath visited Marianne Moore in her Brooklyn home, Plath forwarded her some carbon copies of her poems. As Plath records in her Journals, Moore returned the poems with "a queerly ambiguous spiteful letter" advising her "don't be so grisly" and commenting: "I only brush away the flies". ${ }^{305}$ Moore also made a pointed comment about "typing being a bugbear" in reference to the fact that Plath had sent her carbon copies, adding: "I shall not engross them" (BL.75) with any comments. According to Hughes, Plath was devastated by Moore's letter and in his role as the burning woman's carer and protector, he describes attempting to help Plath recover from this tragedy:

I took the point of that 'engross'

305 ‘The Journals'. 406. 
Precisely, like a bristle of glass

Snapped off deep in my thumb.

You wept

And hurled yourself down a floor or two

Further from the Empyrean.

I carried you back up.

(BL.75)

In 'Blood and Innocence', Hughes suggests that Plath's compulsion to give "“gifts of [her] life" is sublimated into her writing, which she offers to her audience. Plath's use of her most terrifying and disturbing experiences in Ariel becomes part of her wider performance to demonstrate the authenticity and depth of her feeling and to obtain acknowledgement and acceptance from others. In 'Blood and Innocence' Hughes portrays Plath offering her audience an account of her electro-convulsive treatment to obtain their acknowledgement. The poem situates Plath in a metaphysical theatre that is “in the wilderness" as in her poem, 'The Hanging Man', in which the speaker describes herself as being "like a desert prophet" (SPC.141):

In the wilderness

Between the locusts and the honey

They demanded it. Oh, no problem.

If that's all you want,

You said, and you gave it.

Your electrocution, with all its zigzags.

Hughes describes Plath's smile as being "slightly tense" (BL.168) as she offers this experience to her audience, which offers a dramatic image of the electro-convulsive treatment itself, galvanising her features, and her discomfort in revisiting this shattering experience. Hughes describes Plath's audience contemptuously as "Waving their feelers" as they tug away her gifts "down their tunnels" (BL.168) before returning to demand more. In the final stanzas, Plath's audience demand her childhood grief relating to her father's death and she obligingly wheels her father out for their entertainment: 
Oh, no problem,

Why on earth didn't you say.

Daddy unearthed. And the nine-year-old howl

Come of age

Round his good ankle, a cart-rope -

Hauling him into the light.

Having dragged him "into the light”, Plath does "a hammer-dance on Daddy's body" and asks her audience, "How is that, / Is that OK?" (BL.169) looking around expectantly for applause, Plath finds herself alone in the empty theatre, surrounded only by the ghosts she has invoked:

You looked around for some acknowledgement

From the demanding mouths

In a gilded theatre suddenly empty

Of all but the faces

The faces faces faces faces

Of Mummy Daddy Mummy Daddy -

Daddy Daddy Daddy Daddy

Mummy Mummy

The absence of punctuation in the final lines of 'Blood and Innocence' pushes the reader forward, as though in panic, towards the poem's dreadful concluding isolation.

In depicting Plath's art as performance, Hughes is not suggesting that the feelings expressed in Plath's poems are inauthentic. They are authentic in terms of Plath's subjective experiences and are an image of the "passionate character", of the "temper", 
and "unique blend of courage and vulnerability" ${ }^{306}$ Hughes referred to in describing Plath in his introduction to her Journals. In Birthday Letters, this "passionate character" provides an unusual resource of ecstasy, distress, or rage that can be triggered in the most unexpected circumstances.

The Birthday Letters poem 'Child's Park' relates to an incident recorded in Plath's Journals in 1958. In her Journals, Plath records how she and Hughes had decided to walk through Child's Park and how she had taken a pair of scissors in her pocket to cut a rose from the rose garden "yellow, if possible". As they walked through the park they encountered three girls 'stealing' "mountains" of rhododendrons, which drove Plath into a fury:

We came up slowly with evil eyes. I felt a blood-lust - sassy girls, three of them "O here's a big one", a girl ostentatiously said. "Why are you picking them?" Ted asked. "For a dance. We need them for a dance." They half-thought we would approve. "Don't you think you'd better stop?" Ted asked, "this is a public park." Then the little one got brassy \& fairly sneered "This isn't your park." "Nor yours," I retorted, wanting strangely to claw off her raincoat, smack her face, read the emblem of her school on her jersey \& send her to jail. "You might as well pull up the bush by its roots." She glared at me \& and I gave her a mad wild still stony glare that snuffed hers out... I have a violence in me that is as hot as deathblood. I can kill myself or - I know it now - even kill another. I could kill a woman or wound a man. I think I could. I gritted to control my hands, but had a flash of bloody stars in my head as I stared that sassy girl down, and a blood longing to fly at her and tear her to bloody beating bits. ${ }^{307}$

Plath provided another, more measured, version of the incident in her poem 'The Fable of the Rhododendron Stealers', in which she compares her "petty thievery" with their "large” as a kind of moral lesson. In Hughes's responding poem, 'Child's Park', he re-

\footnotetext{
306 'Winter Pollen'. 182.

307 'The Journals'. 394-5.
} 
dramatises the event described in Plath's Journals through the dialectic of "the stone man" and "the burning woman" in his earlier poem 'Fever', describing himself as "stepping back" from the glare of her conflagration:

You imagined a veil-rending defloration

And a rebirth out of the sun - mixed up together

And somehow the same. You were fearless

To meet your father,

His Word fulfilled, there, in the nuclear core.

What happens in the heart simply happens.

I stepped back. That glare

Flinging your old selves off like underthings

Left your whole Eden radioactive.

In 'Child's Park', the fiery purification and rebirth of Plath's 'Fever $103^{\circ}$ ' becomes a self-destructive conflagration of fury. Hughes changes the rhododendrons to azaleas, connecting them to Plath's mother and father (as in 'Electra on Azalea Path') as "the brands / Of [her] own burning" (BL.69). The "nuclear" temperament behind Plath's creative rebirth is not only self-destructive but poisons everything around her. The line in the centre of the stanza, "what happens in the heart simply happens", is ambiguously disconnected from the other stanzas implying that the growing distance between Hughes and Plath's subjective experiences was becoming necessary for their mutual growth and self-preservation.

Plath appears again as the burning woman in 'The Minotaur', in which Hughes describes her destroying an "heirloom" mahogany table-top with a high-stool because he is "twenty minutes late for baby-minding" (BL.120). His response to the incident is, again, as the stone man, to calmly suggest she channel these energies into her poems creatively (presumably as an act of catharsis): 
'Marvellous!' I shouted, 'Go on

Smash it into kindling,

That's the stuff you're keeping out of your poems!'

And later, more considered and calmer

'Get that shoulder under your stanzas

And we'll be away.'

(BL.120)

Throughout Birthday Letters, Hughes re-stages the drama in Plath's poems to appeal to the reader, as he does to Plath, for balance and for symmetry, suggesting that the drama and emotional content of Plath's poems (for example her Holocaust imagery) is not necessarily symptomatic of, or commensurate with, her ill treatment by others. By presenting Plath as a performer, Hughes unsettles the reading of Plath's suffering in her poems as a result of her ill-treatment at the hands of others, and unsettles the reading of her suicide as the desperate act of a feminist martyr.

In 'Sam', Hughes unsettles the suggestion that Plath was his victim by pointing out that her suicide can be understood as an act of violence directed at him. This poem recalls Plath's 1958 poem 'Whiteness I Remember', which she based on another biographical incident. In Plath's poem she describes hiring a "humdrum, unexceptional" white horse called Sam, whose "tired sobriety" meant he was considered suitable for novice riders. However, during the ride, the horse suddenly bolts:

Then for ill will

Or to try me he suddenly set

Green grass streaming, houses a river

Of pale fronts, straw thatchings, the hard road

An anvil, hooves four hammers to jolt

Me off into their space of beating,

Stirrups undone and decorum.

(SPC.102-3) 
When Sam bolts, Plath loses her footing in her stirrups and falls from the saddle, to hang on perilously beneath the horse's neck. She describes her determination to survive 'simplifying her' for the duration of the ride:

\section{Resoluteness}

Simplified me: a rider, riding

Hung out over hazard, over hooves

Loud on earth's bedrock. Almost thrown, not

Thrown: fear, wisdom, at one: all colours

Spinning to still in his one whiteness.

(SPC.103)

'Whiteness I Remember' is an interesting poem in the way it anticipates Plath's later riding poems, such as 'Ariel', where the horse and rider are simplified by the motion of the galloping horse again becoming "at one with the drive" (SPC.240). In Plath's last riding poem, 'Sheep in Fog', which she completed in February 1963, and which Hughes described as the elegy for Ariel, "the hills step off into whiteness" (SPC.262). Similarly, in her late 1963 poem 'Words', Plath describes words as "Echoes traveling / Off from the centre like horses" and as "The indefatigable hoof-taps" (SPC.270).

In 'Sam', Hughes revisits the "indefatigable hoof-taps" of Plath's 'Whiteness I Remember'. Like Plath, he dramatises the runaway horse ride and focuses on her determination to survive. However, in 'Sam', Hughes focuses on Plath's resoluteness to live in order to question how this determination vanished only a few years later. He suggests, as he does in his critical essays, that perhaps her poems were "'selfish with her resources" ${ }^{, 308}$ and saved her in order to be written:

When I jumped a fence you strangled me

One giddy moment, then fell off,

Flung yourself off and under my feet to trip me

308 'Winter Pollen'. 181. 
'Sam' appears early in Birthday Letters, so the abrupt entry of Plath's suicide into the narrative, juxtaposed against an event of 1958, creates a chronological jarring that removes the reader's retrospective anticipation of Plath's suicide to dramatise the brutal suddenness with which Hughes experienced it. In describing Plath as having thrown herself under his feet to trip him, and tripping him, Hughes provides a dramatic image of his wife's suicide as an act of violence directed against him.

Throughout Birthday Letters, Hughes suggests that Plath injures herself in attacking others. In 'Trophies' when Hughes looks at the tortured introspection of her journal pages he notes: "Plainly the blood / Was your own" (BL.18). Similarly, in "The Tender Place', Hughes describes the words in Plath's late poems as "Holding in their entrails" (BL.13). In 'The Cast', Hughes revisits the ritual execution of himself and Otto Plath in 'Daddy'. In Plath's poem the speaker says, “There's a stake in your fat black heart" (SPC.224) but in 'The Cast', 'Daddy' is tied to a stake is in the town square, like St Sebastian, and shot full of the arrows from her "immortal poesy":

\section{Helpless,}

As weightless, voiceless as lifeless,

He had to hear it all

Driven into him up to the feathers,

Had to stand the stake

Not through his heart, but upright

In the town square, him tied to it

Stark naked full of those arrows

In the bronze of immortal poesy.

(BL.179)

Although Hughes does not depict himself as the victim of Plath's violence in 'The Cast', he is presumably conflated with Plath's 'Daddy' here (as “the vampire who said he was you" (SPC.224)) as he is in other of the Birthday Letters poems that revisit Plath's 
subjective drama. In his revision of the ritual murder in Plath's 'Daddy', he emphasises the public humiliation of the attacks in Plath's poems. However, the real victim of Plath's 'Daddy', is herself. Hughes describes the ritual exorcism of her father's hold on her as being like removing a piece of "shrapnel" from her "wound" (BL.179) that in curing her also kills her:

Healed you vanished

From the monumental

Immortal form

Of your injury: your Daddy's

Body full of your arrows. Though it was

Your blood that dried on him.

In describing "the monumental / Immortal form of [Plath's] injury" Hughes hints at the impact of Plath's poems on those left to deal with accusations in her writings. Her suicide prevented Hughes and her mother Aurelia from obtaining forgiveness or from ever achieving redemption, and they were forced to play the roles allotted in Plath's myth for the rest of their lives.

Throughout Birthday Letters, Hughes describes his posthumous relationship with Plath as a kind of imprisonment from which he cannot escape. He draws the metaphor of imprisonment from Plath's poem 'The Jailer', (a poem Hughes removed from his 1965 version of Ariel but later published in her Collected Poems). In 'The Jailer', Hughes is cast as "The rattler of keys" (SPC.226) a brutal tyrant who entraps, controls, and even tortures the poem's speaker, who complains "I have been drugged and raped... / Hung, starved, burned, hooked" (SPC. 226-7). Hughes contends with Plath's rhetoric by reversing its drama. In 'Drawing', Hughes describes Plath's art as the 'jailer' of objective reality; it is the prison in which she captures and punishes those around her for their offences: "You drew doggedly on, arresting details / Till you had the whole scene 
imprisoned" (BL.44). ${ }^{309}$ Similarly, in 'The Blackbird' Hughes depicts Plath as the jailer of her Ariel voice:

You were the jailer of your murderer -

Which imprisoned you.

And since I was your nurse and your protector

Your sentence was mine too.

In suggesting that Plath was "the jailer of [her] murderer" Hughes acquits himself of any responsibility for her final act by reminding the reader that her death was actually suicide.

In 'The Blackbird', Hughes also suggests that Plath's murderer was the Ariel voice. Adopting the imagery from Plath's 'The Jailer' to describe the "gestation" period of the Ariel voice as a term of imprisonment: "You fed your prisoner's rage, in the dungeon / Through the keyhole" (BL.162). When the Ariel-voice finally escapes from its dungeon, the world lays open like an empty page onto which the Ariel voice writes the 'story' of its imprisonment:

The lawn lay like the pristine waiting page

Of a prison report.

Who would write what upon it

I never gave a thought.

In 'The Ventriloquist', the Ariel Voice's "prison report" is an outraged demand for justice after Hughes's betrayal. Hughes describes Plath as a ventriloquist and the Ariel-voice as her doll, perhaps the "living doll" of 'The Applicant' (SPC.221) or the “jewelled / Doll” of 'Purdah' (SPC.244). In 'The Ventriloquist', Hughes describes how the Ariel voice takes over Plath's identity and stands in as her posthumous simulacrum. In the drama of the poem, after having "killed" Plath the ventriloquist, the doll stands on the roof, "Screaming to the stars to look / And see justice done" (BL.181). In this poem,

${ }^{309}$ In '18 Rugby Street', Plath's nose is described as “the jailor of [her] vanity” (BL.23). 
as in the others we have considered, Hughes conflates the violence Plath directed at those around her with the violence she commits upon herself.

In 'Brasilia', Hughes adopts the imagery of the futuristic steel super-humans in Plath's poem of the same title ("These people with torsos of steel / Winged elbows and eyeholes... / These super-people!" (SPC. 258)) to describe another version of the posthumous 'effigy' of Plath that returns in the invulnerable form of her Ariel poems, to act as judge, jury, and executioner of those who have failed her. Plath's court, the public arena of her writings, where Hughes and Plath's parents are judged and punished for the amusement of her peanut crunching onlookers, appear as a kind of amphitheatre:

You returned

In your steel helm. Helpless

We were dragged into court, your arena,

Gagged in the hush.

Titterings of horror

And the bead of sweat in the spine's furrow.

You delivered

The three sentences. Not a whisper

In the hush.

Your great love had spoken.

Only the most horrible crime

Could have brought down

The blade of lightning

That descended then. Dazzled,

All coughed in the ozone.

Even the dogs were stunned. And the same flash

Snatched you up into Heaven.

(BL.178) 
The "blade of lightning" recalls Plath's electro-convulsive treatment, which as we have seen, is a symbol of her resurrection in her mythopoeia. ${ }^{310}$ Here, however, Plath's posthumous resurrection involves a public execution of Hughes, Aurelia Plath and Otto Plath, as Plath is "snatched up to heaven" in the martyrdom that ensures her victims guilt.. Plath's supporters, her "Colosseum flunkys" (BL.178), ${ }^{311}$ carry the victims' dismembered remains out of the arena. The dramatic public execution in 'Brasilia' recalls Hughes's 1988 letter to Stevenson in which he described his reluctance to speak of Plath and "be dragged out into the bull-ring and teased and pricked and goaded into vomiting up every detail of my life with Sylvia for the higher entertainment of the hundred thousand Eng Lit Profs and graduates who - as you know - feel very little in this case beyond curiosity of a quite low order, the ordinary village kind, popular bloodsport kind". 312

The super-human effigy of Plath Hughes describes in 'Brasilia' like the "doll" of "The Ventriloquist' is the implacable 'effigy' of immortal grief and vengeance that lives on in Plath's writings, and in the writings about her:

Every day since, throughout your Empire,

Like the motherly wraith who nightly

Wailed through the streets of Tenochtitlán

Just before Cortés ended it -

Your effigies cry out on their plinths,

Dry eyed. Your portraits, tearlessly,

Weep in the books.

As we have seen, throughout Birthday Letters Hughes describes himself and the characters as playing roles, of being trapped in a myth that has arisen, phoenix-like, from

\footnotetext{
${ }^{310}$ In 'The Badlands' Hughes comments, "Lightning / Had ripped your clothes off / And signed your cheekbone.” (BL.82) In 'The Rag Rug' he says, 'Played on by lightnings / You needed an earth.' (Bl.135). In 'The Tender Place', in his description of the electro-convulsive treatment he states: "lightning rods wept copper / And the nerve threw off its skin / like a burning child" (BL.12).

${ }^{311}$ A pun on The Colossus.

${ }^{312}$ Letter from Ted Hughes to Anne Stevenson reprinted in: 'Ariel's Gift'. 10.
} 
Plath's writings and the discourses that surround them. By revisiting and revising Plath's rhetorical metaphors, Hughes attempts to re-write his story and his role within the story that has haunted him all his life. However, in telling his own story, Hughes does not limit himself to the symbols and drama and stories that appear in Plath's writings. Birthday Letters draws on a range of literary works, ancient myths, and folk tales in order to both create and unsettle meaning.

In his essays, Hughes pointed out that Plath's use of myth is not 'literary', she does not 'add' myths to her poems as an aesthetic touch; the myths suggest themselves to her imagination as part of the creative act and are a record of her imagination's workings. The same can be said of Hughes's use of stories in Birthday Letters, and in his conception of the function of poetry, as Sagar has pointed out:

The purpose of all serious poetry is to find a shape and meaning in the chaos of experience. For the whole of his career Hughes sought appropriate myths, or adaptations or amalgamations of myths, to help him in his effort to place his own little life in the context of permanent or recurrent experience in a world larger than the merely human. ${ }^{313}$

In Birthday Letters, Hughes's use of other stories is a means of ordering the "chaos" of his own feelings and conclusions concerning his relationship, and posthumous relationship, with Plath. In 'Fulbright Scholars', for example, when Hughes describes himself eating a peach for the first time to contrast his youthful recklessness against the timid inaction of T.S. Eliot's Prufrock. Wagner and Middlebrook have suggested that this incident echoes the Old Testament story of Adam biting into the apple of knowledge, and in the fifties the expression "peach" was often used to describe an attractive woman. In 'A Picture of Otto', Hughes describes an imaginary meeting with Otto Plath in hell through the dramatic terms of Wilfred Owen's 'Strange Meeting'. In doing so, he sets up the conciliatory theme of this poem in which he makes peace with his German enemy, the ghostly rival who he has fought with for possession of Plath throughout the Birthday

313 'The Laughter of Foxes'. 83. 
Letters poems. All the characters in Birthday Letters are trapped in various stories. This is both a result of the way that they present and understand themselves and how they are perceived by others.

In 'Dreamers', Hughes describes Assia Wevill by imagining Plath's subjective perception of her. Plath's perceptions are largely drawn from what she has learned of Assia's story. Assia was a World War Two refugee, her German mother and her KievJewish father were married in Berlin on 5 May 1927, just ten days before Assia's birth, and only a few years before the Nazis came to power in Germany. Assia's father, Lonya Gutmann, was particularly vulnerable to the Nazis as being Jewish and having married a German woman he posed a direct threat to the Deutschen Blutsverband (German blood union). Assia's family were part of a first wave of Jewish emigration from Germany that included 25,000 other Jews within three months. They arrived in Pisa, Italy, by train in 1933, just days after Assia's sixth birthday. In A Lover of Unreason, Koren and Negev point out that Assia's father was "a born storyteller [who]...often mixed fact with fiction to amaze his audience and create an aura of intrigue around himself. He thus told [Lucas] Myers that he "had once been physician to the Bolshoi Ballet" 314 This story, true or false, finds its way into 'Dreamers' and affects Hughes's and Plath's imaginative perceptions of Assia's background, as do her own stories about fleeing Nazi Germany. Koren and Negev have suggested that Assia, like her father, was also a story-teller and would occasionally embellish facts in order to dramatize her story. Although she was barely six years old when her parents took her to Pisa, she was able to tell a variety of versions of her escape:

In later years, Assia's tales of flight from Germany portrayed an ordeal. Lucas Myers recounts her stories, of how the whole family narrowly escaped internment. 'Assia described hiding in a railway compartment and listening to the tramp of Nazi guards coming down the corridor.' The poet Philip Hobsbaum, like several of Assia's friends, remembers that she had been shunted about in various

\footnotetext{
${ }^{314}$ Koren, Yehuda and Negev, Eilat. A Lover of Unreason: The Life and Tragic Death of Assia Wevill. London: Robson Books, 2006. 3. Hereafter referred to as 'A Lover of Unreason'.
} 
displaced persons' camps and suffered semi-starvation and dirt, 'But I'm inclined to think she embroidered or even fantasised it,' he has said. ${ }^{315}$

That the poem 'Dreamers' may contain inaccuracies on a factual level is irrelevant to the subjective drama Hughes offers in Birthday Letters. Many of the stories we live by are embellished in some way, or serve some projection of ideal self that affects how we are understood by others, or understand ourselves. As we have seen, the poems in Birthday Letters are a record of subjective experiences, both Hughes's and Plath's (as he understands her experience). When, in 'Dreamers', Hughes describes his and Plath's meeting Assia, he attempts to adopt Plath's subjective impressions and describe Assia through the stories they associate with this woman.

Hughes describes Plath being "fascinated" by their new exotic acquaintance and "The Fable she carried" which "Requisitioned you and me and her / [as] Puppets for its performance" (BL.157). Indeed, Assia's background would appear, slightly modified, in Plath's 'Daddy', where Plath played Assia's role as the child of a German-Jew mixedmarriage and Hughes was cast as the Nazi father and lover. Assia is also fascinating to Plath because she is imaginatively linked to the German folk tales she was read as a child. It is as though Plath has already encountered Assia's "ancestral Black Forest whisper" (BL.157) in her dreams. The stories associated with Assia combine in Plath's imagination to produce new stories, but also correspond with aspects of Plath's inner self, as though Assia were another aspect or image of herself. On another level, Hughes's and Plath's meeting with Assia changes their biographical story and suddenly they find themselves in a new "Fable" that "requisitions" them both imaginatively and, in Hughes's case, romantically.

Hughes is "requisitioned" by another story in 'Life After Death', in which he describes the grief he and Plath's children suffer in the aftermath of Plath's death. Initially, this grief is not a palpable material that can be managed or organised, it is formless and senseless:

315 'A Lover of Unreason'. 7-8. 
Day by day [Nicholas's] sister grew

Paler with the wound

She could not see or touch or feel, as I dressed it

Each day with her blue Breton jacket.

In 'Life After Death', Hughes suggests that his and the children's grief needs a story in order to tell its tale, and Hughes finds one as he lies awake in bed at night and hears the wolves at London Zoo howling at the moon:

Dropped from life

We three made a deep silence

In our separate cots.

We were comforted by wolves.

Under that February moon and the moon of March

The Zoo had come close.

And in spite of the city

Wolves consoled us. Two or three times each night

For minutes on end

They sang. They had found where we lay.

And the dingos, and the Brazilian-maned wolves -

All lifted their voices together

With the grey Northern pack.

The wolves lifted us in their long voices.

They wound us and enmeshed us

In their wailing for you, their mourning for us,

They wove us into their voices. We lay in your death,

In the fallen snow, under falling snow, 
As my body sank into the folk-tale

Where the wolves are singing in the forest

For two babes, who have turned, in their sleep,

Into orphans

Beside the corpse of their mother.

The story that occurs to Hughes is, of course, the Roman myth of Romulus and Remus who are exposed in the wilderness only to be suckled by a she-wolf. The howling of the wolves combines with this myth in Hughes's imagination and re-appears in his poem 'The Howling of Wolves' in Wodwo (1967), the first book of poems he released after Plath's death. In 'The Howling of Wolves' the speaker describes listening to the wolves' cries and being unable to make sense of their grief. "What are they dragging up and out on their long leashes of sound" (THC.180) the speaker asks, before hearing the "crying of a baby, in this forest of starving silences" (THC.180). The crying of the wolves, like the crying of Plath's children, has no meaning for them "the wolf is small, [and] comprehends little" (THC.180). Like the child, the wolf does not know why it suffers, it cannot make sense of its agony and only knows it is unconsciously compelled to go on living in this senseless way: "It must feed its fur" (THC.181). In 'Life After Death', Hughes echoes the images of this earlier poem as he describes feeding his baby, Nicholas, in a high-chair:

Your son's eyes, which had unsettled us

With your Slavic Asiatic

Epicanthic fold, but would become

So perfectly your eyes,

Became wet jewels,

The hardest substance of the purest pain

As I fed him in his high white chair.

Great hands of grief were wringing and wringing

His wet cloth of face. They wrung out his tears.

But his mouth betrayed you - it accepted 
The spoon in my disembodied hand

That reached through from the life that had survived you.

Like the wolf that "must feed its fur"; Hughes, Nicholas, and his sister must go on living in the meaningless "wilderness" after the loss of their mother. The poem provides a dramatic image of the grief, guilt and bewilderment that Hughes and the children experienced following Plath's suicide. As I have already said, this is an aspect of Hughes's story that has been conspicuously absent from the discourses that have perpetuated the Plath myth.

As a work of the imagination, Birthday Letters is naturally a story made out of other stories that intrude on the narrative to provide a dramatic image of the way the characters are making sense of events. In 'A Pink Wool Knitted Dress', for example, as we have seen, the newly-married Plath imagines her wedding in the magical terms of Caliban's dream in The Tempest (Act 3, Scene 2):

You said you saw the heavens open

And show riches, ready to drop upon us.

Levitated beside you, I stood subjected

To a strange tense: the spellbound future.

Hughes, on the other hand, adopts folk-tale stock imagery to describe what he imagines was Aurelia Plath's disappointment at her daughter's choice of husband:

I was a post-war, utility son-in-law!

Not quite the Frog-Prince. Maybe the Swineherd ${ }^{316}$

Stealing this daughter's pedigree dreams

From under her watchtowered searchlit future.

\footnotetext{
${ }^{316}$ In The White Goddess, Robert Graves suggests that the early priests of the Goddess were swineherds as the Goddess was associated with the sow, with her crescent tusks, who eats her young.
} 
In 'Myth and Education', Hughes argued that great stories survive because they contain healing symbols and drama that help us to reconcile our inner and outer worlds, and in Birthday Letters, as in his wider critical writings, Hughes suggests that in order to know someone, we need to know their story. ${ }^{317}$ In 'The Bird', Hughes uses the fairy tale of 'Rapunzel' to describe the imprisonment of Plath's inner-voice, hidden away from her conscious self. In the terms of the fairy tale of Rapunzel, Plath's true voice becomes the princess trapped in a tower with no stairs, awaiting the 'hero' who will release her: ("The princess / Let her hair right down to the ground / From her solitary high window" (BL.77). Hughes casts himself as the hero who hears Rapunzel's voice as she sings in her tower. When he scales the tower to release her, he meets the terrible witch (a folkversion of the White Goddess) and only then, faced with the Ariel voice does Hughes learn the fairy story he is in: "You told me / Everything but the fairy tale" (BL.77). In the fairy tale of Rapunzel, after meeting the witch at the high window, the hero leaps from the tower and lands among thorn bushes below which blind him, and therefore he is never able to see the princess again, who is also cast out of the tower. However, in the story's dénouement, the hero finds Rapunzel again after overhearing her singing and recognising her voice. Thus Hughes re-appropriates the fairy-tale of Rapunzel as an appropriate metaphor for his actions that led to the release of Ariel, and for Plath's vengeance in the poems in which she faces him as the vengeful goddess in her death aspect as the witch, his subsequent loss of Plath, and their final reunion that is achieved when he follows her voice in Birthday Letters.

Hughes's most audacious use of another story in Birthday Letters is in the poem 'Fairy Tale', in which he subverts the folk tale of 'Bluebeard' to describe how his actions unwittingly led to him releasing the grief that killed Plath. According to the folk tale, Bluebeard is a French aristocrat (with a blue beard) who has been married and widowed several times, though nobody in the village knows how his former wives died. Bluebeard visits his neighbour and asks to marry one of his neighbour's daughters. Each daughter,

317 The Epigraph to Hughes's Shakespeare and the Goddess of Complete Being is a quote from W.B. Yeats. 'At Stratford-on-Avon: Ideas of Good And Evil': "The Greeks, a certain scholar has told me, considered that myths are the activities of the Daimons, and the Daimons shape our characters and our lives. I have often had the fancy that there is some one myth for every man, which, if we but knew it, would make us understand all he did and thought." 
being frightened of him on account of his blue beard, refuses to marry him, until the youngest daughter is finally persuaded. She and Bluebeard are then married and she goes to live with him in his castle. At the castle, Bluebeard gives his bride a set of keys for each room of the castle but forbids her to open one specific room. Soon after providing his wife with the keys, he tells her that he must go away on business and leaves her alone in the castle. Before long, curiosity overcomes the young wife and she opens the door to the forbidden room. To her horror, she discovers it is drenched in blood and contains the bodies of her Bluebeard's former wives, hanging on the walls from hooks. Horrified she closes the door again and locks it. However, she has got blood on the key, which will not wash off and so when Bluebeard arrives shortly afterwards, he discovers her betrayal and is about to kill her when she is rescued by her brothers.

Hughes's use of the Bluebeard folktale in 'Fairy Tale' is audacious in the sense that he casts Plath as Bluebeard and himself as the wife. In the Plath myth, the role of Bluebeard, as the villain whose previous lovers died in mysterious circumstances, was particularly appropriate for Hughes. As Emma Tennant has said: "Like so many women who read Plath's famous poems in the late 60's, I feel I've lived through a climate of feminism in which, in colours as crude as a Punch and Judy show, Sylvia stands for the martyred female and Hughes for the murderous male." ${ }^{318}$ Tennant described her attraction to Hughes as the "Bluebeard syndrome" 319 and, in describing her curiosity about what happened between him and Sylvia says: "Like Bluebeard's wife, I have to know." 320 In 'Fairy Story', Hughes demonstrates the malleability of stories like 'Bluebeard, and the ease in which they can be used to obtain readers' sympathies or direct particular readings of events - or people.

\footnotetext{
318 Tennant, Emma. Burnt Diaries. Edinburgh: Cannongate Books. 1999. 48-9. Hereafter referred to as 'Burnt Diaries'.

319 'Burnt Diaries'. 49.

320 'Burnt Diaries'. 159.
} 
In 'Fairy Tale' Hughes recalls that Plath had a lucky number 'forty-nine', possibly a biographical reference, ${ }^{321}$ which denotes the number of chambers in her 'high palace', one of which, Hughes is forbidden to enter:

Forty-nine was your magic number.

Forty-nine this.

Forty-nine that. Forty-eight

Doors in your high palace could be opened.

Once you were gone off every night

I had forty-eight chambers to choose from.

But the forty-ninth - you kept the key.

We would open that, some day, together.

In 'Fairy Tale', Hughes suggests that each night Plath went off in sleep to visit her "Ogre lover", referring to the nightmares that she connected with her grief and guilt relating to her father's death. As in 'The Shot', Plath's "Ogre" 322 is equal to the "sum" of her former lovers; Hughes being the latest who she hoped would replace her dead father, if he does not betray her trust:

\section{Your Ogre}

Was the sum, crammed into one voodoo carcase,

Of all your earlier lovers -

You never told even your secret journal

How many, who, where, when.

Only one glowed like a volcano

Off in the night.

But I never looked, I never saw

His effigy there, burning in your tears

Like a thing of tar.

\footnotetext{
${ }^{321}$ In 'Fate Playing', Hughes describes Plath's joy: “And now your triumph, splashed over me , / like love forty-nine times magnified" (BL.32)

322 Plath comments about her father in 'The Journals': "He was an Ogre. But I miss him.” (p431).
} 
Like a sleeping child's night-light,

It consoled your cosmos.

The lover that "glowed like a volcano" is Otto. But Hughes is not given access to that room, and so Hughes remains unaware of what awaits him, until he opens the forbidden door behind which her dead father/Ogre lover awaits her:

I found that door. My heart hurting my ribs

I unlocked the forty-ninth door

With a blade of grass. You never knew

What a skeleton key I had found

In a single blade of grass. And I entered.

(BL.160)

Hughes describes his "heart hurting" as he opens the forty-ninth door with a "single blade of grass", which is a reference to his first illicit contact with Assia after her visit to Court Green. According to Koren and Negev, Hughes visited Assia at work at the Colman, Prentice and Varley advertising agency in Berkeley Square, only to find she was unavailable:

[Hughes] scribbled a note and left it with the receptionist. Intimate though it was, Assia showed it to her friends. Suzette Macedo recalls that it read, 'I have come to see you, despite all marriages.' Having always preferred rough waters to smooth sailing, Assia could not resist the thrill of responding. But she wanted to do it in striking, memorable fashion. From her office window she noticed a gardener was mowing the lawn in the square below, and therein she found her inspiration. She went down, picked a single blade of the freshly cut grass and sent it to Court Green... The blade of grass had been dipped in Dior perfume. ${ }^{323}$ Three days later an envelope arrived at Assia's office: in it, the blade of London grass lay beside one from Devon. ${ }^{324}$

${ }^{323}$ Hughes describes this incident in the poem 'Chlorophyl' (from Capriccio) (THC. 799)

324 'A Lover of Unreason'. 95-6. 
In 'Fairy Tale', when Hughes opens the forty-ninth chamber in Plath's palace with "a single blade of grass", his actions allow the Ogre, alias Otto, to escape from his chamber, kill Plath, and escape:

The forty-ninth chamber convulsed

With the Ogre's roar

As he burst through the wall and plunged

Into his abyss. I glimpsed him

As I tripped

Over your corpse and fell with him

Into his abyss.

(BL.160-1)

Hughes revises the end of the Bluebeard tale so that it is Plath's body he finds in the chamber, again, as in 'Sam' he describes her dead body as unexpectedly 'tripping' him, as he catches a glimpse of Otto and falls into the abyss that separates him from Plath.

In 'Being Christlike', Hughes uses the story of Christ to challenge the roles assigned in Plath's myth. In this poem, Hughes suggests that whether Plath wanted to be understood as a martyr or not, a reduced description of her life can be moulded into such a myth as to make it an irresistible interpretation:

You did not want to be Christlike. Though your father

Was your God and there was no other, you did not

Want to be Christlike. Though you walked

In the love of your father. Though you stared

At the stranger your mother.

What had she to do with you

But tempt you from your father?

When her great hooded eyes lowered

Their moon so close 
6 Re-writing the myth

Promising the earth you saw

Your fate and your cried

Get thee behind me. You did not

Want to be Christlike. You wanted

To be with your father

In wherever he was. And your body

Barred your passage. And your family

Who were your flesh and blood

Burdened it. And a god

That was not your father

Was a false god. But you did not

Want to be Christlike.

'Being Christlike', challenges Plath's role as a martyr by demonstrating the fanatical logic of such a reading of her suicide, which places her religious or political obligations over those of her own life and her family.

In my discussion of 'The God' in chapter five, we saw that Plath understood writing as a religious task and that, according to Hughes, "The story that has to be told / Is the writer's God" (BL.188). As true poets, Hughes and Plath followed the directions of their muse, who also appears in 'Fishing Bridge', where Hughes advises: "we / Only did what poetry told us to do" (BL.66). The problems Hughes and Plath encounter in Birthday Letters are often related to their misunderstandings of the story that is demanding to be told. In 'Setebos', for example, Plath and Hughes, at Plath's prompting, understand their relationship through the dramatic terms of Shakespeare's Tempest:

Who could play Miranda?

Only you. Ferdinand - only me.

And it was like that, yes, it was like that.

I never questioned. Your mother

Played Prospero, flying her magic in 
To stage the Masque, and bless the marriage,

Eavesdropping on the undervoices

Of the honeymooners in Paris

The younger Hughes and Plath never questioned their roles and believed they were safe in their story, anticipating a happy ending in their "spellbound future" safe from the dormant power of Sycorax (the White Goddess in her death aspect) and entertained by their kindly spirit Ariel, who appears to be a positive spirit of poetic inspiration. Caliban their 'secret', however, represents the uncivilised aspect of their psyche and, as they will learn, is the real source of their inspiration:

\section{Ariel}

Entertained us night and day.

The voices and sounds and sweet airs

Were our aura. Ariel was our aura.

Both of us alternated

Caliban our secret, who showed us

The sweetest, the freshest, the wildest

And loved us as we loved. Sycorax,

The rind of our garden's emptied quince,

Bobbed in the hazy surf at the horizon

Offshore, in the wings

Of the heavens, like a director

Studying the scenes to come.

Hughes describes Sycorax (the White Goddess) as directing the drama from the wings "studying the scenes to come". As the poem progresses it becomes apparent to the younger Hughes and Plath that they have misunderstood their roles in the drama. As we have seen, Ariel is in fact the vengeful Ariel voice that suddenly speaks through Plath, after being released from the Elm, and a new 'story' imposes itself upon their romance as they are transplanted into the Minoan labyrinth of Knossos: 
Then the script overtook us. Caliban

Reverted to type. I heard

The bellow in your voice

That made my nape-hair prickle when you sang

How you were freed from the Elm. I lay

In the labyrinth of a cowslip

Without a clue. I heard the Minotaur

Coming down its tunnel-groove

Of old faults deep and bitter. King Minos,

Alias Otto - his bellow

Winding into murderous music. Which play

Were we in?

(BL.132-3)

The confusion of stories and roles and scripts here emphasises Hughes's difficulty in making sense of the drama. Without a story to anchor themselves to, Hughes and Plath are all at sea, so to speak, and must now endure the tempest they have stumbled into, which is also the labyrinth. The Ariel voice can be heard bellowing down the labyrinth passages, and Hughes suggest this by echoing Plath's poem 'Event' in which she describes two lovers separated by "A groove of old faults, deep and bitter" (SPC.195) and elm in which the speaker talks of "the isolate, slow faults / That kill, that kill, that kill" (SPC.193). Hughes appears to be in the role of Theseus abandoning Ariadne, much earlier than in the original Greek myth. Unprepared for his adventure, Hughes does not even have time to kill the Minotaur before it finds her:

Too late to find you

And get back to my ship. The moon, off her moorings,

Tossed in a tempest. Your bellowing song

Was a scream in a bronze

Bull being roasted. The laughter

Of Sycorax was thunder and lightning 
And black downpour. She hurled

Prospero's head at me,

A bounding thunderbolt, a jumping cracker.

The moon's horns

Plunged and tossed. I heard your cries

Bugling through the hot bronze:

'Who has dismembered us?' I crawled

Under a gabardine, hugging tight

All I could of me, hearing the cry

Now of hounds.

In this final section of 'Setebos', Sycorax as the White Goddess links the myth of the Minotaur and The Tempest through an image of the horned moon plunging and tossing the stormy seas. Hughes now realises that he is not Theseus, or even Ferdinand, but a minor character, the jester Trinculo hiding from the storm under Caliban's gabardine, only to be mistaken by the other characters for a monster (The Tempest. Act II, Scene II). As he lies under the gabardine Hughes hears the hounds approaching for the next scene in which he will play the part of Actaeon, torn apart by the hounds after offending Diana. Desperately lost, Hughes hears Plath crying, "Who has dismembered us?" a line from her poem 'Event' (SPC.195), illustrating that this nightmare scenario is the breakdown of his and Plath's marriage.

The myth of the Labyrinth and the Minotaur is repeatedly employed throughout Birthday Letters to describe Plath's moments of emotional turmoil. In 'Your Paris', for example, Hughes says that, to Plath, Paris "Was a labyrinth / Where you still hurtled, scattering tears, / Was a dream where you could not / Wake or find the exit or / the Minotaur to put a blessed end / to the torment" (BL.38). And in 'The Minotaur', Hughes describes himself encouraging Plath to vent her anger in her writing, and providing her with the skein to find her way to the centre of the maze, and the Minotaur:

Deep in the cave of your ear 
The goblin snapped his fingers.

So what had I given him?

The bloody end of the skein

That unravelled your marriage,

Left your children echoing

Like tunnels in a labyrinth,

Left your mother a dead-end,

Brought you to the horned, bellowing

Grave of your risen father -

And your own corpse in it.

(BL.120)

In 'Fishing Bridge', Hughes's and Plath's quest for the "perfected vision" (BL.88) in their poems leads them away from the world and into the labyrinth of themselves. Following their separate threads of inspiration they find themselves in "an unlit maze of crying and loss" (BL.88). Following their inspiration, for Hughes, meant resisting the confines of domesticity; for Plath it meant rediscovering her unresolved grief for her father. When they arrive at the maze's centre the perfected vision is brutal:

Till it stopped. Was that the maze's centre?

Where everything stopped? What lay there?

The voice held me there, by the scruff of the neck, And bowed my head

Over the thing we had found. Your dead face.

Your dead lips, dry, pale. And your eyes

(As brown-bright, when I lifted the lids, As when you gazed across that incandescence)

Unmoving and dead.

(BL. 88) 
Hughes's use of pre-existing stories in Birthday Letters has resulted in some criticism of the sequence from one of Hughes's most ardent supporters. In The Laughter of Foxes, Sagar suggests that Birthday Letters is "not part of the main body of Hughes's achievement" because the work was simply his "treatment of already existing material... the already well-documented factual record of his relationship with Sylvia Plath... [in which] the plot was pre-determined. ${ }^{325}$ Sagar suggests that, because of this, Birthday Letters did not allow Hughes "the total imaginative freedom his greatest work needed". 326

Sagar's criticism of Birthday Letters on these grounds seems at odds with his comments, which I quoted earlier in this chapter, about the way Hughes "sought appropriate myths, or adaptations or amalgamations of myths, to help him in his effort to place his own little life in the context of permanent or recurrent experience in a world larger than the merely human."327 Nor does Sagar acknowledge that, in Birthday Letters, Hughes is attempting to re-write and contend with a myth and its attendant discourses, in order to recover his own subjective experiences and conclusions. Hughes's acknowledgement of the subjectivity of his and Plath's myth-making in Birthday Letters suggests to Sagar that the stories in Birthday Letters are inadequate to their task and demonstrate "Hughes's continuing failure to make sense of those years". As we saw in chapter two, Hughes said that the imagination was a matrix of stories through which we attempt to make sense of the events in our lives and give form to our inner subjective experiences. The over-determinacy of events and actions in Birthday Letters, in terms of their multiple correlating narratives, demonstrates that if there is any truth to be made of Hughes's and Plath's experiences, it is provisional and subjective, and has been constructed from the stories they have inherited. In other words, by showing how easily the imagination that is saturated in myth and folklore can manipulate a story, Hughes highlights the provisional, speculative, and subjective nature of the discourses surrounding the Plath myth that he has been trapped in.

\footnotetext{
325 'The Laughter of Foxes'. $x$.

326 'The Laughter of Foxes'. $x$.

327 'The Laughter of Foxes'. 83.
} 
Sagar suggests that rather than translating his experiences through The Tempest, the myth of the Minotaur, and so on, Hughes should have used the tale of Orpheus and Eurydice, which he alludes to in 'A Picture of Otto'. However, Sagar advises that Hughes had rejected this story earlier as being "too obvious an attempt to exploit my situation". ${ }^{328}$ Sagar points out that Hughes's very last work was his version of Euripides's Alcestis, which is another version of the tale of a hero's quest to recover a dead lover from the underworld. In this myth King Admetos's wife, Alcestis, dies in his place, until she is successfully rescued from the underworld by Admetos's friend Heracles and restored to Admetos. Sagar points out that Alcestis was not commissioned like other translations, "but [was] a work on which he chose to spend his increasingly precious time", which suggests to Sagar that Hughes embarked on this translation "feeling perhaps that in the long agony recorded in Birthday Letters he had finally paid for the right to lay claim to the story". ${ }^{329}$ Sagar points out that the play's last words (and thus the last words of Hughes's last work) were: "Let this give man hope" suggesting that, although in Birthday Letters Hughes did not recover Plath, he was still able to recover "the memories of joys, births and indestructible love, [which were] a healing gift." 330

Sagar is right to point out the significance of the myth of Orpheus and Eurydice in the Birthday Letters sequence and in the next chapter we will see how this myth was finally too irresistible a story for Hughes to avoid 'exploiting' as a ritual of imaginative catharsis.

\footnotetext{
${ }^{328}$ Letter from Ted Hughes to Keith Sagar quoted in: 'The Laughter of Foxes'. 84.

329 'The Laughter of Foxes'. 85.

330 'The Laughter of Foxes'. 86.
} 


\section{The Shamanic Journey}

Hughes's notion of the poet as a 'healer' was derived from his reading of The White Goddess in which Graves claimed the original role of poetry was to create hymns to the original Goddess to help re-establish the connection between primitive man's inner world and his outer material world. By reconciling himself with nature (and his own nature) which is the Goddess, the poet and his tribe were healed in the sense that a connection was re-established between the individual and something more permanent and meaningful than the conscious ego.

Believing that this was the main function of true poetry, Hughes compared the role of the poet to that of the shaman in ancient societies. Both the poet and the shaman attempted to heal their 'tribe' through their magical song. In his 1964 essay 'Regenerations', Hughes explained that in various cultures shamans are chosen in a number of ways but are usually elected after a visit from the "spirits", or the Goddess, who appears in the form of an animal helper:

The most common form of election comes from the spirits themselves: they approach the man in a dream. At the simplest, these dreams are no more than the vision of a flying eagle... but at the other extreme, the dreams are long and complicated, and dramatize in full the whole psychological transformation that any shaman, no matter how he has been initially chosen, must undergo. ${ }^{331}$

As a shaman-poet, Hughes's totem-animal was the fox, which became, for him, a symbol of the healing energy that is the source of all true poetry and as a symbol of his poetic self. Over the years, Hughes described several encounters with foxes at crucial times in his life, such as the following incident described by Sagar in The Laughter of Foxes. Sagar points out that while Hughes was at school in Mexborough, South Yorkshire, he often left for school early so that he could investigate the wildlife beside

\footnotetext{
331 'Winter Pollen'. 57.
} 
the river Don. One morning, while exploring the riverbank, Hughes had a significant experience, which Sagar describes:

On one occasion, as he climbed one side of the hollow, quite unknown to him a fox was climbing the other. They arrived at the ridge simultaneously, and looked into each other's eyes from a distance of a few inches. For a split second, which seemed timeless, Hughes felt that the fox had leapt into his head, supplanting his own provisional human nature with its own definitive foxhood. This was the kind of experience he most wanted from the natural world, encounters with another, deeper reality, with something so totally other as to be sacred, yet also able to speak as nothing else could to his own depths, depths beyond all conditioning and education. $^{332}$

According to Sagar, the fox revealed to Hughes an experience beyond his ego-centric world-view. In this encounter with the fox, Hughes experienced and recognised an untrained unconscious part of the psyche he had been neglecting. He repeatedly attempted to recapture this uncivilized inner energy in his poems. In his poem 'The Thought-Fox', for example, the 'fox is neither 'thought' nor 'fox', but something that is both: a wild uncontrollable psychological event. The fox of this poem is not just a symbol of the poet's inspiration but a manifestation of the poetic energy itself. It is the presence that enters the speaker's consciousness from the dark periphery and finds its way onto the page as the poet simultaneously becomes fully aware of its presence. Middlebrook has pointed out that Hughes remembered writing 'The Thought-Fox' "because the technique of composition seemed to arise from a part of his brain he hadn't used before, and that he had used again in only a few poems, and that those poems were 'special' to him." "333 The importance of 'The Thought-Fox' to Hughes is, perhaps, demonstrated by the fact that he used it as the opening poem in every edition of his Selected Poems from 1962 to 1994.

332 'The Laughter of Foxes'. 42.
333 'Her Husband'. 148. 
Hughes described another encounter with a fox in his short story "The Deadfall', which he wrote for Michael Morpurgo's anthology of ghost stories for children Ghostly Haunts (1994) but had said that story was based on "an early experience... with a few adjustments to what I remember". ${ }^{334}$ In 'The Deadfall', the first-person narrator is a young boy who is out camping with his older brother. The boy is awoken in the night by a ghostly woman, who leads him to rescue a fox-cub whose leg and tail are trapped under a deadfall trap. The boy manages to lift the stone slightly so the fox can escape and, returning on the following day with his brother, they discover a dead adult fox beneath the deadfall trap stone and conclude that the lady that had led the boy to rescue the foxcub had been the ghost of the dead adult fox. I will be looking at the significance of the symbolism in this story in more detail in the epilogue.

In his essay 'The Burnt Fox', Hughes described another experience he had while studying English at Cambridge. In this essay, he recalls how, after struggling to write a literary criticism essay into the early hours of the morning, he eventually gave up and fell asleep in his bed, which was beside his writing desk:

I began to dream... Suddenly my attention was drawn to the door. I thought I had heard something there. As I waited, listening, I saw the door was opening slowly. Then a head came round the edge of the door. It was about the height of a man's head but clearly the head of a fox - though the light over there was dim. The door opened wide and down the short stair and across the room towards me came a figure that was at the same time a skinny man and a fox walking erect on its hind legs. It was a fox, but the size of a wolf. As it approached and came into the light I saw that its body and limbs had just now stepped out of a furnace. Every inch was roasted, smouldering, black-charred, split and bleeding. Its eyes, which were level with mine, dazzled with the intensity of the pain. It came up until it stood beside me. Then it spread its hand - a human hand as I now saw, but burned and bleeding like the rest of him - flat palm down on the blank space of my page. At

\footnotetext{
${ }^{334}$ Hughes, Ted. Difficulties of a Bridegroom. London: Faber and Faber. 1995. ix. Hereafter referred to as 'Difficulties of a Bridegroom'.
} 
the same time it said: 'Stop this - you are destroying us.' Then as it lifted its hand away I saw the blood-print, like a palmist's specimen, with all the lines and creases, in wet, glistening blood on the page. I immediately woke up. The impression of reality was so total, I got out of bed to look at the papers on my table, quite certain that I would see the blood-print there on the page. ${ }^{335}$

Hughes believed this dream was significant enough to drop English at the end of the year to take Archaeology and Anthropology. As he explained in a 1979 letter to Sagar, he understood the fox's appearance as a warning about his neglect of his true subjective self and his inner needs by focusing too much on the objective world - the world he associated with prose and reason:

I connected the fox's command to my own ideas about Eng. Lit., \& the effect of the Cambridge blend of pseudo-critical terminology and the social rancour on creative spirit, and from that moment abandoned my efforts to adapt myself. I might say, that I had as much talent for Leavis-style dismantling of texts as anybody else, I even had a special bent for it - nearly a sadistic streak there, - but it seemed to me not only a foolish game, but deeply destructive of myself. ${ }^{336}$

Hughes's notion of the poet as a shaman is considered by Hirschberg in his book, Myth in the Poetry of Ted Hughes. Hirschberg suggests that the relationship between Hughes and the animals, particularly in his early poems, is "based on shamanistic rites" and corresponds with the relationship between the shaman in ancient societies and his "helper animals". By identifying wholly with the animal's point of view, Hughes achieves an imaginative transformation, similar to that of the shaman donning the pelt of an animal. According to Hirschberg, Hughes's early poems "serve a personal, psychological function so that through violence, primitive contact with a suppressed hatred and repressed aggression and even a kind of psychic self-mutilation, the sterile

\footnotetext{
${ }^{335}$ Hughes, Ted. 'The Burnt Fox'. [1993] Winter Pollen: Occasional Prose. London: Faber \& Faber. 1994, 9. Hereafter referred to as 'Winter Pollen'.

336 'The Laughter of Foxes'. 46.
} 
personality created by society is destroyed and the instinctual suppressed self can emerge liberated." 337

In 'Hawk Roosting', for example, we overhear the hawk thinking and learn that she (Hughes originally imagined the hawk as a female and as the voice of Nature) is perfectly in tune with, and in control of, her environment. Every feather of the hawk serves her, as do the high trees, the air that lifts her, and the sun that warms her. The hawk lives because others die for her; her role in her environment is clear - she is the dispenser of death. The hawk does not suffer from guilt or doubt, or ambition, she is not subject to abstract ratiocination or self-deception. She suffers "no falsifying dream" (THC. 19) and her dreams do not serve as dramatic wish fulfilments but are simply rehearsals in the perfection of her everyday life. ${ }^{338}$

Throughout Hughes's poetry animals appear in a didactic role, issuing warnings about the extent to which humans have become estranged from their true inner selves and providing examples of how to live fully within the world. This is true of the animals that appear in Birthday Letters. The bats in 'Karlsbad Caverns', for example, are shown to be perfectly attuned to their inner and outer worlds, they are contented and do not question their role in the cosmos:

Presumably the whole lot were happy -

So happy they didn't know they were happy,

They were so busy with it, so full of it,

Clinging upside down in their stone heavens.

Hughes and Plath have visited the caverns to witness the spectacle of the bats leaving the caverns together, triggered collectively by some cosmic "clockwork" to hunt for insects.

\footnotetext{
337 'Myth in the Poetry of Ted Hughes'. 12.

338 'Myth in the Poetry of Ted Hughes'. 14.
} 
As they watch, the millions of bats leave the cave as expected, "to the minute", and spiral up into the sky:

And that was how it should be.

As every night for how many million years?

A clockwork, perfected like their radar.

The younger Hughes and Plath are impressed by the bats collective sense of purpose, their intuitive interaction with their environment. The existence of the bats is in stark contrast to themselves and highlights their doubt, hesitancy, and uncertainty. Unlike the bats, Hughes and Plath are as deaf to their own needs as they are to each other's, and they must work hard to learn what makes them happy. Hughes and Plath are 'sleepwalkers' guided by their artificially constructed personalities and are helplessly lost in this natural environment, not even knowing where they will spend that evening:

We weren't sure whether to stay that night or go.

We were where we had never been in our lives.

Visitors - visiting even ourselves.

The bats were part of the sun's machinery,

Connected to the machinery of the flowers

By the machinery of insects. The bats' meaning

Oiled the unfailing logic of the earth.

Cosmic requirement - on the wings of a goblin

A rebuke to our half-participation.

(BL. 100)

While the bats offer the younger Hughes and Plath a "rebuke" to their "halfparticipation" in the cosmos, the older Hughes, looking back and narrating the poem sees the bats as offering another lesson. As they watch the millions of bats leave the caverns together they see the entire cloud unexpectedly turn about in the sky. The bats have 
somehow detected a storm approaching and dive back into the cave to remove themselves from danger. To the older Hughes interpreting the bats' behaviour retrospectively the bats offer a further "rebuke":

Those bats had their eyes open. Unlike us,

They knew how, and when, to detach themselves

From the love that moves the sun and the other stars.

(BL.101)

The bats offer themselves as a symbol of a kind of existence in which the needs of the inner and outer worlds are completely reconciled. In contrast to the bats, Hughes and Plath head blindly into danger as they fail to recognise and reconcile their own inner needs and each other's. All of the characters in Birthday Letters are described as sleepwalking and as existing in a "bat-light" (BL.74). They do not have their "perfected" radar of the bats and so cannot discern their real needs and adjust their course accordingly to avoid the coming storm.

Throughout Birthday Letters, Hughes portrays his younger self's estrangement from his inner life, and his blindness to Plath's true self, by aligning his perceptions with those of an animal estranged from its true self, the domesticated dog. In 'The Machine', for example, Hughes describes himself as having "no more purpose in me / Than in my own dog / That I did not have” (BL.25). In 'Your Paris', Hughes describes himself as being "like a guide dog, loyal to correct [Plath's] stumblings" (BL.38) and recalls how, being deaf to Plath's inner terrors, “the mere dog in me, [was] happy to protect you from your agitation and your stone hours" (BL. 38). In 'Moonwalk', Hughes describes his incomprehension of Plath's true self (or the Ariel voice) in the same terms:

I walked beside you -

As if seeing you for the first time -

The moon shadow of a strange dog,

The silent shadow of a dog

That had befriended you.

(BL. 42) 
And, in 'The Afterbirth', Hughes portrays the incompleteness of his experiences and understanding by describing himself as an insubstantial two-dimensional figure that is again connected to the dog symbol:

\section{I felt}

Like somebody's shadow on a cave wall.

A figure with a dog's head

On a tomb wall in Egypt.

Hughes employs the dog as a symbol of ignorance, misunderstanding, and estrangement from the truth throughout Birthday Letters and not only in his descriptions of his younger self. For example, in 'God Help the Wolf after Whom the Dogs Do Not Bark' and 'The Dogs Are Eating Your Mother', he uses the dog symbol to portray the ignorance of Plath's critics and biographers.

In opposition to the dog, as a symbol of the highest enlightenment and inspiration, Hughes employs his totem animal, the fox, which appears at a moment of insight and clarity in the poem 'Epiphany'. As the title suggests, 'Epiphany' records the moment that Hughes becomes aware of his estrangement from his authentic self when he encounters a fox-cub in London. Assuming that the events described in 'Epiphany' really happened and are not purely symbolic, the poem recalls an incident that occurred when Hughes was, "a new father" (BL.113), walking through London one evening to catch a train home. As he crosses Chalk Farm Bridge Hughes recalls he suddenly "noticed (I couldn't believe it) / What I'd been ignoring" (BL.113). Peering from between the jacket lapels of a man walking towards him from the opposite direction, Hughes notices a fox-cub. The man offers to sell Hughes the fox-cub for a pound and as he considers the offer he notices the fox-cub seems to be in distress and in need of his help:

The little fox peered past me at other folks, At this one and that one, then at me, 
Good luck was all it needed.

Already past the kittenish

But the eyes still small,

Round, orphaned-looking, woebegone

As if with weeping. Bereft

Of the blue milk, the toys of feather and fur,

The den's happy dark. And the huge whisper

Of the constellations

Out of which Mother had always returned.

(BL. 114)

Despite sensing the fox-cub's distress, Hughes rejects the offer. He does so, he explains, because he believed it was impossible for him to take the fox-cub back to his home with Plath; he is unable to reconcile his domestic situation with the fox-cub's "mannerless energy" and its appetite "for everything beyond us":

\section{What I was thinking}

Was - what would you think? How would we fit it

Into our crate of space? With the baby?

What would you make of its old smell

And its mannerless energy?

And as it grew up and began to enjoy itself

What would we do with an unpredictable,

Powerful bounding fox?

The long-mouthed, flashing temperament?

That necessary nightly twenty miles

And that vast hunger for everything beyond us?

Hughes's refusal of the distressed fox-cub, his failure to rescue it, represents his refusal of the needs of his authentic self and a denial of his vocation as a true poet in the Gravesian sense. As he rejects the fox-cub, Hughes describes his own perceptions as those of his totem animal's nemesis, the domesticated hound: 
My thoughts felt like big, ignorant hounds

Circling and sniffing around him.

Then I walked on

As if out of my own life.

I let that fox-cub go. I tossed it back

Into the future

Of a fox-cub in London and I hurried

Straight on and dived as if escaping

Into the Underground.

(BL. 114)

Through the drama of this encounter in 'Epiphany', Hughes suggests that he believed the needs of his instinctive inner self and those of his domestic responsibilities had become incompatible. As Sagar puts it:

Hughes asks what in him can answer to this fox-cub. He identifies the fox with his own inner meaning, his authenticity, the ultimate truth of his being, the god or luminous spirit in him, the nagual, the duende. It is that part of each of us that the pressures of living in our society, the compromises demanded by relationships and domestic responsibilities, force us to walk away from, to ignore or repudiate, to condemn to suffering or death with neglect. ${ }^{339}$

'Epiphany' thus records the moment that Hughes suddenly realises that the survival of his inner wildness is being threatened by his domestic situation; with this realisation comes the knowledge that his marriage had failed:

\section{If I had paid,}

If I had paid that pound and turned back

To you, with that armful of fox -

339 'The Laughter of Foxes'. 61. 
If I had grasped that whatever comes with a fox

Is what tests a marriage and proves it a marriage -

I would not have failed the test. Would you have failed it?

But I failed. Our marriage had failed.

Like the bats in 'Karslbad Caverns', the fox-cub that appears in 'Epiphany' issues a warning to Hughes about nurturing this instinctive wildness that is both his authentic self and his creative source. Through the drama of "Epiphany' Hughes suggests that because his inner needs were incompatible with the responsibilities of his marriage, he attempted to escape the demands of his inner self by ignoring them. However, as the mythopoeic terms of Birthday Letters demonstrate, it is impossible to hide from one's true self and from one's inner needs forever, and when one attempts to do so, the results can be self-destructive.

If Hughes needed any justification for his feelings about the incompatibility of his marriage and vocation as a poet, he only needed to look to The White Goddess in which Graves warns poets to resist at all costs "the temptation to commit suicide in simple domesticity". ${ }^{400}$ According to Graves, "the poet cannot continue to be a poet if he feels that he has made a permanent conquest of the Muse, that she is always his for the asking" "341 because "The White Goddess is anti-domestic; she is the perpetual 'other woman"”, ${ }^{342}$ For Graves, this explained why so many young poets stopped writing poetry "after their early twenties":

The reason is that something dies in the poet. Perhaps he has compromised his poetic integrity by valuing some range of experience or other - literary, religious, philosophical, dramatic, political or social - above the poetic. But perhaps he also has lost his sense of the White Goddess: the woman who he took to be a Muse, or who was a Muse, turns into a domestic woman and would have him turn similarly into a domesticated man. Loyalty prevents him from parting company with her,

\footnotetext{
340 'The White Goddess'. 449.

341 'The White Goddess'. 444.

342 'The White Goddess'. 449.
} 
especially if she is the mother of his children and is proud to be reckoned a good housewife; and as the Muse fades out, so does the poet. ${ }^{343}$

Middlebrook has suggested that "in Hughes's moral code, preserving the life of the instincts was an ethical action". Consequently, she suggests that embarking on an affair with Assia Wevill was Hughes's way of "rescuing his instinctual life from suffocation." ${ }^{344}$ Whether Hughes is attempting to justify his infidelity in these terms is unclear. However, it is certain that in 'Epiphany' he is describing what he sees as a betrayal of his true self that explains the failure in his marriage - it is the moment that Hughes realises there is a problem he is unable to solve, or at least, that his younger self was unable to solve.

In a 1994 essay, Hughes distinguished between the 'poet' and the 'dreamer' by arguing that the art of the 'dreamer' is "the stuff of symptoms" whereas the art of the poet contains "the healing response". He believed the poet's role was to recover the healing energies of the psyche, arguing that "true poetry... is a healing substance" that is created "in a natural and spontaneous way, by the psychological component of the auto-immune system, the body's self-repair system.”345 This explained for Hughes why we value great works of art and why they endure:

We recognize [great works of art], eventually, because we find they do in fact heal us - or they make us feel as though we were being healed, we search them out like the sick animal seeking out the specific healing herb. Finally, mankind values these works because it needs them. In the end, it doesn't treasure anything else. Apart from curiosities, these are the only relics of any people or age that we hang on to - and we do that because they still carry 'healing' power. Though maybe we only call it 'beauty'. ${ }^{346}$

\footnotetext{
343 'The White Goddess'. 449.

344 'Her Husband'. 182.

345 'Winter Pollen'. 249.

346 'Winter Pollen'. 249-50.
} 
In the sense that Birthday Letters tells the story of his marriage to Plath, of her suicide and of their dismemberment by the myth that consumed their identities, the sequence can be said to be a record of the "symptoms" of the wound that Hughes suffered through his adult life. However, Birthday Letters also offers the "healing response".

Hughes's notion of the poet as shaman helped him diagnose 'the wound' that led to the breakdown of his marriage in 'Epiphany' but it also directs his healing response in Birthday Letters in which he attempts to recover his private impressions and conclusions about Plath from the antagonistic terms of their myth. As we have seen, Hughes believed that stories help us make sense of our behaviours, actions, relationships, and our past. Stories contain our explanation of who we are, our motivations and actions, where we fit in the world and why our world is this particular way. For Hughes, the most important stories were myths because they contained the symbols and drama that allow us to reconcile our inner needs with our outer worlds. As we saw in chapter two, in his essay 'Myth and Education', Hughes remarked:

A story which engages, say, earth and the underworld... contains not merely the space and in some form or other the contents of these two places; it reconciles their contradictions in a workable fashion and holds open the way between them. $^{347}$

To tell his own story in Birthday Letters, Hughes must recover his own unadulterated impressions of Plath from the discourses that have dismembered her and reconfigured her in their variant versions of her myth. Hughes does this by adopting a variant of the Goddess myth, that is, the myth of the shaman's journey, in which the hero mourning his (or her) lover and attempting to recover her from the Underworld. The myth of the mourning hero entering the Underworld has been understood in psychoanalytical terms as an archetypal dramatic metaphor for the psychological healing process. A Jungian would argue that this story describes the conscious ego confronting and being destroyed by the dark unconscious powers of the psyche. The hero must enter

347 'Winter Pollen'. 138-9. 
the underworld to reunite with the energies of his authentic self, and the lover who he recovers, in being a variant of the Goddess myth, is also that wild uncivilised aspect of the self. In Birthday Letters this mythic drama serves on two levels, as a description of Hughes's imaginative journey to recover his dead wife, and as a description of the cathartic psychological process itself. In this way, Birthday Letters can be seen as mirroring what Hughes saw occurring in Plath's Ariel poems as the kind of poetry in which "the substance of her poetry and the very substance of her survival are the same." 348

Several critics have noted the parallels between Birthday Letters and the myths that feature a mourning hero. In his essay 'Sorrow Doubled', for example, Jon Stallworthy suggests the myth of Echo and Narcissus frames Hughes's address of Plath in Birthday Letters and accounts for the roles played by the story's main characters. ${ }^{349}$ Plath plays the role of Narcissus, finding herself reflected in everything she perceives and Hughes is Echo, mourning his dead lover and forced to echo her utterances in order to both mourn and celebrate her. Stallworthy points out that in Hughes's version of this myth in Tales from Ovid, Juno, the Roman goddess of marriage warns Echo:

\section{'Your tongue}

Has led me in such circles, Henceforth

It will have to trail

Helplessly after others, uttering

Only the last words, helplessly, Of what you last heard. ${ }^{, 350}$

As Stallworthy points out, in Birthday Letters, Hughes, like Echo, mourns and celebrates Plath in her own words, and is forced to use her words to describe his own subjective

\footnotetext{
348 'Winter Pollen'. 184.

349 Stallworthy, Jon. 'With Sorrow Doubled'. In: Gammage, Nick. The Epic Poise: A Celebration of Ted Hughes. London: Faber and Faber, 1999. 138.

${ }^{350}$ Hughes, Ted. Tales from Ovid. London: Faber \& Faber, 1997. 76.
} 
experiences. The myth of Echo and Narcissus is a useful analogy for the way that Hughes revisits the language, symbols and drama in Plath's poems in Birthday Letters but it is not the framing myth of the sequence. Stallworthy's reading simply offers an example of the plasticity of myths' archetypal materials, and of how our most ancient stories have, over millennia, continued to provide the symbolic means to capture and make sense of our experiences. The myth of Echo and Narcissus is actually a variant, or a fragment of a variant, of a particular type of myth that is found in mythological cycles in different cultures throughout the world and relates to the journey of the sacred king into the underworld to be united with the Goddess in his resurrection. The most famous variant of this story in the West, and the version Hughes had in mind during the writing of Birthday Letters is the ancient Thracian tale of Orpheus and Eurydice.

Hughes would have known that the myth of Orpheus and Eurydice is associated with the Orphic mystery cult and with shamanism, a religious practice that originated in Siberia and travelled across Asia into Thrace - the home of Orpheus. In his book Classical Myth, Barry Powell links Orpheus directly with the shaman and argues that the story records a shamanic journey in which the shaman converses with the dead and recovers the truth:

The myth of Orpheus [is] more than a simple folktale, the story of a man who went to the other world and returned, because we can view Orpheus as a shaman in his own right, returning from the underworld to teach the truth about human nature and destiny. ${ }^{351}$

For Hughes, the poet's and the shaman's roles are practically identical. The shaman's main roles are to gather knowledge, to heal the sick, and to recover lost souls from the land of the dead. The shaman journeys to the underworld while in an ecstatic trance brought about by discipline, music, and magic; he does so to recover the healing energies necessary for his community or tribe. In this way, the shaman can prevent

\footnotetext{
${ }^{351}$ Powell, Barry B. 'Myths of Death: Encounters with the Underworld'. Classical Myth. Fourth Edition. New Jersey: Pearson Prentice Hall, 2004. 306. Hereafter referred to as 'Classical Myth'.
} 
members of his tribe suffering, as Powell points out: "It is only with great effort, austerity, and with the help of knowledge gained from the Orphic revelation that the soul can be purified and the cycle of rebirth broken." ${ }^{352}$ Given the repeated death and rebirth Hughes describes in Plath' poems, his mission in Birthday Letters is to free Plath and himself from the antagonistic terms of her myth and release them both from the cycle of rebirth into suffering.

In her essay 'Mourning Eurydice: Ted Hughes as Orpheus in Birthday Letters', Bundtzen illustrated the strong parallels between the story of Birthday Letters and the myth of Orpheus and Eurydice. According to Bundtzen's reading, in Birthday Letters Hughes takes the role of Orpheus, and Plath is cast as Eurydice, his dead wife for whom he mourns. Orpheus, the son of the Muse Calliope (another variant of the White Goddess), was an augur, astrologer, a seer, but was most famous for being the first poet, whose songs were said to be able to charm birds, wild animals, trees and even rocks into dance. Hughes is well known for his nature poetry and in Birthday Letters, as Orpheus, he is able to charm the birds and animals with his songs. In 'The Owl', for example, Hughes depicts himself, as he appears in some of Plath's early writings (such as 'Ode for Ted' (SPC.29)), as controlling nature with his magic, and making it perform for her:

I made my world perform its utmost for you.

You took it all in with an incredulous joy

Like a mother handed her new baby

By the midwife. Your frenzy made me giddy.

It woke up my dumb ecstatic boyhood

Of fifteen years before. My masterpiece

Came that night on the Granchester road.

I sucked the throaty thin woe of a rabbit

Out of my wetted knuckle, by a copse

Where a tawny owl was enquiring.

Suddenly it swooped up, splaying its pinions

352 'Classical Myth'. 306. 
Hughes, as Orpheus, easily conjures the tawny owl out of the darkness because nature is at the command of his song, or, at least, it appears to be. The owl that appears at the end of the poem, mistaking Hughes for a post, would have been interpreted by Orpheus as an appearance of the Goddess. However, the younger Hughes does not appear to notice the bird's portentous value; as an auger and seer in Birthday Letters, the young Hughes is not particularly adept because he is still tied up with his own conscious personality. In 'Caryatids (1)', he confesses that "In those days I coerced / Oracular assurance / In my favour out of every sign" (BL.4) and that he and his friends are "careless / Of grave life", believing that they have "Time in plenty / to test every role" (BL.5). In 'St Boltoph's', he describes himself as a "a wait-and-see astrologer" (BL.14) and in 'Karlsbad Caverns' it is only the older Hughes, narrating, who is able to describe the meaning of the bats' flight retrospectively. The distinction between Hughes the narrator and his younger self can be related to Hughes's distinction between "the dreamer" and "the poet". As the sleepwalking character of Birthday Letters, Hughes can be seen as the "sleepwalking" dreamer who misses all the omens and portents that warn him of the impending tragedy. However, as the older narrator, looking back and retrospectively making sense of the drama, Hughes is the poet and is Orpheus, the shaman, undertaking a journey in order to make sense of his story in mythic terms and recover a healing vision.

According to Virgil's version of the myth, Eurydice was killed while fleeing the amorous advances of Aristaeus ${ }^{353}$ the beekeeper when she steps into a nest of snakes and is fatally bitten on the heel (in Birthday Letters, Hughes casts Otto Plath in the role of Aristaeus, Plath's amorous pursuer). Following Eurydice's death, Orpheus mourns her in songs that move the nymphs and the gods to weep. On their advice, Orpheus travels to the Underworld to try and recover her. Arriving in the Land of the Dead, Orpheus's songs soften the hearts of Hades and Persephone and Hades agrees to let Orpheus leave

\footnotetext{
${ }^{353}$ Aristaeus was the son of Apollo, the god of light and poetry. According to Robert Graves, Apollo replaced the more ancient White Goddess's function as Muse when patriarchal tribes overcame matriarchal tribes and replaced the all powerful Mother Goddess with their patriarchal gods. Apollo's sister was Semele, the goddess of the moon, a less powerful version of the original Mother Goddess.
} 
with Eurydice on one condition: that he walks in front of Eurydice and does not look back until they have both reached the upper world. Orpheus agrees, but as he reaches the upper world, he glances back anxiously to confirm Eurydice is following; at that moment Eurydice vanishes and Orpheus loses her again, but this time forever. ${ }^{354}$

The historical parallels between Hughes and Plath's story and the myth of Orpheus and Eurydice are immediately apparent and, in Birthday Letters, Hughes makes use of these correlations to frame his experiences in a way that suits his own subjective understanding. In the mythopoeic frame of Birthday Letters Plath's preoccupation with her father parallels Eurydice's fateful encounter with Aristaeus the beekeeper, the rival of Orpheus and the one responsible for her death. Throughout Birthday Letters, as we have seen, Plath is pursued not by Hughes (as in her poem 'Pursuit'), but by her father (as in 'The Shot', 'The Bee God', 'The Hands', and 'Being Christlike').

Although the myth of Orpheus and Eurydice appeared in Ovid's Metamorphoses, Hughes did not include it in his translation Tales from Ovid. As we saw in the last chapter, in a letter to Keith Sagar, Hughes said that he had rejected the tale of Orpheus and Eurydice as "too obvious an attempt to exploit my situation" 355 Nevertheless, in 1970 he did write a play of the tale of Orpheus and Eurydice, which appeared in his book for children The Tiger's Bones, which, until after his death, was only published in the United States, after which it appeared in England in the posthumous Collected Plays for Children (2001). In a letter to his brother Gerald, Hughes said that the fables he wrote for children were full of "psychic symbols" that would help children explain their inner lives to themselves ${ }^{356}$ and it appears that in his adaptation of this myth for children, Hughes discovered the mythopoeic means of recovering Plath that is employed in Birthday Letters. In the play 'Orpheus' the hero goes into the underworld to ask Pluto for the return of his wife. Pluto advises Orpheus, "Your wife's body is crumbling to dust" and therefore she cannot return to earth. However, he does allow Orpheus to return to the earth with Eurydice's soul. As Orpheus is leaving the underworld, he turns to confirm

\footnotetext{
354 'Mourning Eurydice': 455-469.

355 'The Laughter of Foxes'. 84.

356 'Her Husband'. 98.
} 
that Eurydice is following, as in the ancient myth, and finds "the air is empty". ${ }^{357}$ It is here, then, that Hughes subtly alters the myth to suit his own purposes. In his play, Orpheus does not lose Eurydice, as in the ancient myth, because although he cannot see her, he has recovered her voice:

$\begin{array}{ll}\text { ORPHEUS: } & \text { Eurydice? } \\ \text { EURYDICE: } & \text { I am here. } \\ \text { ORPHEUS: } & \text { Eurydice, where are you? } \\ \text { EURYDICE: } & \text { Here at your side, Orpheus. } \\ \text { NARRATOR: } & \text { He cannot see her. He cannot touch her. He can only hear } \\ & \text { her. He listens. }\end{array}$

In the play, Orpheus does not recover his dead wife but he does recover her voice, and, after listening to her, he begins to sing again himself. The new song of Orpheus is no longer a song for dancing but a song about eternity and the endless cycle of death and rebirth; it is a poem about eternity, and is clearly a love-hymn to the Goddess:

NARRATOR: $\quad$ The music was not the music of dancing

But of growing and withering,

Of the root in the earth and the leaf in the light,

The music of birth and death.

And the stones did not dance. But the stones listened.

The music was not of happiness

But of everlasting, and the wearing away of the hills... ${ }^{359}$

Hughes's play 'Orpheus' explains how he 'exploits' the myth of Orpheus and Eurydice as a structuring principle in Birthday Letters in order to recover Plath and recover himself from her myth. In Birthday Letters Hughes attempts a shamanic healing

\footnotetext{
${ }^{357}$ Hughes, Ted. 'Orpheus'. The Tiger's Bones and Other Plays for Children. New York: Viking. 1974. 106-7. Hereafter referred to as: 'Orpheus'.

358 'Orpheus'. 107

359 'Orpheus'. 107
} 
ritual to resolve the grief and guilt caused by Plath's suicide. The 'song' of Birthday Letters conjures Plath back to life by recovering her voice, and by removing her words from the discourses that have dismembered them. In this way, his 'exploitation' of the Orpheus and Eurydice myth becomes a cathartic ritual of healing that allows him to translate his memories and conclusions into a meaningful pattern that concludes with the positive image of rebirth in her writings and that resists "contamination" from the discourses surrounding himself and Plath.

Hughes's notion of the poet as a shaman who is responsible for the health and well-being of his tribe reflects Aristotle's idea of poetry as a healing cathartic force. In describing Hughes's journey to recover Plath's lost spirit and to restore her spirit to its proper resting place in the land of the dead, Birthday Letters also has a cathartic effect upon the participating audience, as Hughes said in his essay 'Regenerations':

The results, when the shaman returns to the living, are some display of healing power, or a clairvoyant piece of information. The cathartic effect on the audience, and the refreshing of their religious feeling, must be profound. ${ }^{360}$

The tragic drama of Birthday Letters is cathartic in that it allows its audience to cleanse themselves from unclean influences, such as after the breaking of a taboo. In his Poetics, Aristotle argued that tragedy provides the audience with events that evoke pity and fear and enable the audience to purge these negative emotions safely. This explained for Aristotle why the audience finds it pleasurable to witness tragic action. ${ }^{361}$

Hughes described the shaman's main work as being "to guide a dead soul to its place in death, or back into life." ${ }^{362}$ In this sense, his cathartic journey as Orpheus in Birthday Letters is a shamanic quest to recover Plath's presence and to face the accusations made in her writings and to make peace with her. Birthday Letters attempts to break the cycle of vengeful dismemberment and rebirth that occurs through Plath's

\footnotetext{
360 'Winter Pollen', 57.

${ }^{361}$ Hutton, James. Trans. Aristotle's Poetics. New York: W.W. Norton, 1982. 50.

362 'Winter Pollen'. 57.
} 
poems and replace this with a more conciliatory life-affirming image of her, purged of the violence that destroyed her and those around her.

After Birthday Letters won the Forward Book of Poetry Prize in 1998, Hughes commented that the sequence was a private dialogue with Plath:

My book Birthday Letters is a gathering of the occasions on which I tried to open a direct, private, inner contact with my first wife - not thinking to make a poem, thinking mainly to evoke her presence to myself, and to feel her there listening. Except for a handful, I never thought of publishing these pieces until this last year - when quite suddenly I realized I had to publish them, no matter what the consequences. $^{363}$

Hughes's primary motivation in writing the Birthday Letters poems was, then, to achieve an imaginative resurrection of Plath in order for him to re-establish the dialogue that was cut short by her suicide. The imaginative effort of making "inner contact" with Plath, of "evoking her presence", was to enable Hughes to tell his own story, seek her understanding for his 'failure', contend with her characterisation oh him and to "feel her there listening".

In the drama of Birthday Letters, in order to resurrect Plath, Hughes goes into the underworld, as Orpheus, and asks the residing god there, "Prince Otto", 364 for the release of Plath's soul. This occurs in 'A Picture of Otto', a poem that echoes the soldier's encounter with his German enemy in Owen's 'Strange Meeting'. 'A Picture of Otto' recalls Plath's poem 'Daddy' in which she evokes her dead father's presence from a photograph of him standing in front of a blackboard:

You stand at the blackboard, daddy

In the picture I have of you,

\footnotetext{
363 'Ariel's Gift'. 22.

${ }^{364}$ Hughes advised that he and Plath used a Ouija board in the late 1950's and made contact with a spirit called "Prince Otto" who "was said to be a great power in the underworld" in: 'Winter Pollen'. 180.
} 
A cleft in your chin instead of your foot

But no less a devil for that, no not

Any less the black man who

Bit my pretty red heart in two.

(SPC.223-4)

This photograph of Otto (see Appendix 4) is the image Hughes refers to in his poem as having evoked Otto's presence into his and Plath's lives. Hughes describes Otto's shock at finding himself "conjured" face to face with Hughes in Plath's poem 'Daddy':

A big shock for so much of your Prussian backbone

As can be conjured into poetry

To find yourself so tangled with me -

Rising from your coffin, a big shock

To meet face to face in the dark adit

Where I have come looking for your daughter.

Hughes enters the "dark adit" of the underworld to meet Otto face to face, and make peace with his rival and establish their similarities and differences, as in Owen's 'Strange Meeting', finding that, in the mythopoeic terms of Plath's poems they are connected by their "occult guilt":

Your ghost inseparable from my shadow

As long as your daughter's words can stir a candle.

She could hardly tell us apart in the end.

Addressing Otto, Hughes accepts his "occult guilt" and concedes that they cannot be separated in this hell but must remain there perpetually conflated and "inseparable" in the mythic drama of her poems: 
I understand - you never could have released her.

I was a whole myth too late to replace you.

This underworld, my friend, is her heart's home.

Inseparable, here we must remain,

Everything forgiven and in common -

Not that I see her behind you, where I face you,

But like Owen, after his dark poem,

Under the battle, in the dark catacomb,

Sleeping with his German as if alone.

(BL. 193)

Hughes's acceptance of his fate to remain in hell with Otto Plath has led Linda Bundtzen to suggest that Hughes is unsuccessful in his quest into the underworld to free Plath from her myth:

Hughes's loss is depicted as irreparable, his grief implacable, and his longing unappeased by sacrifice. Only through the historical process of remembering important moments in their marriage and then permitting them to fade does Birthday Letters complete the process of healing grief. ${ }^{365}$

Sagar has also suggested that Hughes, like Orpheus, is unsuccessful in his quest in Birthday Letters and that all he can recover are "the memories of joys, births and indestructible love", which are nevertheless "a healing gift." "366 However, in the drama of Hughes's 1970 play 'Orpheus', we saw that Hughes had accepted that, like Orpheus, he could never recover Plath from the underworld but that he could recover her voice.

In 'A Picture of Otto', Hughes offers the self-sacrifice he was unwilling to make in 'Epiphany' by remaining with Otto in the underworld with "Everything forgiven and in

365 'Mourning Eurydice'. 462.

366 'The Laughter of Foxes'. 86. 
common" (BL.193). In doing so, he frees Plath from her destructive attachments to both himself and her father and releases her from the destructive cycle of death and rebirth described in her mythic poems. Plath's release is dramatised by a sleight of hand. Although Hughes advises Otto "I have come looking for your daughter" he also points out, "Not that I see her behind you, where I face you" (BL.193). The significance of this removal of Plath from the underworld and of Hughes's imaginary sacrifice in remaining in hell with Otto can not be overstated. As Orpheus, Hughes must undergo the shaman's "magical death, then dismemberment, by a demon or equivalent powers" in order to "guide a dead soul to its place in death or in life". 367

In a 1976 radio interview at the Adelaide Festival, Hughes discussed 'The Wound', another drama based on a journey into the underworld. Hughes said that he had dreamed the play "from beginning to end" and interpreted it as "a sort of Celtic Bardo Thodol" (More commonly known in the West as 'The Tibetan Book of the Dead'). During the discussion, Hughes said that his play 'The Wound' had faithfully reproduced his dream in all but one respect; he had changed the ending of his dream so that the hero survives in the play because he was superstitious about leaving the hero in hell:

Hughes: That was faked. That was not part of the dream.

Interviewer: Of course, I know, but that's in fact the end.

Hughes: I mean, I put that on - just to get him out of it. In the dream - in the film of the dream, he didn't come out. [Hughes described the dream as being recalled in images as in a film]

Interviewer: Why did you put that on?

Hughes: $\quad$ Because I didn't want to leave him in hell [laughs]. I had to bring him back - for my sake. I wanted to end it upbeat, rather than downbeat - simply - so I rigged the end of it.

Interviewer: Is that rather rigged?

Hughes: $\quad$ Rigged? Yes.

Interviewer: It's like a Hollywood happy ending.

367 'Winter Pollen'. 56. 
Hughes: Yes.

Interviewer: Do you still feel that was the right way to end it?

Hughes: Well, I'm just superstitious about ending works downbeat, because if they're very involved with your private psychology, where the work ends - that's where you end, too. You've taken yourself through this process and it's very important that you bring yourself out of a bad process. And if you stop the work at the bottom, in the bad part of the process, that's where, inwardly, you stop. That's just a superstition. So I like to bring them out in the end. ${ }^{368}$

In 'A Picture of Otto', by remaining in the underworld with Otto, Hughes offers himself as a sacrifice to end the rivalry between himself and Otto for possession of Plath, and in doing so, he frees Plath from Hell and effectively ends the cyclic drama of death and rebirth in her myth.

Hughes's imaginary sacrifice in 'A Picture of Otto' can be seen as linked with the ritual murder of the sacred king in the Goddess myth in the poem 'The Offers', which appeared in Howls and Whispers (1998), a book of eleven poems addressed to Plath that were originally part of the Birthday Letters sequence. ${ }^{369}$ Howls and Whispers was released in a limited edition of 110 copies, illustrated by Leonard Baskin but became more widely available in Hughes's Collected Poems in 2003.

In 'The Offers', Hughes describes three Hughes encounters with Plath following her death. The first time he sees her he is on the London Underground and, without speaking to her, he gets off the train at Chalk Farm Bridge, the very location where he refuses the offer of a fox-cub in the Birthday Letters poem 'Epiphany'. Plath next appears at Court Green, where she appears in the guise of another woman who resembles her and even shares her birth date. Hughes initially dismisses this "hallucination" as a coincidence but

\footnotetext{
368 Ted Hughes: The Wound. Transcript of the interview with Ted Hughes from the Adelaide Festival, March 1976.

${ }^{369}$ Howls and Whispers includes the poem 'The Laburnum', which was part of the original Birthday Letters sequence submitted to Hughes' publisher at Faber, Christopher Reid.
} 
before her third appearance he has learned to accept that Plath's "return to the living" has been made possible because he is "a hostage stopped / In the land of the dead" being held as "bail" for her release (THC.1183). When she returns for the third and final time in 'The Offers', she appears behind Hughes, suddenly, as he steps into the bath. Again, as in the Birthday Letters poems, she is described as having a blue aura; the blue jewel that is her positive life-affirming aspect and is connected with rebirth in Birthday Letters:

\section{Less and less}

Did I think of escape.

Even in my dreams, our house was in ruins.

But suddenly - the third time - you were there.

Younger than I had ever known you. You

As if new made, half a wild roe, half

A flawless thing, priceless, facetted

Like a cobalt jewel. You came behind me

(At my helpless moment, as I lowered

A testing foot into the running bath)

And spoke - peremptory, as a familiar voice

Will startle out of a river's uproar, urgent,

Close: 'This is the last. This one. This time

Don't fail me.'

(THC.1183)

Here, at the close of 'The Offers', Hughes is again describing offering Plath the selfsacrifice he was unable to make in 'Epiphany', which frees her from the underworld and allows him to achieve redemption for his earlier failure. In depicting himself in this "helpless moment", as he stands with one foot in the bath, Hughes connects himself explicitly with the sacred king who is sacrificed for the moon goddess in ancient myth and ritual. The death of the sacred king, as we have seen - is necessary for the rebirth of the goddess and as Graves observed in The White Goddess: "every Muse-poet must, in a sense, die for the Goddess whom he adores just as the [sacred] king must die."370

\footnotetext{
370 'The White Goddess'. 489.
} 
Furthermore, Graves described the sacred king's ritual murder as, according to some traditions, as taking place while he is taking a bath:

The bath in the story of Llew's murder is, as I have said, familiar. Sacred kings often meet their end in that way: for example, Minos the Cretan Sun-god at Agrigentum in Sicily at the hands of the priestess of Cocalus and her lover Daedalus; and Agamemnon, the sacred king of Mycenae, at the hands of Clytemnestra and her lover, Aegisthus. It is a lustral bath of the sort that kings take at their coronation... ${ }^{371}$

The sacred king is ritually sacrificed as he places one foot into his bath because traditionally, as some of the myths still explain, he cannot be killed when on land or water and can only be killed when he is between these two places. This tradition also explains the drama of Plath's 'Purdah', in which she alludes to the murder of Agamemnon: ${ }^{372}$

... at his next step

I shall unloose

I shall unloose -

From the small jeweled

Doll he guards like a heart -

The lioness,

The shriek in the bath,

The cloak of holes. (SPC.243-4)

'The Offers' provides another more explicit description of the imaginative self-sacrifice described in 'A Picture of Otto', in which Hughes takes Plath's place in the Underworld

\footnotetext{
371 'The White Goddess'. 322.

${ }^{372}$ Hughes's translation of Aeschylus's Oresteia was published posthumously in 1999.
} 
to facilitate her rebirth and to earn the imaginative redemption and forgiveness that Plath's suicide denied him.

In the ancient myths that follow Orpheus's progress after his journey into the underworld, he is punished for continuing to mourn Eurydice by being torn apart by a group of frenzied women who cast his still singing head into the river Hebrus and is carried to Lesbos where he is buried and at last reunited with Eurydice. For Hughes, this part of the story reflected his own 'magical death', his own spiritual dismemberment by Plath's feminist readers. A fate he saw anticipated in Plath's poem, 'Burning the Letters', which as Middlebrook has pointed out, Plath composed on the verso drafts of Hughes's 'The Thought-Fox':

The dogs are tearing a fox. This is what it is like -

A red burst and a cry

That splits from its ripped bag and does not stop

With the dead eye

And the stuffed expression, but goes on

Dyeing the air,

Telling the particles of the clouds, the leaves, the water

What immortality is. That it is immortal.

(SPC.205)

Earlier in the Birthday Letters narrative, in 'Setebos', Hughes hears Plath cry: "Who has dismembered us" (BL.133) as their marriage fails and, as he hides under a gabardine, he appears to overhear an answer in "hearing the cry / Now of hounds" (BL. 133). The combination of these images in 'Setebos' recall respectively Plath's 'Event' and 'Burning the Letters' in which she describes Hughes's dismemberment and links it with the sacrifice of the sacred king described in the myth of Actaeon. In this version of the myth, 
the sacred king Actaeon was torn apart by his own hunting hounds, after Diana turned him into a stag because he looked on her as she bathed naked and offended her. ${ }^{373}$

In the penultimate Birthday Letters poem 'The Dogs Are Eating Your Mother', which is addressed to Plath's children, Hughes turns the drama of dismemberment described in Plath's poems into a ritual sacrifice that guarantees her rebirth. This poem records the arrival of the hounds Hughes hears approaching in 'Setebos' and reveals these dogs as the biographers and critics that cruelly tear Plath's dead body apart in order to satiate their own appetites:

Remember the lean hound

Running up the lane holding high

The dangling raw windpipe and lungs

Of a fox? Now see who

Will drop on all fours at the end of the street

And come romping towards your mother,

Pulling her remains, with their lips

Lifted like dog's lips.

In the first four lines, Hughes describes his true self and his creative voice ("The dangling raw windpipe and lungs... of a fox") as being ripped apart by the dogs, as in Plath's 'Burning the Letters'. Hughes does not challenge this punishment but, again, appears to offer the image of his dismemberment as a sacrificial offering as reparation for his failure. But the narrative of the poem then moves on to describe the dogs' disinterment and dismemberment of Plath's dead body by her critics and biographers. Hughes warns his children that attempting to recover their mother from this desecration is futile, and, in doing so, offers a dramatic explanation for his refusal to engage with Plath's critics and biographers:

\footnotetext{
${ }^{373}$ Graves points out that the sacred king was often made to wear antlers or horns before being murdered and replaced by his rival; a trace of this tradition has survived in the image of the cuckold wearing horns or antlers.
} 


\section{Protect her}

And they will tear you down

As if you were more her.

They will find you every bit

As succulent as she is. Too late

To salvage what she was

I buried her where she fell.

'The Dogs Are Eating Your Mother' expresses Hughes's feelings of helplessness, in attempting to protect Plath from the "fantasies" of her critics and biographers, who, having finished with her body, "Even / Bite the face off her gravestone, / Gulp down the grave ornaments, [and] swallow the very soil" (BL.195). In one of his letters to Stevenson, Hughes described protecting Plath's memory from those who wanted to attack Plath to protect him as being "like trying to protect a fox from my own hounds while the fox bit me." ${ }^{374}$ However, in 'The Dogs Are Eating Your Mother', he suggests to his children that they imaginatively transform this cruel dismemberment into a ritual performed "with holy care" to ensure her rebirth in the place where all pure souls head the sun, as in 'Ariel' and 'Fever':

\section{Let them}

Jerk their tail stumps, bristle and vomit

Over their symposia.

\section{Think her better}

Spread with holy care on a high grid

For vultures

To take back into the sun. Imagine

These bone crunching mouths the mouths

That labour for the beetle

Who will roll her back into the sun.

\footnotetext{
${ }^{374}$ Ted Hughes quoted in 'The Silent Woman'. 143.
} 
The imaginative dismemberment in 'The Dogs Are Eating Your Mother' can be seen as the necessary ritual in the sequence as a whole to guarantee the rebirth described in the book's next and final poem 'Red'. In 'Red', Hughes recalls the bloody imagery that appeared to seep from Plath's poetry into their lives and home:

Red was your colour.

If not red, then white. But red

Was what you wrapped around you.

Blood-red. Was it blood?

Was it red-ochre, for warming the dead?

Haematite to make immortal

The precious heirloom bones, the family bones.

(BL.197)

Hughes questions whether Plath's preoccupation with the colour red was connected with the worship of her dead father. Her redecoration of Court Green becomes a metaphor for the way in which the mythic vision of her poems imposed itself on their everyday life and home:

When you had your way finally

Our room was red. A judgement chamber.

Shut casket for gems. The carpet of blood

Patterned with darkening, congealments.

The curtains - ruby corduroy blood,

Sheer blood-falls from ceiling to floor.

The cushions the same. The same

Raw carmine along the window seat.

A throbbing cell. Aztec altar - temple.

In Her Husband, Middlebrook comments that Plath decorated Court Green entirely with new red carpet and that her favoured decorating colours corresponded with the colours that represented the White Goddess in her triple aspect: 
Plath couldn't sit still. She bought a used sewing machine and supplied herself with many yards of red corduroy for the upholstery, curtains, pillows, Frieda's bedspread. Red, white and black were her standard decorating colours: vermillion, she said, was her "color tonic." Her most self-indulgent purchase for the house was that fine red Wilton carpet she installed in her own study, but she also ordered equally vivid but less expensive red carpet for the hall runners and stairs, and a good figured carpet for the living room, with red the background colour. $^{375}$

In 'Red', Hughes catalogues Plath's red furnishings relentlessly in order to portray the obsessive nature of her preoccupation with the colour that is connected with her true self in the mythic schema of her poems. In describing Plath's room as a "judgement chamber" and as an "Aztec altar" and in repeatedly using the word "blood", Hughes points out, as he does in 'Suttee', that the rebirth Plath achieves would involve a blood sacrifice. After surveying the room's furnishings, Hughes shifts his attention to flowers that could be seen from the room window. Hughes describes the roses and salvias he sees from the window in the same subjective terms as Plath's poems. The red flowers are "like blood lobbing from a gash" and "the heart's last gouts" (BL.197). In this way, Hughes recalls the flowers of Plath's 'Poppies in July' as “A mouth just bloodied / Little bloody skirts" (SPC.203) and in 'Poppies in October', which call to her mind "the woman in the ambulance / Whose red heart blooms through her coat so astoundingly" (SPC. 240). Hughes also has Plath dressed in red; her "velvet long full skirt, a swathe of blood" and her "lips a dipped, deep crimson" (BL.197). In this way, he illustrates how her subjective imaginative psychological drama begins to seep into Plath's home and is how her active identity is consumed by her myth while she attempts to escape "the death who had already donned [her] features" (BL.110).

In her poem 'Kindness', Plath wrote, "The blood jet is poetry / There is no / Stopping it" (SPC.270); in 'Red' Hughes suggests that the dramatic terms of Plath's

375 'Her Husband'. 144. 
mythic poems demanded a blood-sacrifice, consuming her personal identity and history, her myth demanded the sacrifice of her active life. "Everything you painted you painted white", Hughes recalls, "Then splashed it with roses, defeated it, / Leaned over it, dripping roses, / Weeping roses, and more roses" (BL.198). Hughes's description metonymically links his image of Plath's painting their home (as in the earlier poem 'Totem') with an image of her leaning over her white pages and filling them with her sanguine poems. Then, Hughes introduces a shift, by pointing out that among the "dripping roses" Plath sometimes painted "a little bluebird" (BL.198). This image returns the reader to the "eight-year-old's bluebird" (BL.163) of his earlier poem 'Totem', and which Hughes clearly associates with Plath's childhood prior to the death of her father. When blue appears in Plath's poems, it is linked with images of innocence and purity, the newborn baby, for example, and Mary the mother of Christ ('Heavy Women', 'Three Women', 'Nick and the Candlestick' (SPC.158, 181, 240). In 'Red', Hughes suggests that blue was a life-affirming positive cathartic colour for Plath, and the Birthday Letters sequence closes this way:

Blue was better for you. Blue was wings.

Kingfisher blue silks from San Francisco

Folded your pregnancy

In crucible caresses.

Blue was your kindly spirit - not a ghoul

But electrified, a guardian, thoughtful.

In the pit of red

You hid from the bone-clinic whiteness.

But the jewel you lost was blue. (BL. 198)

In the final word of Birthday Letters Hughes replaces the bloody colour red, which saturated Plath's poems and seeped into their lives with the life-affirming colour blue, which he connects with "Kingfisher blue silks" that "folded your pregnancy". "The 
blue's a jewel" (SPC.238) Plath had said in 'The Tour' and Hughes suggests the blue jewel is the life-affirming aspect of Plath that he elsewhere connects with the fertility goddess 'Isis', or the childbearing creative aspect of the Mother Goddess. Blue is the colour of the "waters off beautiful Nauset" (SPC.222), it is Plath's "vision of the sea", which she describes as "the clearest thing I own" in 'Ocean 1212-W", 376 and which is the "salty globe of blue" that is Plath's "periscope lens" in 'The Prism':

I still have it. I hold it -

'The waters off beautiful Nauset'.

Your intact childhood, your Paradise

With its pre-Adamite horse-shoe crab in the shallows

As a guarantee, God's own trademark.

I turn it, a prism, this way and that.

This way I see the filmy surf-wind flicker

Of your ecstasies, your visions in the crystal.

The blue jewel of Plath's childhood is the healing vision that Hughes, as Orpheus, recovers in the journey of Birthday Letters; this is the consoling vision of Plath's own words. The final flash of blue returns the attentive reader to the blue hairband Hughes steals from Plath during their first encounter in the Birthday Letters poem 'St Boltoph's' in which Hughes describes taking Plath's “blue headscarf” (BL.15) from her. In her Journals, Plath described it as "my lovely red hairband scarf” specifically stating it was a favourite of hers "whose like I shall never again find". 377 Hughes edited Plath's Journals and would have been familiar with her description of their first meeting in particular, so his description of the hairband as blue is a blatant contradiction that unsettles the reader's confidence in having the facts to judge either his or Plath's version of events. However, Hughes is not simply challenging Plath's subjectivity here. Symbolically, he is accepting responsibility for stealing this life-affirming aspect of Plath, in being "midwife" to the fiery rebirth he describes in 'Suttee'. In their poetry, Hughes and Plath discovered the

\footnotetext{
376 'Johnny Panic and the Bible of Dreams'. 116.
}

377 'Winter Pollen'. 212. 
ability to transform objective reality through the imaginative subjective visions they created. At the close of Birthday Letters' infernal journey, Hughes attempts one final act of transformation, an act of purification in the reader's imagination - the place where all myths are sustained. In looking back, Hughes, like Orpheus, always loses Plath, but by recovering her words he manages to rescue that aspect of her that her myth was unable to consume. In leading her back into the light, Hughes purges himself, and the reader, for the roles we perform in perpetuating their myth. 


\section{Epilogue}

In The Laughter of Foxes, Sagar has suggested that Birthday Letters is not part of Hughes's main achievement. Nevertheless, a survey of Hughes's wider writings suggests that, in the years following Plath's suicide, he was privately developing the symbols and drama that would frame the vision of his final book of poems in Birthday Letters. During the writing of this thesis it became clear to me that the mythopoeic vision of Birthday Letters is not confined to the eighty-eight poems of the sequence, but can be seen, and better understood, in terms of Hughes's wider writings. A comprehensive survey of Hughes's oeuvre is beyond the scope of the present study, however, I include the example of his short story 'The Deadfall' here to indicate how the symbols and drama in his writings call out to one another, and to suggest where other scholars might take up and expand on the present study.

In 'exploiting' Graves's 'Theme', the goddess myth, to cure the wound inflicted by Plath's suicide, Hughes achieved a strong sense of psychological release. He described the effect of writing the sequence in a 1998 letter to Seamus Heaney:

The realisation that I had to rid myself of the whole log-jam pile-up - as a matter of urgency - dawned as I was doing the Shakespeare book... Then when I assembled my New Selected [Poems]... I thought of adding a good heap of these pieces - 30 or 40 maybe and started grooming \& trimming the most ragged to the most attractive. But Carol's sister was dying \& nursing her daily Carol was in no shape to deal with these extras. I managed to clear those few ... The rest I stuffed back into the sack. But they wouldn't stay. So I brought them back up \& wrote at them en masse for some time - not knowing what I'd end up with or where I'd end till suddenly between one day and the next - I realised that was it. I couldn't grasp the wholeness of it but I had the sensation of the whole load of long preoccupation dropping away separating itself and dropping away like a complete piece of fruit. The sense of 
being released from it was very strong and weird. I had huge quantities of little germinal notes - all suddenly obsolete. ${ }^{378}$

As he commented to Heaney, in 1994 Hughes had published eight of the Birthday Letters poems in his New Selected Poems ('Chaucer', 'You Hated Spain', The Earthenware Head', 'The Tender Place', Black Coat', Being Christlike', 'The God', and 'The Dogs Are Eating Your Mother'), but did not feel able to publish more while his wife, Carol, was dealing with her own personal difficulties. Nevertheless, after returning to the poems, he describes realising the poems were finished when he felt he had freed himself from his pre-occupation with his tragic past.

In 1994, Hughes's wrote 'The Deadfall' in response to a request for a story for Michael Morpurgo's collection of ghost stories for children, Ghostly Haunts. The story's narrator appears to be a younger version of Hughes; he is a young boy from Hebden Bridge who describes going out hunting with his older brother in Crimsworth Dene. This is a valley near Hardcastle Crags in Yorkshire where Hughes and his older brother Gerald used to hunt. When he published 'The Deadfall' as the first story in his collection of short fiction Difficulties of a Bridegroom, he described it as "an early experience of my own that filled the requirements" of Morpurgo's request but that contained "a few adjustments to what I remember" 379 Neil Roberts has pointed out that in a letter that Hughes wrote to his brother Gerald recalling the episode on which the story is clearly based, "Hughes makes no reference to the central incidents of the story". Roberts also points out that in an earlier draft of the story held in the archives at Emory University the protagonist appears to be a First World War veteran modelled on Hughes's father. Given the sixty years that had passed since Hughes recorded the events, and Hughes's own comments about making a "few adjustments" to the story, Roberts warns we should be wary of assigning autobiographical value to the story. ${ }^{380}$

\footnotetext{
378 'Emory'. Seamus Heaney Collection: Box 40 FF16. Letter from Ted Hughes to Seamus Heaney dated 1 January 1998. [Restricted]

379 'Difficulties of a Bridegroom'. ix.

${ }^{380}$ Roberts, Neil. Ted Hughes: A Literary Life. New York: Palgrave, 2006. 10.
} 
In the last chapter we saw that Hughes described his fables for children as being full of "psychic symbols" ${ }^{381}$ to help children make sense of their inner lives. In the next few pages I will be suggesting that 'The Deadfall' can be seen as a description of the cathartic psychological effect Hughes experienced in writing Birthday Letters. The short story can be interpreted as a symbolic drama in which Hughes describes how, in allowing himself to be led by Plath's voice, in responding to her words, he is able to lay her spirit to rest and release his creative life from his haunted past. In this sense, his comments about 'The Deadfall' relating to "an early experience that filled the requirements" of Morpurgo's request for a ghost story is less disingenuous than it might first appear.

After a preliminary introduction to the characters, the narrator of 'The Deadfall' describes going camping with his older brother. They spend a night sleeping under canvas and the following morning go out with a rifle in what the boy describes as a "new hunting ground" that was "so magically wild, secret and undisturbed" that he "was hoping for a record bag". ${ }^{382}$ Despite these high hopes, the boys do not see any game and "did not fire one shot" that morning. ${ }^{383}$ As they head back to their camp, they discover a farmer's deadfall trap:

Under the wall, on the wood side, a big flat stone like a flagstone, big as a gravestone, leaned outwards, on end. It was supported, I saw, by a manmade contraption of slender sticks. Tucked in behind the sticks, under the leaning slab, lay a dead woodpigeon, its breast torn, showing the dark meat. 'Gamekeeper's deadfall,' said my brother. It was the first deadfall I had seen set. I had read about them, made of massive tree trunks, used by trappers in the Canadian forests for bears, wolves, wolverines. My brother explained how it worked. How one light touch on the tripstick would collapse the support and bring the great stone slam down flat - on top of whatever was under it. ${ }^{384}$

\footnotetext{
${ }^{381}$ Letter from Ted Hughes to his brother Gerald Hughes quoted in 'Her Husband'. 98.

${ }^{382}$ Hughes, Ted. 'The Deadfall'. In: Morpurgo, Michael. (ed.) Ghostly Haunts. London: Pavilion Books, 1994. 17. Hereafter referred to as 'The Deadfall'.

383 'The Deadfall'. 18.

384 'The Deadfall'. 18.
} 
It is worth noting the young boy's description of the trap as being "big as a gravestone". ${ }^{385}$ To link this deadfall with Plath, we need only look to the second poem in Birthday Letters, 'Caryatids (1)', in which Hughes describes his first encounter with Plath, reading her poem, 'Three Caryatids Without a Portico':

What were those caryatids bearing?

It was the first poem of yours I had ever seen.

It was the only poem you ever wrote

That I disliked through the eyes of a stranger.

It seemed thin and brittle, the lines cold.

Like the theorem of a trap, a deadfall - set.

I saw that. And the trap, unsprung, empty.

The deadfall in Plath's poem, like that in 'The Deadfall' is still unsprung. However, unlike the young narrator of 'The Deadfall' who walks past the trap "warily" ("I didn't want the jolt of my tread to bring it down"), ${ }^{386}$ the young Hughes in Birthday Letters experiences "No stirring / Of omen" (BL.4) and walks straight into a situation where his clumsy actions could create a disaster:

In those days I coerced

Oracular assurance

In my favour out of every sign.

So missed everything

In the white, blindfolded, rigid faces

Of those women. I felt their frailty, yes:

Friable, like the mantle of a gas lamp.

But made nothing

Of that massive, starless, mid-fall, falling

Heaven of granite

385 'The Deadfall'. 18.

386 'The Deadfall'. 18. 
Stopped, as if in snapshot,

By their hair.

The young Hughes of Birthday Letters does not have the hindsight to recognise the poem's central image, which appears to be the White Goddess in her triple aspect, nor the "Heaven of granite" falling from the poem's unsprung deadfall trap. In the subsequent Birthday Letters poem 'Caryatids (2)', he describes how he and his friends step into the unsprung trap by composing a scathing review of the poem ("a dismemberment") in order to "spark a contact" with Plath:

We had heard

Of the dance of your blond veils, your flaring gestures, Your misfit self-display. More to reach you

Than to reproach you, more to spark

A contact through the see-saw bustling

Atmospherics of higher learning

And lower socialising, than to correct you

With our archaic principles, we concocted

An attack, a dismemberment, laughing.

We had our own broadsheet to publish it.

In attacking Plath's poem, Hughes steps under the deadfall, ensuring they meet at the St Boltoph's party, and placing himself in a situation where "one light touch on the tripstick would collapse the support and bring the great stone slam down flat". 387

In 'The Deadfall', after discovering the trap, the boys spend the rest of the day hunting without success. As the day grows dark they return to the deadfall and find it is still unsprung before returning to their tent. After sleeping for some time the young narrator is awoken by a woman's voice who apparently needs help (in the same way that the younger "sleepwalking" Hughes is awoken in Birthday Letters by finally interpreting

387 'The Deadfall'. 18. 
Plath's words). Without waking his older brother, the boy follows the voice and finds "a small old woman, with a peculiar bonnet on her head and a long shawl." The woman asks the boy to follow her, saying: "Come out. Quickly. There's been an accident". 388 Following her, the boy is led back to the woods and finds himself back at the deadfall trap:

Then I smelt the rich, powerful smell. With a shock, I remembered I had come right up to the deadfall. The great slab of stone had fallen. Beside it sat a wellgrown fox-cub, staring up at me, panting. As I took this in, the cub suddenly started again, tugging and bouncing, jerking and scrabbling, without a sound, till again it crouched there, staring up at me, its mouth wide open, its tongue dangling, panting. I could see now that it was trapped by one hind leg and its tail. They were pinned to the ground under the corner of the big slab. The smell was almost overpowering, thick, choking, almost liquid, as if concentrated liquid scent had been poured over me, saturating my clothes and hands. I knew the smell of fox - the overpowering smell of frightened fox. ${ }^{389}$

Like the fox-cub in the Birthday Letters poem 'Epiphany', the fox-cub in 'The Deadfall' is in distress and needs the narrator's help. In describing the fox's powerful smell Hughes connects it with the fox in 'Thought-Fox', which is apprehended as a "sudden sharp hot stink of fox" (THC.21), and which, as we have seen, we can see as a symbol of Hughes's poetic inspiration and his authentic self. In 'Epiphany' Hughes “failed" (BL.115) the fox-cub in refusing to assist it because he believes he cannot accommodate it in his domestic situation. However, in 'The Deadfall', the young narrator helps the fox-cub, despite realising that he cannot "keep it":

My first thought was to catch the cub and try and keep it alive. But how could I hold it and at the same time lift the slab? It was a desperate, ferocious little thing. I could have wrapped it in my jersey, knotting the arms round it. But I didn't

\footnotetext{
388 'The Deadfall'. 21.

389 'The Deadfall'. 22-4.
} 
think of that. As I put my fingers under the other corner of the slab, the cub snapped its teeth at me and hissed like a cat, then struggled again, jerking to free itself. With all my strength I was just able to budge the slab a fraction. But it was enough. As the slab shifted, the cub scrabbled and was gone - off down the wood like a rocket. ${ }^{390}$

After freeing the fox-cub the boy looks around for the old woman who had led him there and notices that she had gone: "disappeared". Unable to lift the stone by himself, he goes back to his tent and tells his brother what has happened. On the following day, the two boys return to the deadfall and the older brother lifts the stone slab. Beneath it, they find a dead adult vixen. Pitying the dead fox, the older brother tells the narrator "This fox escaped" and together they bury it in the earth. As the older brother digs a grave with an axe ${ }^{391}$ the boy examines the dead animal's body:

I crouched beside the work, watching the hole and looking at the fox. I had never examined a fox. It was so astonishing to see it there, so real, so near. When I lifted its eyelid, the eye looked at me, very bright and alive. I closed it gently and stroked it quite shut. ${ }^{392}$

We can link this dead adult fox with Plath because of another Birthday Letters poem. In 'Fishing Bridge', Hughes describes himself being led through a labyrinth by a "voice" that is presumably his poetic inspiration. However, at the centre of the labyrinth he only finds Plath's dead body. As he bows over her, he describes lifting her eyelids lifts to look into her eyes:

The voice held me there, by the scruff of the neck,

And bowed my head

Over the thing we had found. Your dead face.

\footnotetext{
390 'The Deadfall'. 24.

${ }^{391}$ In Plath's poem 'Words' she wrote that words are "Axes / After whose stroke the wood rings" (SPC.270).

392 'The Deadfall'. 26.
} 
Your dead lips, dry, pale. And your eyes

(As brown-bright when I lifted the lids,

As when you looked across that incandescence)

Unmoving and dead.

In 'Fishing Bridge', Hughes's inspiration only leads him to grief and despair as he is trapped in the labyrinth that surrounds Plath's suicide. However, in 'The Deadfall', we can see that in facing this tragedy, in addressing Plath directly in the Birthday Poems, 'in looking her directly in the eye' and in laying her to rest, Hughes removes her from the reach of the dogs of 'The Dogs Are Eating Your Mother' and frees his psychic life.

The young boy of 'The Deadfall' sets the fox-cub free and is rewarded for burying the dead fox the with a small ivory image of a fox, which he finds in the soil as he is pushing loose earth over her body. The boy is so startled by what he finds he does not tell his brother and keeps it to himself. Given the mythopoeic drama we have already considered, in the previous chapters, and the parallels between 'The Deadfall' and Birthday Letters, it is difficult to not read this short story allegorically; seeing the dead vixen of 'The Deadfall' as Plath, and the fox-cub as Hughes's poetic self. As we saw in the last chapter, in following Plath's voice in Birthday Letters, Hughes recovers a positive life-affirming image that frees his creative life from the circumstances of her death. In doing so, he is rewarded by a private treasured healing image, an ivory fox. Connections such as these suggest that a wider mythopoeic study of Hughes's apparently unrelated works would uncover other private treasures hidden in full view of the reader. 
10 Bibliography

\section{Appendices}

Appendix 1: Goddess of Willendorf. Limestone. 20,000 - 18,000 BC, height 4.75 in $(11 \mathrm{~cm})$. Austria

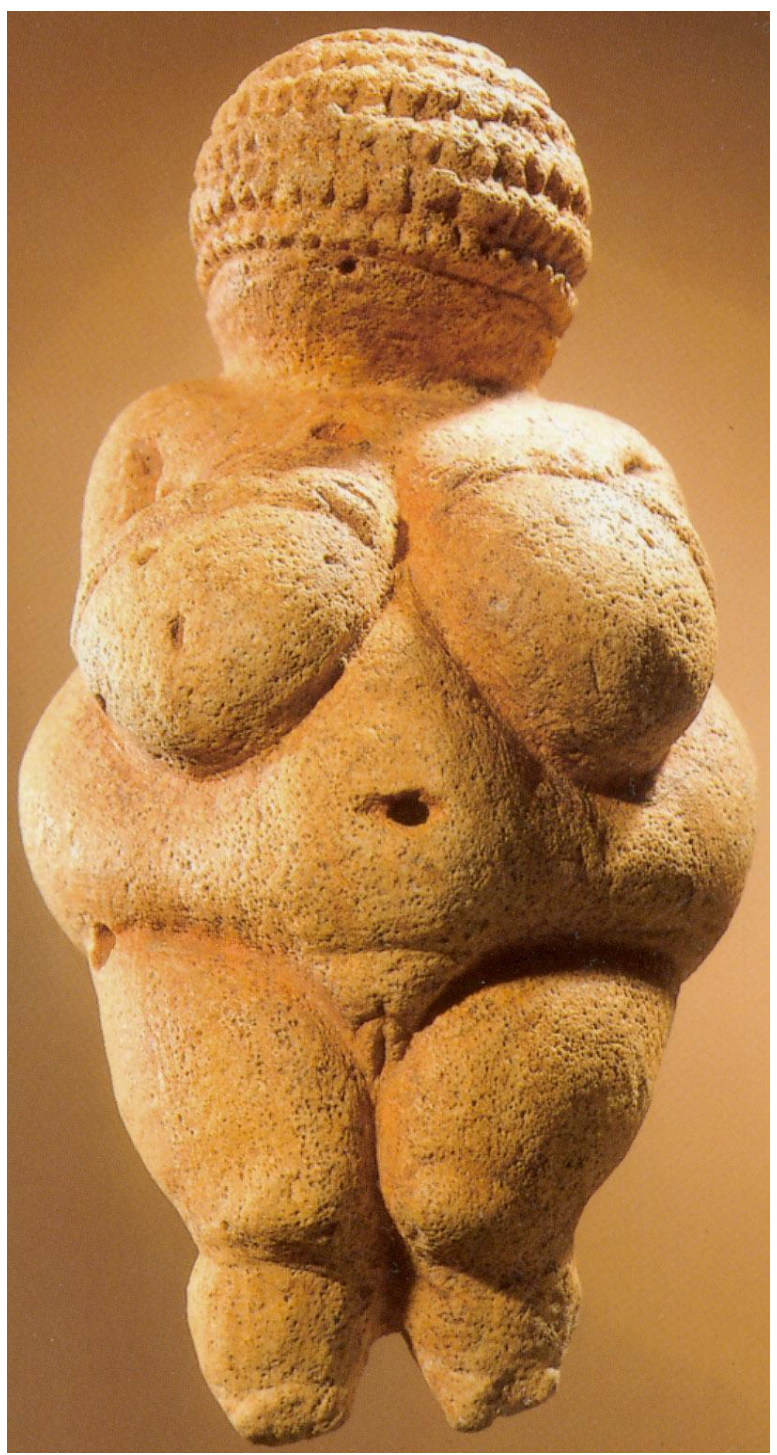


Appendix 2: Goddess of Laussel; rock carving, 22,000 - 18,000 BC, height 17 in. $(43 \mathrm{~cm})$. Dordogne, France.

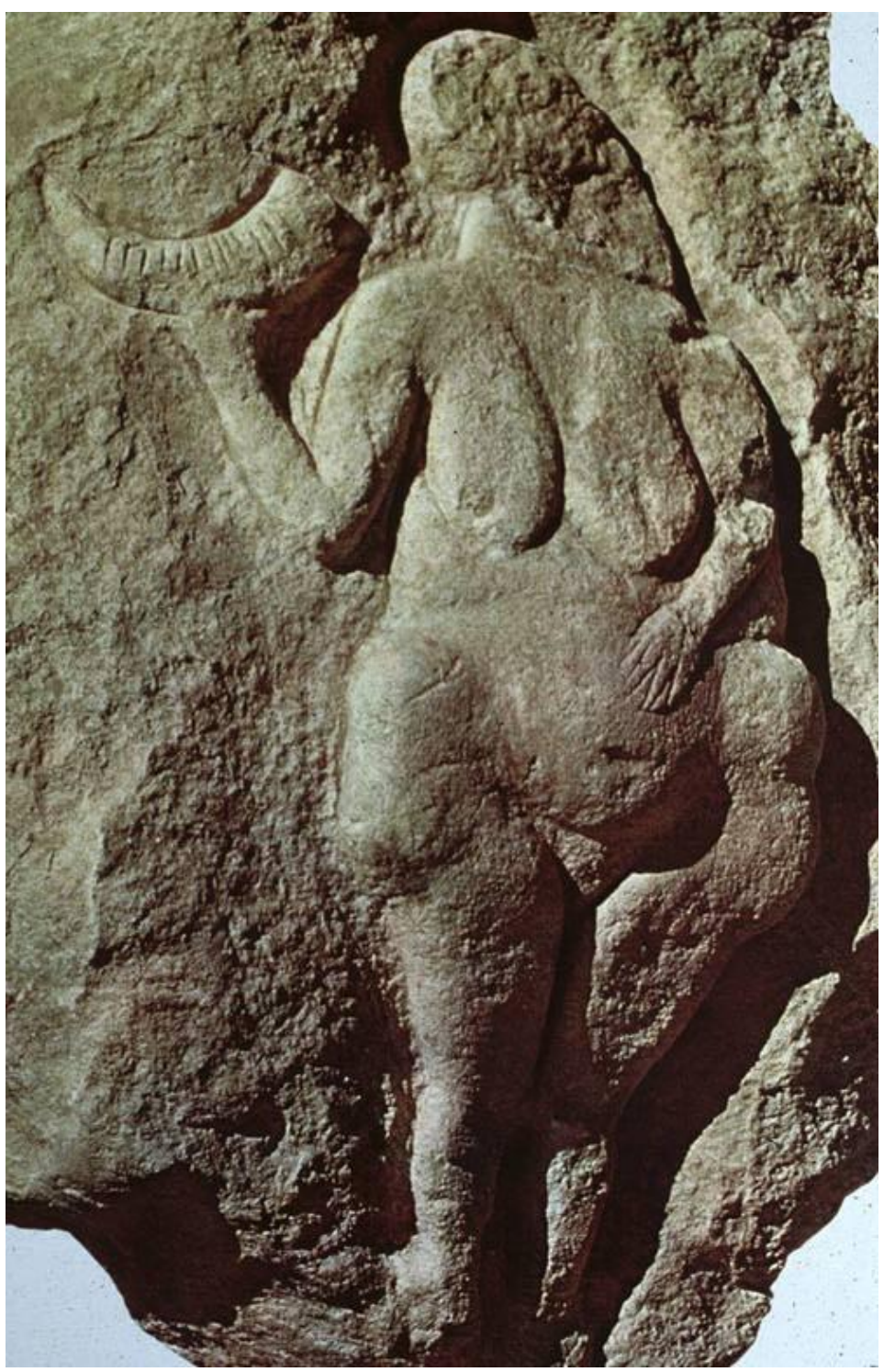




\section{Bibliography}

Appendix 3: reproduction of poster of Isis hung in Plath's home.

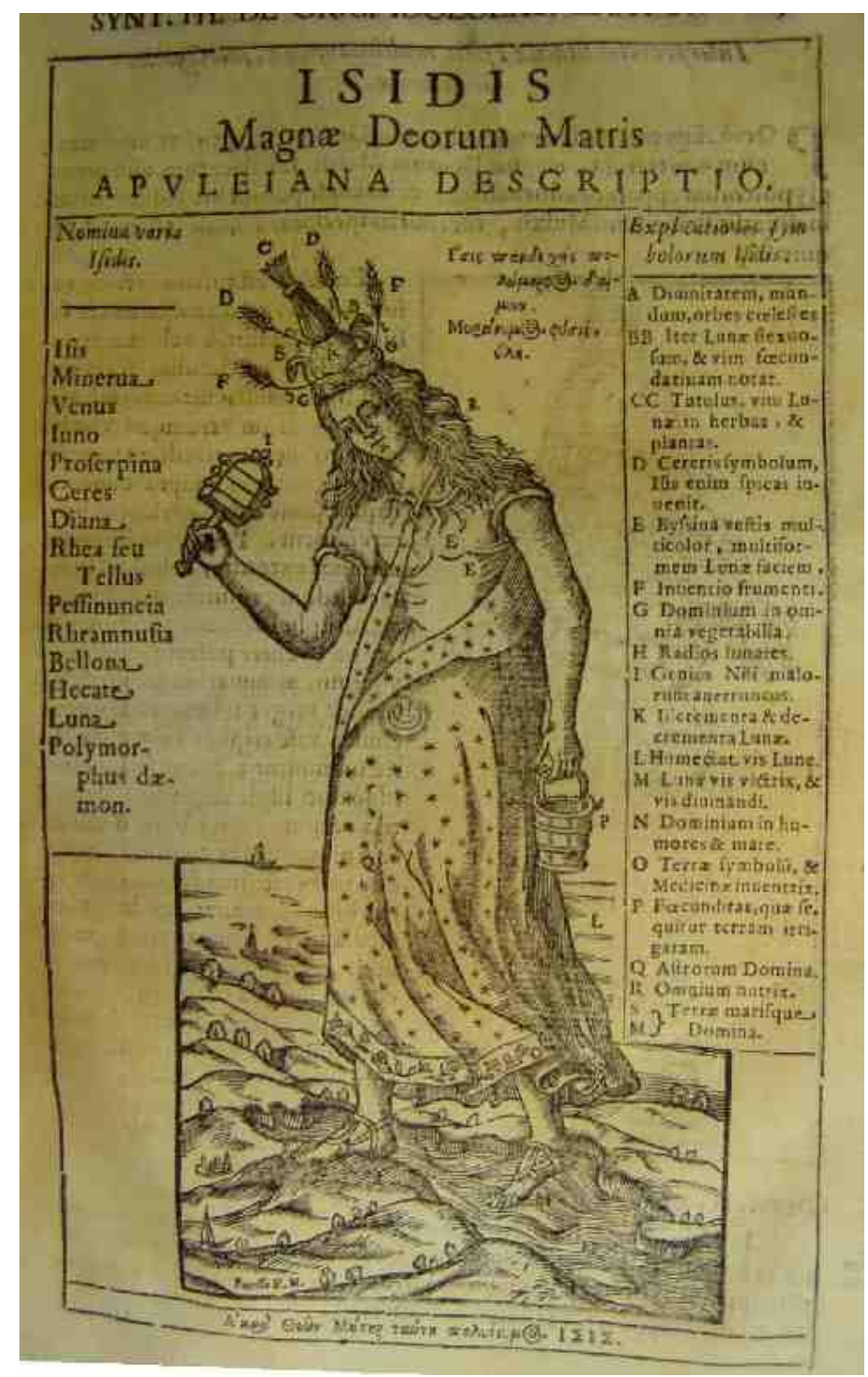


Appendix 4: A picture of Otto Plath at the blackboard in 1930. Wagner, Erica. Ariel's Gift: Ted Hughes, Sylvia Plath and the Story of Birthday Letters. London: Faber, 2000. 108-109.

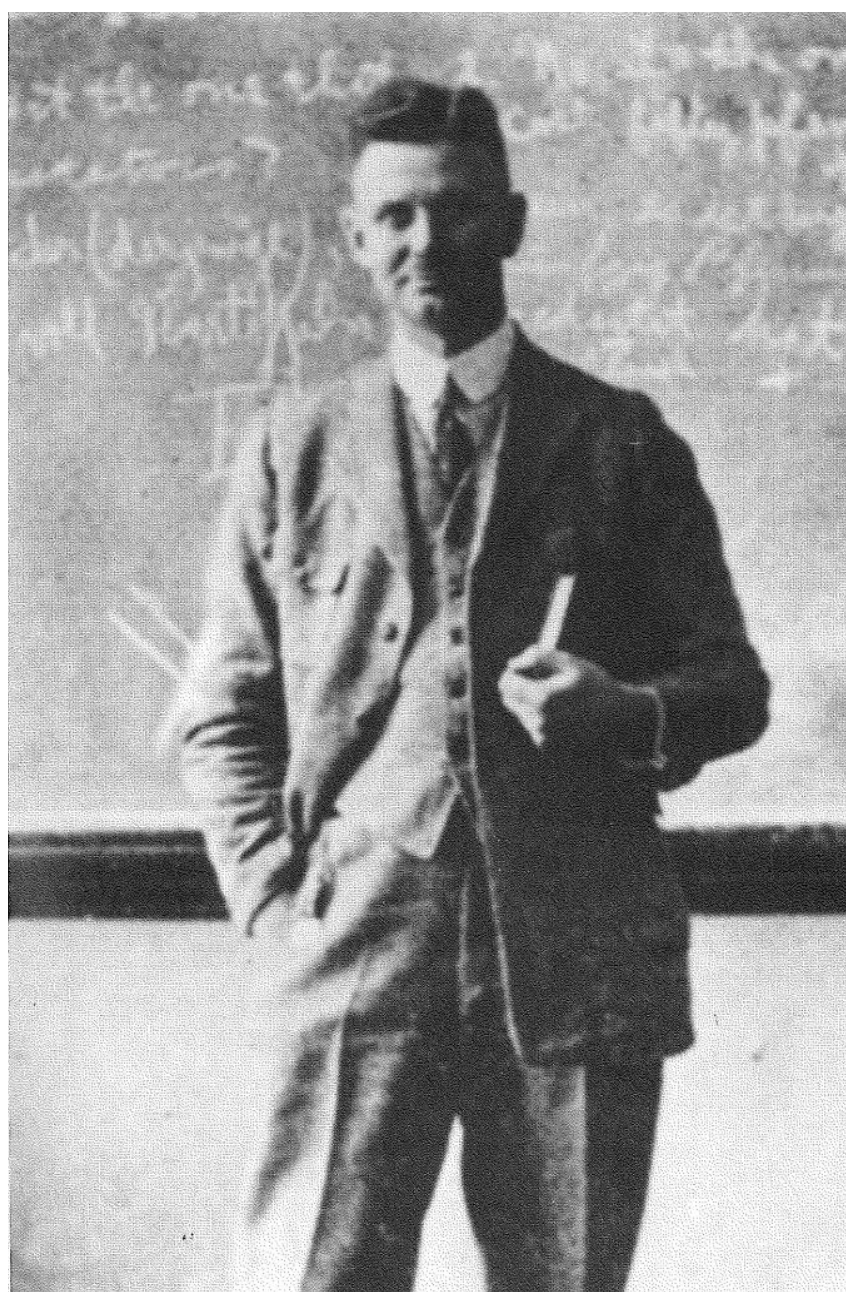


Appendix 5: Ted Hughes's and Sylvia Plath's selections of Ariel (emboldened where selections differ)

Plath's 1962 selection

Morning Song
The Couriers
The Rabbit Catcher
Thalidomide
The Applicant
Barren Woman
Lady Lazarus
Tulips
A Secret
The Jailer
Cut
Elm
The Night Dances
The Detective
Ariel
Death \& Co.
Magi
Lesbos
The Other
Stopped Dead

Poppies in October

The Courage of Shutting-Up

Nick and the Candlestick

Berck-Plage

Gulliver

Getting There

Medusa

Purdah

The Moon and the Yew Tree

A Birthday Present

Letter in November

Amnesiac

The Rival

Daddy

You're

Fever $103^{\circ}$

The Bee Meeting

The Arrival of the Bee Box

Stings

The Swarm

Wintering
Hughes's 1965 selection

Morning Song
The Couriers
Sheep in Fog
The Applicant
Lady Lazarus
Tulips
Cut
Elm
The Night Dances
Poppies in October
Berck-Plage
Ariel
Death \& Co.
Nick and the Candlestick
Gulliver
Getting There
Medusa
The Moon and the Yew Tree
A Birthday Present
Letter in November
The Rival
Daddy
You're
Fever 103
The Bee Meeting
The Arrival of the Bee Box
Stings
Wintering
The Hanging Man
Little Fugue
Years
The Munich Mannequins
Totem
Paralytic
Balloons
Poppies in July
Kindness
Contusion
Edge
Words




\section{Bibliography}

The following abbreviations have used throughout the text:

BL Hughes, Ted. Birthday Letters. London. Faber and Faber. 1998.

SPC Plath, Sylvia. Collected Poems. London: Faber and Faber. 1981.

THC Hughes, Ted. Collected Poems. London: Faber and Faber. 2003.

Aird, Eileen. Sylvia Plath: Her Life and Work. New York: Harper and Row, 1973.

Alexander, Paul. Rough Magic. Cambridge MA: Da Capo Press. 2003. [1991].

Alvarez, Al. 'Poetry in Extremis'. Observer. 19 March 1965. 26. In: Wagner, Linda W. (ed.) Sylvia Plath: The Critical Heritage. London: Routledge, 1988.

Alvarez, Al. The Savage God: A Study of Suicide. New York: Random House, 1971.

Alvarez, Al. The Writer's Voice. London: Bloomsbury Publishing. 2005.

Baring, Anne and Cashford, Jules. The Myth of the Goddess. New York: Viking, 1991.

Bassnett, Susan. "Plath Translated: Ted Hughes' Birthday Letters". Sylvia Plath: An Introduction to the Poetry. Hampshire: Palgrave Macmillan, 2005.

Becker, Jillian. Giving Up: The Last Days of Sylvia Plath. New York: Ferrington, 2002.

Bentley, Paul. The Poetry of Ted Hughes: Language, Illusion and Beyond. London: Longman, 1998.

Brain, Tracey 'Dangerous confessions: the problem of reading Sylvia Plath biographically'. In: Gill, Jo. Modern Confessional Writing. New York: Routledge, 2006.

Brown, Claire and Paterson, Don. Don't Ask Me What I Mean: Poets in their Own Words. London: Picador, 2003.

Brenan, Claire. The Poetry of Sylvia Plath: Icon Critical Guides. Cambridge: Icon Books, 1999. 
Bundtzen, Lynda. 'Mourning Eurydice: Ted Hughes as Orpheus in Birthday Letters.' Journal of Modern Literature 23.3. 2000

Bundtzen, Lynda. K. The Other Ariel. Massachusetts: Massachusetts Press, 2001.

Butscher, Edward. Sylvia Plath: Method and Madness. New York: Seabury Press, 1976.

Campbell, Joseph. The Masks of God: Primitive Mythology. New York: Penguin, 1976 [1959, 1969].

Doty, William G. Mythography: The Study of Myths and Rituals. Alabama: University of Alabama Press, 2000.

Dyson, A. E. 'Necessity and Freedom: The Poetry of Robert Lowell, Sylvia Plath, and Anne Sexton' Critical Quarterly. VII No. 1. 1965

Emory University Special Collection Archives. Ted Hughes Collection. Atlanta, Georgia, U.S.

Emory University Special Collection Archives. Seamus Heaney Collection. Atlanta Georgia, U.S.

Feinstein, Elaine. Ted Hughes: The Life of a Poet. New York: Norton, 2001.

Gifford, Terry and Neil Roberts' Ted Hughes: A Critical Study. London: Faber and Faber, 1981.

Gill, Jo. Modern Confessional Writing. New York: Routledge, 2006.

Gill, Jo. 'The Colossus and Crossing the Water'. The Cambridge Companion to Sylvia Plath. Cambridge: England, 2006.

Graves, Robert. The White Goddess: A Historical Grammar of Poetic Myth. New York: Farrar, Straus and Giroux, 2001 [1948].

Greer, Germaine in Close Up, BBC TV. December 1998.

Grolier Club Exhibition. New York. 'No Other Appetite: Ted Hughes, Sylvia Plath and the Blood Jet of Poetry’. 14 September - 19 November 2005.

Hardwick, Elizabeth. Seduction and Betrayal. London: Weidenfeld \& Nicholson, 1974.

Hayman, Ronald. The Life and Death of Sylvia Plath. London: William Heinemann, 1991. 
Hirschberg, Stuart. Myth in the Poetry of Ted Hughes. Totowa, New Jersey: Barnes and Noble Books, 1981.

Hughes, Frieda. 'Foreword'. In: Plath, Sylvia. Ariel: The Restored Edition. New York: Harper Collins, 2004.

Hughes, Olwyn. 'Reviewing Sylvia Plath' [In response to 'Sylvia Plath's Apotheosis' (24 June 1976)] The New York Review of Books. 30 September 1976. Vol. 23. 15.

Hughes, Ted. Alcestis. London: Faber and Faber, 1999.

Hughes, Ted. Aeschylus' Oresteia. London: Faber and Faber, 1999.

Hughes, Ted. Birthday Letters. London. Faber and Faber. 1998.

Hughes, Ted. 'The Burnt Fox'. Winter Pollen: Occasional Prose. London: Faber \& Faber, 1994.

Hughes, Ted. Cave Birds: An Alchemical Cave Drama. New York: Viking Press, 1978.

Hughes, Ted. (ed.) A Choice of Coleridge's Verse. London: Faber and Faber: London, 1996.

Hughes, Ted. Collected Poems. London: Faber and Faber. 2003

Hughes, Ted. CROW: From the Life and Songs of Crow . London: Faber and Faber, 1970.

Hughes, Ted. 'The Deadfall'. In: Morpurgo, Michael. (ed.) Ghostly Haunts. London: Pavilion Books, 1994.

Hughes, Ted. Difficulties of a Bridegroom. London: Faber and Faber, 1995.

Hughes, Ted. 'The Evolution of Sheep in Fog'. [1988]. Winter Pollen: Occasional Prose. Faber and Faber. London, 1994.

Hughes, Ted. Ffangs the Vampire Bat and the Kiss of Truth. London: Faber and Faber, 1986.

Hughes, Ted. (ed.) 'Foreword'. In: The Journals of Sylvia Plath. New York: The Dial Press, 1982.

Hughes, Ted. 'Keats on the Difference between the Dreamer and the Poet' [1986]. Winter Pollen: Occasional Prose. London: Faber \& Faber, 1994.

Hughes, Ted. Lupercal. London: Faber and Faber, 1960. 
Hughes, Ted. 'Myth and Education'. [1976] Winter Pollen: Occasional Prose. London: Faber, 1994.

Hughes, Ted. 'Notes on the Chronological Order of Sylvia Plath's Poems.' [1966]. In: Newman, Charles. The Art of Sylvia Plath. USA: Indiana University Press, 1971.

Hughes, Ted. 'Orpheus'. The Tiger's Bones and Other Plays for Children. New York: Viking. 1974.

Hughes, Ted. Poems Selected by Simon Armitage: Faber $80^{\text {th }}$ Anniversary Edition. London: Faber \& Faber, 2010.

Hughes, Ted. Poetry in the Making. London: Faber and Faber. 1967.

Hughes, Ted. 'Publishing Sylvia Plath'. [1971] Winter Pollen: Occasional Prose. London: Faber and Faber, 1994.

Hughes, Ted. 'Regenerations' (1964). Winter Pollen: Occasional Prose. London: Faber and Faber, 1994.

Hughes, Ted. Shakespeare and the Goddess of Complete Being. London: Faber, 1992.

Hughes, Ted. (ed.) 'Introduction: The Snake in the Oak'. A Choice of Coleridge's Verse. London: Faber, 1996.

Hughes, Ted. 'Sylvia Plath: Ariel'. [1965] Winter Pollen: Occasional Prose. London: Faber, 1994.

Hughes, Ted. 'Sylvia Plath's Collected Poems and The Bell Jar.' (1995). In: Scammell, William. (ed.) Hughes, Ted: Winter Pollen. New York: Picador. 1995.

Hughes, Ted. 'Sylvia Plath and her Journals'. [1982]. Winter Pollen: Occasional Prose. London: Faber and Faber., 1994.

Hughes, Ted. Tales from Ovid. London: Faber and Faber, 1997.

Hughes, Ted. Wodwo. London: Faber and Faber, 1967.

Hughes, Ted. The Wound. Transcript by Ann Skea of an interview with Ted Hughes at the Adelaide Festival, March 1976. Reproduced by permission of Radio National and the ABC (Australia). Available online at: http://www.zeta.org.au/ annskea/ABC2AF.htm

Hunter Steiner, Nancy. A Closer Look at Ariel: A Memory of Sylvia Plath. London: Faber and Faber, 1974. 
Hutton, James. Trans. Aristotle's Poetics. New York: W.W. Norton, 1982.

Jackson, Anna. 'Sylvia Plath's “Exaggerated American Grin”: Anti-American Sentiment and the Reception of Plath's Poetry'. Journal of Transatlantic Studies, 5(2) 2007.

Jung, C.G. Collected Works, Vol.5, Symbols of Transformation. London: Routledge, 1956. xxiv.

Kendall, Tim. Sylvia Plath: A Critical Study. London: Faber and Faber, 2001.

Koren, Yehuda and Negev, Eilat. A Lover of Unreason: The Life and Tragic Death of Assia Wevill. London: Robson Books, 2006.

Kroll, Judith. Chapters in a Mythology: The Poetry of Sylvia Plath. London: Harper \& Row, 1976.

Kroll, Judith 'Not a Conspiracy'. The New York Review of Books. Volume 24, No.8. 12 May 1977.

Kukil, Karen. Ed. The Journals of Sylvia Plath 1950-1962. London: Faber and Faber, 2000.

Lowell, Robert. 'Foreword'. In Plath, Sylvia. Ariel. New York: Harper \& Row. 1966.

Malcolm, Janet. The Silent Woman: Sylvia Plath and Ted Hughes. New York: Alfred A. Knopf, 1994.

Marsack, Robyn. Sylvia Plath. Buckingham: Open University Press, 1992.

Middlebrook, Diane. Her Husband: Ted Hughes and Sylvia Plath: A Marriage. London: Little Brown, 2004.

Middlebrook, Diane. 'Hughes, Plath, and the Three Caryatids'. Fixed Stars Govern a Life: Transforming Poetics and Memory with Emory's Ted Hughes Archive. Atlanta GA: The Academic Exchange, 2006.

Moses, Kate. Wintering. London: Hodder and Stoughton, 2003.

Newman, Charles. (ed.) The Art of Sylvia Plath. 'Sylvia Plath and Confessional Poetry' [M.L. Rosenthal]. London: Indiana University Press, 1971.

Newman, Charles. 'Candor is the Only Wile' [1966]. The Art of Sylvia Plath. USA: Indiana University Press, 1971.

Partenie, Catalin. Ed. Plato: Selected Myths. Oxford: Oxford World's Classics, 2004. 
Plath, Sylvia. Ariel. London: Faber and Faber. 1965.

Plath, Sylvia. Ariel: The Restored Edition. New York: Harper Collins, 2004.

Plath, Sylvia. The Bell Jar. New York: Harper and Row, 1996. [1962].

Plath, Sylvia. The Colossus. London: Faber and Faber, 1967. [1960]

Plath, Sylvia. Collected Poems. London: Faber and Faber, 1981.

Plath, Sylvia. Crossing the Water. London: Faber and Faber, 1971.

Plath, Sylvia. Letters Home. London: Faber \& Faber, 1976.

Plath, Sylvia. 'Ocean 1212-W' [1962]. Johnny Panic and the Bible of Dreams (and Other Prose Writings). London: Faber and Faber, 2001 [1977].

Plath, Sylvia. Winter Trees. London: Faber and Faber, 1971.

Pollitt, Katha. 'Peering Into the Bell Jar'. The New York Times. 1 March 1998.

Powell, Barry B. 'Myths of Death: Encounters with the Underworld'. Classical Myth. Fourth Edition. New Jersey: Pearson Prentice Hall, 2004.

Reid, Christopher. Letters of Ted Hughes. London: Faber and Faber, 2007

Roberts, Neil. Ted Hughes: A Literary Life. New York: Palgrave, 2006.

Rose, Jacqueline. The Haunting of Sylvia Plath. London: Virago Press, 1991.

Rosenthal, M.L. 'Poets of the Dangerous Way'. Spectator. 19 March 1965. 367. In: Wagner, Linda W. ed. Sylvia Plath: The Critical Heritage. London: Routledge, 1988.

Sagar, Keith. The Laughter of Foxes: A Study of Ted Hughes. $2^{\text {nd }}$ revised edition. Liverpool: Liverpool University Press, 2006.

Scigaj, Leonard. 'The Deterministic Ghost in the Machine of Birthday Letters'. In: Moulin, J. (ed.) Ted Hughes: Alternative Horizons. Taylor and Francis Group. London. 2004.

Skea, Ann. Poetry and Magic can be found at: http://ann.skea.com/BLCabala.htm.

Skea, Ann. The Poetic Quest. New England: University of New England Press, 1994.

Stallworthy, Jon. 'With Sorrow Doubled'. In: Gammage, Nick. The Epic Poise: A Celebration of Ted Hughes. London: Faber and Faber, 1999. 
Stevenson, Anne. Bitter Fame: A Life of Sylvia Plath. Boston: Houghton Mifflin Co. 1989.

Tennant, Emma. Burnt Diaries. Edinburgh: Canongate Books, 1999.

Tennant, Emma. Sylvia and Ted: A Novel. Australia: Flamingo, 2001.

Unsigned Review. 'Along the Edge'. Times Literary Supplement. 25 November 1965, 701. In: Wagner, Linda W. ed. Sylvia Plath: The Critical Heritage. London: Routledge, 1988.

Uroff, Margaret Dickie. Sylvia Plath and Ted Hughes. Chicago: University of Illinois Press, 1979.

Wagner, Erica. Ariel's Gift: Ted Hughes, Sylvia Plath and the Story of the Birthday Letters. London: Faber, 2000.

Van Dyne, Susan R. 'The problem of biography'. In: Gill, Jo. Ed. The Cambridge Companion to Sylvia Plath. Cambridge: Cambridge University Press, 2006.

Wagner-Martin, Linda W. Sylvia Plath: A Biography. London: Chatto \& Windus, 1987.

Wagner-Martin, Linda W. (ed.) Sylvia Plath: The Critical Heritage. London: Routledge, 1988.

Wood, James. 'Muck Funnel: Birthday Letters by Ted Hughes'. The New Republic. Mar. $30,1998$. 